\title{
Faunas from Atapuerca at the Early-Middle Pleistocene limit: the ungulates from level TD8 in the context of climatic change
}

\author{
Jan van der Made \\ Museo Nacional de Ciencias Naturales, CSIC, c. José Gutiérrez Abascal 2, 28006 Madrid, España. \\ mcnjv538@mncn.csic.es \\ Jordi Rosell \\ Àrea de Prehistoria, Universitat Rovira I Virgili (URV), Avinguda de Catalunya 35, 43002 Tarragona, Spain. \\ IPHES, Institut Català de Paleoecologia Humana I Evolució Social, C/ Marcel.lí Domingo s/n - Campus \\ Sescelades URV (Edifici W3), 43007 Tarragona, Spain. jordi.rosell@urv.cat

\section{Ruth Blasco} \\ Departament de Prehistòria, Universitat Autònoma de Barcelona, Facultat de Lletres-Edifici B,08193 Bellaterra, \\ Barcelona, Spain. rblascolopez@gmail.com
}

\begin{abstract}
An extraordinary sequence of fossiliferous levels at the locality of Gran Dolina in the Atapuerca Hills (Burgos, Spain) records the Early-Middle Pleistocene transition. These levels are well dated by a variety of methods, including palaeomagnetism, which locates Lower-Middle Pleistocene boundary at the tope of level TD7. Level TD6 is the type site of the species Homo antecessor and yielded over 90\% of the European Early Pleistocene human record, while other levels have an archaeological record. The present paper deals with the earliest Middle Pleistocene ungulates of TD8, but we plan to describe the faunas, or at least the ungulates, of levels TD4 to TD8 in the context of the faunal changes that took place around the Early-Middle Pleistocene transition.

About 600 fossils could be assigned to a taxon and on this basis the following ungulates are described from TD8: horse Equus altidens, rhinoceros Stephanorhinus aff. etruscus, wild boar Sus scrofa, hippopotamus Hippopotamus sp., red deer Cervus elaphus, giant deer Eucladoceros aff. giulii, giant deer Megaceroides solilhacus, fallow deer Dama vallonnetensis, and bison Bison voigtstedtensis. The evolution of these taxa is discussed. The fauna from level TD8 dates to the earliest Middle Pleistocene (stage 19) and differs from later faunas in the retention of a small rhinoceros (Stephanorhinus aff. etruscus) and the latest representative of the genus Eucladoceros. It differs from earlier faunas in having the striped hyaena. Together with the fauna from TD7, in which the Brunhes-Matuyama boundary is recorded, TD8 will provide the most precise criterions for correlation of the Early-Middle Pleistocene boundary on the basis of fossils of large mammals.

Profound changes in the global climate system started to take place during the late Early Pleistocene, leading to intensive environmental and faunal change and to human dispersal into Europe. These events mark the beginning of a new time and the Early-Middle Pleistocene boundary is taken somewhere in the middle of this drawn out process. It is taken at a palaeomagnetic change, which is convenient, but this does not appear to be close to an important climatic or faunal change. Ten faunal events are recognized in the period from about 1.2 to 0.5 Ma. The event closest to the Early-Middle Pleistocene boundary is one of the minor events and up to now it is recorded in only few localities, principally in TD8.
\end{abstract}

\section{INTRODUCTION}

The sequence of Gran Dolina covers the uppermost part of the Lower Pleistocene, records the Lower-Middle Pleistocene limit and covers the lowermost part of the Middle Pleistocene. These rock units correspond to a very interesting time.

It has been known since long that towards the end of the Early Pleistocene great changes in the fauna took place, but what, when, where, how and why is not exactly known. Azzaroli (1983) believed this to be a single event, which happened between 1.0 and 0.9 Ma in all Eurasia, and called it the "End-Villafranchian Dispersal Event”. This name or variants of it are still often applied. However, there is not a single dispersal event, but an increase in the frequency of dispersals into Europe, which was maintained during the whole Middle Pleistocene (e.g. Van der Made, 2011a). Also many extinctions occurred and species evolved into other species. A biogeographic novelty of major importance was that after 1-0.9 Ma there was a cyclic alternation in mid-latitude Europe and Asia of glacial and interglacial faunas. On a large scale, European species longevity decreased and the rates of evolution increased markedly as well as turnover corrected for species richness, while this did not happen the same way in Africa (Van der Made, 2014). This pattern of increasing change happened probably the same all over northern Eurasia, but probably not in low-latitude Asia. It is reflected in the transition of the continental stage Villafranchian to the Galerian or Cromerian, the transition period also being called "EpiVillafranchian” (R.D. Kahlke, 2007; Bellucci et al., 2014-on line). Part of all these events, is the dispersal of the 


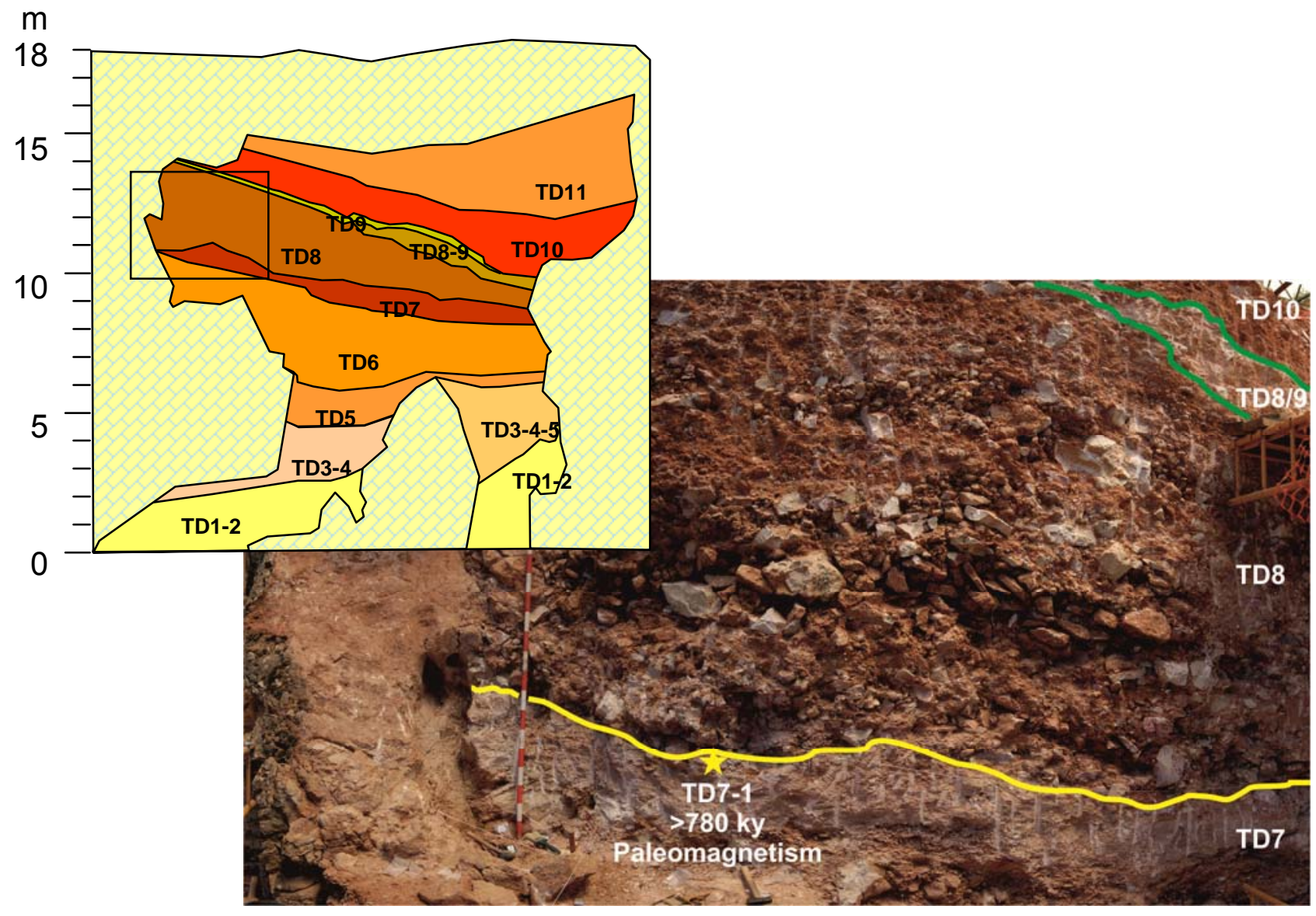

\section{Figure 1}

Schematic section of Gran Dolina and photograph of TD8 and the top of TD7, indicating the approximate level of the Brunhes Matuyama Boundary. 


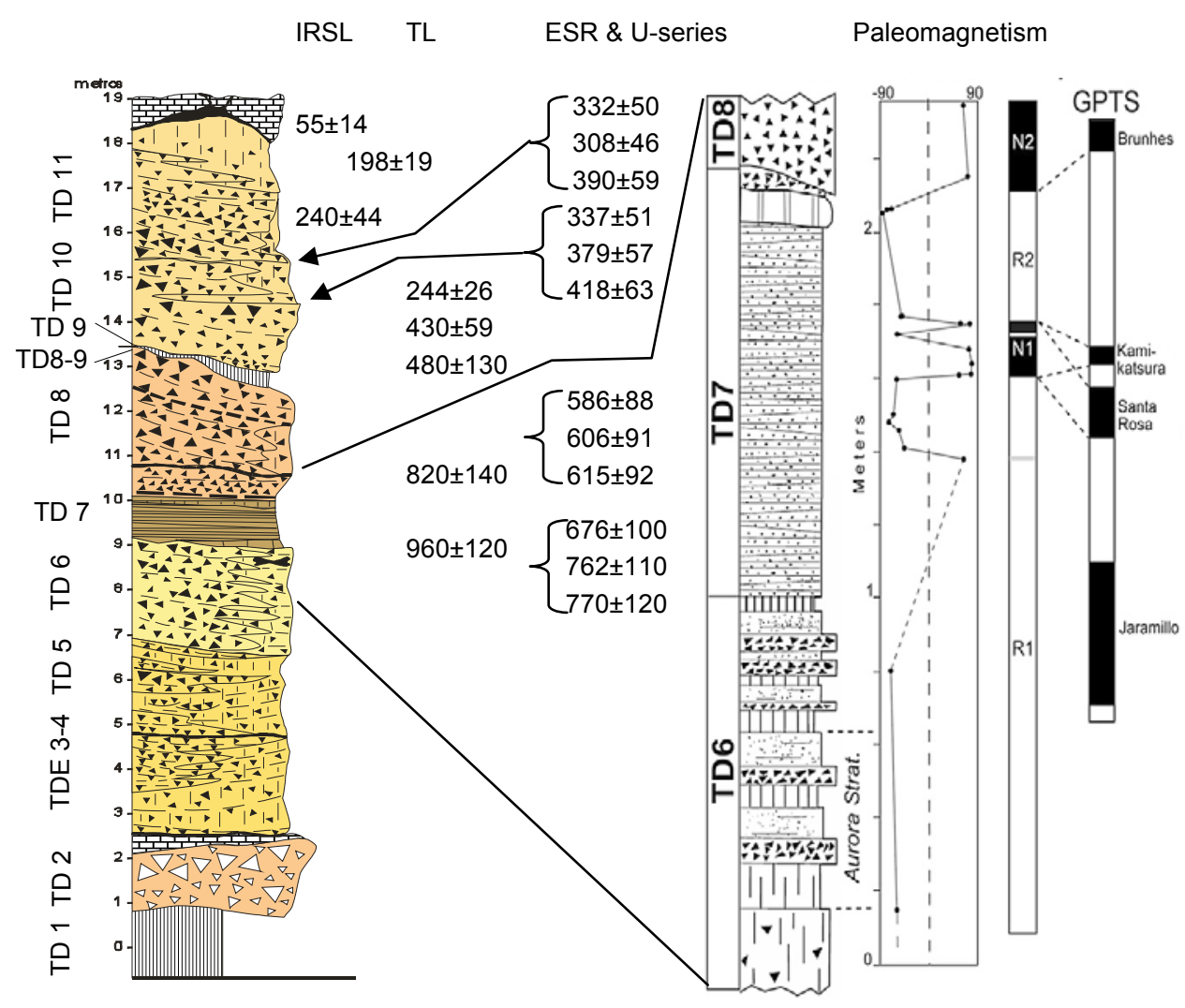

Figure 2

Lithostratigraphic section of Gran Dolina with amplification of TD6-8 to show the Brunhes-Matuyama boundary and normal events within TD7, as well as the IRSL, TL and ESR and U-sieres dates. After Berger et al. (2008) and Parés et al. (2013). 
genus Homo to Europe.

This faunal turnover was caused by environmental change, induced by modifications in the global climatic system, which in turn resulted from astronomic changes. The different Milankovich cycles, with durations of about 20, 40 and 100 ky have a major impact on global climate. Before about 1.2-0.9 Ma, the $40 \mathrm{ky}$ obliquity cycle was the one that had most influence on global climate, but in this time lapse, the $100 \mathrm{ky}$ eccentricity cycle became more prominent, leading to the well known alternation of glacial and interglacial periods (deMenocal, 1995; Shackleton, 1995). The period after these changes occurred is markedly different in climate, flora and fauna. More or less this difference is reflected in the subdivision of the Pleistocene into Early and Middle + Late Pleistocene. However, the Early-Middle Pleistocene boundary was conveniently chosen to coincide with the Brunhes Matuyama boundary, which objectively can be recognized around the globe, but does not coincide exactly with the most important climatic or biotic events.

The different archaeological and paleontological localities and levels in the Atapuerca Hills (Sierra de Atapuerca) range in age from about 1.2 Ma till recent, with an important concentration between about 1.2 and $0.75 \mathrm{Ma}$, The locality of Sima del Elefante has fossiliferous levels TE7 to TE14 with ages between 1.2 and 1.07 Ma, Gran Dolina has fossiliferous levels TD4 to TD8 with ages between 0.99 and about $0.75 \mathrm{Ma}$, and the locality of Penal is in approximately the same time range (Rodríguez et al., 2011). For the study of the late Early Pleistocene faunal events, such a paleontological sequence is unique in Europe. It is also unique for another reason.

As stated above, human dispersal to Europe formed part of these late Early Pleistocene events. Nearly all these levels in the sites in the Atapuerca Hills have also an archaeological record and some have human fossils. With at present 160 human fossils recovered, level TD6 has over 90\% of the European Early Pleistocene human record, while the remaining specimens are from Sima del Elefante TE9, Cueva Negra, and Barranco León, while there are also remains from Cueva Victoria and Venta Micena, which are disputed (Carbonell et al., 2008; Walker et al., 2006; Toro-Moyano et al., 2013; Gibert et al., 1998, 1999, 2008). The human species Homo antecessor was defined on the basis of fossils from TD6 (Bermúdez de Castro et al., 1997). The human fossils and archaeological record of Atapuerca played a decisive role in the debate on early human occupation of Europe. In addition, Gran Dolina, Sima del Elefante, Galería and Sima de los Huesos have also middle Middle Pleistocene younger levels with an important paleontological, archaeological and paleoanthropological record..

The karstic locality of Gran Dolina is situated in an abandoned railway trench that was cut through the hill. This trench exposes nearly 20 metres of its sediments, while there are still many more metres below the bottom of the trench. The exposed stratigraphic units are numbered from bottom till top from TD 1 to TD 12 . In TD, $\mathrm{T}$ stands for Trinchera (= trench) and D for Dolina. In a similar way TE = Sima del Elefante, TP = Penal, and TG = Galería. Due to the shape of the cavity and the position of the railway trench, level TD4 is exposed out at two sides of a rock, one side is called TDW4 and the other TDE4; the precise stratigraphic relationship between both sides is not yet exactly clear. Unit TD 2 is said to have yielded some and TD3 many fossils (Soto, 1987). These units have been excavated in the nineteen seventies, and at present they cannot well be recognized. In the present situation fossils come from levels TD4 to TD8 and from TD10. In the early nineteen nineties, there have been excavations in TDW4. A test pit of about $6 \mathrm{~m}^{2}$ was excavated through all levels, reaching TD8 in 1994. The front of the locality was very irregular and was subsequently straightened, to avoid collapse. Material from TD8 was recovered from 2002 till 2006. The concept of TD8 has changed. Originally, it was considered to consist of two subunits: TD8a, with fossils of small and large mammals, which is overlain by TD8b, with only small mammals. Now TD8b is considered a separate unit, called TD8-9 and TD8a is called simply TD8 (Rodríguez al., 2011, table 2). In the near future, excavations are planned in a relatively extensive area of TD4 at the base of the locality.

It is the aim of this paper to describe the fauna from TD8, or at least the ungulates, within the context of the faunal change around the Early - Middle Pleistocene transition. It is also an aim, to do the same in future papers for the faunas from levels TD7 to TD4. In this paper, a scheme of late Early and early Middle Pleistocene faunal change is presented. The same scheme will be used and improved in the future papers.

\section{MATERIAL AND METHODS}

The fossils described here are presently kept in the IPHES, but the final repository will be the CENIEH (see acronyms below). The labels of the specimens indicate first “Ata” for Atapuerca and the year, then the locality (TD for Gran Dolina) and the level and in some cases the sublevel, the square (a letter and a number), and finally the specimen number. Specimen numbers are within a square and level and start each year again from 1 . In the test pit, spit numbers were recorded as t (= talla = spit). A complete number is: Ata06, TD8B, G-4, 145.

In about 600 specimens from Atapuerca TD8 relevant morphology could be observed or standard measurements could be taken. The specimens studied are indicated under each species or in the tables of 
measurements in the supplemental information. When these fossils are compared to fossils and bones and teeth of recent animals, either a bibliographic reference or an acronym is given for the institute where the material was studied or where it is presently kept:

AHAPMR Azov Historical, Archeological and Paleontological Museum-Reserve, Azov.

AUT

AVP

CENIEH

CIAG

DGFSUPV

DSTUSR

EBD

ETSI

FBFSUJ

FISF

GIN

GSM

HGSB

HMV

HUJ

IGF

IPH

IPHES

IPRFWUB

IPUW

IQW

LPTUP

LVH

MAC

MAN

MAR

$\mathrm{MB}$

MCP

MHMV

MNB

MNCN

Monrepos

MSI

MUB

NBC

NCM

NCUA

NHM

NMM

NMMaa

NMP

NMW

MPRM

PIMUZ

PIN

SIAP

SMNK

SMNS

SMS

TMH

TUC

UCBL
Aristotle University of Thessaloniki.

Accademia Valdarnese del Poggio, Montevarchi.

Centro Nacional de Investigación sobre la Evolución Humana, Burgos.

Centre d'Investigacions Arquelògics de Girona.

Departamento de Geología, Facultad de Ciencias, Universidad del País Vasco, Bilbao.

Dipartimento di Scienze della Terra, Università "La Sapienza", Roma.

Estación Biológica de la Doñana, Sevilla.

Escuela Tecnica Superior de Ingenieros de Minas y Energía de la Universidad Politecnica de Madrid.

Forschungstelle Bilzingsleben, Friedrich Schiller-Universität Jena, Bilzingsleben.

Forschungsinstitut Senckenberg, Frankfurt.

Geological Institute, Moscow.

Georgian State Museum, Tbilisi.

Hungarian Geological Survey, Budapest.

Historisches Museum, Verden.

Hebrew University, Jerusalem.

Istituto di Geologia, now Museo di Storia Naturale, Firenze.

Institut de Paléontologie Humaine, Paris.

Institut Català de Paleoecologia Humana I Evolució Social, Tarragona.

Institut für Paläontologie der Rheinischen Friedrich-Wilhelms Universität Bonn.

Institut für Paläontologie der Universität, Wien (Vienna).

Institut für Quartärpaläontologie, Weimar.

Laboratoire de Prehistoire de Tautavel, Université de Perpignan.

Landesmuseum für Vorgeschichte, Halle.

Museo de Arqueología de Cartagena.

Museo Arqueológico Nacional, Madrid.

Museo Arqueológico Regional, Alcalá de Henares.

Museo de Burgos, Burgos.

Musée Crozatier, Le Puy-en-Velay.

Museo Histrórico Municipal de Villamartin.

Museum für Naturkunde der Humboldt-Universität, Berlin.

Museo Nacional de Ciencias Naturales, Madrid.

Römisch-Germanisisches Zentralmuseum, Forschungsinstitut für Vor- und Frühgeschichte, Forschungsbereich Altsteinzeit Schloss Monrepos, Neuwied.

Museo de San Isidro, Madrid.

Medical University, Baku.

Naturalis Biodiversity Center, Leiden (previously Nationaal Natuurhistorisch Museum).

Norwich Castle Museum, Norwich.

National and Capodistrian University of Athens.

Natural History Museum, London.

Naturhistorisches Museum, Mainz.

Natuurhistorisch Museum, Maastricht.

National Museum, Prague.

Naturhistorisches Museum, Wien (Vienna).

Musée de Préhistoire Régionale, Menton.

Paläontologisches Institut und Museum der Universität, Zürich.

Palaeontological Institute, Moscow.

Servei d'Investigacions Arqueològiques I Prehistòriques, Castellón.

Staatliches Museum für Naturkunde, Karlsruhe.

Staatliches Museum für Naturkunde, Stuttgart.

Spengler Museum, Sangershausen.

Teylers Museum, Haarlem.

Technische Universität Clausthal, Insitut für Geologie und Paläontologie.

Université Claude Bernard, Lyon. 
UCM Universidad Complutense, Madrid.

VMM Vernadzki Museum, Moscow.

ZMA Zoölogisch Museum, Amsterdam; presently transferred to NBC.

ZPALUWr Division of Palaeozoology, Department of Evolutionary Biology and Ecology, University of Wroclaw.

The way of measuring and nomenclature for the Equidae are after Eisenmann et al. (1988). These authors number the measurements; addition to these numbers also the acronyms are given, which are generally applied here. The nomenclature and way of measuring for the Rhinocerotidae is after Van der Made (2010). Tooth nomenclature for the Artiodactyla is after Van der Made (1996). The way of measuring the teeth of the Suiformes and the bones of the Artiodactyla is generally after Van der Made (1996). Bovid and cervid metapodials and teeth are measured after Van der Made \& Tong (2008) and Van der Made (1989, 2012).

The following acronyms and names are used for the measurements in the figures and tables:

buckle DAP of the "double knot” or buckle in the lower molar of Equus

DAP Antero-posterior diameter

DLL Labio-lingual diameter

DMD Mesio-distal diameter in incisors

DT Transverse diameter, width

fossid $1 / 2 \quad$ DAP of the first and second fossid in the lower cheek teeth of Equus

$\mathrm{H} \quad$ Height

h An alternative measurement for the height

L Length

l An alternative measurement of length

protocone DAP of the protocone in an upper cheek tooth of Equus

$\mathrm{P}$ index $\quad$ Protoconal index $=100 \mathrm{x}$ protocone $/ \mathrm{DAP}$

plis $\quad$ Folds of the enamel in the upper cheek tooth of Equus

$\mathrm{R} \quad$ A diameter (as in R1, R2, ... of the humerus)

$\mathrm{T} \quad$ Enamel thickness

The position of these measurements is indicated by lower case letters, as in DTa or DTp:

of the anterior lobe of a tooth, at the anterior side of a bone

at the crown base

$\begin{array}{ll}\text { bu } & \text { at the buccal side of a tooth } \\ \text { d } & \text { at the distal or dorsal side }\end{array}$

dors at the dorsal side

ext at the lateral side

$\mathrm{f} \quad$ of the facet (as in DTdf = DT of the distal facet)

fa, fast of the facet for the astragalus

fp of the articular facet for the patella (in the femur)

$\mathrm{h} \quad$ of the head of a bone

int at the medial side

1 of the lower part of a bone

la at the labial side of a tooth

li at the lingual side of a tooth

$\mathrm{m} \quad$ in the middle

$\operatorname{maxi} / \max \quad$ maximal

mini minimal

n of the "neck" of a bone

o at the occlusal surface

$\mathrm{p} \quad$ of the posterior lobe of a tooth, of the proximal part of a bone

pp of the third lobe of an $\mathrm{M}_{3}$

root of the root of a tooth

sf at the level of the sustentacular facet in a calcaneum

$\mathrm{u} \quad$ of the upper part of a bone

III of the third digit, "anatomical length" at the medial side of a canon bone

IV of the fourth digit, "anatomical length” at the lateral side of a canon bone an alternative measurement

Phalanges, isolated distal articulations of metapodials and sesamoids of artiodactyls are similar in the third and fourth digit, and cannot be separated. In the tables, these are indicated as left or right ("l" or "r"), with reference to the axis of the manus or pes. Other bones are indicated as being "s" or "d" (sinistralis, dextralis). 
A third metacarpal of Equus is broken at the distal end and length (L), medial length (Lm), distal width above the articulation (DTd), nor distal articular width (DTdf) could be measured. These are the standard measurements 1, 2, 10 and 11 of Eisenmann et al. (1988). However, this is an important bone for equid systematics. In order to be able to make the relevant metric comparisons, the length and distal articular width were estimated, using regressions of lateral length $(\mathrm{Ll}=244.9$ in the specimen from TD8) and length $(\mathrm{Ll}=$ $\left.0.9978 \mathrm{~L}+7.4477, \mathrm{R}^{2}=0.9829, \mathrm{n}=50\right)$ and proximal width $(\mathrm{DTp})$ against DTdf (DTdf $=0.8976 \mathrm{DTp}-0.1155, \mathrm{R}^{2}$ $=0.8784, \mathrm{n}=66$ ), using data of several other species, giving the following results: $\mathrm{L}=251.8$ and DTdf=46.6. These values have been used in the metric comparisons and are indicated in Table 3. A similar procedure was followed to estimate the distal articular width (DTdf) from the width from the articulation with the fourth digit $\left(\mathrm{DT}_{\mathrm{IV}}\right)$ of a metacarpal of Dama $\left(\mathrm{DTdf}=2.1936 \mathrm{DT}_{\mathrm{IV}}-0.1862 ; \mathrm{R}^{2}=0.9959, \mathrm{n}=255\right)$. The result $\mathrm{DTdf}=32.9$ is indicated in Table 21.

\section{SYSTEMATICS}

\subsection{Horse}

Order Perissodactyla Owen, 1848

Family Equidae Gray, 1821

Genus Equus Linnaeus, 1758

Equus altidens Von Reichenau, 1915

\subsubsection{Material}

All material studied here is indicated in Tables 1-5 (supplementary data). Numbers Ata94, TD8, t28, G16, 44 and Ata94, TD8, t28, G17, 10 were used (destroyed) for dating (Falguères et al., 1999). A taphonomic study assigned 125 fossils to the horse, representing a minimum of 6 individuals (Rosell, et al., 2010).

\subsubsection{Description and comparison}

The lower molars, premolars and deciduous molars have V-shaped linguaflexids, as is typical of the "stenonid" species of Equus, while the "caballoid” species have U-shaped linguaflexids. Two lower molars fit together and apparently are the $\mathrm{M}_{1}$ and $\mathrm{M}_{2}$ of the same individual (Figures 3/2 and 3/3). The ectoflexid in the molars may or not enter the "isthmus" between the pre- and postflexid (fossid). There is no clear pli-caballinid, but the hypocones are angled at that place.

The $\mathbf{M}^{1 / 2}$ and $\mathbf{P}^{3 / 4}$ (Figure 3/1) have small protocones. There is a slight constriction anterior to the hypocone. The para- and mesostyles are rounded and do not have a groove. The protocone is small, roughly triangular and its lingual side is slightly convex.

Metric comparisons have been made for the upper cheek teeth. The protoconal indices have relatively low values (PI in the upper diagrams in Figure 2), as is common in most fossil non caballoid species, while the values are higher in fossil and recent caballoid horses and in the recent hemiones. Equus hydruntinus seems to be intermediate in this respect. The sizes of the cheek teeth vary relatively little between the different species and the sizes from TD8 are compatible with most, save for the largest and smallest species.

The third metacarpal (Mc III; Figure 4) is slender. Figure 4 (left graph) shows that caballoid species tend to have robust metacarpals, while a group of species, including E. wuesti, E. nalaikhensis, E. altidens, E. petraloniensis, E. hydruntinus and E. hemionus, have slender metacarpals. The specimen from TD8 clusters with the latter group. Equus suessenbornensis is intermediate, but is much larger. The specimen from TD8 is close to those of E. altidens, E. wuesti and E. nalaikhensis, and is larger than those of the other slender species. Figure 4 (right graph) shows another comparison, with various subspecies or samples of Equus stenonis and of a group of samples, most of which have either been attributed to E. stenonis, E. altidens or E. cf. tabeti (Alberdi \& Palombo, 2013; Steensma, 1988; Eisenmann, 1986), and which is intermediate between E. altidens and $E$. stenonis. The specimen from TD8 is much more slender than those of E. stenonis, but is close to the largest and most slender specimens of the intermediate group, and it is close to E. altidens.

The first phalanx (Figure 6) is relatively gracile. It is to be expected that the differences in proportions, which are noted in the metacarpals, are also seen to some extend in the phalanx. Similar comparisons have been made as in the metacarpal (Figure 5), and indeed the same patterns of gracile and robust forms is seen, but the separation is somewhat less clear. In part, this is possibly due to the mixing of anterior and posterior phalanges. However, separating phalanges in anterior or posterior, is likely to use robustness as a criterion, with some danger of circle reasoning, if later the results are used for intraspecific comparisons. In any case, for Equus altidens the anterior and posterior specimens are given separately. The specimen from TD8 is more gracile than the phalanges of the caballoid horses, E. stenonis and E. suessenbornensis, it is close to those of E. nailakhensis 


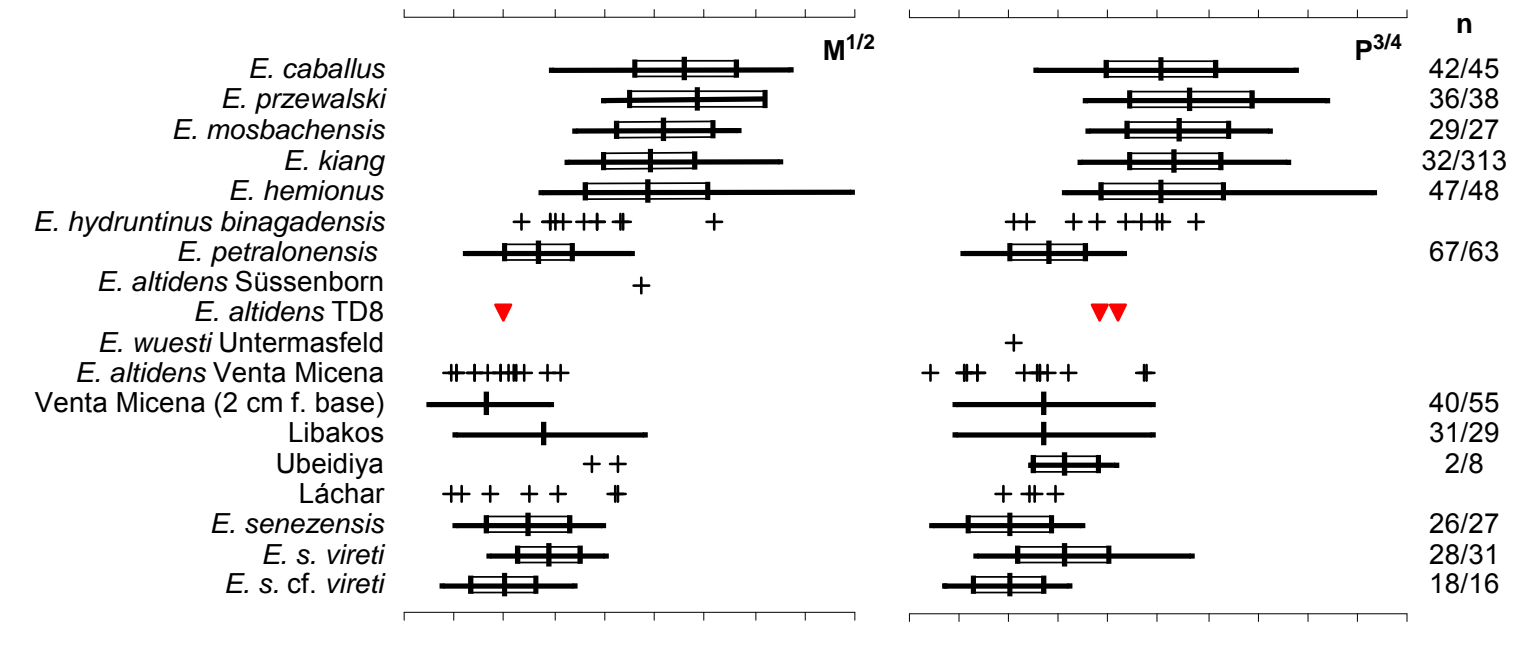

$\begin{array}{lllllllllllllllllllll}25 & 30 & 35 & 40 & 45 & 50 & 55 & 60 & 65 & \text { PI } & 20 & 25 & 30 & 35 & 40 & 45 & 50 & 55 & 60 & 65 & \text { PI }\end{array}$

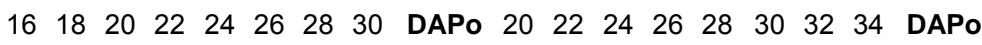

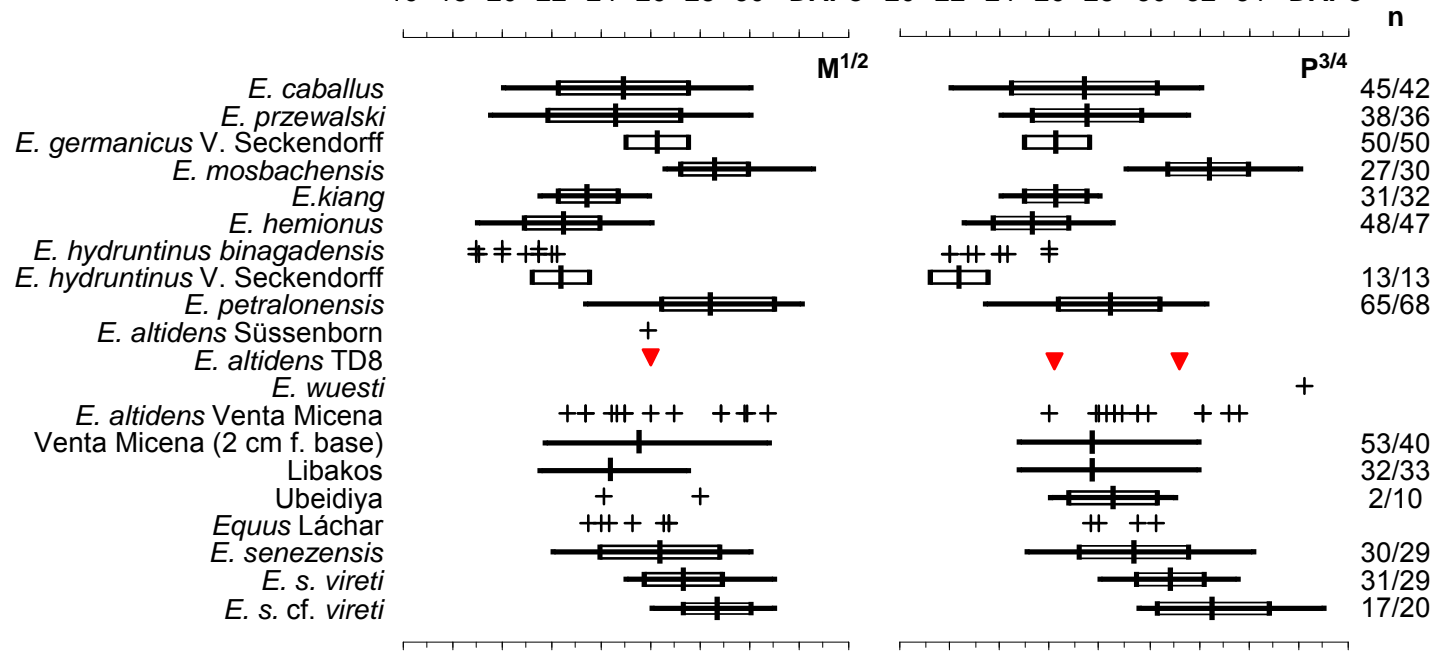


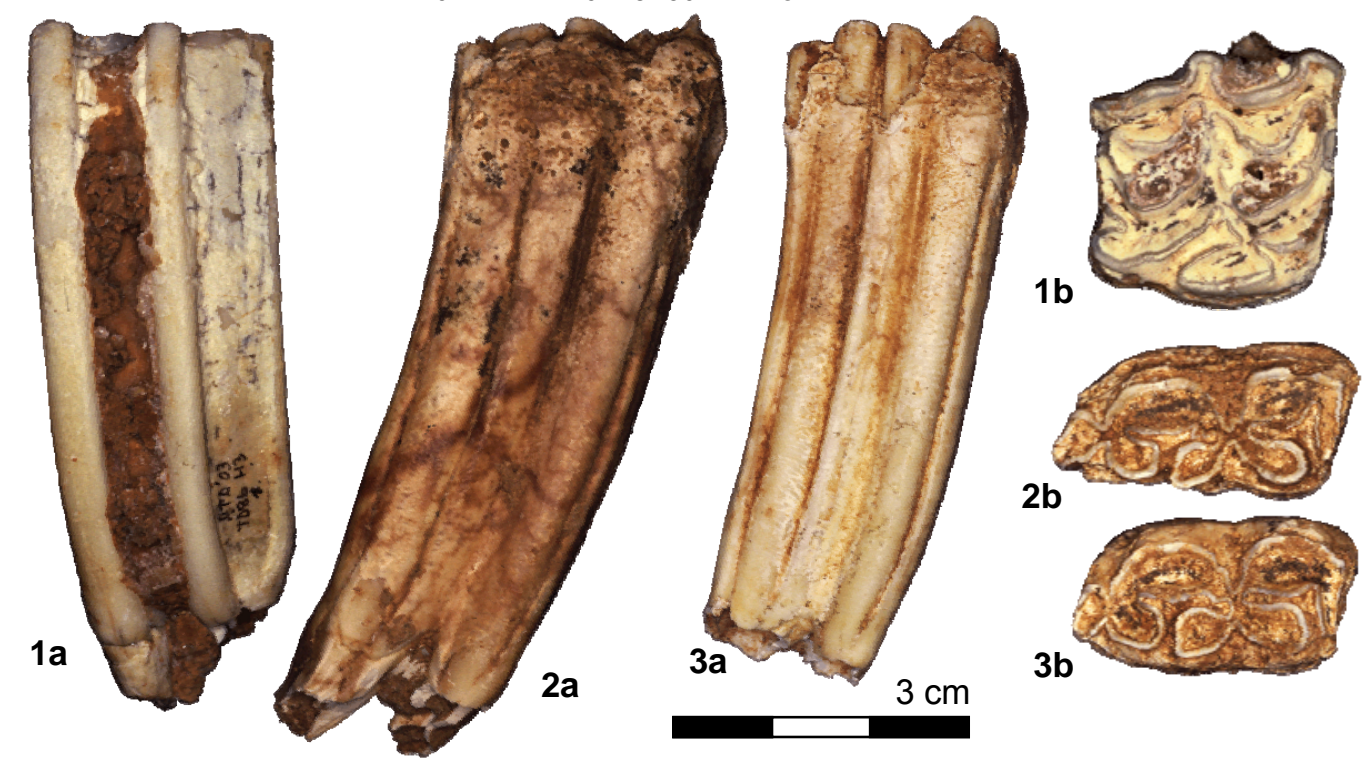

Figure 3

Equus altidens from Atapuerca TD8: 1) Ata03, TD8B, H3, 1 - right P3/4: a) buccal, and b) occlusal views. 2) Ata03, TD8B, G-6, 18 - left M2: a) lingual, and b) occlusal views. Ata03, TD8B, G-6, 17 - left M1: a) lingual, and b) occlusal views.

Diagrams showing the occlusal length (DAPo) and protoconal index (PI) of the M1/2 and P3/4 of Equus altidens from Atapuerca TD8 compared to selected samples and species of Equus. Provenance of data: E. caballus, E. przewalskii, E. mosbachensis, E. kiang, E. hemionus, E. stenonis senezensis, E. stenonis vireti, E. stenonis cf. vireti (all from Eisenmann, 1979), E. germanicus and E. hydruntinus from Villa Seckendorff (Forsten \& Ziegler, 1995), E. hydruntinus binagadiensis from Binagady (Eisenmann \& Kuznetsova, 2004), E. petraloniensis from Petralona (Tsoukala, 1989), E. wuesti from Untermassfeld (Musil, 2001), Equus altidens from Venta Micena (Marín, 1987; also the larger sample measured near the crown base is included), Equus sp. from Libakos (Steensma, 1988), Ubeidiya (Eisenmann, 1986), and Equus sp. from Láchar (Alberdi \& Ruiz-Bustos, 1987). 

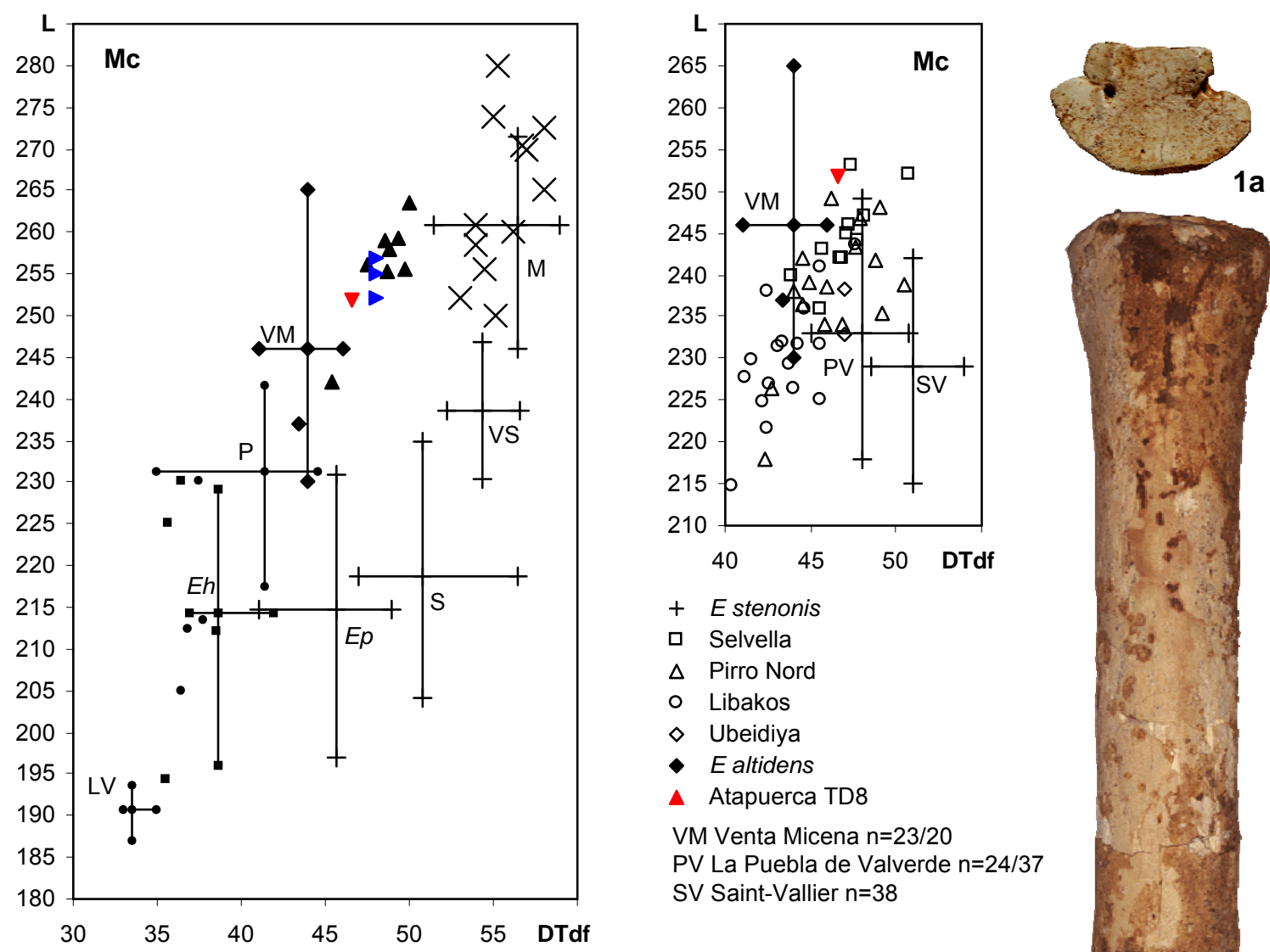

E stenonis

口 Selvella

$\triangle$ Pirro Nord

- Libakos

$\diamond$ Ubeidiya

- E altidens

- Atapuerca TD8

$V M$ Venta Micena $n=23 / 20$

PV La Puebla de Valverde $n=24 / 37$ SV Saint-Vallier $\mathrm{n}=38$

- E nalaikhensis

- E wuesti

- E altidens

$\checkmark$ TD8

- E hemionus

- E hydruntinus/petralonensis

$\times$ E suessenbornensis

+ Caballoid Equus

VM Venta Micena $n=23 / 20$

P Petralona $n=10 / 23$

Eh recent $\mathrm{n}=22$

LV Lunel Viel $n=8 / 10$

M Mosbach $n=39 / 27$

VS Vila Seckendorfff $n=34 / 38$

$S$ Solutré $n=81$

Ep recent $\mathrm{n}=17$



\section{Figure 4}

The third metacarpal (Mc III) of Equus altidens from Atapuerca TD 8: Ata2002, TD8B, G-10, 35 - right third metacarpal from TD8: 1a) proximal view, 1b) anterior view.

Bivariate diagrams of the distal articular width (DTdf) and length (L) of the third metacarpal comparing a specimen from Atapuerca TD8 to those of selected Equidae. The upper diagram shows the presence of two well defined groups with robust and gracile metapodials. Provenance of data: robust caballoid Equus from Villa Seckendorff (Forsten \& Ziegler, 1995), Solutré (Prat, 1980), and Mosbach and E. przewalskii (Eisenmann, 1979); gracile E. wuesti from Untermassfeld (Musil, 2001), E. nalakhensis from Nalaikha (Eisenmann \& Kuznetsova, 2004), E. altidens from Venta Micena (Marín, 1987) and Süssenborn (isolated specimen; Musil, 1969), E. petraloniensis from Petralona (Tsoukala, 1989), E. minor from Lunel Viel (LV) and E. hydruntinus from Lunel Viel and Binagady (isolated specimens) (both Eisenmann \& Mashkour 1999); and the intermediate $E$. suessenbornensis from Süssenborn (Musil, 1969), Ceyssaguet (Prat, 1980), Nalaikha (Eisenmann \& Kuznetsova 2004) and Semibalki (AHAPMR).

The lower diagram shows a series of samples that show a transition from robust to gracile: $E$. stenonis vireti from Saint Vallier and E. s. cf. vireti from La Puebla de Valverde (Eisenmann, 1979), Equus sp. from Ubeidiya (Eisenmann, 1986), Pirro Nord and Selvella (Alberdi \& Palombo, 2013), and Libakos (TUC), and E. altidens from Venta Micena (Marín, 1987). 




\section{Figure 5}

The robusticity (100 L/DTdf; average values only) and distal width of the articular surface (DTdf; average and range) of the third metacarpal (Mc III) in the smaller stenonid horses. Provenance of data as in the previous figure and, in addition, from Forstén (1999) and Steensma (1988). The chronologic distribution of the European Pleistocene Equidae; systematics largely after Forstén (1999). 



1b

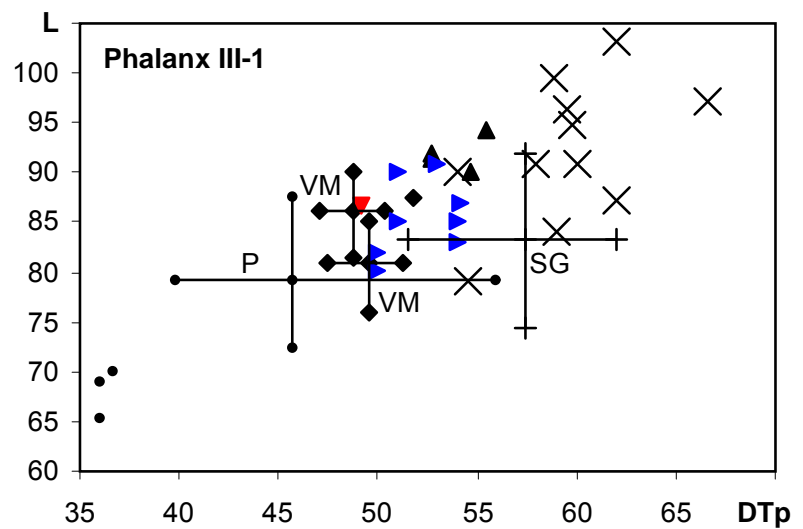

$5 \mathrm{~cm}$

PV La Puebla de Valverde $n=12 / 11$ VM Venta Micena ant $n=6$, post $n=7$ SV Saint-Vallier $n=17$ $S$ Senèze $n=10 / 14$

\begin{tabular}{|c|c|c|}
\hline E stenonis & $\diamond$ & Ubeidiya \\
\hline Selvella & $\bullet$ & $E$ altidens \\
\hline Pirro Nord & $\boldsymbol{\nabla}$ & Atapuerca TD8 \\
\hline
\end{tabular}
- Libakos

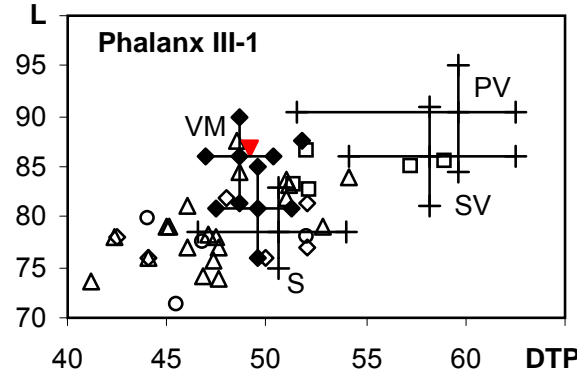

Figure 6

The right first phalanx (III-1) of Equus altidens from Atapuerca TD8 - Ata94, TD8, t31, I-16, 65: 1a) dorsal, and 1b) proximal views.

Bivariate diagrams of the distal articular width (DTdf) and length (L) of the third metacarpal comparing a specimen from Atapuerca TD8 to those of selected Equidae. The difference between robust and gracile equids is also noted, though not as clear as in the Mc.

Provenance of data: robust caballoid Equus from Saint-Germain-la-Riviere (Prat, 1980), gracile E. wuesti from Untermassfeld (Musil, 2001), E. nalakhensis from Nalaikha (Eisenmann \& Kuznetsova, 2004), E. altidens from Venta Micena (Marín, 1987), E. petraloniensis from Petralona (Tsoukala, 1989), E. hydruntinus from Lunel Viel (Eisenmann \& Mashkour 1999) and Arenero Santa Catalina (Madrid; MAN) and the intermediate E. suessenbornensis from Süssenborn (Musil, 1969), Soleilhac (Prat, 1980) and Tiraspol (Gromova \& Dubrovo 1975). 
and $E$. wuesti, it is in the upper ranges of the intermediate species and is in the range of $E$. altidens.

Other specimens, less important for the systematics of Equus, are not described here, but are listed in Tables 1-5.

\subsubsection{Remarks on context and taxonomy}

There are no very recent comprehensive reviews on European Pleistocene Equidae, but the published opinions (Azzaroli, 1990; Eisenmann, 1991; Guérin, 1996d; Forsten, 1999; Alberdi et al., 1998) differ markedly in the species recognized and their chronologic distribution. It seems to be accepted that there are but few morphological features of taxonomical value and there is a longstanding consensus that the size and proportions of the metapodials and phalanges are of prime importance (Sickenberg 1962; Forsten, 1973, 1999; Eisenmann, 1979, 1991; Alberdi et al., 1995), even though these are used in different ways. Forsten (1999) used mainly size and proportions of the phalanges and metapodials, but did not use indices because she assumed allometry to interfere with the skeletal proportions. However, the differences in size between these species are very modest and allometry is not likely to cause important differences in proportions.

The range chart in Figure 5 uses the most commonly accepted names and/or those used by Forsten (1999) and in addition some more recently published names. Different interpretations of the ages of the localities and some different assignations of specimens or samples explain differences in temporal ranges with Forsten's figure 16 .

The smaller stenonid species (right part of the range chart), are of relevance here. These species differ in robusticity of the metapodials and phalanges with $E$. stenonis on the robust end of variation and the geologically younger $E$. altidens and $E$. hydruntinus on the gracile end. Samples of intermediate age and intermediate degree of robustness have either been included in E. stenonis or in E. altidens. There are three proposals for the origin of Equus altidens (Van der Made, 2013):

1) Alberdi et al. (1995) proposed that it evolved from E. stenonis and the overall trend from robust to gracile, to some extend, supports the proposal of Alberdi et al. (1995). This is the case with the metacarpals and phalanges (Figures 4, 5, \& 6), but also with the metatarsals. There is a problem here that the earliest samples with an intermediate degree of robusticity (as Gerakarou) are not after, but contemporaneous with robust $E$. stenonis, suggesting, that the two lineages overlapped in time. Gerakarou is the type locality of Equus mygdoniensis and if the species with an intermediate degree of robusticity are all the same species, this would be an available name for them. In addition, there is also a smaller species with metapodials of intermediate robustness, which is either called E. senezensis or E. stehlini. The transition of the larger intermediate form (as present in Selvella, Libakos and Pirro Nord) to the gracile E. altidens (as in Venta Micena) may well have been conform Alberdi's model.

2) It has been proposed that E. altidens evolved from the African species E. tabeti, and that it dispersed shortly after 1.8 Ma to Europe (e.g. Guerrero-Alba \& Palmqvist, 1997). In this view, the material from Ubeidiya (described by Eisenmann, 1986) also belongs to E. tabeti and fills the temporal gap between the last African representative of that species and the first European E. altidens. However, the horse from Ubeidiya is more robust than either E. tabeti or E. altidens and is similar to that of Pirro Nord, Selvella and Libakos. As a consequence, deriving E. altidens from the population from Ubeidiya is in fact arguing for Alberdi's model. This also leaves a long time gap, of about $600 \mathrm{ky}$, between the African E. tabeti and the appearance of E. altidens in Europe.

3) A third alternative, is that E. altidens dispersed from Asia, where it evolved from E. qingyangensis, which is reported there to have ranged from 2.5 to about 1.2 Ma (Deng \& Xue, 1999). In fact, this species is very similar to $E$. nalaikhensis and $E$. wuesti and all are as gracile but a little larger than $E$. altidens. It is not clear, whether E. altidens had size fluctuations in time, and whether E. wuesti and E. nalaikhensis are large subspecies of $E$. altidens or contemporary larger species.

4) Yet another scenario would be deriving E. altidens from E. livenzovensis, which is much larger, but also relatively gracile. However, the latter is an earliest Early Pleistocene species and the scenario would imply a ghost lineage of nearly 1 My.

Given the apparent gradual transition within western Eurasia, a local origin of E. altidens by evolution seems most likely.

Most of the samples of E. altidens, included in Figure 5, are of single specimens and therefore there is more apparent variation in the values, than in the means of large samples. E. petraloniensis and E. hydruntinus are still more gracile and are smaller than E. altidens. Equus hydruntinus is a possible descendant of E. altidens (Musil, 1969; Forsten, 1990) and Equus petraloniensis is intermediate between the two in metacarpal and phalanx biometrics (Figures 3 \& 4), as well as in age. Equus altidens became rare towards the end of its temporal range and it is possible that samples of insufficient size are assigned to this species, while they fit better E. petraloniensis, a species which is less widely known and cited. This might be the case with the material 
from Cúllar de Baza (Alberdi \& Ruiz-Bustos, 1987). A gradual evolution from one to the other species is possible. A very small equid from Lunel Viel was described as E. hydruntinus minor, but is so much smaller that it could be a different species. Equus hydruntinus seems to be closely related to the living E. hemionus (Orlando et al., 2006), though it retains shorter protocones (Figure 3).

Material from the lower levels of Gran Dolina has previously been assigned to "Equus stenonis aff. granatensis” “Equus sp. stenonid type”, “Equus cf. altidens” and finally “Equus altidens” (Maldonado Diaz, 1996; Van der Made, 1998a, 1999a; Rosell et al., 2010). The latter more precise classification is based on material from the more recent excavations, including the metacarpal figured here (Figure 4), phalanx (Figure 6) and dental material (Figures 3/1-3). The linguaflexids of the lower cheek teeth indicate that this is a stenonid species (Figure 3/2-3), which is supported by the short protocone (Figure 3 upper diagrams). The metacarpal and phalanx (Figures 4-6) indicates that it belongs to one of the gracile stenonid species, the size of the metacarpal indicates it is larger than E. hydruntinus and E. petraloniensis, and the size of the third phalanx that it is more likely E. altidens than E. wuesti or E. nalaikhensis. The material belongs to E. altidens.

If an evolution from E. stenonis, or at least from the equid from Libakos and Pirro Nord to E. altidens and, then to E. petraloniensis and E. hydruntinus is assumed, this has various implications. The first ones concerns the temporal range of $E$. altidens and its application in biochronology. The localities with metapodials with an intermediate degree of robustness include Selvella, Libakos and Pirro Nord and the first with a really gracile Equus, that is widely accepted to belong to E. altidens, is Venta Micena (a large sample described as E. granatensis by Alberdi \& Ruiz Bustos, 1985 and Marín, 1987). Material from the nearby locality of Fuente Nueva 3 is assigned to the same species (Alberdi, 2010). If the model of evolution of E. altidens is correct, these localities in the Orce area are thus younger than Selvella, Ubeidiya, Libakos and Pirro Nord. Human presence in the Orce area at Venta Micena is disputed, but at Fuente Nueva 3 and Barranco León it is firmly established (Toro-Moyano et al., 2013). These localities are geographically and stratigraphically close and may be younger than Pirro Nord, where lithic industry confirms human presence (Arzarello et al., 2007, 2012) and Ubeidiya, where human presence has since long been recognized.

The type locality of E. altidens is Süssenborn, with an age of about $650 \mathrm{ka}$, based on biochronology, and in Elsterian sediments (stage 16). If material from Cúllar de Baza, already belongs to Equus petraloniensis, the transition to this species should be after $650 \mathrm{ka}$ (age of Süssenborn) and before $476 \pm 24 \mathrm{ka}$ (date for Cúllar de Baza; Ortiz et al., 2000). The temporal range of E. altidens is from about 1.2 Ma to some 0.55 Ma. The age of TD8 is slightly younger than $780 \mathrm{ka}$ and fits in this range.

The remaining implication is that, if Equus altidens evolved in Europe from an equid with moderately gracile metapodials, present in Selvella, Libakos, Pirro Nord, and also Ubeidiya, it did not originate in Africa from the very gracile E. tabeti. The scenario, that around 1.8 Ma ago, E. altidens dispersed from Africa to Europe, together with Homo and other large mammals, including Hippopotamus, Megantereon whitei and Pachycrocuta, (e.g. Guerrero-Alba \& Palmqvist, 1997), seems less likely.

\subsection{Rhinoceros}

Family Rhinocerotidae Gray, 1821

Genus Stephanorhinus Kretzoi, 1942

Stephanorhinus aff. etruscus (Falconer, 1868)

\subsubsection{Material}

Ata94, TD8, t28, I-16, 16 - Phalanx III-1 sin.

Ata94, TD8, t29, H-16, 52 - protocone of $\mathrm{M}^{\mathrm{x}}$.

Ata94, TD8, t29, H-16, 63 - buccal wall of right upper cheek tooth.

Ata94, TD8, t29, I-16, $35-\mathrm{P}^{2} \sin$.

TD8 (A) - Fragment of phalanx III-3.

Ata2002, TD8B, F-12, $50-\mathrm{D}_{3}$ dext.

Ata06, TD8B, H-4, 8 - D Dext. $^{2}$ deal

The measurements of this material are given in Table 6 (supplementary data). A taphonomic study assigned 9 fossils to the rhinoceros, representing a minimum of 2 individuals (Rosell, et al., 2010).

\subsubsection{Description and comparison}

The teeth have the typical structure of rhinoceros teeth and the enamel is relatively smooth as in most species of Stephanorhinus. Of the European Pleistocene rhinoceroses (Figure 7), the enamel in the cheek teeth of Stephanorhinus hemitoechus is clearly more and of Coelodonta much more crenellated.

The general size of the teeth is smaller than in S. kirchbergensis and the size of the $\mathbf{P}^{2}$ (Figure 7-3) in 


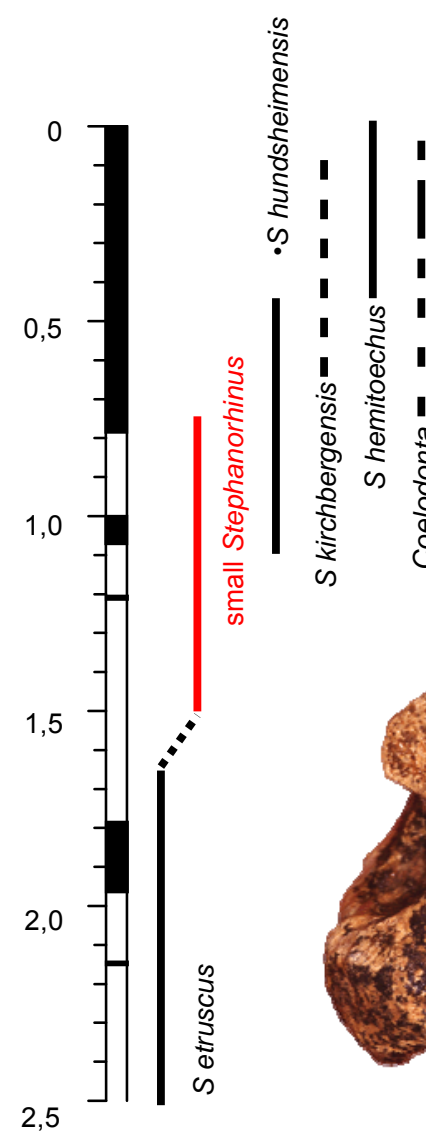

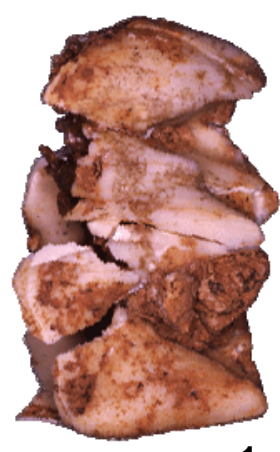

1a $1 b$

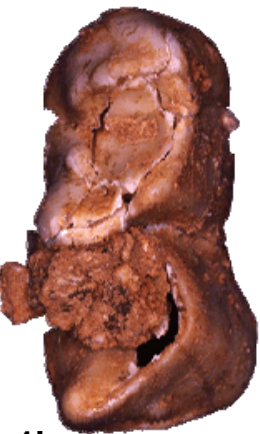

b

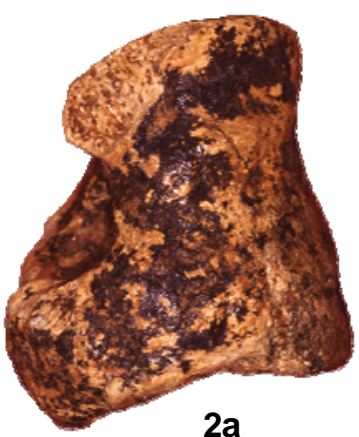

$2 a$

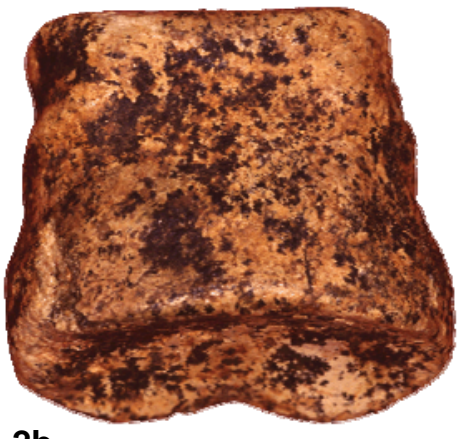

2b

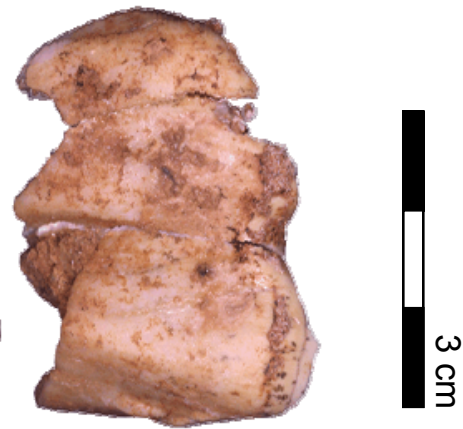

1c $\stackrel{\omega}{3}$
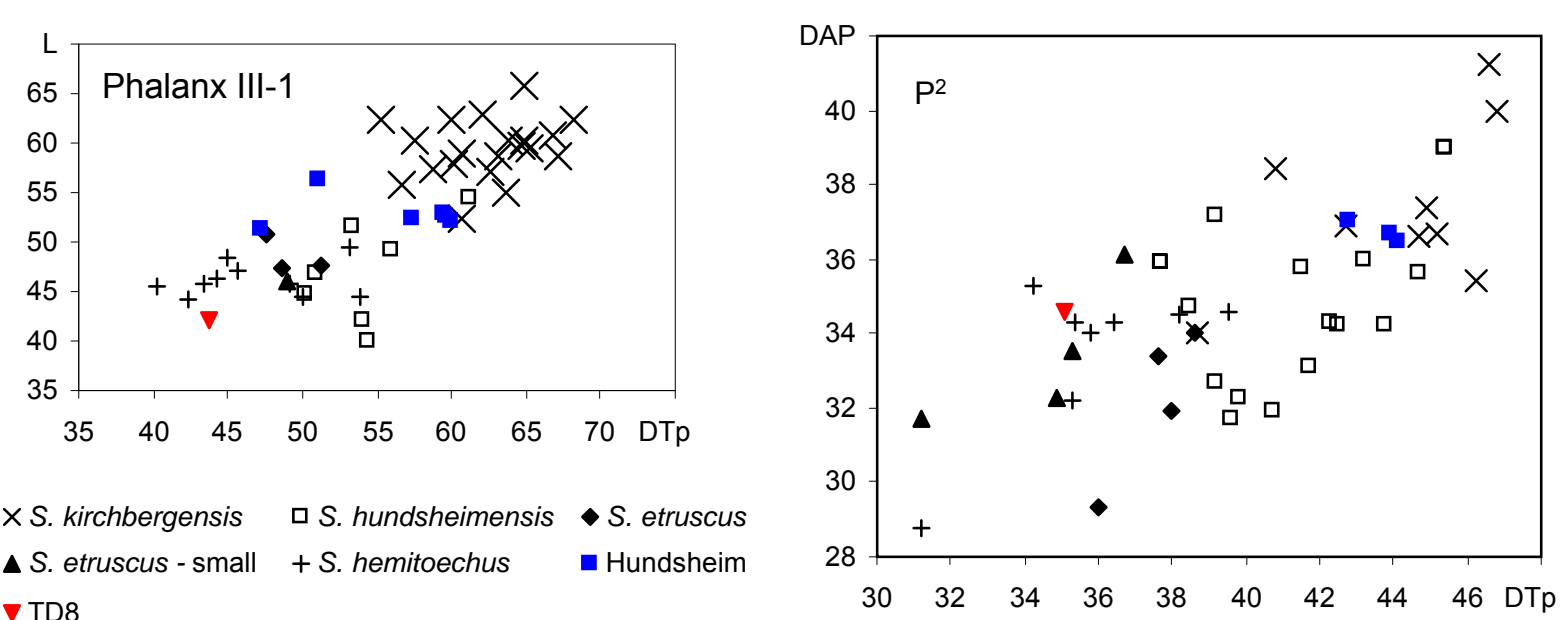

$\times$ S. kirchbergensis $\quad$ S. hundsheimensis $\bullet$ S. etruscus

$\Delta S$. etruscus - small $+S$. hemitoechus $\nabla$ TD8
Hundsheim



3

Figure 7

Stephanorhinus aff. etruscus from Atapuerca TD8: 1) Ata2002, TD8B, F-12, 50 - D3 dext.: a) lingual, b) occlusal, and c) buccal views. 2) Ata94, TD8, t28, I-16, 16 - Phalanx III-1 sin.: a) lateral, and b) dorsal views. 3) Ata94, TD8, t29, I-16, 35 - P2 sin.: buccal view.

The chronologic distribution of the European Pleistocene Rhinocerotidae (after Van der Made \& Grube, 2010). Conventions as in Figure 3; Coelodonta is present mainly in glacials and S. kirchbergensis only in interglacials, these are not "dashed lines” but indicate discontinuous presence in Europe.

Bivariate diagram of the proximal width (DTp) against length (L) of the first phalanx comparing the Stephanorhinus from TD8 to Stephanorhinus aff. etruscus from Atapuerca TD7/2 (IPHES), S. etruscus from the Upper Valdarno (IGF); S. hundsheimensis from Untermassfeld (IQW) and Mauer (SMNK); and from Hundsheim (NMW); S. hemitoechus from Arago (LPTUP), Bilzinglseben (FBFSUJ), Atapuerca TD10 (IPHES), and Azokh 1-V (MUB); S. kirchbergensis from Bilzingsleben (FBFSUJ).

Bivariate diagram of the proximal width (DTp) against length (L) of the first phalanx comparing the Stephanorhinus from TD8 to Stephanorhinus aff. etruscus from Libakos (TUC), Huéscar 1 (MNCN), Atapuerca TDW4 (MB), and Cueva Victoria (MAC); S. etruscus from the Upper Valdarno (IGF); S. hundsheimensis from Vallonnet (MPRM), Dorn Dürkheim (FISF), Voigtstedt (IQW), Süssenborn (IQW), Mosbach (NMM), Soleilhac (MCP), Mauer (SMNK), Mosbach (NMM), and from Hundsheim (NMW); S. hemitoechus from Bilzingsleben (FBFSUJ), Murr (SMNS), Ehringsdorf (IQW), and the Rheinebene (NMM); S. kirchbergensis from Bilzingsleben (FBFSUJ), Ehringsdorf (IQW), Neumark Nord (FBFSUJ), and Gimbsheim (Rheinebene; NMM). 
particular is smaller than in S. hundsheimensis and comparable to that of S. etruscus, S. hemitoechus and a rhinoceros indicated here as $S$. aff. etruscus (Figure 7 bivariate diagram).

A lower decidual molar has the paraconid and parastylid separated (Figure 7-1), which would suggest the tooth to be a $D_{2}$, but the tooth is far to large, so it is probably a $\mathbf{D}_{3}$. Both valleys are V-shaped, if seen from the lingual side.

A first central phalanx (Phalanx III-1; Figure 7-2) has the common rhinoceros morphology, and is smaller than the few specimens of $S$. etruscus and $S$. aff. etruscus, and is clearly smaller than $S$. hundsheimensis, which is represented by a better sample (Figure 7 bivariate diagram).

\title{
3.2.3. Remarks on context and taxonomy
}

The material from TD8 is relatively small and as appears from the comparisons made above, its resemblances are in particular with S. etruscus and S. aff. etruscus, and in fact, material from the lower levels of Gran Dolina has been assigned previously to S. etruscus (Cerdeño, 1993; Van der Made, 1998a, 1999b, etc.). Barring nomenclatorial and other differences of minor importance, there are presently three opinions on the evolution and affinities of these rhinoceroses:

1) S. etruscus evolved into a small S. aff. hundsheimensis and then into S. hundsheimensis (Guérin, 1980, 1996c; Cerdeño, 1993; Mazza et al., 1993; Kahlke, H.D. 2001b).

2) S. jeanvireti evolved into the small rhinoceros, which is already $S$. hundsheimensis, while S. etruscus is a lineage that went extinct in western Europe (Lacombat 2005, 2006, 2009).

3) S. etruscus evolved into the small rhinoceros, either called S. etruscus or $S$. aff etruscus, while $S$. hundsheimensis is a different lineage (Van der Made, 2010; Van der Made \& Grube, 2010; Giles Pacheco et al., 2011).

These three models have been discussed, and the species were found to differ in proportions in the tooth row and of the limb bones, but the relationships between them is still an open question (Van der Made, in press). The $\mathrm{P}^{2}$ and first phalanx from TD8 are small and cluster best with $S$. aff. etruscus and S. etruscus whereas $S$. hundsheimensis has these elements large. However, in the size of other elements (not represented in TD8), there are also differences between $S$. aff. etruscus and S. etruscus. Whereas the scant material from TD8 is not resolving the relationship between these different rhinoceroses, its assignation to $S$. aff. etruscus is justified.

\subsection{Pig}

\author{
Order Artiodactyla \\ Family Suidae \\ Genus Sus Linnaeus, 1758 \\ Sus scrofa Linnaeus, 1758
}

\subsubsection{Material}

Ata06, TD8B, G-4, 145 - left $\mathrm{M}^{1}$.

A taphonomic study assigned 2 fossils to a suid, representing a minimum of 1 individual (Rosell, et al., 2010).

\subsubsection{Description and comparison}

The $\mathbf{M}^{1}$ (Figure 8/3) is bunodont with four cusps, as is common in the $\mathrm{D}^{4}$ and $\mathrm{M} 1-2$ of the Suidae. One of the anterior cusps has three posterior lobes, these are the protopostcrista and the internal and external protoendocrista (terminology of Van der Made, 1996). Such a morphology occurs in the $\mathrm{D}^{4}$ and $\mathrm{M}^{1-3}$ of nearly all Suoidea, but not in other groups. The anterior cingulum is perpendicular to the long axis of the tooth, while it is oblique in the $\mathrm{D}^{4}$. Like in the genus Sus, the $\mathrm{M}^{1-2}$ is a little more elongate and the crests are more marked than in primitive Suoidea. With a length of $18.2 \mathrm{~mm}$ and anterior and posterior width of 16.4 and $16.7 \mathrm{~mm}$, the specimen is within the metrical ranges of Sus scrofa and outside those of Sus strozzii (Figure 5).

\subsubsection{Remarks on context and taxonomy}

At present two species of Sus are recognized in the Pleistocene of Europe: Sus strozzii and Sus scrofa. From the literature there appear to be two different views on their temporal distribution.

1) Faure \& Guérin $(1984,1992)$ and Guérin (1996a) considered Sus strozzii to be present already at the beginning of the Pleistocene and to reach the beginning of the Middle Pleistocene, when it was replaced by Sus scrofa; both species were indicated to be present in zone MNQ 20. It should be noted that their Middle Pleistocene starts earlier than the present definition at $780 \mathrm{ka}$.

Faure \& Guérin (1984) listed Ubeidiya and Tegelen as the youngest localities with Sus strozzii. The 



Figure 8

The chronologic distribution of the Pleistocene European species of Sus and Hippopotamus. The temporal scale and plaeomagnesm to the left, localities according to their approximate age, the presence of a species in a locality is indicated with a solid square, while tentative or possible (cf., aff., sp., ?) presence is indicated with an open square.

Bivariate diagram of width of the anterior lobe (DTa) against length (DAP):

Sus strozzii from: Gerakarou (AUT), Senèze (UCBL), Tegelen (NBC, MNB), Olivola (IGF), Valdarno (IGF, AVP), Il Tasso (IGF); and Sus scrofa from: Atapuerca TD8 \& TD10 (IPHES), Koneprusy (PIMUZ, cast), Mosbach (NMM), Mauer (SMNK), Trimingham (NHM), Megalopolis (AUT), Taubach (IQW), Pinilla del Valle (UCM), Kafzeh (IPH), Can Rubau (CIAG), Sakazia (GSM), Cueva de Saldarañao (ETSI), Német Bogsan (HGSB), and recent Sus scrofa from Spain, the Netherlands and Germany (MNCN, ZMA, NBC, DGFSUPV).

Photographs. 1) Ata94, TD8, t29, I-16, 62 - right I2? of Hippopotamus sp. from TD8: a) mesial, b) lingual, and c) labial views. 2) Ata2002, TD8b, G-7, 32 - right second central phalanx (phalanx III/IV-2) of Hippopotamus sp. from TD8: a) distal, b) dorsal, c) abaxial, d) plantar, and e) proximal views. Sus scrofa from TD8: Ata06, TD8B, G-4, 145 left M1 occlusal view (photograph). 
occurrence of Sus strozzii at Ubeidiya (Geraads et al., 1996; zone MNQ19) seems to be universally accepted, but is not in Europe. The record from Tegelen was indicated to be from zone MNQ 20, but rodents collected from a channel cut into in the sediments that yielded the large mammals, indicate that this is a much older locality (Freudenthal et al., 1976). As a result, the last European record of Sus strozzii listed by Faure \& Guérin (1984) is in Mugello (Farneta Unit, about 1.5 Ma; Sardella et al., 1998).

Guérin \& Faure (1997) and Guérin (1980) described and mentioned material from Untermassfeld, Vallonnet and Ceyssaguet (all zone MNQ 20 or MmQ3) as Sus scrofa, though the sample from Vallonnet had been assigned to Sus strozzii (Moullé, 1998). The male lower canines in these samples are of the "verrucose type" as in Sus strozzii and unlike in Sus scrofa.

2) Van der Made \& Moyà Solà (1989) and Van der Made (1990a, 1990b, 1997) gave range charts, where there is a gap in the available data between the last record of Sus strozzii and the first record of Sus scrofa. This gap corresponds to zone MmQ2 of Agustí et al. (1987) and Guérin’s (1980) zones MNQ 18-19, which have a low density of fossil localities (see Van der Made, 2011a, figure 1, and corresponding text). Nevertheless, suids are cited from Atapuerca TE9 (Rodríguez et al., 2011), Ceyssaguet (Guérin \& Faure, 1997), Pirro Nord (De Giuli et al., 1987), Selvella (De Giuli, 1987), and Mugello (Faure \& Guérin, 1984) and are present in Peyrolles (fossils in NHM). These localities cover the whole range from the well known records of Sus strozzii from the Upper Valdarno (Olduvai subchron) till Untermassfeld and Vallonnet (Jaramillo subchron).

The living species, Sus scrofa, is first documented with certainty in Atapuerca TD6 (Van der Made, 1997, 1999a). Atapuerca TD6 is in sediments with inverse polarisation below the Santa Rosa palaeomagnetic event in level TD7 and therefore its age should be between 0.936 and 0.98 Ma (Parés et al., 2013). The ranges of the different species are indicated in Figure 8. Though it is clear that there is a period with a poor suid record, the youngest samples with "verrucose” canines approach the oldest record Sus scrofa. The replacement of one species by the other must have been around the end of the Jaramillo Event and very fast, with no temporal hiatus in between. At present, there is no evidence of a period without Suidae in the Early Pleistocene of Europe.

In size and morphology, the specimen from TD8 fits best an $\mathrm{M}^{1}$ of Sus scrofa and the age of the specimen fits the known temporal range of this species. This is one of the oldest records of the species.

\subsection{Hippopotamus}

Family Hippopotamidae Gray, 1821

Genus Hippopotamus Linnaeus, 1758

Hippopotamus sp.

\subsubsection{Material}

Ata94, TD8, t29, I-16, 62 - right $\mathrm{I}^{2}$.

Ata2002, TD8b, G-7, 32 - right second central phalanx (phalanx III-2).

A taphonomic analysis assigned a single fossil to the hippopotamus, representing a minimum of one individual (Rosell, et al., 2010).

\subsubsection{Description and comparison}

The upper incisor (Figure 8/1) has a height of about 13 to $14 \mathrm{~cm}$ and a linguo-labial diameter of 34.2 and a meso-distal diameter of $30.9 \mathrm{~mm}$. It is curved with the inner and outer radius of curvature of 7.5 and $11 \mathrm{~cm}$, respectively. There is a labial enamel band with a width of about $14.3 \mathrm{~mm}$ near the tip and $2.1 \mathrm{~mm}$. near the base. The pulp cavity is open. It has a large apico-lingual facet, caused by occlusion with the lower incisor, which seems to be more typical of the second than of the first upper incisors (which tend to have a medially oriented facet) of the hippopotami.

A phalanx (Figure 8/2) is close in size and proportions to the first phalanx of Stephanorhinus, which is also present in the locality (Figure 7/2). Its dimensions are: DAPp=27.3, DTp=40.2, L=44.9, DAPd=--, $\mathrm{DTd}=38.4$. However it differs from the rhinoceros phalanx in a number of features. In side view, the proximal facet is more concave. In proximal view, the proximal facet is more square at the plantar side. In dorsal view, the proximal edge of the dorsal surface is convex towards proximal. In dorsal view, the distal articulation is not straight, but has a grove in the middle. In distal view, the plantar edge of the distal facet is not straight, but is elevated in the middle. The specimen is much more elongate and has other morphological differences with the rhinoceros second phalanx. Proboscidean phalanges are much larger. The first phalanx of a hippopotamus may be much more elongate, and the second shorter (R.D. Kahlke, 1997b, plate 56, figs. 15-24). However, the specimen is close in size and proportions to a phalanx IV-2 of the hand of a recent Hippopotamus in the MNCN. The plantar edge of the proximal side is a little more straight in the fossil, but otherwise the morphology fits.

\subsubsection{Remarks on taxonomy and evolution}


For a long time, the first appearance of Hippopotamus in Europe has been a point of discussion. Faure (1985) reviewed the West European hippos and noted that it is present in various localities of the Upper Valdarno, and that outside Italy, it is present in Sainzelles and other localities, believed then to be Middle Pleistocene in age. Presently Sainzelles is believed to be late Early Pleistocene. Since they would be so much older, Faure had doubts about the exact provenance (and age) of the Valdarno specimens.

Subsequently, other localities close in age to Sainzelles have also yielded hippos: Untermassfeld, Libakos, Aliakmon, Atapuerca TE7 and TE14, Venta Micena, Barranco León (R.D. Kahlke, 1997b, 2001c, 2006; Steensma, 1988; Rodríguez et al., 2011; Alberdi \& Ruiz Bustos, 1985; Gibert et al., 1992). Rook \& Martínez-Navarro (2010) considered the entry of Hippopotamus typical of the Colle Curti faunal unit (which correlates to the Jaramillo Event), but remained silent about the material from the Upper Valdarno (e.g. Blandamura \& Azzaroli, 1977).

Bellucci et al. (2012, 2014) reported on a hippo specimen from Coste San Giacomo. This would strengthen the case for Hippopotamus in Italy between some 2.1 and 1.8 Ma. However, the problem remains that all other European localities seem to be much younger. This recalls the situation around the Mio-Pliocene transition, when a more primitive hippopotamus reached Italy, Spain and the South of France, but did not disperse further north, and went extinct after a relatively short time (Van der Made, 1999b). It is not impossible, that Hippopotamus reached Italy around 2-1.8 Ma, went extinct, and later, around 1.2 Ma, dispersed again into Italy and other parts of Europe.

There are different opinions on the taxonomy of the European species of Hippopotamus. They are seen as two species, the large early Middle Pleistocene Hippopotamus major ( $=H$. antiquus) and the smaller early Middle to Late Pleistocene $H$. incognitus (Faure, 1985; Guérin, 1996a), or as two subspecies of the living $H$. amphibius (R.D. Kahlke, 1997b, 2001c, 2006). Alternatively, $H$. antiquus is believed to have given rise to $H$. tiberinus, the two coexisting for a while, while later the latter species coexisted with H. amphibius (Mazza, 1991).

Mazza (1991) believed the European hippos to have originated from Hippopotamus gorgops, which is known from Olduvai. Interesting in Mazza's model is that the early Middle Pleistocene $H$. tiberinus has a short brain case, and elevated orbitas and occiput, in which it resembles the African $H$. gorgops. However, $H$. major from the Upper Valdarno does not have such an occiput. Since Mazza's paper, the age of the Upper Valdarno deposits is known to be older than previously believed and older than Olduvai Bed 1. A possible scenario is that $H$. antiquus originated from an African form that did not yet have the typical orbita and occipital morphology of $H$. gorgops, while later, $H$. tiberinus originated later from $H$. gorgops and dispersed into Europe. Skull morphology from Untermassfeld would support this scenario (R.D. Kahlke, 2001c, fig. 5, pls. 77-78; 2006, fig. 12). Again according to Mazza (1991), late Middle or Late Pleistocene European hippos do not have this morphology of the orbitas and occiput, but resemble in these features the living species $H$. amphibius. They are also smaller. This would then represent another dispersal event from Africa to Europe in the late Middle or early Late Pleistocene.

Hippopotamus georgicus is known from Akhalkalaki by some limb bones Vekua (1986). It is a large hippo, like $H$. tiberinus and it is of the same age. In case of a synonymy, the name with priority is $H$. georgicus. However, considering that $H$. amphibius had a range stretching from Africa to mid-latitude Europe, it could be questioned, whether the European $H$. tiberinus is not a variety or subspecies of $H$. gorgops. The European hippos arose most probably from North African populations. The species $H$. sirensis has been defined on the basis of material from Tighenif (Ternifine, Palikao; see Pomel, 1896) and might be another name that has priority over $H$. tiberinus, $H$. georgiensis or $H$. gorgops. An extensive taxonomical study is necessary to solve this problem.

These species mainly differ in size, the elevation of the orbitas and the position and morphology of the occiput. Incisors tend to increase their diameter from the tip to the base, and tend to continue growing. There are very few published data on phalanx size. For these reasons, the material from TD8 cannot be assigned to one of the European species or subspecies. Because of their age, these specimens are expected to belong to $H$. tiberinus, but more material is needed to confirm this.

\subsection{Red deer}

Family Cervidae Goldfuss, 1820

Genus Cervus Linnaeus, 1758

Cervus elaphus Linnaeus, 1758

\subsubsection{Material}

Ata94, TD8, t28, I-16, 9 - left $\mathrm{P}^{3}$ and fragment of left $\mathrm{M}^{\mathrm{x}}$. 
Ata94, TD8, t28, G-17, 22 - shaft of right tibia.

Ata04, TD8b, G-5, 4 - distal part of the right scapula.

Ata94, TD8, t29, H-16, 59 - proximal epiphysis of the second phalanx, left of the axis of the foot, juvenile.

Ata94, TD8, t29, I/H-16, sc - distal part of the second phalanx, left of the axis of the foot.

Ata03, TD8b, I-9, 72 - first phalanx, right of the axis of the manus/pes, distal part.

Ata04, TD8b, G-14, 4 - proximal epiphysis of the second phalanx, left of the axis of the foot, juvenile.

Ata05, TD8b, F-13, 2 - second phalanx, right of the axis of the foot.

? Ata02, TD8b, H-8, 14 - tine of an antler.

? Ata94, TD8, t29, G-16, 59 - right calcaneum, juvenile.

? Ata94, TD8, H-16, 19 - left first central phalanx (phalanx III/IV-1), juvenile.

? Ata94, TD8, t28, G-16, 32 - left first central phalanx (phalanx III/IV-1), juvenile.

The measurements of this material are given in Table 7 (supplementary data). A taphonomic study assigned 94 fossils to Cervidae indet., representing a minimum of 5 individuals (Rosell, et al., 2010); part of this material is here assigned or tentatively assigned to the red deer.

\subsubsection{Description and comparison}

If seen from anterior, the $\mathbf{P}^{3}$ has the lingual side convex, as is the case in Cervus and unlike in Dama, Megaceroides or Eucladoceros. It is a little smaller than the Megaceroides $\mathrm{P}^{3}$ with which it has been compared and it is much smaller than the $\mathrm{P}^{3}$ of the large Eucladoceros from around the E-M Pleistocene transition (Akhalkalaki, Apollonia 1, Lakhuti, Dursunlu; GSM, AUT, PIN, MTA).

The scapula has the tuberosity slightly down turned as in Cervus elaphus, but not distinctly hooked (feature 1 of Lister, 1996). Metrically, the specimen is in the range of large Cervus elaphus as from Neumark Nord (FBFSUJ) and it is much smaller than in Eucladoceros giulii (H.D. Kahlke, 1997, table 61) and Megaceroides from Voigtstedt (IQW).

The shaft of a tibia is not very informative, but it indicates an animal the size of Cervus elaphus. Other bones are of juveniles (or a juvenile), their morphology and final size is not yet well established and as a consequence their assignment to this taxon is tentative.

Of four second phalanges, one is complete (Figure 9/3). Lister (1996) gave one feature to discriminate between red and fallow deer phalanges: the emargination on the axial side of the dorsal edge of the proximal facet, which is present in Dama and absent in Cervus. It is absent here. This emargination is also faintly present in a specimen assigned to Eucladoceros aff. giulii from TD6. The complete specimen is narrow (Figure 9 DTdDAPd diagram) and elongate (Figure 9 DTp-L diagram) and is in the metrical ranges of a large Cervus elaphus as from Neumark Nord, and in some of its measurements is slightly smaller than the specimens assigned to Megaceroides and Eucladoceros aff. giulii, and the fragmentary specimens are still smaller. Even the latter specimens are still clearly larger than those of Dama from TD8 (Tables 7 and 25).

A tine of an antler with part of the main beam, might represent the tine above the bez-tine. In Cervus elaphus this is the third tine (after the brow and bez tine), if it were Dama, it might be the homologous time, which in this case is the second tine (since no bez tine is developed).The latter option seems less likely, in view of the morphology of an antler from TE7, which is assigned to Dama.

\subsubsection{Remarks on context and taxonomy}

Cervus elaphus is well known from the Middle Pleistocene of western Europe, but it is cited or described from a few late Early Pleistocene localities, which would make its appearance nearly 300 ky older.

Cervus elaphus is cited from Mosbach 1 (Von Koenigswald \& Tobien, 1987), which is correlated to the Jaramillo Subchron. The locality is in a sand pit, which has three fossiliferous levels. The oldest, Mosbach 1, is in a discontinuous unit, called Grobes Mosbach (grob = coarse, referring to the grain size of the sands). This unit is overlain discomformably by the Graues Mosbach (grau = grey, referring to the colour of the sands), which contains fossiliferous levels 2 and 3. The richest fauna is from Mosbach 2 and is mainly composed of "interglacial” species, with a possible age of 500-600 ka. In the younger Mosbach 3, "glacial” species are more prominent. Most fossils of the historic collections from Mosbach lack precise provenance data. Von Koenigswald \& Tobien (1987) provided faunal lists for these three levels, but did not indicate on which fossils the lists are based. Material from Trlica in Montenegro has been assigned to Cervus elaphus and is probably preJaramillo in age (Derevjanko et al., 2012; Van der Made \& Dimetrijević, in press; Bogićević \& Nenadić, 2008).

At present, the oldest unambiguous West European records of Cervus elaphus are from Dorn Dürkheim (Franzen et al., 2000), Atapuerca TDW4, where an antler with bez tine was recovered (Bermúdez de Castro et al., 1999, figure on p. 90) and Happisburgh HSB3 (Parfitt et al. 2010). Dorn Dürkheim is below the BrunhesMatuyama boundary. Happisburgh HSB3 is correlated to stage 21 or 25. Atapuerca TDW4 is well below the Santa Rosa palaeomagnetic event in level TD7, but still above the Jaramillo Event, and therefore its age should 


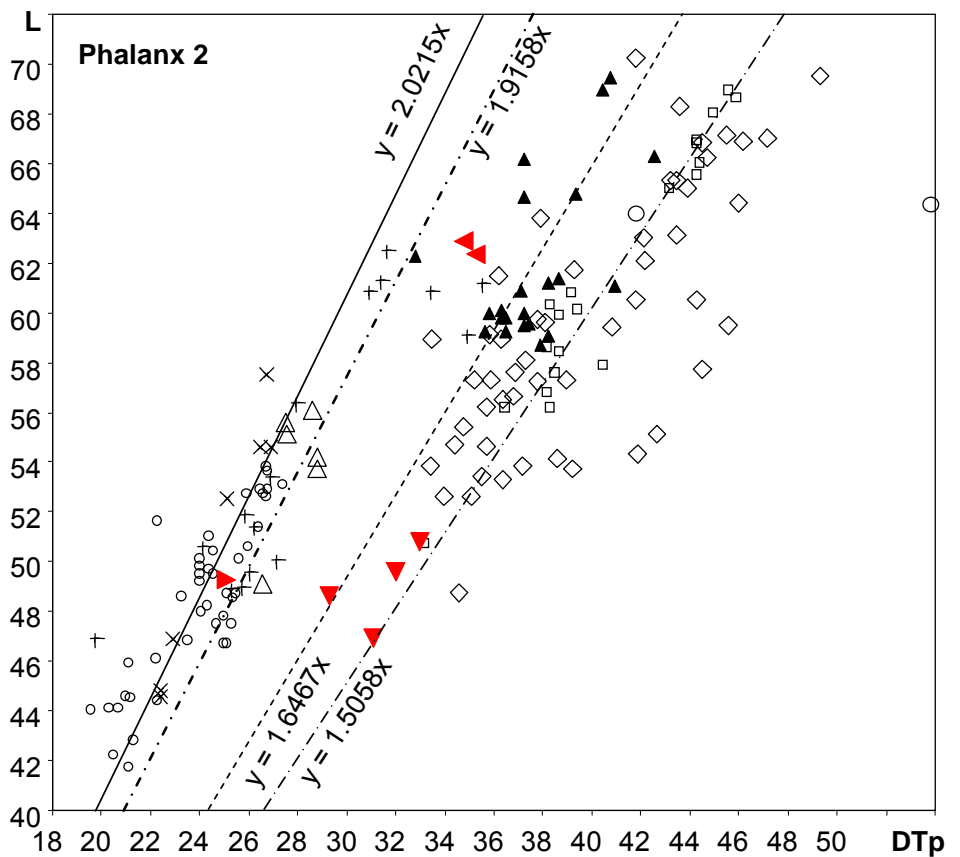

$$
\begin{array}{cl} 
& \text { Cervus elaphus TD8 } \\
& \text { Bison voigtstedtensis TD8 } \\
& \text { Megaceroides TD8 } \\
\circ & \text { Cervus elaphus } \\
\square & \text { Bos } \\
\triangle & \text { Bison menneri } \\
\diamond & \text { Bison schoetensacki } \\
\bigcirc & \text { Bison priscus } \\
\triangle & \text { Eucladoceros giulii / aff giulii } \\
+ & \text { Megaceroides } \\
\times & \text { small Eucladoceros } \\
\hline & \text { Cervus elaphus } \\
\cdots & \text { Bison schoetensacki } \\
\cdots & \text { Bison menneri } \\
& \text { Megaceroides }
\end{array}
$$

$1 \mathrm{a}$
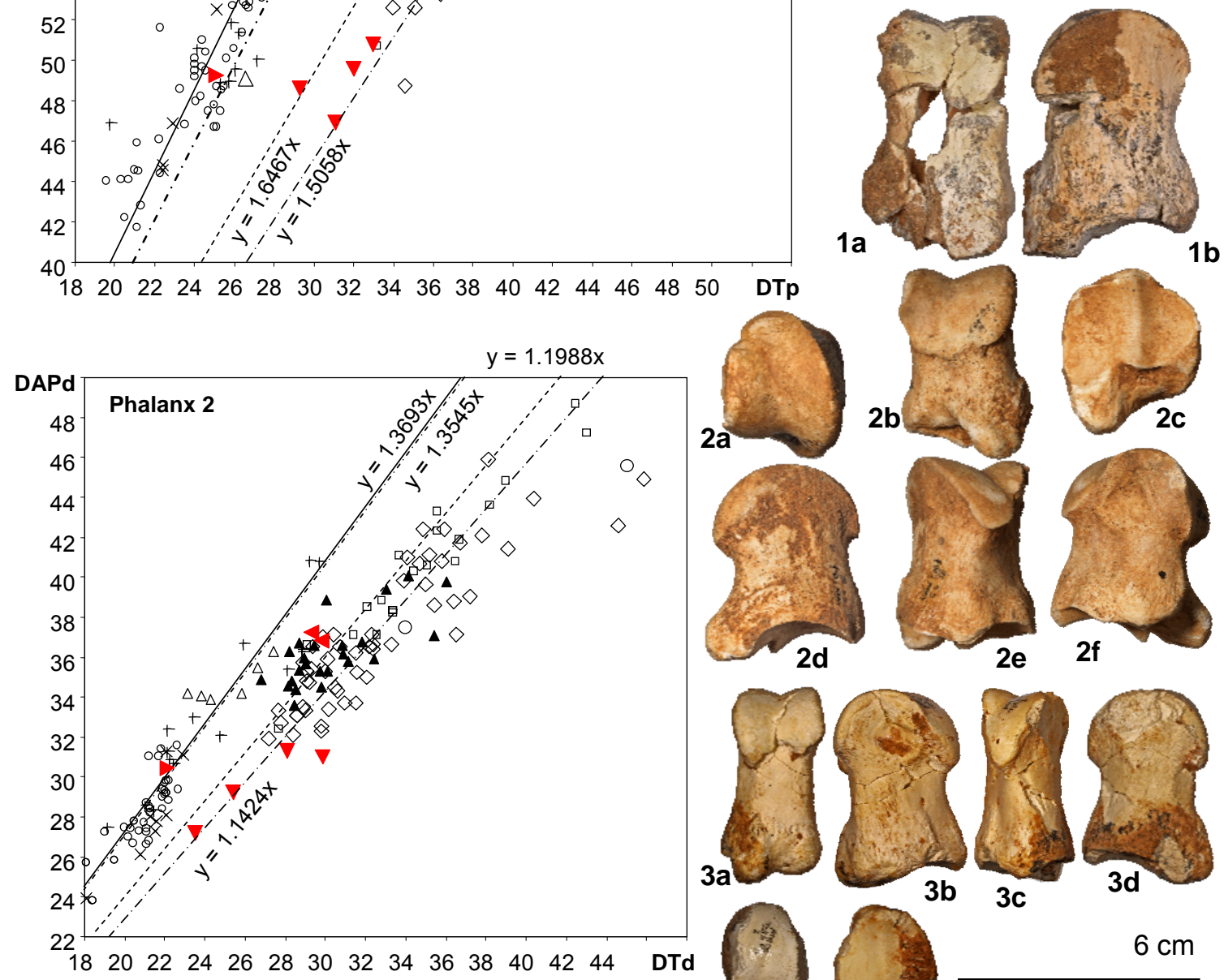

1b
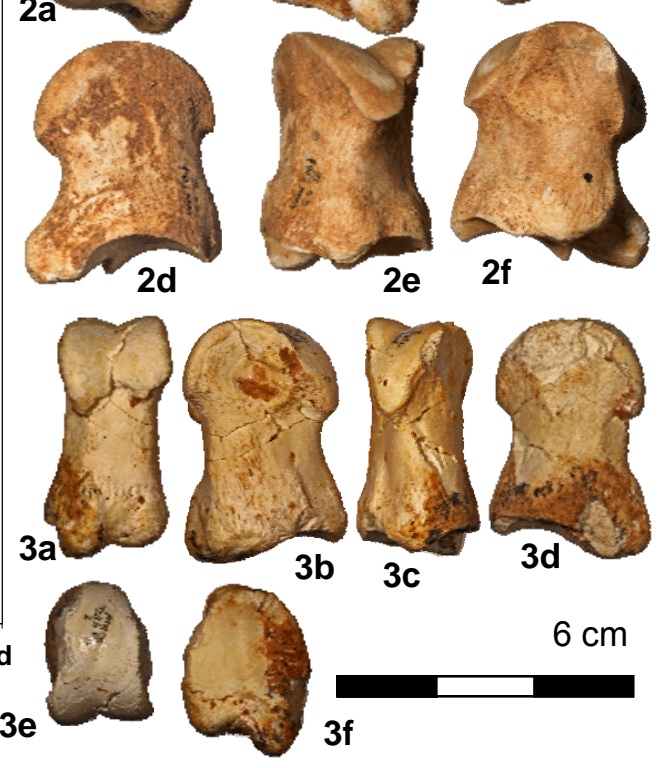

\section{Figure 9}

The second phalanx of the larger ruminants from Atapuerca TD8: 1) Ata06, TD8b, G-3, 71 - left second phalanx of Megaceroides solilhacus: a) plantar, and b) abaxial views. 2) ATA06, TD8b, G-4, 38 - left second phalanx of Bison voigtstedtensis: a) distal, b) plantar, c) proximal, d) axial, e) dorsal, and f) abaxial views. 3) Ata05, TD8b, F-13, 2 right second phalanx of Cervus elaphus: a) plantar, b) axial, c) dorsal, d) abaxial, e) distal, and f) proximal views.

Bivariate diagrams comparing the length (L), proximal width (DTp), distal antero-posterior diameter (DAPd) and distal width (DTd) of the second phalanx of Cervus, Megaceroides and Bison from Atapuerca TD8 to: Cervus elaphus from Azokh V \& VI (MUB) and Neumark Nord (FBFSUJ); Bos primigenius from Miesenheim (Monrepos), Torralba (MNCN), Neumark Nord (FBFSUJ), and Lehringen (HMV); Bison menneri from Untermassfeld (IQW); Bison schoetensacki from Akhalkalaki (IQW), Apollonia 2 (AUT), Konéprusy (NMP), Süssenborn (IQW), West Runton (NHM), Soleilhac (MCP), Blanzac-Soleilhac (NMB), Tsona (GSM), Mauer (SMNK), Bacton (NHM), Mundesley (NHM), Vérteszölös (HGSB), Bilzingsleben (FBFSUJ), and Azokh V (MUB); Bison priscus from Unkelstein (IPRFWUB) and Ortvala Klde (GSM); Eucladoceros giulii and E. aff. giulii from Untermassfeld (IQW) and Akhalkalaki (GSM); Megaceroides from Ubeidiya (HUJ), Cesi (IGF), Voigtstedt (IQW), Süssenborn (IQW), and Soleilhac (MCP); and small Eucladoceros from Tegelen (NBC), Olivola (IGF), and Il Tasso (IGF). 
be between 0.936 and 0.98 Ma (Parés et al., 2013).

There have been marked size changes in European Cervus elaphus (Van der Made, 2001, 2011b; Van der Made et al., 2014). The earliest representatives of this species were large and a large size is to be expected in TD8.

Cervus elaphus is relatively easy to recognize, since it differs in numerous morphological features from Dama dama (Lister, 1996; Di Stefano, 1995b). Several of the Early Pleistocene species of fallow deer size have been assigned to Cervus, by one author or another, but they tend to have Dama morphologies and in any case are clearly smaller. Asian deer like Axis and Rusa share some dental morphologies with Cervus elaphus. Also the early Pleistocene European Cervus perolensis has similarities to the red deer, but is clearly smaller; whether it belongs to this genus is not solved.

The giant deer tend to share many morphological features with Dama, rather than with Cervus. This is also the case with the shape of the lingual wall of the upper premolars. In this feature, the specimen from TD8 differs from the giant deer, it is also smaller than the $\mathrm{P}^{3}$ from Megaceroides and the large Eucladoceros from around the E-M Pleistocene transition. It is larger than the $\mathrm{P}^{3}$ of Cervus perolensis. The premolar and bones fit the red deer. The Cervus elaphus from TD8 is among the oldest from western Europe.

\subsection{Giant deer I}

Genus Eucladoceros Falconer, 1868

Eucladoceros aff. giulii Kahlke, 1997

\subsubsection{Material}

Ata2002, TD8b, G-12, 26 - right $\mathrm{M}_{3}$.

Ata2002, TD8b, G-12, 10 - left $\mathrm{P}^{4}$.

Ata03, TD8b, G-5, 40 - right calcaneum.

? Ata06, Td8b, G-4, 115 - left $\mathrm{P}^{2}$.

? Ata94, TD8, G-16, 19 - left $\mathrm{P}_{3}$.

The measurements of this material are given in Tables 8 \& 9 (supplementary data), along with material of Megaceroides and with material which belongs to one of the two taxa. A taphonomic study assigned 31 fossils to a giant deer, representing a minimum of 2 individuals (Rosell, et al., 2010); part of this material is included here in Eucladoceros and represents at least one individual.

\subsubsection{Description and comparison}

The $\mathbf{M}_{3}$ (Figure 10/1) has relatively smooth stylids on the lingual side, a wide overlap of the metapost- and entoprecristid, there is no ridge connecting these crests (metaendocristid), a clear "step" between the lingual sides of the second and third lobes. These are all features described by Lister (1996) as typical for Dama and different from Cervus, while some other features could not be observed. Such features are also common in Eucladoceros, Megaceroides and Megaloceros. The buccal interlobular column is well developed. The specimen from TD8 is very large and is larger than any $\mathrm{M}_{3}$ of Megaceroides, and the majority of Eucladoceros and Megaloceros species, save for M. giganteus, and is similar in size to material assigned here to Eucladoceros aff. giulii from other levels at Gran Dolina, Akhalkalaki, Apollonia 1 and Lakhuti (Figure 10).

The $\mathbf{P}^{4}$ (Figure 10/2) has a weak postero-lingual cingulum and the lingual wall, if seen from anterior or posterior, is sinuous: near to the base of the crown it is convex and higher up it is concave. These features have been mentioned by Lister (1996) as typical of Dama, and different from Cervus. The tooth is large, close to the upper ranges of Megaceroides, but well within the range of Eucladoceros aff. giulii.

The $\mathbf{P}^{2}$ has a lingual wall with a morphology similar to that described under the $\mathrm{P}^{4}$ and metrically it is also in a similar position.

The $\mathbf{P}_{3}$ has a small and backward placed metaconid, which is not really separated from the protoendocristid. The paraconid and parastylid are well separated in the upper part of the crown. There is no well individualized entoconid, but the crest at this place is transversely oriented and not fused to the metaconid. In some of these features the state is as in the fallow deer in others as in the red deer. In Megaceroides and Eucladoceros, the predominant states are transversely oriented entoconids, that are not connected to the metaconid, but exceptions occur, while well separated paraconids and parastylids are not uncommon (depending on the species). In size, the specimen is large as in Megaceroides and Eucladoceros aff. giulii; it is relatively long for its width, especially compared to Megaceroides.

A calcaneum is large. It is longer than 17 specimens of Megaceroides from Voigtstedt, Süssenborn and Petralona, but is in the range of 13 specimens from Akhalkalaki (AUT) and Apollonia 1 (AUT). 

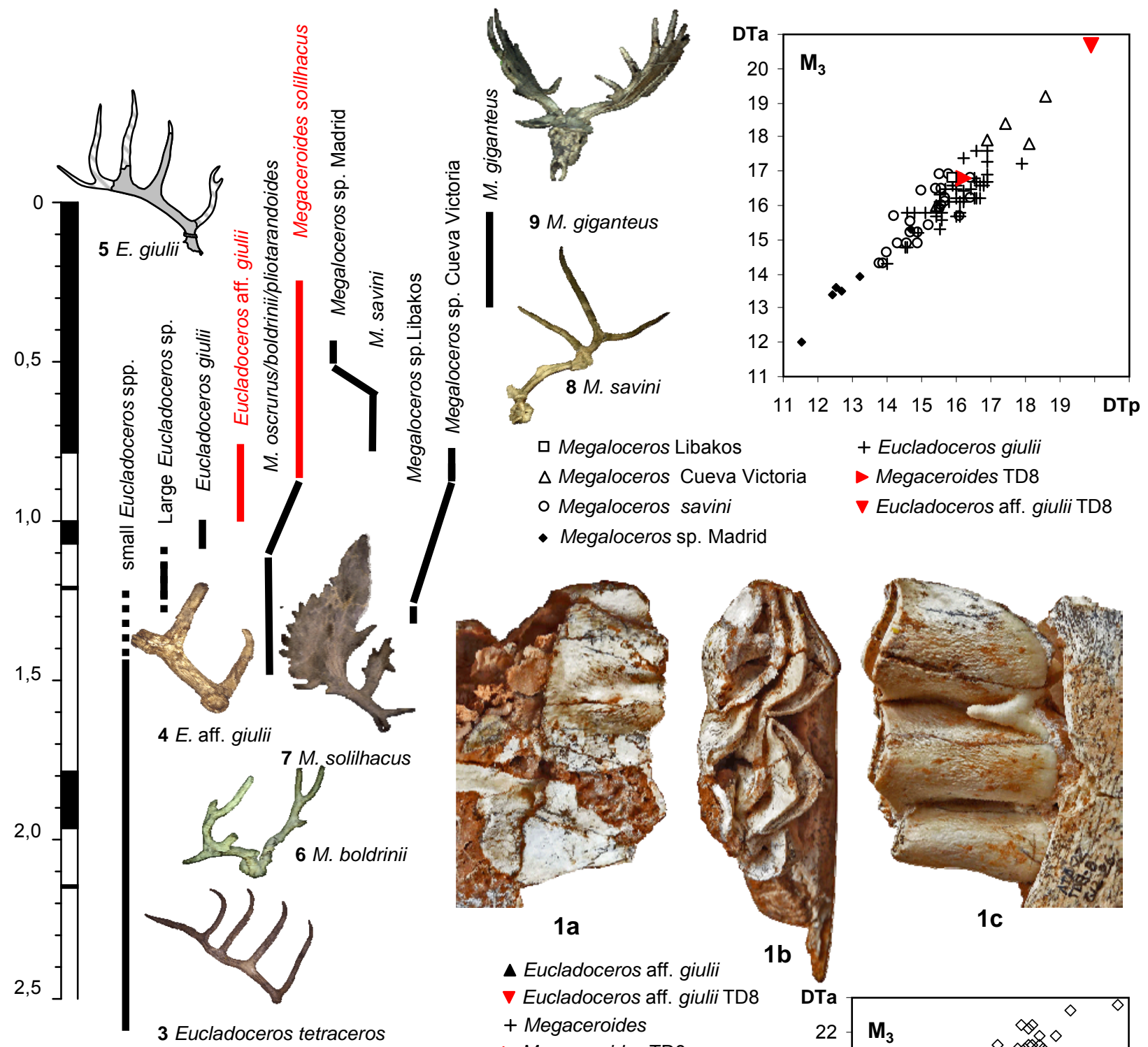

口 Megaloceros Libakos

$\triangle$ Megaloceros Cueva Victoria

- Megaloceros savini

$\checkmark$ Eucladoceros aff. giulii TD8

- Megaloceros sp. Madrid

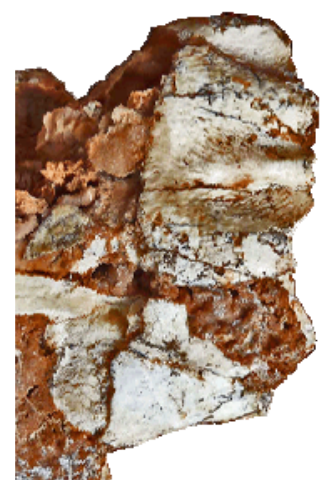

$1 a$

$\Delta$ Eucladoceros aff. giulii

$\nabla$ Eucladoceros aff. giulii TD8

+ Megaceroides

- Megaceroides TD8

$\diamond$ Megaloceros giganteus

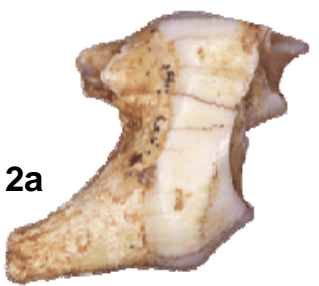

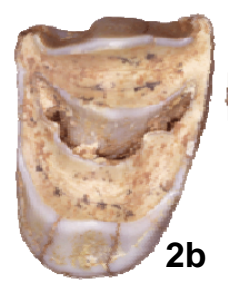

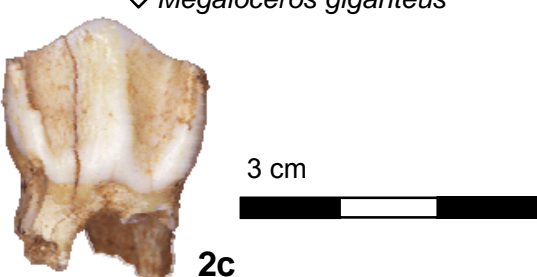

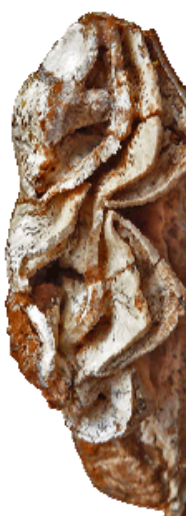

$1 b$

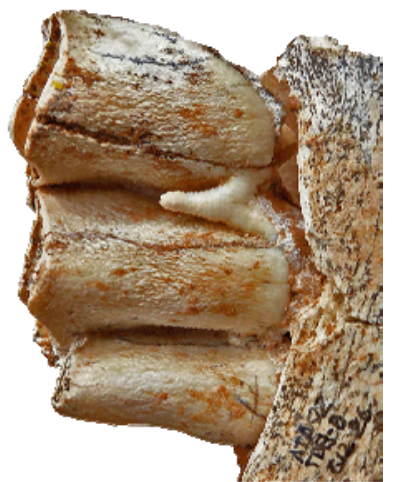

1c

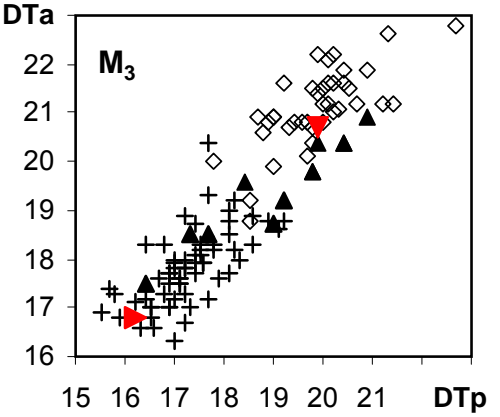

Figure 10

Giant deer from Atapuerca TD8 and other localities: 1) Ata2002, TD8b, G-12, 26 - right M3 of Eucladoceros aff. giulii from TD8: a) lingual, b) occlusal, and c) buccal views. 2) Ata2002, TD8b, G-12, 10 - Left P4 of ?Eucladoceros aff. giulii from TD8: a) posterior, , b) occlusal, and c) buccal views. 3) Eucladoceros tetraceros from Peyrolles: NHM 34409 left shed antler, lectotype, medial view. 4) Eucladoceros aff. giulii from Atapuerca Gran Dolina: ATA90, TD4 left shed antler, lateral view. 5) Eucladoceros giulii from Untermassfeld: reconstruction after H.D. Kahlke (1997). 6)

Megaceroides boldrinii from Aliakmon, NCUA no number, oblique right-anterior view. 7) Megaceroides solilhacus from Soleilhac: MCP no number, left antler, medial view. 8) Megaloceros savini from Süssenborn: IQW 1964/1937, Süss 7075 skull fragment with left antler oblique lateral/inferior view. 9) Megaloceros giganteus from Steinheim: SMNS 15795 skull with antlers (oblique frontal view). The teeth are to scale, the antlers not.

The temporal distribution of the giant deer of the European main land. Conventions as in Figure 5. Bivariate diagrams comparing width of the anterior (DTa) and posterior (DTp) lobes of the M3 of the giant deer from TD8 to: Megaloceros sp. from Libakos (TUC), Cueva Victoria (MAC), and localities in the Madrid area (MSI, MAN, MNCN), Megaloceros savini from Voigtstedt (IQW), Süssenborn (IQW) and Mundesley (NHM); Megaloceros giganteus from Ireland (NHM) and the Rheinschotter (NMM); Megaceroides from Tiraspol (GIN), Voigtstedt (IQW, SMS), Süssenborn (IQW), Soleilhac (MCP), West Runton (NHM), and Mosbach (NMM); Eucladoceros giulii from Untermassfeld (IQW); and Eucladoceros aff. giulii from Akhalkalaki (GSM), Apollonia 1 (AUT), and Lakhuti II (PIN). 


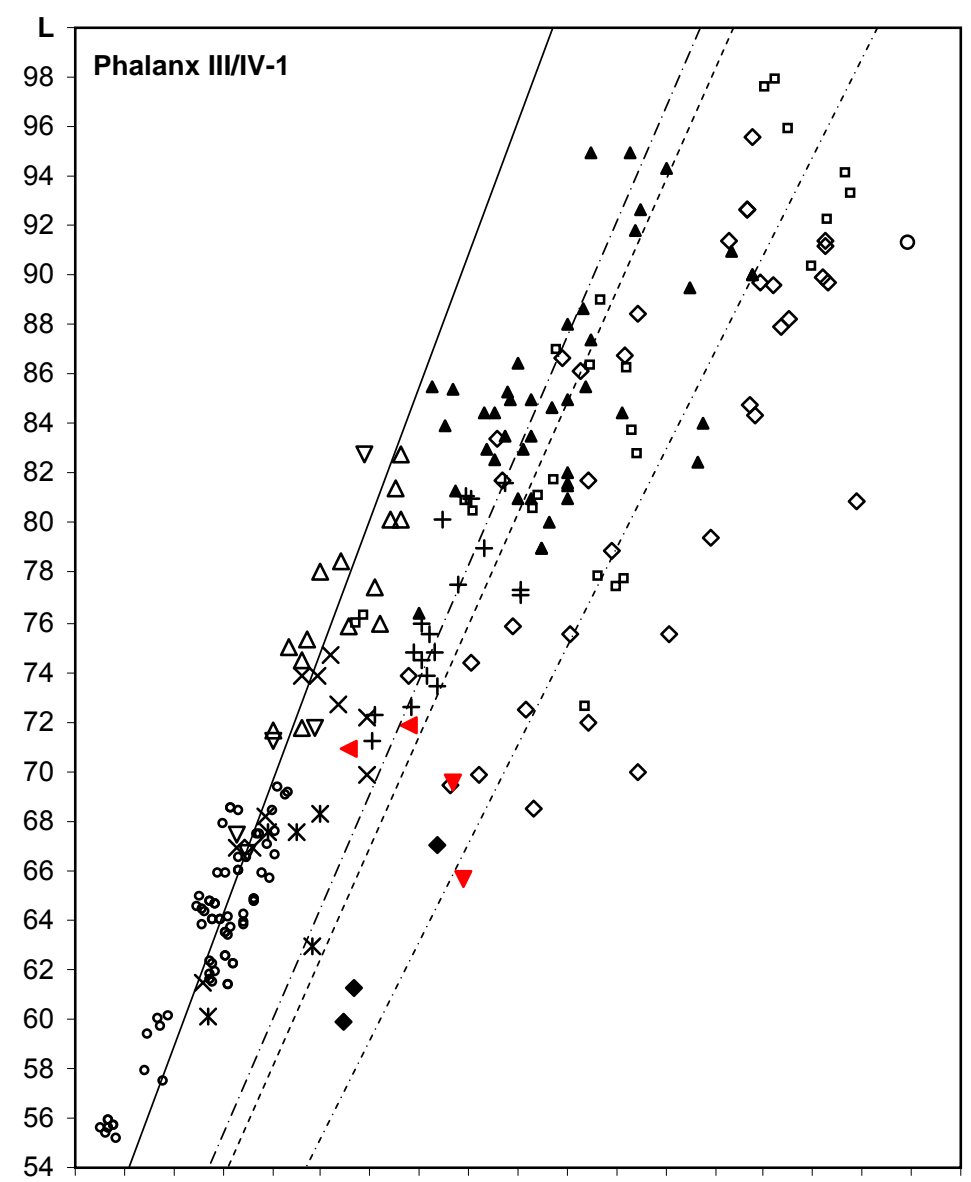

- Cervus elaphus

$\times \quad$ Eucl. tegulensis / dicranios

$\triangle \quad$ Eucladoceros giulii

$\nabla \quad$ Eucladoceros aff. giulii

- Megaceroides TD8

* Megac. boldrinii/pliotarandoides

$+\quad$ Megaceroides solilhacus

- Bison menneri

$\nabla \quad$ Bison voigtstedtensis TD8

- Bison degiulii

$\diamond \quad$ Bison schoetensacki

- Bison priscus

- Bos primigenius

\section{Cervus elaphus $\mathrm{L}=2.6746$ DTp \\ Megaceroides solilhacus $\mathrm{L}=2.3071 \mathrm{DTp}$ \\ Bison menneri $\mathrm{L}=2.2354 \mathrm{DTp}$ \\ B schoetensacki $\mathrm{L}=1.9745 \mathrm{DTp}$}

$\begin{array}{llllllllllllllllll}18 & 20 & 22 & 24 & 26 & 28 & 30 & 32 & 34 & 36 & 38 & 40 & 42 & 44 & 46 & 48 & 50 & \text { DTp }\end{array}$

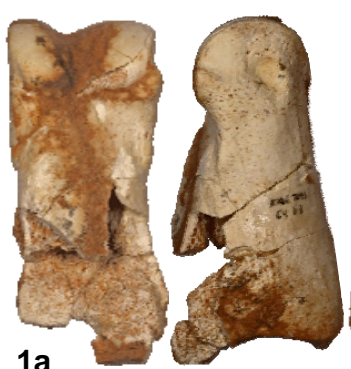

$1 a$

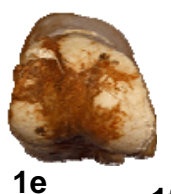

$1 \mathrm{f}$
$1 \mathrm{~b}$

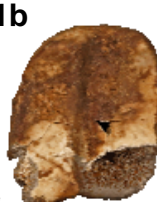

$1 c$


3



$1 d$

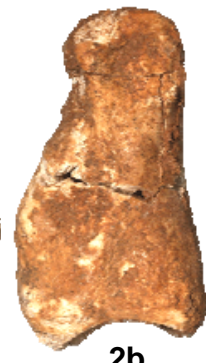

$2 b$

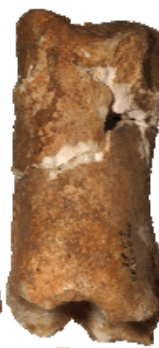

2d

$2 \mathbf{a}$

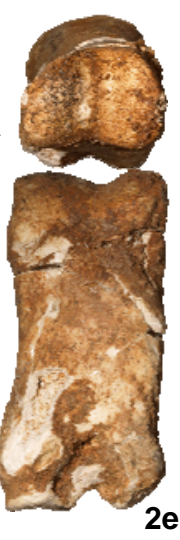

$6 \mathrm{~cm}$

Figure 11

The first and third phalanx of the larger ruminants from Atapuerca TD8: 1) Ata06, TD8b, G-04, 113 - left first phalanx of Megaceroides: a) plantar, b) abaxial, c) dorsal, d) axial, e) distal, and f) proximal views; 2) right first phalanx of Bison: a) distal, b) axial, c) dorsal, d) abaxial, e) plantar, and f) proximal views; 3) Ata04, TD8b, F-14, 10 - right first phalanx of Megaceroides, proximal view; Ata06, TD8b, G-4, 41 - left third phalanx of Bison, proximal view.

Bivariate diagrams comparing the length (L) and proximal width (DTp) of the first phalanges from Atapuerca TD8 with: Cervus elaphus from Neumark Nord (FBFSUJ); Eucladoceros tegulensis from Tegelen (NHMM) and E. dicranios from Il Tasso (IGF); Eucladoceros giulii from Untermassfeld (Kahlke, 1997), Eucladoceros aff. giulii from Atapuerca TD4 and TD7 (MB, IPHES) and Apolonia 1 (AUT); Megaceroides boldrinii from Ubeidiya (HUJ); Megaceroides solilhacus from Voigtstedt (IQW), Süssenborn (IQW), Soleilhac (MCP) and West Runton (NHM); Bison menneri from Untermassfeld (Sher, 1997), Bison degiulii from Pirro Nord (IGF); Bison schoetensacki from Akhalkalaki (GSM), Apollonia 1 (AUT), Süssenborn (IQW), Soleilhac (MCP), Mauer (SMNK), Vérteszölös (HGSB), and Bilzingsleben (FBFSUJ); Bison priscus from Unkelstein (IPRFWUB); and Bos primigenius from Miesenheim (Monrepos), Neumark Nord (FBFSUJ), Lehringen (HMV), and Can Rubau (CIAG). 


\title{
3.6.2. Remarks on context and taxonomy
}

Figure 10 gives the temporal distribution of the giant deer species of the main land of Europe (after Van der Made \& Tong, 2008; Van der Made \& Dimetrijević, in press). Insular species are not considered here. What is indicated here as "small Eucladoceros spp.", includes E. tegulensis, E. senezensis, E. tetraceros and E. dicranios. H.D. Kahlke (1997) named the much younger species Eucladoceros giulii and included in it material from type locality Untermassfeld, and from Würzburg-Schalksberg, Selvella, Pirro Nord, Sainzelles and Venta Micena. Later material from the lower units of Atapuerca Gran Dolina, and Akhalkalaki, Apollonia 1 and Vallonnet was also assigned to this form (Van der Made, 1998a, 1999a; Van der Made et al., 2003). Whereas bones or teeth of these samples are clearly larger than those of the older and "smaller Eucladoceros", these samples are not homogenous and many have teeth that are larger than the teeth of E. giulii (Figure 10), while this is not necessarily true for the bones (eg. Figure 11). This points to different proportions, not just size differences. It seems that E. giulii is from the Jaramillo event (Untermassfeld, Vallonnet), while there is a large form that seems to be older (Venta Micena, Trlica) and another large from that is younger (Atapuerca, Würzburg-Schalksberg, Akhalkalaki, Apollonia 1, and possibly Lakhuti). These three forms share slender metapodials and a generally a large size, the first has an antler with a very high first bifurcation (Van der Made \& Dimitrijević, in press) and the latter species has by far the biggest teeth.

Initially, the material from the lower part of the sequence at Gran Dolina was assigned to Eucladoceros giulii (Van der Made, 1998a, 1999a). This was mainly based on a metacarpal from TD4. In fact there is a similar metacarpal from this or an even older level from an older excavation. The material from TD8 is but few. It has a morphology that is typical of the giant deer in general. The $\mathrm{M}_{3}$ is clearly larger than the majority of the giant deer; it is in the upper range of the large Eucladoceros aff. giulii and well within the ranges of M. giganteus, the largest of all. Though with the few specimens available, it is difficult to formally exclude the latter species, but because of its much younger age, it is unlikely to be present in TD8. The record from the lowermost Middle Pleistocene of TD8 represents the youngest well dated record of Eucladoceros.

According to metacarpal length, the species of TD8 is the tallest species of Eucladoceros (Van der Made \& Dimitrijević, in press, fig. 14). Eucladoceros giulii, of which the skeleton is relatively well known (Kahlke, 1997), is only a little less tall. Megaloceros giganteus had shorter but wider metapodials, while the radius was much longer (Martin, 1987), it must have been taller than any Eucladoceros species and certainly more heavy. The metapodials of Sinomegaceros yabei were nearly as long and robust as those of the species from TD8 (Van der Made \& Tong, 2008, fig. 22). Most species of elk were still larger. In any case, the Eucladoceros species of TD8, was one of the tallest species of deer that ever lived.

\subsection{Giant deer II}

\author{
Genus Megaceroides Joleaud, 1914 \\ Megaceroides solilhacus
}

\subsubsection{Material}

Ata2002, TD8b, G-7, 93 - right mandible with $\mathrm{P}_{2}-\mathrm{M}_{3}$.

Ata2002, TD8b, G-7, 91 - first phalanx, left of the axis of the manus/pes.

Ata06, TD8b, G-04, 113 - first phalanx, left of the axis of the manus/pes.

Ata06, TD8b, G-3, 48 - second phalanx, left of the axis of the foot.

Ata06, TD8b, G-3, 71 - second phalanx, left of the axis of the foot.

? Ata94, TD8, I-17, sc - left astragalus.

? Ata94, TD8, t28, G-17, 4 - left astragalus.

? Ata03, TD8b, G-12, 9 - metacarpal (s/d?), distal part.

? Ata03, TD8b, G-16, 16 - first phalanx, right of the axis of the manus/pes.

? Ata04, TD8b, F-14, 10 - first phalanx, left of the axis of the manus/pes.

? Ata04, TD8b, G-5, removido - metacarpal (s/d?), distal part.

? Ata05,TD8b, H-3, 34 - distal articulation of metapodial (juvenile), right of the axis of the manus/pes.

? Ata05,TD8b, H-3, 49 - distal articulation of metapodial (juvenile), left of the axis of the manus/pes.

The measurements of this material are given in Tables $8 \& 9$ (supplementary data), along with material of Eucladoceros and with material which belongs to one of the two taxa. A taphonomic study assigned 31 fossils to a giant deer, representing a minimum of 2 individuals (Rosell, et al., 2010); part of this material is included or tentatively included here in Megaceroides and represents at least one, tentatively at least two individuals.

\subsubsection{Description and comparison}

The mandible (Figure 12) is badly damaged and its degree of pachyostosis cannot be established; however, all 


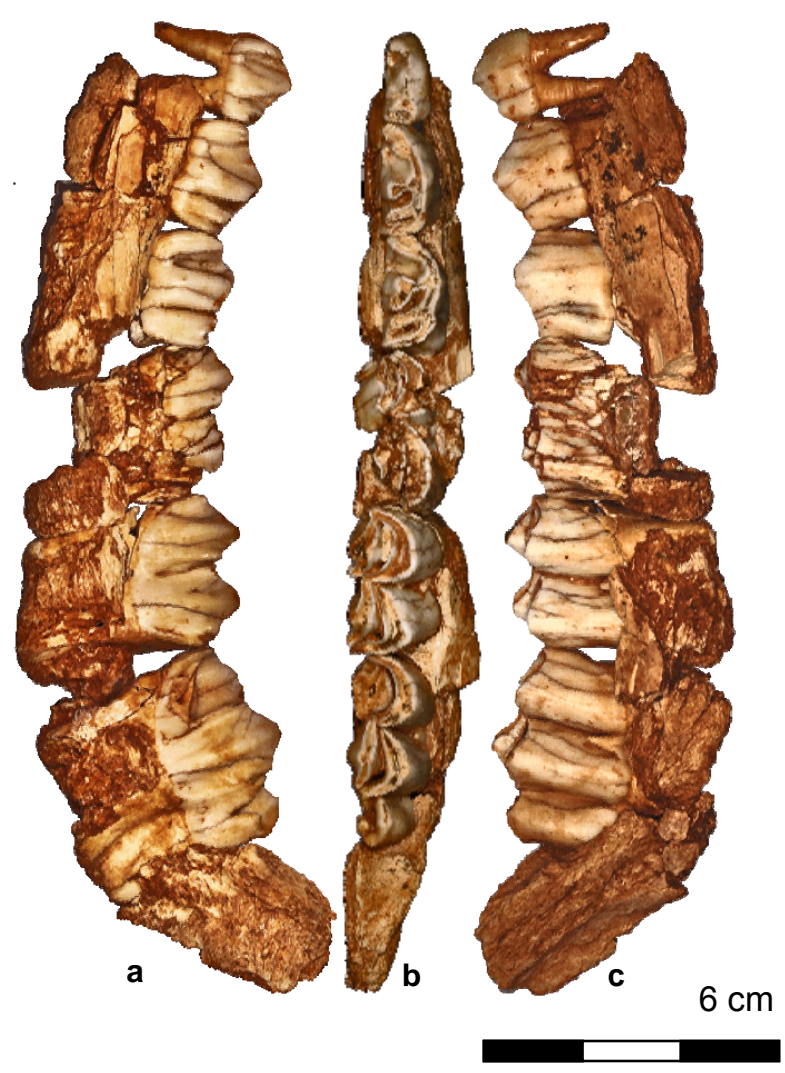

\section{Figure 12}

The right lower cheek teeth of Megaceroides solilhacus from Atapuerca TD8 (Ata2002, TD8b, G-7, G-3): a) lingual, b) occlusal, and c) buccal views. 
cheek teeth are in place.

The $\mathbf{M}_{3}$ (Figure 12) has lingual stylids that are not very strongly developed, no connecting ridge between the ends of the metapost- and entoprecristid (not even near the base of the metaconid, what can be seen very well because this cusp is broken of), there is a faint ridge on the lingual side (feature 12), but no cuspule or cingulum on the lingual side of the third lobe. These are features given by Lister (1996) to separate teeth of Dama and Cervus. In most features, the state is as in Dama, but not in feature 12. The latter feature occurs also in Megaceroides and Megaloceros, but is not common (or does not occur at all) in Eucladoceros. The size of the $\mathrm{M}_{3}$ from TD8 is much smaller than that of the one assigned to $E$. aff. giulii (Figure 7), but it is in the range of $E$. giulii. It is close to the lower range of Megaceroides and the upper of M. savini.

The $\mathbf{M}_{1}$ is in a bad state, but the $\mathbf{M}_{2}$ (Figure 12) has a morphology similar to that of the $\mathbf{M}_{3}$. Whereas the $\mathrm{M}_{3}$ was damaged, here it can be observed that there is only moderate overlap of the metapost- and entoprecristid and there is a "pouch" between the ends of the metapost- and entoprecristid (feature 10), both more typical of Cervus. These two features are a difference with the isolated $\mathrm{M}_{3}$, which is here assigned to Eucladoceros aff. giulii (Figure 10/1).

The $\mathbf{P}_{4}$ (Figure 12) has the entoconid well connected to the hypoconid and oriented more transversely, the lingual opening of the fossid between the entoconid and hypopostcristid is very shallow, no anterior cingulum. These are again Lister's (1996) features and some of them are like in Cervus. The metaconid of the $\mathrm{P}_{4}$ does not have any trace of a metaprecristid and the anterior fossid is wide open lingually; the $\mathrm{P}_{4}$ is not "molarized". A "molarized" $\mathrm{P}_{4}$ has a metaprecristid, which reaches the paraconid and which closes the anterior fossid. The hypoconid sticks out buccally and there is a relatively well developed vertical grove on the buccal side where the protopostcristid reaches the hypoconid.

In the Eucladoceros species that were checked, the ento-hypoconid connection and the alignment of the entoconid in the $\mathrm{P}_{4}$ tends to be different from the TD8 premolar and more like in Dama. In Eucladoceros the molarization is variable, but in E. giulii, the non-molarized type is by far the most common, while in the large $E$. aff. giulii (also present in TD8), this is the other way around. In Eucladoceros, there is well developed grove on the buccal wall and the hypocone sticks out buccally as in TD8. Overall, the specimen from TD8 differs from its homologue in Eucladoceros.

Most Megaloceros species have $\mathrm{P}_{4}$ that are not molarized, but $M$. giganteus has nearly always a molarized $\mathrm{P}_{4}$. Megaloceros giganteus has a grove on the buccal wall and a prominent hypoconid, like in TD8, but in the older species of this genus, the hypoconid is less prominent and the grove is absent. In one way or another the $\mathrm{P}_{4}$ of the Megaloceros species differ from the one from TD8.

In the Megaceroides samples checked, the entoconid morphology of the $\mathrm{P}_{4}$ is variable and sometimes is more "Dama-like" than in the specimen from TD8. The hypoconid and its preceding vertical grove on the buccal wall are well developed. In the Megaceroides sample from Süssenborn, which is only slightly younger than TD8, the $\mathrm{P}_{4}$ is predominantly non-molarized, but the younger samples tend to have molarized premolars. The $\mathrm{P}_{4}$ from TD8 fits thus best the somewhat older samples of this genus.

The $\mathbf{P}_{3}$ (Figure 12) has the entoconid fused to the hypoconid and transversely oriented. The paraconid and parastylid are not well separated. The lingual opening of the posterior fossid is shallow. These morphologies predominate in the giant deer.

The $\mathbf{P}_{2}$ (Figure) has a moderately high crown, but its buccal wall is not as flat as in Cervus. The parastylid is very well developed, but there is no trace of a paraconid. In Eucladoceros giulii, often a small paraconid is developed and this also tends to be the case in Megaloceros.

Some first phalanges (Figures 11/1, 11/3) are robust and similar in size to some phalanges from TD8, that are assigned here to Bison (Figure 11/2 and bivariate diagram). These phalanges have the following features described by Heintz (1970) for separating Bovidae and Cervidae: a rectangular facet for the abaxial sesamoid (feature a), in proximal view no deep fossa in the middle below the proximal articular surface (feature b), no clear proximo-axial tuberosity on the dorsal surface (feature d), while it is not clear what was meant with feature c. Features a and c are as in Bovidae and b is as in Cervidae. However, other features might serve to separate these phalanges from those of the Bovini (including Bison). The first phalanges from TD8 have a distal articular surface that is relatively high and narrow. If seen from distal, the lower edge of this surface slopes from the furrow in the middle downwards towards the axial and abaxial borders. In the Bovini, this surface is lower and its lower edge frequently curves up near the axial and abaxial edges. The furrow in the middle of the distal facet is sharp, while in the Bovini it appears more wide (open V-shaped against U-shaped). Where preserved, the facets for the sesamoids are well developed. In the Bovini, these tend to be low and may be very badly developed. At the axial side of the plantar surface, there is a relatively well developed crest. Such a crest is usually more prominent in the Bovini than in the Cervidae. There is much variation in the proportions and size of the bison phalanges. In general, Bison menneri has phalanges that are larger and on average more robust than in the giant deer, and those of Bison degiulii and Bison schoetensacki and especially those of Bison priscus are still 
more robust. In all, the morphology looks more cervid.

The first phalanges, in which length could be measured, are more robust than in Eucladoceros, but correspond to the proportions and size in Megaceroides solilhacus (Figure 9).

The second phalanx (Figure 9/1) is in a bad state, but what is left of the proximal articular surface is high. If seen from the proximal side, the plantar-axial process is not reduced as in bovids and there is no clear gully on the middle of the post articular plateau (features of Heintz, 1970). In general, the post articular plateau projects more proximally. This morphology is more like in Cervidae than in Bovidae. For a cervid, the two more complete second phalanges look very stout and this is confirmed by the measurements. The distal articular surface is wide and both specimens are in the overlap of Bison menneri, the most gracile bison, and Megaceroides, one of the most robust deer (Figure 9). Compared to the length, again the width is great. Especially length and distal width are much larger than the specimens of Eucladoceros, with which they are compared here. The sample of Bison menneri forms two clusters, which could be interpreted as phalanges of the pes and manus. Similarly, the specimens from TD8, assigned here to a giant deer, could be interpreted as phalanges of the pes of Bison, while four other specimens from TD8, assigned to Bison, could be interpreted as being from the manus. However, if this were the case, the range of variation of the length of the phalanges from TD8 would be much greater than that of $B$. menneri. All this points to the larger phalanges from TD8 to belong to Megaceroides.

The astragalus is represented by two specimens. They are tentatively included in this species, because they are in the lower metrical range of twelve specimens of the large Eucladoceros aff. giulii from Akhalkalaki (GSM) and Apollonia (AUT) and in the ranges of over thirty specimens of Megaceroides from Süssenborn (IQW) and Petralona (AUT).

\subsubsection{Remarks on taxonomy and evolution}

Different opinions have been published on the systematics of Megaceroides. Such deer have been placed in Megaloceros (e.g. Azzaroli, 1953; Lister, 1993; Van der Made, 2001), in Praemegaceros (e.g. Kahlke, 1965b, Vislobokova, 1990) or in Megaceroides (Azzaroli \& Mazza, 1992; Abbazzi et al., 1999), but after Hadjiouis (1990) argued that type species of Megaceroides algericus is not related to the European species, these have been placed predominantly in Praemegaceros (e.g. Croitor, 2006; Pfeiffer, 1999; Abbazzi \& Lacombat, 2005). It is not the intention to discuss this issue here, but the widened pedicle is a synapomorphy of M. algericus and the European species of this genus and separates the genus from other giant deer.

The number of species in this genus from the European mainland is another issue. Possibly most species are recognized by Croitor \& Kostopoulos (2004) and Croitor (2006): three subgenera with five continental species, having overlapping temporal and geographic ranges. Croitor (2011) presented a model in which initial vicariant speciation occurred and in which later differences in antler morphology account for different ecologies causing reproductive isolation of three different lineages, so that three species could co-exist in the same locality. Generally several species are recognized (Vislobokova, 1990; Lister, 1993; Abbazzi, 1995; Delpech \& Guérin, 1996). See also the discussion on synonymies by Vislobokova (2012).

Excluding the insular endemics, Megaceroides is the genus that shows least morphological and metrical variation of all the giant deer. The main differences are found in: 1) the progressive reduction of the brow tine, from large to a little knob and completely absent; 2) a later reduction of the second tine; 3) the distal part of the antler is branching in the older samples and palmate in the geologically younger samples (Azzaroli, 1953; Azzaroli \& Mazza, 1993; Abbazzi, 1995; Croitor, 2006). The reduction of the second tine lags behind the reduction of the brow tine (when the brow tine is small or completely gone, the second tine still tends to be relatively large), and the appearance of the distal palmation is very imprecisely documented, but is always found in antlers with very small or no brow tines. There are few or no publications comparing the postcranials of the different forms, but maybe the earliest representatives of the genus were smaller. Megaceroides is taken here as having a primitive species with a large brow tine and a branching antler (known under the names: $M$.

pliotarandoides, $M$. obscurus, $M$. boldrinii), and a more evolved species with a browtine that is reduced to a small knob or that is lacking all together, and with a distal palmation (for which M. solilhacus is the oldest name) (Van der Made, 2015).

Material from the lower part of the Gran Dolina sequence has been previously assigned to Praemegaceros sp. by Azanza \& Sánchez (1990) and to Megaloceros solilhacus (Rodríguez et al., 2011). The latter identification is based in part on the tooth row, which is described here. As appears from the description and comparison, the cheek teeth show morphological and metrical differences with the species of Megaloceros and Eucladoceros. The first and second phalanges are robust as in Megaceroides and differ in this from Eucladoceros. As far as known the earlier Megaloceros species had gracile metapodials (Van der Made \& Tong, 2008) and first phalanges. The bones and teeth described in this section belong to a large deer, but differ in size from the smaller Eucladoceros species and from Megaloceros spp. from Madrid and from Cueva Victoria. The 
material from TD8 is assigned here to Megaceroides.

Material from a not specified level of the sequence at Gran Dolina has lost the brow tine completely by reduction (Azanza \& Sánchez, 1990, Pl. 1, fig. 1). This specimen is likely to have come from the lower part of the section, units TD3/4 to TD8, being collected in the 1980'ies, most probably from TD3/4. This morphology is typical of the evolved Megaceroides, here all included in $M$. solilhacus. This antler fragment allows to assign the material from TD8 to that species, even though antler material is lacking so far from TD8.

\subsection{Fallow deer}

Genus Dama Frisch, 1775

Dama vallonnetensis (De Lumley, Kahlke, Moigne \& Moullé, 1988)

\subsubsection{Material}

Ata03, TD8b, G-5, 44 - the basal part of a left antler. The antler is shed.

$\mathrm{Al}$ other bones and teeth studied here, about 400 fossils, are listed in Tables 10-27 (supplementary data). A taphonomic study assigned 615 fossils to the fallow deer, representing a minimum of 16 individuals (Rosell, et al., 2010).

\subsubsection{Description and comparison}

Of the antler (Figure 13/1), only the base is preserved. The antero-posterior diameter of the burr (DAPr) is 35.0 $\mathrm{mm}$, the same diameter just above the burr (DAPb) is $\geq 43.8 \mathrm{~mm}$ and the height of the bifurcation is $33.7 \mathrm{~mm}$ measured from below the burr and $29.3 \mathrm{~mm}$ from the upper surface of the burr (Hext and Hext'; measured at the lateral side). There is a large angle between the brow tine and main beam. The bifurcation between the brow tine and main beam is low in absolute terms and expressed as the index $100 \mathrm{x}$ Hext / DAPb $=96$. This value is lower than those of the antlers from TD4-6 and is comparable to those from Vallonnet, Untermassfeld, and Atapuerca TE7 (Figure 13). In general, this value decreased in the Dama-like deer, but the samples from Atapuerca TD4-6, Ponte Galeria, have high values for their age. It seems that in the samples with high values, it is the ontogenetically younger individuals that have the highest values.

The $\mathbf{M}_{3}$ (Figures 14/1-2, 14/4, 15/1-2) has the lingual stylids moderately developed, the anterior fossid usually opens lingually and is not blocked by a little crest (metaendocristid), there is no very pronounced depression on the lingual wall between the bases of the entoectostylid and metapoststylid, there is a clear step in the lingual wall between the second and third lobes, there is no cingulum on the lingual side of the third lobe. These are all features described by Lister (1996) and they are all developed as in Dama and not as in Cervus.

Another feature mentioned by Lister (1996) is a vertical crest on the lingual wall of the third lobe, which is often clear in Cervus and weak or absent in Dama. In the fossils from TD8, this feature is as in Dama. The feature might be related to the pattern of the occlusal surface (Figures 15/3-7). There are marked differences in the way the crests at the junction of the second and third lobes connect to each other. With progressive wear, more crests become connected, but there are differences in the order in which the connections are formed. A little cusp, called hexaconid (Figure 15/3), is usually present, but becomes connected to one of the main crests early (usually to the forwards curving pentaendocristid) and from then onwards it is not seen as a distinct cusp. Bovidae often lack such a cusp, but there is also a rare example from TD8 (Figure 14/4). In the Capreolinae (Capreolus, Alces, Rangifer), the hexaconid tends to be well developed and may connect early to the entopostcristid, while the hypoendocristid does not reach far lingually, but may connect to the pentaprecristid. As a result the fossids of the second and third lobes may be connected (Figure 15/5). In the Cervinae this does not occur and the hypoendocristid connects first to the entopostcristid (Figure 15/4) or pentaendocristid (which curves forward and incorporates the hexaconid) (Figure 15/7). There is variation in the length and orientation of the hypoendocristid, which may be directed towards the hexaconid or anteriorly curved pentaendocristid and connect first to this structure (Figures 15/7, 15/2) or be long and reach the lingual wall (Figure 15/4) or be long and reach the lingual wall, fusing to the entopostcristid (Figures 15/4, 14/4). The situation in which the hypoendocristid is short and directed posteriorly (Figure 15/1), as is more common in the Capreolinae, is less common. In this specimen also the pentaendocristid fuses to the hexaconid and thus to the pentaprecristid, closing the pentafossid, and remaining isolated from the hypoendocristid (Figure 15/1 and 15/6). A long hypoendocristid directed towards the anterior end of the pentaendocristid and reaching the lingual wall might be related to Lister's (1996) vertical crest on the lingual wall (feature 12) and be more typical of Cervus and related taxa. In this case the vertical crest is an expression of the hypoendocristid reaching the lingual wall posterior of the end of the entopostcristid or of a more posteriorly positioned hexaconid, which connects the hypoendocristid and pentaendocristid. Though there is variability in the different samples, the predominant way these crests connect to each other might be different in the different Cervinae. More work on this feature is needed. 


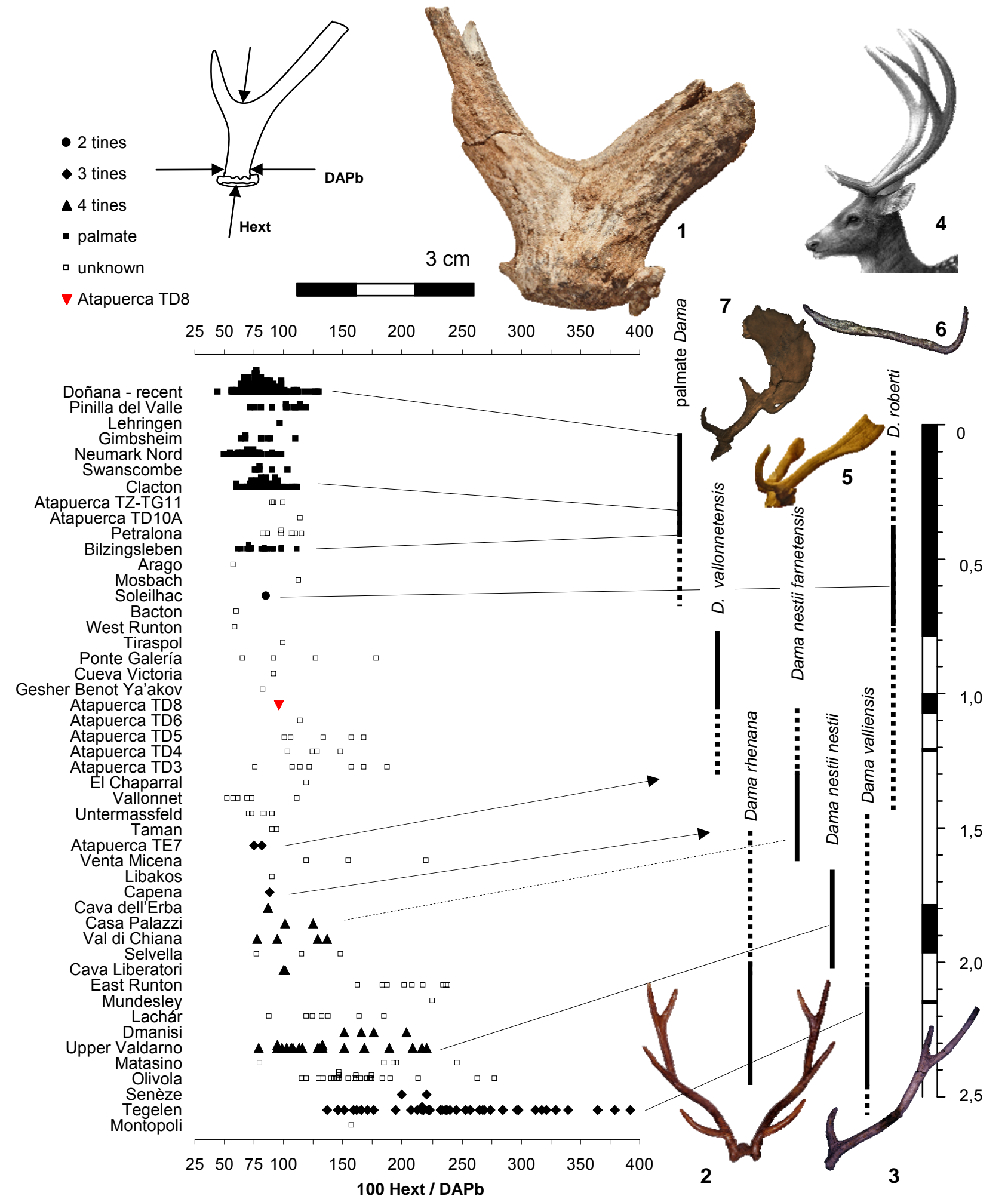

Figure 13

The antlers of the Dama-like deer. 1) Ata03, TD8b, G-5, 44 - the basal part of a left shed antler of Dama vallonnetensis from Atapuerca TD8. 2) IGF363 - skull fragment with two antlers of Dama nestii, type from the upper Valdarno: frontal view. 3) NBC St28148 - left antler of Dama rhenana from Tegelen: lateral view. 4) Reconstruction of Dama from Atapuerca TE9 by Eduardo Saíz. 5) NCM 2004.831.13/14 - skull fragment with both antlers, holotype of Dama robertorum, from Pakefield: oblique left view. 6) MCP Sol 2003-4-390 right antler of Dama from Soleilhac: lateral view. 7) FBFSUJ 27/6/89-13 - right antler and skull fragment of Dama dama geiselana from Neumark Nord: medial view. Figures 2-7 not to scale. The temporal distributions of the different west European species of Dama-like deer, indicated as thick lines, dashed in the case of tentative distributions. The scale applies to photograph 1; other photographs not to scale.

The position of the bifurcation of brow tine and main beam above the burr, indicated as the index $100 \mathrm{Hext} / \mathrm{DAPb}$ in the following samples: Montopoli (IGF), Tegelen (NBC, NMMa, TMH), Senèze (IQW), Olivola (IGF), Matassino (IGF), Upper Valdarno (IGF), Dmanisi (GSM), Láchar (MNCN), Mundesley (NHM), East Runton (NHM), Cava Liberatori (IGF), Selvella (IGF), Val di Chiana (IGF), Casa Palazzi (IGF), Cava dell'Erba (IGF), Capena (DSTUSR), Libakos (TUC), Venta Micena (IPS), Atapuerca TE7, TDW3-4, TDE5, TD6, TZ, TG11, TD10 (MB, CENIEH, IPHES), Taman (PIN), Untermassfeld (IQW), Vallonnet (MPRM), El Chaparral (XXX), Gesher Benot Ya’akov (HUJ), Cueva Victoria (MAC), Ponte Galeria (DSTUSR), Tiraspol (GIN), West Runton (NHM), Bacton (NHM), Soleilhac (MCP), Mosbach (IQW), Arago (LPT), Bilzingsleben (FBFSUJ), Petralona (AUT), Clacton (NHM), Swanscombe (NHM), Neumark Nord (FBFSUJ, now in LVH), Gimbsheim (NMM), Lehringen (HMV), Pinilla del Valle (UCM, presently MAR), recent Dama dama from the Doñana national park (EBD). 



Figure 14

The dentition of Dama vallonnetensis from Atapuerca TD8. 1) Ata06, TD8b, G3, 62 - right mandible with P2M3: a) lingual, b) occlusal, and c) buccal views. 2) Ata06, TD8b, G4, 126 - left mandible with P2-M3: a) buccal, b) occlusal, and c) lingual views. 3) Ata02, TD8b, G10, 26 - left M2: a) lingual, b) occlusal, and c) buccal views. 4) Ata02, TD8b, G11, 14 - left M2-3: a) buccal, b) occlusal, and c) lingual views. 5) Ata02, TD8b, G8, 44 - left P4: a) lingual, b) occlusal, and c) buccal views. 6) Ata02, TD8b, G7, 12 - right M3: a) buccal, and b) occlusal views. 7) Ata05, TD8b, H3, 33 - right P3-4: a) lingual, and b) occlusal views. 8) Ata02, TD8b, G8, 16 - left P3: a) lingual, b) occlusal, and c) buccal views. 9) Ata02, TD8b, G13, 18 - right M3: a) occlusal, b) buccal, and c) anterior views. Upper scale: figure 1; left lower scale: figures 3, 5 \& 8; right lower scale: figures 2, 4, 6,7 \& 9. 


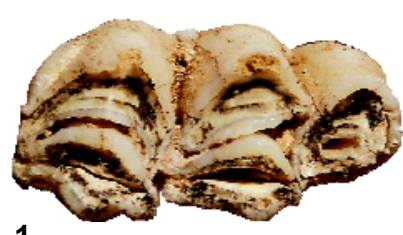

1


(hexaconid)

$$
\delta \mathrm{O}^{18}(\%)
$$

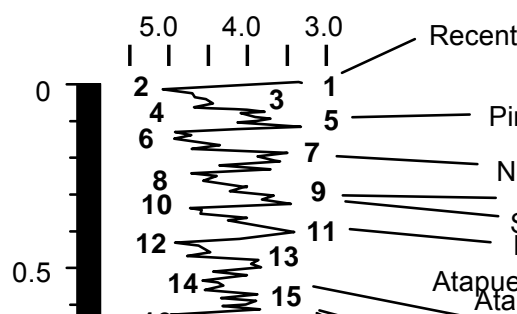

9

9 Can Ragnar Pinilla del valle Neumark Nord Orgnacry Swanscombe rca THalona
2

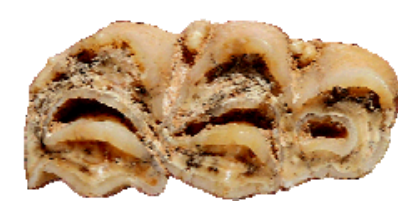

$3 \mathrm{~cm}$

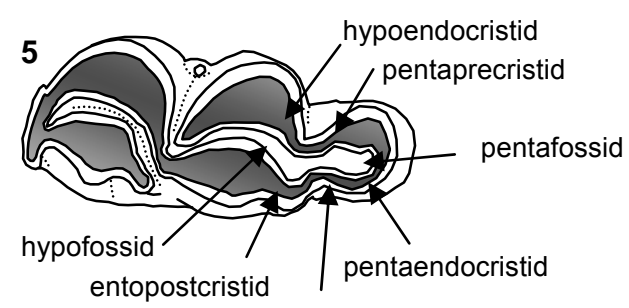

(hexaconid)

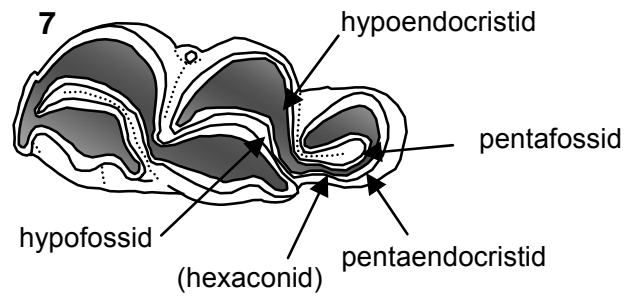

10

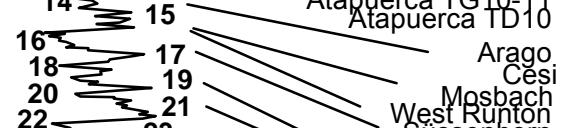

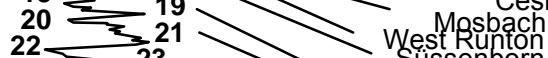

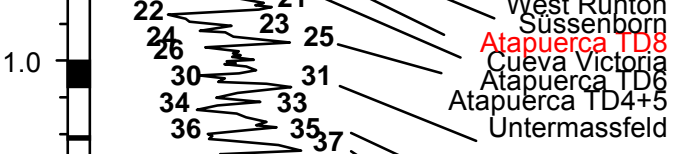

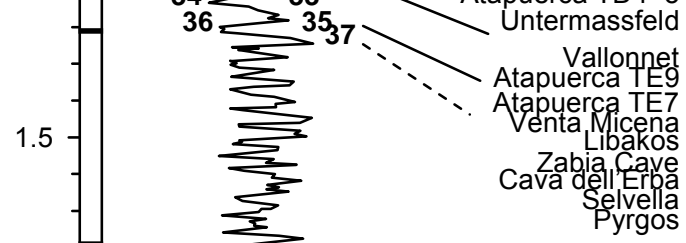
U Valdarno Casablanca 1 Olivola 11 $12 \quad 13$ $14 \quad$ DTa
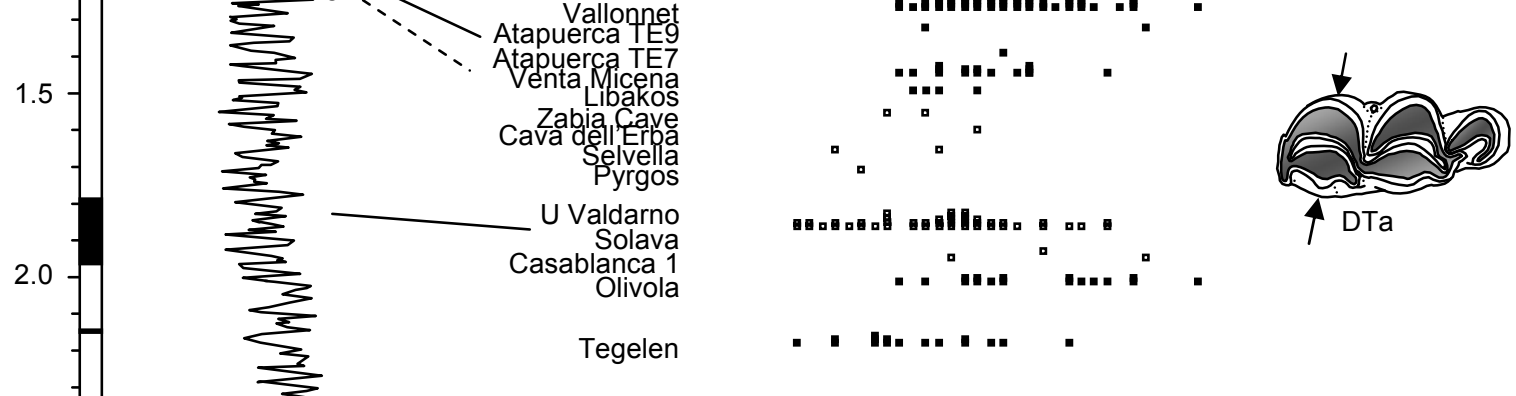

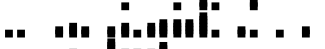

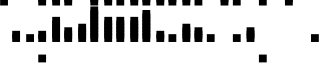

Montopoli

9

Figure 15

The M3 of Dama vallonnetensis: 1) Ata05-TD8b-F13-15 - right M3, occlusal view; 2) Ata05-TD8b-F13-17 - right M3, occlusal view. Schematic representation of different morphologies of the third lobe of the M3, occlusal view: 3-7.

The width of the first lobe (DTa) of the M3 of the Dama-like deer, as indicative of general size from: Montopoli (IGF), Olivola (IGF), Tegelen (NNML, TMH, NMMaa), Casablanca 1 (SIAP), Solava (IGF), Upper Valdarno (incl. Il Tasso \& Casa Frata; IGF), Pyrgos (IVAU, presently NCUA), Selvella (IGF), Cava dell’Erba (IGF), Zabia Cave (ZPALUWr), Libakos (TUC), Venta Micena (Menéndez, 1987), Atapuerca TE7 \& TE9 (CENIEH, IPHES), Vallonnet (MPRM), Untermassfeld (IQW), Atapuerca TD4+5, TD6 \& TD8 (CENIEH, MB, IPHES), Cueva Victoria (MAC), Süssenborn (IQW), West Runton (NHM), Cesi (IGF), Mosbach (NMM), Arago (LPT), Atapuerca TD10 \& TG10-11 (MB, IPHES), Petralona (AUT), Bilzingsleben (FSBFSUJ), Swanscombe (NHM), Orgnac 3 (LPTUP), Murr (SMNS), Neumark Nord (FSBFSUJ, presently LVH), Gimbsheim (NMMai), Pinilla del Valle (UCM, presently MAR), Can Rubau (CIAG), Taglar (MUB), Dahne (MNHUB), Spain Recent (MNCN). 
The size of the $\mathrm{M}_{3}$ in the different samples of Dama is compared in Figure 15. This is probably the most common fossil and since there are no very important differences in proportions in the tooth row, it can be taken as an indication of gross size. It can be seen that the earliest samples indicate a relatively large average body size, then size decreased towards $1.4 \mathrm{Ma}$, followed by an increase towards $0.4 \mathrm{Ma}$, followed again by a size decrease. The sample from TD8 fits within the ranges of Vallonnet and Untermassfeld, but is on average a little smaller than those from TD6 and TD4+5, and those of the samples commonly assigned to Dama clactoniana.

The $\mathbf{M}_{1}$ and $\mathbf{M}_{2}$ (Figures 14/1, 14/2, 14/3, 14/4) have morphologies that are similar to those described under the $\mathrm{M}_{3}$ (save for that they lack a third lobe). The anterior fossid usually opens lingually and is not blocked by a little crest (metaendocristid), but occasionally the entoprecristid is longer than usual and reaches the metapostcristid, closing the anterior fossid (Figure 14/3b).

The $\mathbf{P}_{4}$ has an entoconid that may be aligned transversely and be connected with the hypoconid (Figures $14 / 1,14 / 2,14 / 5$ ) or be aligned antero-posteriorly and be disconnected from the hypoconid, but fused to the metaconid (Figure 14/7). The posterior fossid (hypofossid) is not closed on the lingual side, but has a deep opening there. Each time, the latter state is common in Dama, but rare or absent in Cervus (Lister, 1996). The tooth may have a well developed metaprecristid closing the anterior fossid (protofossid) on the lingual side (Figures 14/1, 14/2, 14/7), or may completely lack this structure (Figure 14/5). These states are called "molarized" and "non-molarized” respectively. The latter state is primitive. In many species this feature is variable; in Cervus elaphus from Ehringsdorf (IQW) the proportion not molarized/molarized is 6/21 and in Bilzingsleben it is 7/70 (FBFSUJ). In the old and primitive Dama rhenana from Tegelen this is 12/0 (NBC, NMMaa, TMH), while in Dama nestii from the Upper Valdarno (IGF) this is 7/24, in Dama from Venta Micena it is 10/3 (IPS) and in Dama vallonnetensis from Vallonnet and Untermassfeld this is 2/12 (MPRM) and 7/47 (IQW), respectively, and in the still younger and“more progressive” Dama clactoniana from Arago (LPTUP) and Swanscombe (NHM) this is 10/45 and 5/7, respectively, while in Dama dama from Neumark Nord and Pinilla del Valle-Camino, this is 30/30 and 10/16 (FBFSUJ, presently LVH; UCM, presently MAR). In TD8 this is $8 / 7$, which is thus clearly less than in the red deer, the deer from the Upper Valdarno and all younger Damalike deer, but more than in Dama rhenana and the deer from Venta Micena.

The $\mathbf{P}_{3}$ (Figures 14/1, 14/2, 14/7, 14/8) has the paraconid and parastylid well separated as in Dama, while in Cervus this is often not the case (Lister, 1996). The entoconid tends to be oriented transversely and be connected to the hypoconid. The hypofossid is wide open lingually.

The $\mathbf{P}_{2}$ (Figures 14/1, 14/2) has a relatively low crown, a convex buccal wall and the lingual wall at the place of the protoconid recedes clearly. This is as in Dama, while in Cervus, Rusa and Axis, the crown is higher with flatter lingual and buccal walls. The protoprecristid curves lingually in its distal part, forming what is usually called the parastylid and paraconid, which is as in Dama, while in Cervus, Rusa and Axis, this lingual curvature is less marked and not bifurcated in its distal part.

The $\mathbf{M}^{\mathbf{1} / 2}$ and $\mathbf{M}^{3}$ (Figures 14/6, 14/9) have relatively weak buccal styles, especially the metaecto- and metapoststyles, as in Dama, while in Cervus, but also in Rusa and Axis, these styles tend to be much stronger. These features are as in Dama and differ from the state in Cervus (Lister, 1996). Like in Dama, the lingual interlobular column and associated cingulum are weakly developed, whereas these are better developed in Axis and much better in Rusa and Cervus (features of Lister, 1996).

The $\mathbf{P}^{4}, \mathbf{P}^{3}$ and $\mathbf{P}^{2}$ have, in anterior or posterior view, the profile of the lingual wall convex in the lower part and concave in the upper part, as is common in the Dama-like deer, while in Cervus it is more straight or slightly convex (feature 3 of Lister, 1996).

The metacarpal (Figure 16/1) is an interesting bone for its proportions. Some species have robust and others have gracile metapodials. Figure 16 compares the size and proportions of the metacarpals of the earlier species and gives the large sample of Dama dama geiselana from Neumark Nord as an example for the variability. The lines indicate the average proportions of the different species. The deer from TD8 has gracile metapodials, like those of Dama vallonnetensis and un-like those assigned to Dama robertorum (= D. roberti Breda \& Lister, 2013 - see end of section 3.8.3.) and those of Dama nestii.

The first phalanx (Figure 16/2) is represented by many specimens (Table 24). Lister (1996) indicated one feature to separate red and fallow deer phalanges. In the middle of the proximal side and plantar of the central furrow, there is a proximally facing area of bone in Cervus, while in Dama it is lacking. The latter morphology is found in TD8. The differences in proportions of the metacarpals, suggests, that similar differences could be found also in the phalanges. On average, there are some differences, but they are not so clear (Figure 16). This might be due to the fact that posterior phalanges tend to be more elongate than the anterior ones, and they have not been separated. The anterior and posterior phalanges tend to differ in proportions and morphological features, but there is a continuum of morphologies and a reliable separation is not possible, or difficult at least.

The astragalus has, in anterior view, the medial edge of the proximal articular surface projecting 


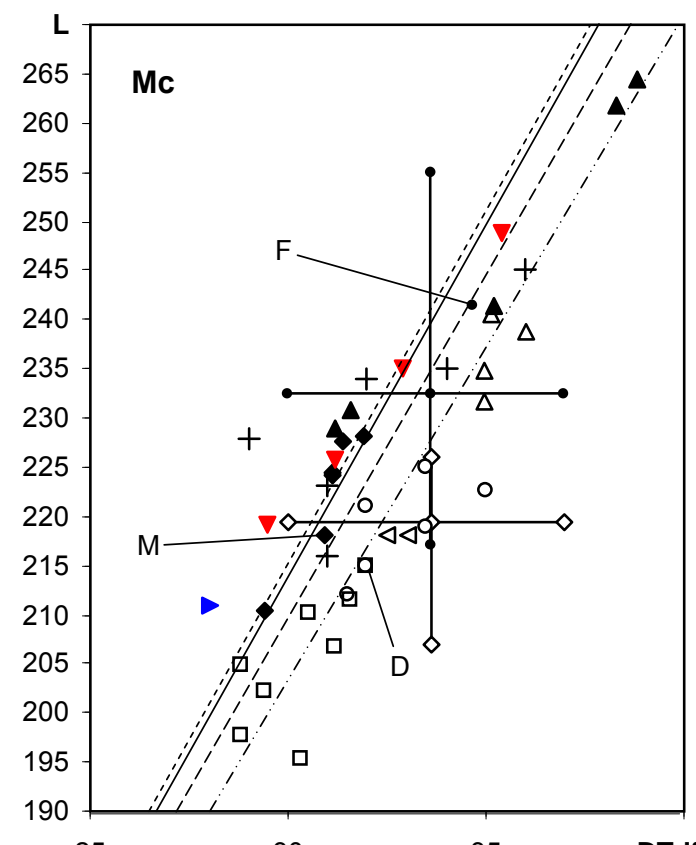

- D. rhenana rhenana Tegelen \& Montopoli (M)

- D. rhenana philisi Senèze \& Fonelas $(F)$

\ D. vallonnetensis Untermassfeld

$\nabla$ Dama Atapuerca TD8

- Dama Venta Micena

$\triangle \quad$ Dama robertorum?

$\triangleleft \quad$ Dama Capena

$\diamond \quad$ Dama valliensis St. Vallier

口 Dama nestii nestii U Valdarno \& Dmanisis (D)

- D. nestii farnetensis Selvella

+ Dama clactoniana Clacton \& Swanscombe

- . - D. rhenana rhenana $L=7.1747$ DTdf

D. vallonnetensis $\mathrm{L}=7.1356 \mathrm{DTdf}$

- - - . D. nestii nestii $\mathrm{L}=6,7686 \mathrm{DTdf}$

----- Dama clactoniana $\mathrm{L}=6.9906$ DTdf

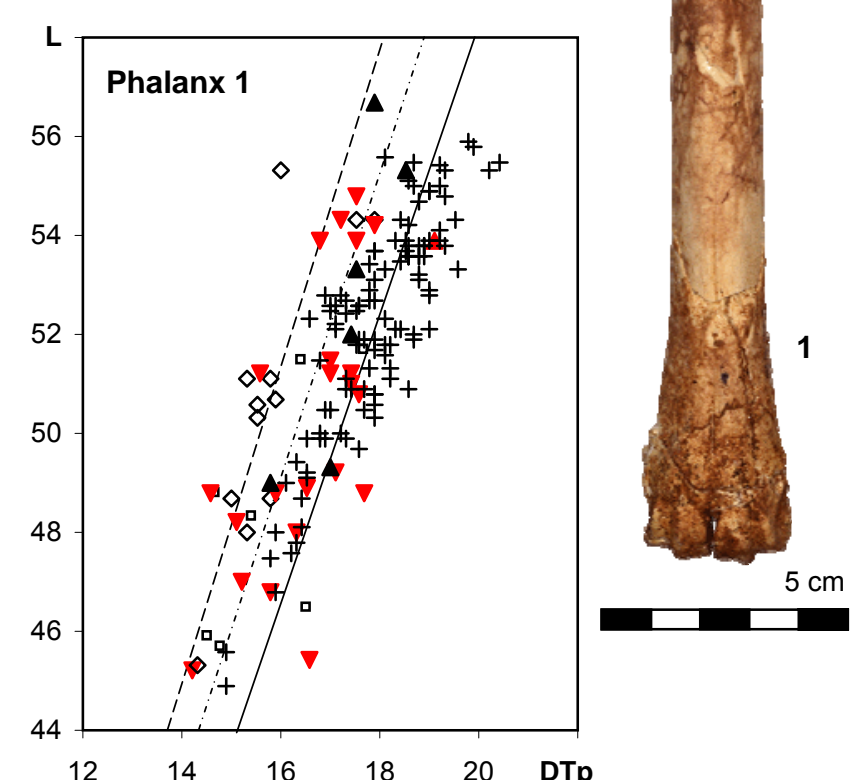

+ Dama clactoniana Clacton \& Swanscombe

- D. dama geiselana Neumark Nord

- - Dama clactoniana $L=7.1356$ DTdf

- . D D. dama geiselana $L=6.7806 \mathrm{Tdf}$



$2 a$

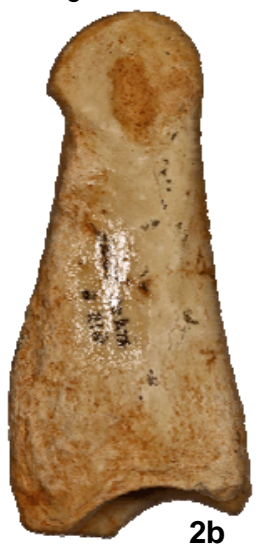

2b

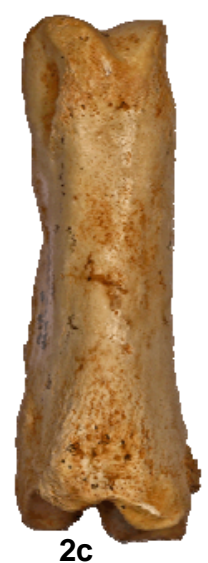

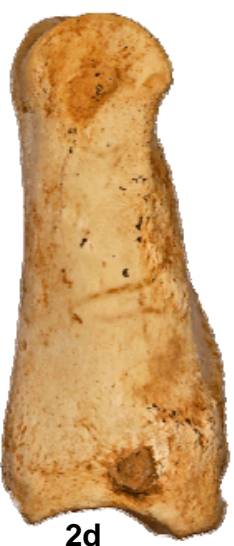

2d $\diamond$ Dama rhenana Tegelen

- Dama nestii Upper Valdarno

$\checkmark$ Dama Atapuerca TD8

+ D. d. geiselana Neumark Nord

- D. vallonnetensis Untermassfeld

---- Dama rhenana L = 3.2024 DTp

-..... Dama nestii L $=2.9063 \mathrm{DTp}$

D. $d$ geiselana $\mathrm{L}=3.0685 \mathrm{DTp}$
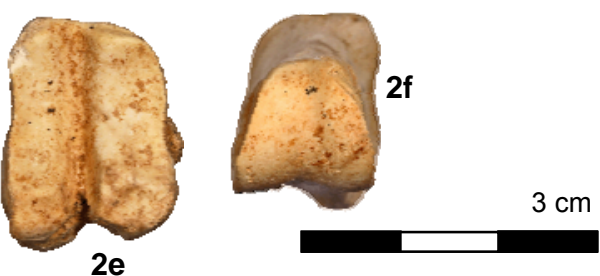

Figure 16

The metacarpal and first phalanx of Dama vallonnetensis from Atapuerca TD8: 1) Ata02, TD8b, G-8, 55+39 - left metacarpal, anterior view. 2) Ata03, TD8b, G-15, 6 - first phalanx, right of the axis of the foot, a) plantar, b) axial, c) dorsal, d) abaxial, e) proximal, and f) distal views.

Bivariate diagram comparing the distal width (DTdf) and length (L) of the metacarpals of Dama vallonnetensis from Atapuerca TD8 to those of Dama rhenana rhenana from Tegelen (NMMaa, NBC) and Montopoli (IGF); Dama rhenana philisi from Senèze (Heintz, 1970) and Fonelas (Garrido, 2008); Dama vallonnetensis from Untermassfeld (Kahlke, 1997);

Dama robertorum? from Isernia la Pineta and Valdemino (Breda et al., 2015) and from Overstrand and Trimingham (Azzaroli, 1953); Dama from Venta Micena (Menéndez, 1987); Dama from Capena (Petronio, 1979); Dama valliensis from Saint Vallier (Heintz, 1970); Dama nestii nestii from the Upper Valdarno (IGF) and Dmanisi (GSM); Dama nestii farnetensis from Selvella (Azzaroli, 1992); and Dama clactoniana from Clacton, Swanscombe and Jaywick (all Leonardi and Petronio, 1976). As an indication for the expected variability of a population, a diagram is given with the large sample of Dama dama geiselana from Neumark Nord (Halle).

Bivariate diagram comparing the proximal width (DTp) and length (L) of the first phalanges of Dama rhenana from Tegelen

(NBC, NMMaa); Dama nestii from the Upper Valdarno (IGF); Dama vallonnetensis from Untermassfeld (Kahlke, 1997); Dama dama geiselana from Neumark Nord (Halle). 
further medially at its distal part than at its proximal part and a not very pronounced bulge at the medio-distal end of this facet (feature 4 and 5 of Lister, 1996), as in Dama and unlike in Cervus. This is so in, for instance, Ata02, TD8b, G-17, 103, but occasionally this is the other way around in a specimen (Ata06, TD8b, G-3, 5), which has the same size as the other specimens and is far too small for Cervus (Table 20).

The scapula tends to have the tuberosity hook-shaped as in Dama, but this is variable.

Other teeth and bones are indicated in the tables, but are not described here in detail.

\subsubsection{Remarks on taxonomy and evolution}

The European Pleistocene deer with a size between the roe and red deer include the living fallow deer and many other species, which share many morphological features besides the modest size. All agree that the name Dama applies to the species with palmate antlers (Dama dama, D. mesopotamica and D. clactoniana), while the nonpalmate species are under discussion and the different authors include them in different genera, such as: Dama (e.g. Azzaroli, 1948, 1953; Van der Made, 1999a, 2001, etc.; Pfeiffer, 1999; Croitor, 2006; Breda \& Lister, 2013), the living genera Axis, Rusa or Cervus (e.g. Spaan, 1992; De Lumley et al., 1998; H.D. Kahlke, 1997, 2001a; Croitor, 2006 ), or in a genus based on a fossil species, like Metacervoceros, Pseudodama, and Euraxis (Azzaroli, 1992; Di Stefano, 1995 a; Di Stefano \& Petronio, 1998, 2002; Croitor, 2006).

Lister (1996) described many morphological differences between Dama and Cervus. The non-palmate Dama-like deer tend to have the morphologies that are typical of Dama and differ in these from Cervus, Rusa and Axis. A cladistic analysis groups several of these species with Dama (Pfeiffer, 1999). These species have antlers with three or four points, but the recently described species Dama robertorum includes an apparently adult antler from Soleilhac (Figure 13/6) with only two points and a skull cap with a pair of antlers from from Pakefield, which are not totally complete, but which both widen towards, what could have been the split between two tines (Figure 13/5). If this were indeed the case, it would have had three tines. The fossils of a small deer from Atapuerca TE9 were assigned to D. vallonnetensis and include a complete antler with three points, that is very similar to the material from Pakefield.

The new data mentioned above, suggest the existence of two divergent evolutionary trends within the Dama-like deer: one with increasing antler complexity, leading to the palmate Dama, and another one, which went un-noticed until recently, with decreasing antler complexity, leading to the two pointed Dama robertorum.

Figure 16 includes a bivariate diagram that shows that the Dama-like deer are divided in two groups according to the robusticity of their metacarpals. Species with gracile metapodials (length around 7 times distal width; L $\approx 7$ DTdf) include Dama rhenana rhenana and Dama rhenana philisi with three points, and Dama vallonnetensis, of which the number of points is not known from the type material. Species with robust metapodials ( $\mathrm{L} \approx 6.5$ DTdf) include the three pointed "Cervus philisi" valliensis Heintz, 1970 and the four pointed Dama nestii. Metapodials recently assigned to Dama roberti (Breda et al., 2015) are robust and others previously described by Azzaroli (1953) are very similar in size and proportions (Figure 16). The deer from Capena (Petronio, 1979) has an antler with three points and robust metapodials (Figure 16).

These differences in robusticity of the metapodials seem small, but there are similar and consistent differences between the living species of deer, which probably reflect different ecologies. Though it is not the intention here to discuss the ecology of these species, it should be noted that functional morphology suggests that longer metapodials mean a longer stride length and probably a greater maximum speed, beneficial in open landscapes, while shorter metapodials might may allow faster acceleration, favourable when cover is near.

The taxa in the range chart in Figure 13 can be characterized using a limited number of features: - Dama valliensis has robust metapodials (Figure 16), three pointed antlers and probably a bifurcation of the main beam and brow tine that is situated far from the burr. Heintz (1970) named the taxon as a subspecies of "Cervus" philisi, but it differs clearly from that species in having more robust metapodials.

- Dama robertorum has robust metapodials (Figure 16) and may have reduced the points in the antler from three to two (Figures 13/5, 13/6); it is a larger species than the previous one (Figure 16). The deer from Capena seems to belong to either $D$. robertorum or $D$. valliernsis.

- Dama nestii nestii has robust metapodials (Figure 16), four pointed antlers (Figure 13/2) and a bifurcation of the main beam and brow tine that is far above the burr (Figure 13).

- Dama nestii eurygonos has a wider angle between the brow tine and main beam (Azzaroli, 1992) and is a little larger than $D$. n. nestii, if the metapodials from Selvella indeed belong to this subspecies (Figure 16), while dentally, there does not seem to be size difference (Figure 15).

- Dama rhenana has gracile metapodials (Figure 16), three pointed antlers (Figure 13/3) and a very high first bifurcation of the antler (Figure 13/diagram). It is a small species (Figure 15/diagram). Spaan (1992) considered “Cervus" philisi synonymous with "Cervus” rhenanus. However, they are not exactly identical: what is here considered the subspecies D. r. philisi is a little larger than D. r. rhenana (Figure 16).

- Dama vallonnetensis has gracile metapodials (Figure 16), a first bifurcation that is much lower than in $D$. 
rhenana (Figure 13).

- The later Dama had palmate antlers (Figure 13/7) and low bifurcations (Figure 13/diagram).

These different species have to belong to different lineages, but the lowering of the bifurcation seems to be a general trend, occurring in all of them (Figure 13). If there are parallel lineages, it would be expected that there are differences in size between the contemporary species. Nevertheless, the size of the $\mathrm{M}_{3}$ of the different samples do not suggest species of different size at the same time, but rather a large scale general size fluctuation over 2.5 Ma for all species.

The material from the lower part of the Atapuerca Gran Dolina sequence has previously been assigned to Dama cf. clactoniana, Dama nestii? vallonnetensis, Dama "nestii" vallonnetensis and Dama vallonnetensis (Soto, 1987; Azanza \& Sánchez, 1990; Van der Made, 1998a, 1999a, 2013; Rodríguez et al., 2011). Now there are large collections from the different levels of Gran Dolina, which permit to discuss the affinities of the deer of each level individually. The deer from TD8 shares gracile metapodials with Dama rhenana, D. vallonnetensis and the earliest palmate Dama, D. clactoniana (Figure 16). The bifurcation between brow tine and main beam is low, as in D. vallonnetensis and unlike in D. rhenana, where it is high (Figure 13). The distal part of the antler is not known from TD8, so the number of tines or the possible presence of a palmation is not known in this level. The size, as indicated by the $\mathrm{M}_{3}$ size, is in the range of Dama vallonnetensis and is smaller than in $D$. clactoniana from Swanscombe or Bilzingsleben (Figure 15). These features allow to attribute the material from TD8 to Dama vallonnetensis.

Above the species Dama roberti was mentioned. Pomel (1853, p. 103) named a Cervus roberti and gave in the synonymy “Cervus dama polignacus F. Robert”. Azzaroli (1953, p. 83) indicated that "the name Cervus Dama polignacus was given by Robert (1829) to two incomplete skeletons from Solilhac: one of them is identical with his Cervus solilhacus (now Megaceros solilhacus) from the same locality. The second is a small red deer with abnormal characters; Pomel (1853) named it Cervus roberti.” Breda \& Lister (2013, p. 157) wrote "Robert (1829) described the small cervid remains from Soleilhac, here the paratype of D. roberti, immediately after his description of a much larger deer species from the same area that he named Cervus Dama polignacus”. The combination of all this information suggests, that the holotype of Cervus roberti Pomel, 1853 is the paratype of Dama roberti Breda \& Lister, 2013. If this indeed is the case, the two species could be synonymous and homonymous at the same time. However, the situation is more complicated. Since Breda \& Lister (2013) named the species in honour of two men, Robert Mutch and Félix Robert, this is an inadvertent error and should be corrected (ICZN, 1999, article 32.5.1) to Dama robertorum Breda \& Lister, 2013. With this correction, there is no homonymy anymore. There is still another complication. The holotype of Dama robertorum is from Pakefield and the main beams of the antlers become distally markedly flattened, suggesting a split into two tines, so that the antler has three points. The paratype from Solilhac has two points. If these differences would reflect an evolutionary reduction of the number of tines, the two names would apply to the two different forms.

\title{
3.9. Bison
}

\author{
Family Bovidae \\ Genus Bison \\ Bison voigtstedtensis Fischer, 1965
}

\subsubsection{Material}

All material studied here is listed in Tables 28-30 (supplementary data). A taphonomic study assigned 60 fossils to a bovine, representing a minimum of 4 individuals (Rosell, et al., 2010).

\subsubsection{Description and comparison}

The upper molars (Figures 17/1-2) have marked styles on the buccal side and interlobular columns on the lingual side. They have high crowns. This morphology is typical of the Bovini.

The lower molars (Figure 17/3) have marked stylids on the lingual side and interlobular columns on the buccal side. The third lobe of the $\mathrm{M}_{3}$ has no fossid, but is a single crest formed by the pentatonic and its pre- and endocristid. Again, these morphologies are typical of the Bovini. The size of the $\mathrm{M}_{3}$ from TD8 is in the lower ranges of Bison schoetensacki from its type locality Mauer, B. schoetensacki lagenocornis from its type locality Süssenborn and B. menneri from its type locality Untermassfeld (Figure 14). It is slightly bigger than the few specimens of $B$. degiulii from its type locality Pirro Nord and in the ranges of $B$. voigtstedtensis from its type locality Voigtstedt and of the material from Süssenborn, which might belong to the latter species.

The upper and lower premolars, deciduous molars and incisors have also bovine morphologies.

The first phalanx (Figure 11/2) has a very low and wide facet for the abaxial sesamoid (feature a), a marked fossa in the middle below the proximal articulation (feature b), no indication of an proximo-axial 




Figure 17

Bison voigtstedtensis from Atapuerca TD8: 1) Ata02, TD8b, G7, 90 - right M3: a) buccal, b) occlusal view; 2) Ata02, TD8b, G8, 21 - right M2: a) buccal, b) occlusal view; 3) Ata02, TD8b, G12, 26 - right M3: a) lingual, b) occlusal, c) buccal view.

The temporal distribution of the European bisons. Conventions as in Figure 5.

Bivariate diagram of the width of the anterior (DTa) and posterior lobe (DTp) of the M3, comparing Bison voigtstedtensis from Atapuerca TD8 with: B. menneri from Untermassfeld (IQW); $B$. voigtstedtensis from Voigtstedt (IQW); B. voigtstedtensis? from Süssenborn (IQW), B. degiulii from Pirro Nord (IGF); B. schoetensacki lagenocornis from Süssenborn (IQW9; B. schoetensacki from Mauer (SMNK). 
tuberosity on the dorsal side (feature d of Heintz, 1970). Features a, b, and d are as in Bovidae, while Heintz' description of feature $\mathrm{c}$ is less clear. In addition, it has a distal articular surface with a longitudinal grove that is U-shaped, while in the giant deer it is more open $\mathrm{V}$-shaped. The proximal articular surface is wide and low and its dorso-abaxial corner sticks out making the contour of the facet square. The facets for the sesamoids are low. Though the phalanges are small for a bison, these are all morphological differences with the phalanges of the giant deer and similarities to Bison. There is a well developed ridge on the axial edge of the plantar surface. The specimens from TD8 are more robust than those of the giant deer and are similar to those of B. schoetensacki, but are not more robust than the most robust B. menneri. For a bison, they are small, as is the case in $B$. giulii. A comparison with Leptobos was made, but not included in Figure 11 for keeping the figure simple. The phalanges of TD8 are as long as those of Leptobos, but wider and more robust.

The second phalanx (Figure 9/2) is stout and has a wide and low proximal articular surface. The plantar edge of this surface is situated much more proximally, than the "post-articular surface" below it, especially at the axial side. The ridge in the middle of the articular surface forms a little protruding point at the plantar edge of this surface. These morphologies are common in Bovini, but not in deer. The phalanges from TD8 are very small compared to those of Bison menneri, B. schoetensacki, B. priscus and Bos primigenius (Figure 9). No comparisons with the second phalanx of the very small species Bison degiulii could be made, nor with Bison voigtstedtensis. The phalanges are robust compared to those of Leptobos and one of them is distinctly more robust. In a previous study (Van der Made, 1998 a, fig. 8), a bison phalanx from TD8 and one from Voigtstedt taken as typical for B. voigtstedtensis were compared to data on Bison schoetensacki, B. priscus and Bos primigenius taken from Sala (1987) and were found to be much narrower. This would imply, that $B$. voigtstedtensis does not only have more slender metapodials than $B$. schoetensacki, but also more slender second phalanges, making identification of such bones very easy. However, Sala's measurements for the three species have nearly all DAPd $<$ DTd and differ from the measurements one of us (JvdM) took on these species. The most plausible explanation is that Sala (1987) measured the specimens in a different way. Also the more extensive comparisons suggest that the phalanx from Voigtstedt seems more likely to be Megaceroides. Here the measurements are taken as indicated by Van der Made (1996, fig. 20) and the four specimens from TD8 are not narrower than those of Bison schoetensacki and Bos primigenius (Figure 9).

The third phalanx differs from the phalanx of the large Cervidae, which are also present in TD8, in having two well developed foramina on the proximal part of the dorsal side (Figure 9/4), an axial and an abaxial one, and a small one on the proximo-plantar part of the axial side. The abaxial dorsal foramen does not occur in the Cervidae, and usually (but not always) the axial proximo-plantar foramen is lacking in the Bovidae (Heintz, 1970).

There are several other bones, which have relatively small sizes, but their morphologies suggest they belong to the bison, rather than to the giant deer. The sesamoids are low and rounded, and the carpals low and wide, like in the Bovinae and unlike in Cervidae. The humerus as a distal articulation, that is low and wide.

\subsubsection{Remarks on taxonomy and evolution}

Bisons appeared in western Europe during the later part of the Early Pleistocene, probably close to 1.2 Ma (Van der Made, 2013), replacing the more primitive bovine Leptobos. Around the middle of the Middle Pleistocene, the aurochs Bos primigenius appeared. Commonly recognized species of bison in western Europe include Bison voigtstedtensis, Bison priscus, the living species Bison bonasus, as well as Bison degiulii and Bison menneri (Flerov, 1975; Masini, 1989; Crégut-Bonnoure \& Guérin, 1996; Sher, 1997). A small bovine from Atapuerca TG (Van der Made, 1999c) and also TD10 is now believed to be a form close to Bison priscus. The temporal distribution of these species is indicated in Figure 14.

The different species of Bison differ in the morphology of the skull, which is relatively narrow in Bison menneri and B. voigtstedtensis (R.D. Kahlke, 2006; Fischer, 1965; Soto, 1987), and wide in B. degiulii, B. schoetensacki and B. priscus and B. bonasus (De Giuli et al., 1987; Sala, 1987; Flerov, 1975). They differ also in orientation, shape and size of the horn cores. Sher $(1992,1997)$ documented major differences in size and robusticity of the metacarpals: Bison menneri has gracile metacarpals, B. schoetensacki and B. giulii have more robust, the ones of $B$. giulii being clearly smaller, and B. priscus has still more robust metacarpals.

Sher (1997) noted the presence of different types of metacarpals in Süssenborn. In a much increased data set, the B. schoetensacki clusters are much wider than Sher's and include hist "Bison priscus”, while it becomes apparent that Sher's Roterberg sample is more likely to be Bison priscus. Most of the Süssenborn metacarpals cluster with $B$. schoetensacki, while one clusters indeed with $B$. menneri. It has a great length, but it is slender and has a small width, suggesting it belonged to a small individual or species and this is most probably Bison voigtstedtensis, which shares also skull and horn core morphology with $B$. menneri. The teeth of $B$. voigtstedtensis are also on average smaller than those of $B$. menneri and B. schoetensacki (Figure 17). There are a number of teeth from Süssenborn, which are too small for Bison schoetensacki, the dominant species in this 
locality, and which more likely belong also to B. voigtstedtensis.

Remains from the lower part of the Gran Dolina sequence have previously been tentatively assigned to Bison voigtstedtensis (Soto, 1987; Van der Made, 1998a, 1999a, etc.). This was largely based on a skull from TD4 or a lower level and a metapodial from TD4, but now there is more material from TD8.

The phalanges from TD8 have a series of morphologies typical of Bovidae or Bovini and are more robust than those of Leptobos, and smaller than those of Bos primigenius (Figures 9 \& 11). Compared to the different species of Bison, they are smaller than those of B. menneri and B. schoetensacki and smaller and more gracile than those of $B$. priscus. In addition, the first phalanges are close to those of $B$. degiulii. No second phalanges of that species could be studied and also no phalanges, that were reliably assigned to Bison voigtstedtensis, were included in Figures $9 \& 11$. Since the teeth of $B$. voigtstedtensis are smaller than those of $B$. menneri (Figure 14), the same might be expected for the phalanges. The material from TD8 seems thus to be most similar to $B$. voigtstedtensis or $B$. giulii. The latter, is a much older species and may have evolved into $B$. schoetensacki long before the fossil association of TD8 was formed. These data support the earlier tentative assignation to Bison voigtstedtensis. Bison voigtstedtensis is a relatively rare species and much of its skeleton is not well known, but the continuing excavations in the lower part of Gran Dolina may solve this.

\section{THE CONTEXT: FAUNAL CHANGES AROUND THE E-M PLEISTOCENE TRANSITION}

The lower part of the Gran Dolina sequence, including TD8, is situated chronologically in the middle of the climatic and faunal changes, which occurred from the end of the Early to the beginning of the Middle Pleistocene. This can be seen in Figure 18, which includes around 50 localities, covering ages from around 1.2 Ma to $0.5 \mathrm{Ma}$, and their large mammal species or genera. The date of about 1.2 Ma is chosen, because that is when the faunal change (which "grosso modo" is associated to the E-M Pleistocene transition) started, and the date of $0.5 \mathrm{Ma}$ is chosen because it is sufficiently after that transition.

The localities in figure 18 were selected on the basis of their associations being varied and representative of a particular time, the recording of first or last appearances, and the availability of independent means of dating. Table 31 (supplementary information) gives the references to the published faunal lists of the localities and the different dates of the localities, dating techniques and references. Even though there is on average about one locality per $15 \mathrm{ky}$, the faunal associations of some times or climatic cycles are not well represented and more localities are needed. However, many localities, even well-known ones, with a varied faunal list cannot be precisely assigned to faunal associations of a particular time, because they lack the important taxa.

The large mammals included in Figure 18 are about 70 species or genera of Proboscidea, Perissodactyla, Artiodactyla, Carnivora and Primates, but do not include Homo, nor Mustelidae, which generally are small. Though literature is cited for the faunal lists (Table 31), classifications may have been changed on the basis of specialised literature (dedicated to a taxon and not to a fossil locality), the discussions in the previous section, or on own observations. If there is an established, or likely, ancestor-descendant relationship between species, the thick lines indicating their temporal range are connected. Probably not all cases are indicated. The taxa are ordered by appearance and disappearance, save for the cases of evolution from a previously present species.

At the first sight, Figure 18 shows gradual change, but in detail, there appear to be many discrete events. At the right side, the appearance of 36 taxa can be seen, concentrated in approximately 10 events. At the left side the disappearances are not that prominent. In part this is an impression due to the ordering of the taxa, which favours the pattern of appearance, but it is also real. There are about 22 disappearances, so the diversity increased. Due to the cyclic appearance of the glacial fauna, the disappearances are not always clear: for instance, Praeovibos priscus re-appeared, Soergelia elisabethae probably did not and Ovibos pallantis reappeared much later (in a time not covered by the figure). The different events are discussed below. It should be understood, that these events are described on the basis of the data in Figure 18, but that new dates for the localities, new fossils, systematic revisions or the inclusion of new localities may change the grouping of individual dispersals in events and the dates of these events.

\subsection{The dispersals of hippopotamus and two species of large deer.}

The first faunal event in Figure 18 is the arrival of Hippopotamus tiberinus (=? H. georgicus =? H. gorgops; section 3.4.), a large deer indicated as Megaloceros sp. L, a large deer called Eucladoceros sp. T and possibly one of the Dama-like deer. Megaloceros sp. L from Libakos has been discussed by Van der Made \& Tong (2008). Eucladoceros sp. T includes material from Trlica (Van der Made \& Dimitrijević, in press) and probably material from Kapetianos, described originally as Eucladoceros aff. boulei (Steensma, 1988), which shares the 





morphology of the antler base.

These taxa appear first in three Greek localities, of which Libakos has a varied faunal list and the other two poor faunal lists. Two of the localities still have Leptobos. The tree are geographically close and probably also chronologically, though there might be minor age differences. Libakos was “dated” biochronologically to 1.2 Ma (Steensma, 1988).

Hippopotamus gorgops, present in the North of Africa dispersed northward, reaching Israel, where it is known from Ubeidiya (about 1.4 Ma), and apparently reaching Greece a little later. The Eucladoceros probably came from East Asia and the Megaloceros from Asia or eastern Europe. None of these species are cold or arid adapted and if their arrival is related to climatic or environmental change, this may have been during the very warm stage 37 , or alternatively the warm stages $47 / 49$, close to $1.4 \mathrm{Ma}$.

\subsection{Events possibly related to stage 36: the dispersal of the first bisons}

A second event seems to be the arrival of Bison degiulii, Soergelia minor, "Capra” alba, Praeovibos and maybe Bison menneri.

The bisons have been discussed in section 3.9. Bison degiulii appears first in Pirro Nord, Sainzelles, Capena and Redicicoli (De Giuli et al., 1987; Masini, 1989). They replaced Leptobos, but may have co-existed for a short time. Material from Venta Micena was initially assigned to Bison sp. (Moyà-Solà, 1987), later to Bubalus sp. (Martínez-Navarro, 1992) and more recently out of 938 specimens one was assigned to Hemibos sp. aff. H. gracilis and one to Bison sp. (Martínez Navarro, et al., 2011). Each of these two identifications is based on about one promille of the available material, and is therefore preliminar. The first specimen, assigned to Hemibos, is a skull fragment, which has similarities to Leptobos brevicornis, defined on the basis of material from Gongwangling and present also in Yunxian (Hu \& Qi, 1978; Echassoux et al., 2008), rather than to Hemibos gracilis, defined in the much older locality Longdan (Qiu et al, 2004). Both are bovines with backward directed horn cores. In any case, it seems that Leptobos survived for a short time after the arrival of bisons. Material from Barranco León 5 and Fuente Nueva 3 (Martínez-Navarro et al., 2010) either represents primitive bison or Leptobos. A large bison identical to B. menneri appears first in Atapuerca TE9.

Soergelia and Praeovibos are present in Venta Micena and Pirro Nord (Moyà Solà, 1987; De Giuli et al., 1987). Soergelia is also cited from Monte Argentario, which is possibly close in age to Pirro Nord (Siori et al., 2014). This marks the first occurrence of Soergelia in western Europe, but its origin is known: there is a much older record from Dmanisi (Vekua, 1995), with a morphology that is similar to the one from Venta Micena. Citations of possible still older Praeovibos are from Casa Frata (De Giuli \& Masini, 1983; Sher, 1992) and Fonelas (Garrido, 2008b), with ages in the range 2.1 to 1.7 Ma. However, these do not include horn cores (the most significant element). A metapodial from Casa Frata, that has been cited as Praeovibos, is a little more robust than the few ones known of Megalovis, the more common ovibovine of this time, but still could fit this taxon.

"Capra” alba was first described from Venta Micena, but is also present in Quibas and Huéscar and seems to be present in Barranco Léon 5 (Moyà Solà, 1987; Montoya et al., 1999, 2001; Van der Made et al., 2008; Martínez-Navarro et al., 2010). It is different from Capra baetica, described from Fonelas (Arribas \& Garrido, 2008), situated below the Olduvai.

Most of the aforementioned localities have similar faunas, including Venta Micena, Barranco León, Fuente Nueva 3, Quibas, and Sainzelles, but several of these have Equus altidens, while Pirro Nord has a more primitive Equus (see section 3.1.) and therefore is probably a little older. Pirro Nord was placed on biochronology between 1.2 and 1.3 Ma (Sardella et al., 1998), but later, after lithic industry was found, older ages were mentioned, based on rodents and correlations to Venta Micena (Arzarello et al., 2007). Fuente Nueva 3 has been dated close to 1.19 $\pm 0.21 \mathrm{Ma}$ (Duval et al., 2012). Venta Micena was dated by amino acid racemisation to $1095 \pm 55$ ka (Ortíz et al., 2000). Duval et al. (2012) analysed five samples for combined U-series/ESR dating: two very young samples were discarded for technical and the remaining three gave an average of 1.37 Ma (Duval et al., 2011). However, a value of 1.79 Ma is much older than the other two dates used; if it would be considered as an outlier, the remaining values would give as an average 1.105 Ma, close to the date by Ortiz et al. (2000).

Soergelia and Praeovibos are generally considered to be cold adapted taxa, and, at least in the Middle Pleistocene, they tend to be present in glacial faunas (sections 4.5. and 4.8.). However, in Venta Micena, the more primitive species of these genera occur along with Hippopotamus, usually seen as an interglacial taxon. It is possible, that in the Early Pleistocene, these Ovibovini were not yet so much adapted to cold as well as to open environments. In any case, it seems likely, that these taxa were adapted to open or dry landscapes. The dispersal of Ovibovini, "Capra” alba and bisons, adapted to open or arid environments into western Europe may have occurred during a cold period, when open environments prevailed; once in open and dry landscapes in the SW of Europe, they could have survived into the following warm periods. Stage 36 is colder and longer than previous 
isotope stages and marks the beginning of the shift towards the $100 \mathrm{ka}$ climatic cycles, culminating in the well known Middle and Late Pleistocene glaciations. During these well studied glaciations, the northern limit of distribution of trees moved southward and, as result, the taiga disappeared and the tundra and steppe fused into, what is called, the "Mammoth steppe" (e.g. Guthrie, 1990). The open landscape could have permitted dispersals into western Europe of species adapted to open landscapes, which then could reach Spain, which probably always had a more open landscape than Europe north of the Pyrenees. This could have happened during stage 36, allowing bisons to reach western Europe. The restauration of the Taiga during the following warm period may have been a gradual process. This is well studied for the later interglacials: temperatures rise, pollen diagrams show predominance of herbs (open landscapes), subsequently one tree type after the other arrives and becomes abundant. It has been proposed, that this process, permitted humans to reach western Europe at the end of stage 36 (Van der Made, 2011a, 2013).

\subsection{Events before or around the beginning of the Jaramillo}

Various taxa appeared and disappeared shortly before or around the beginning of the Jaramillo.

Bison schoetensacki is very similar to B. degiulii, but is a little larger (section 3.9.) and its appearance is probably by evolution from that species.

Stephanorhinus hundsheimensis is cited from several pre-Jaramillo localities. The taxonomic problems regarding this taxon have been discussed above (section 3.2.) and in some cases it seems very likely, that the rhinoceros present in these localities is the small form, assigned here to $S$. etruscus. If this is the case, $S$. hundsheimensis may have appeared within the Jaramillo.

Eucladoceros giulii is present in Untermassfeld (H.D. Kahlke, 1997), but also in Vallonnet (section 3.6.). The fossils of large deer from TE9 fit E. giulii. This is a large deer with slender metapodials and antlers with tines originating at the front of the main beam, and with little indication of these tines being bifurcated, save for the brow tine (Figure 10). The earliest Eucladoceros had antlers with many simple tines, but by the Olduvai, these tines bifurcated, resulting in very complex antlers. Still later, the small E. tetraceros appeared, which had again simple, non-bifurcating tines. A large deer from Ceyssaguet with antlers with tines that do not or nearly not bifurcate was assigned to E. ctenoides (Croitor \& Bonifay, 2001). For various reasons, it seems more likely, that this material belongs E. tetraceros or E. giulii. The appearance of the latter could be related to the demise of Eucladoceros sp. T.

Hemitragus bonali is first recorded in Vallonnet (Moullé, 1998; Moullé et al., 2006).

Untermassfeld and Vallonnet have Sus sp., which resembles Sus strozzii in the section of its canine, but which differ in other features. The same form could be present in Atapuerca TE9.

The name Ursus etruscus used to be applied to late Early Pleistocene bears, but now Ursus rodei has been defined in Untermassfeld (Musil, 2001) and Ursus dolinensis in Atapuerca TDW4 (García \& Arsuaga, 2001). The cladogram by the latter authors is compatible with a model in which $U$. etruscus gave rise to the brown bear $U$. arctos on the one hand and the cave bear lineage with $U$. savini, U. deningeri and U. spelaeus on the other. It is not clear in how far this affects the attributions of bear material slightly older than the Jaramillo, that were traditionally assigned to U. etruscus.

The equid Equus altidens became rare or absent and a larger, but otherwise similar horse appeared, to which the names Equus wuesti, E. nalaikhensis and E. hipparionoides have been applied, while later E. altidens reappeared. It is not clear whether this is a fluctuation in size, or whether these are different lineages (see section 3.1.; Figure 4). Equus wuesti is present in Untermassfeld and E. hipparionoides in Akhalkalaki (Musil, 2001; Vekua, 1986).

The oldest locality in which these changes have been recorded may be Ceyssaguet, if E. giulii is indeed present there. This locality is in a maar, and the underlaying rock has been dated to $1.3 \mathrm{Ma}$, and the fossils have been estimated to date to 1.2 Ma (Kaiser \& Croitor, 2004). The next locality that records these changes is Atapuerca TE9, dated to 1220 +/- $140 \mathrm{ka}$, and the underlaying TE7, dated to 1130 +/- $180 \mathrm{ka}$ (Carbonell et al., 2008), resulting in a likely age of a little less than 1.2 Ma. Given the differences in fauna, these localities are probably younger than Fuente Nueva 3, which has been dated to 1.19 $\pm 0.21 \mathrm{Ma}$ (Duval et al., 2012). The next oldest localities are Jaramillo in age. Since the taxa which dispersed are mostly probably adapted to warm or more or less closed environments, these events may have occurred during stages 33 or 31.

\subsection{Events around the end of the Jaramillo}

Crocuta crocuta, is first recorded in Atapuerca TD4-8 and Akhalkalaki and somewhat later in Casal Selce near Rome and has a previous record in Ubeidiya and in Africa (García \& Arsuaga, 2001; Sardella \& Petrucci, 2012).

Eucladoceros aff. giulii is first recorded in Atapuerca TD4-6, Akhalkalaki and Apollonia 1 and replaced E. giulii, present in Untermassfeld and Vallonnet (section 3.6.).

Sus scrofa is first recorded in Atapuerca TD6 (Van der Made, 1999a) and a bone from TD5 may belong 
to the same species (section 3.3.). It replaced a species with verrucose canines, present in Untermassfeld and Vallonnet.

Unequivocal antlers of Cervus elaphus have been recovered from Atapuerca TDW4, while dental remains attest its presence in Dorn Dürkheim. The species has been cited from Mosbach 1, but it is not clear on which material this is based. Further to the east, it is described from Trlica in Montenegro (section 3.5.).

The evolution of Megaceroides with large brow tines and branching antlers to M. solilhacus with reduced brow tines and palmate antlers seems to have occurred around the end of the Jaramillo (section 3.7.).

The latest record of "Capra” alba and possibly of primitive Soergelia are in Huéscar and this age. However, the locality has recently been dated (Demuro et al. in press),but that very young date is incompatible with the microfauna. There might be a hiatus in the presence of Soergelia, starting at this time, but this is problematic, since most samples of this bovid (including Huéscar and Vallonnet) do not have enough systematically relevant elements.

Crocuta, Sus scrofa, and Eucladoceros aff. giulii are first recorded in Atapuerca TD4-6 and this is also the case for the first certain Cervus elaphus in western Europe. These levels are situated below the Santa Rosa event and above the Jaramillo (Parés et al., 2013), bracketing these dispersals between 0.99 and 0.936 Ma. Crocuta crocuta came from SW Asia and favoured open landscapes, while the other species are temperate and came from mid latitudes in Asia or eastern Europe. At least the latter events occurred probably during a temperate stage, probably 27 or 25.

\subsection{The appearance of the giant elk}

In mid-latitude Europe, the elk Alces carnutorum was replaced by the giant elk Alces latifrons. The former is last recorded from a unit below the main site at Voigtstedt and at St. Prest, and the latter is first recorded from Happisburgh and Dorn Dürkheim. For discussions on this event see Breda \& Marchetti (2005), Ravazzi et al. (2005), as well as Parfitt et al. (2010). Here the entry of A. latifrons is taken at the moment when very large forms replace much smaller ones (Van der Made et al., 2014).

Praeovibos re-appeared after period of absence and is known from Apollonia, where the material is rather poor. In Atapuerca TD7, below the Brunhes-Matuyama boundary, there is good material suggesting that this is Praeovibos priscus, the species known from the Middle Pleistocene.

Soergelia has in Europe a total temporal range of just some 0.6 Ma, but there are six species names for them or very similar forms: S. minor, S. intermedia, Megalovis balcanicus, Ammotragus europaeus, S. brigittae, S. elisabethae (Schaub, 1951; Moyà Solà, 1987; Kostopoulos, 1997, Moulé et al., 2004; Crégut-Bonnoure \& Dimitrijević, 2006). Probably there are more names than real species.

The geologically oldest and second named species, is Soergelia minor from Venta Micena, which has slender horn cores, that are oriented more upwards and which curve forwards in a pronounced way. Megalovis balcanicus from Trlica has similar horn cores, save for that these are very flattened. Its horn cores are very different from those of the typical Megalovis. Soergelia intermedia is defined on poorer material from Trlica. Moullé et al. (2004) named the species Ammotragus europaeus on the basis of material from Vallonnet and used the supposed replacement of Soergelia minor/brigittae by A. europaeus to assign localities like Fuente Nueva 3, Apollonia 1 and Venta Micena to certain ages. Crégut-Bonnoure (2007) considered A. europaeus a synonym of S. elisabethae. It certainly looks like Soergelia, but since no horn cores and no complete metapodials are known, it is not possible to know what kind of Soergelia it is. The Soergelia from Apollonia 1 has been described as $S$. brigittae, but its horn cores are not known (Kostopoulos, 1997). A metacarpal from Apollonia is robust and indicates an animal larger than S. minor; it approaches those of S. elisabethae. The geologically youngest (Süssenborn and Rastenberg) and first named species is S. elisabethae, which is also the largest (though differences are small) and which has massive horn cores, which taper rapidly towards the tip, and which are directed outwards and a little upwards and then curve forwards. The orientation, curvature and shape of the horn cores of $S$. elisabethae are closer to the older and more primitive ovibovine Megalovis, while the horn cores $S$. minor seem to be more evolved. As a consequence, Soergelia elisabethae does not seem to be a descendant of $S$. minor, but rather a parallel lineage that retained a primitive morphology. The first record of this lineage or group in Europe may have been in Apollonia 1 (or else in Vallonnet).

Ovis occurs in Cueva Victoria and in Apollonia 1 (Crégut Bonnoure, 2007). After this there is no record until about $500 \mathrm{ka}$.

The localities that record these events are Dorn Dürkheim, Happisburgh, and Apollonia 1. Dorn Dürkheim is below the Brunhes-Matuyama boundary, but has no more precise dating (Franzen et al., 2000). Happisburgh HSB3 is also below the Brunhes-Matuyama boundary, has a "warm" fauna and has been correlated to either stage 21 or 25 (Parfitt et al., 2010). These localities, with Alces latifrons, might be stage 21 and St. Prest, with Alces carnutorum, from before the cold peak of stage 22. Apollonia 1 has no other dating than by biochronology and was initially believed to be between 0.6 and 1.0 Ma old (Koufos \& Kostopoulos, 1997), later 
older dates have been proposed. Eucladoceros aff. giulii increased in size and is larger in Apollonia 1 and Akhalkalaki than in Atapuerca TD4-6. Equus major is believed to have given rise to E. suessenbornensis (Forsten, 1999). Various names have been applied to horses of this type: E. major, E. athanasiui and E. apolloniensis share metapodial size and proportions, as well as stenonid dental features. The latter was defined on the basis of fossils from Apollonia, while the apparently oldest record of E. suessenbornensis at Akhalkalaki. This might be an indication that Akhalkalaki is a little younger than Apollonia. Apollonia 1 records Praeovibos and Soergelia, which are suggestive of cold conditions. Apollonia 1 might date to stage 22 and the dispersal of the four taxa treated in this section, might be related to this cold stage.

\subsection{Striped hyaena and baboon.}

The baboon Theropithecus was known from a single tooth from Cueva Victoria (Gibert et al., 1995), while a phalanx was either attributed to Homo (e.g. Gibert \& Pérez-Pérez, 1989; Gibert et al., 2008) or to Theropithecus (Marínez-Navarro et al. 2005). There is also a record from India (Delson, 1993) and material from Ubeidiya has been tentatively assigned to this genus (Belmaker, 2010). Material from Pirro Nord was assigned to this genus (Rook et al., 2004), but seems now more probably to belong to Hystrix (Alba et al., 2014). Recently some new dental material was described from Cueva Victoria (Ferràndez-Cañadell et al., 2014), which thus remains the only European locality with this genus.

Hyaena striata (= H. hyaena), Pliocrocuta perrieri and Hyaena prisca are cited from numerous localities from the middle Middle Pleistocene onwards, such as Mosbach, Mauer, Hundsheim, L'Escale, Ponte Galería 3, Lunel Viel, etc. (Bonifay, 1971; Von Koenigswald \& Heinrich, 1999; Milli \& Palombo, 2005; CrégutBonnoure, 1996). These hyaenas have massive lower carnassials with a metaconid, as opposed to Pachycrocuta, which has massive carnassials without a metaconid and Crocuta which has slender carnassials without a metaconid. Pliocrocuta perrieri or Hyaena perrieri was present in Europe till about 2 or 1.8 Ma, when it was replaced by Pachycrocuta brevirostris. Today, Hyaena hyaena lives not only in Africa, but also in an area extending from Turkey to India. It seems likely that the Middle Pleistocene European hyaena is one species. It seems also more likely that it is more closely related to, or identical with, the living species, than with a species that lived in Europe before 1.8 Ma. The oldest European record after 1.8 Ma seems to be from Atapuerca TD8 (Rosell et al., 2010; Rodríguez et al., 2011). This is shortly after the appearance of Crocuta in Europe and it appears to be long before the demise of Pachycrocuta. So it seems that there was a long time that three hyaena species coexisted in Europe, though Hyaena hyaena does not seem to have been very common during the first 200-300 ky of its presence in Europe.

The appearance of the baboon is in Cueva Victoria, just below a palaeomagnetic reversal, that is either interpreted as the lower limit of the Brunhes or the Jaramillo (Ferràndez-Cañadell et al., 2014). Cueva Victoria has a Dama-like deer, that is comparable in size to the Middle Pleistocene species/samples and larger than the Early Pleistocene ones. If the locality is placed below the Jaramillo, this would extend the range (towards older) of a number of species, that are cited from there, whereas if it is placed just below the Brunhes, this does not extend the range of any species (towards younger). Other questions are, whether all specific determinations as used here are correct, or whether much value should be given to the known temporal range of rare species. A monograph with detailed descriptions is in press and this can be checked in the near future. For the time being, the locality is placed just below the Brunhes.

Atapuerca TD8 is placed just above the lower limit of the Brunhes (Parés et al., 2013). ESR and U-Th dating gave a mean age of $602 \pm 52$ ka (Falguères, et al., 1999) and luminescence dating gave and age of $820 \pm 140$ ka (Berger, et al., 2008). The fauna has various hold-overs from the Early Pleistocene, such as the small rhinoceros, here classified as Stephanorhinus etruscus, and Eucladoceros. Faunas that are correlated to stage 17 or even 19, such as Pakefield, Voigtstedt, West Runton and Tiraspol, have the large S. hundsheimensis and the giant deer Megaloceros savini and/or Megaceroides. The most likely correlation is of TD8 to stage 19 and the other faunas to stage 17 or the warm peak within stage 18.

Both Hyaena and Theropithecus came probably from or through SE Europe and SW Asia. Their dispersals may have been favoured by the same environments: relatively warm and open environments at the transition from stage 20 to 19. Alternatively, Cueva Victoria could be older than the Jaramillo, and in that case, the dispersal of the Theropithecus would coincide more or less with the appearance of a suid, a species of Eucladoceros and a new bear, which all are expected to have originated from different areas and environments.

\subsection{Steppe mammoth, straight tusked elephant, caballoid horses and lion}

The classic view on Mammuthus is that M. meridionalis evolved into the steppe mammoth M. trogontherii, acquiring more and thinner plates or lamellas in the molars, the transition of one species to the other occurring between the localities of Voigtstedt and Süssenborn. However, Franzen et al.(2000) described an older sample from Dorn Dürkheim 3 as M. trogontherii, which would not fit the model. Lister et al. (2005) presented a 
different model, in which $M$. trogontherii originated in East Asia and gradually spread towards Europe in a complex process of dispersal, hybridisation and gene flow. They recognized samples with bimodal distribution of the features, suggesting the presence of the two species. This is the case with Sinyaya Balka, Dorn Dürkheim and Voigtstedt. In this scenario, the latest M. meridionalis is also in Voigtstedt, but M. trogontherii appears earlier.

Elephas antiquus or Palaeoloxodon antiquus was described from Huéscar (Mazo, 1989), a site that has been considered to be latest Early Pleistocene in age. Nevertheless, Lister (2004) considered the first straight tusked elephant of Europe to be the one from Pakefield. If $M$. meridionalis and M. trogontherii have coexisted in Europe as different species, and if the last record of the latter species is in Voigtstedt, the demise of this species may have been related to the appearance of E. antiquus.

Caballoid horses differ from stenonid horses, such as E. suessenbornensis, in having U-shaped instead of V-shaped linguaflexids in the lower cheek teeth and in having longer protocones in the upper teeth. Eurasian caballoid horses include the domestic Equus caballus and its wild ancestor Equus ferus. Many fossil species have been named, which some include all in the living species (e.g. Azzaroli, 1990), while others recognize two or several separate species (respectively Forsten, 1999; Eisenmann, 1991). Equus mosbachensis is a very large species with robust metapodials. The living Equus ferus przewalskii is much smaller. There are also forms with less robust metapodials.

In a broad sense, caballoid horses replaced Equus suessenbornensis, but various opinions on how this occurred have been published. Forsten $(1988,1992)$ and Azzaroli (1990) were of the opinion that caballoid horses originated in North America and dispersed from there into Eurasia, where they occurred along with the large stenonid E. suessenbornensis. Eisenmann (1992) was of the opinion, that it is not possible to say where caballoids originated. Alberdi et al. (1995) included E. suessenbornensis in the caballoid group, which implies an older presence of caballoid species in Europe. In the latter scenario, the citation of both caballoid horses and E. suessenbornensis from the same locality, might be interpreted as variability in samples of an intermediate state of evolution. On the basis of DNA, Orlando et al. (2009) grouped caballoid horses with the new World Horses, separate from the Old World horses, including “sussemiones”. This would argue for an origin in the New World and dispersal into Eurasia. The localities where both types of horse are cited indicate then temporal overlap and, as a consequence, the dispersal of the former and the extinction of the latter are two events that are separated in time.

There is some discussion on some very old samples, such as Beresti, but Forsten (1992) cited the oldest European caballoid horses to be from Soleilhac, Tiraspol and Süssenborn. However, they are also present in Prezletice (Fejfar, 1993), Koneprusy (Von Koenigswald \& Heinrich, 1999), Westbury and possibly in West Runton (Lister et al., 2010). These are E. mosbachensis or similar. The different E. cf. germanicus is cited from Bad Frankenhausen (Von Koenigswald \& Heinrich, 1999). Equus mosbachensis and E. suessenbornensis are both large with robust limb bones and could be confused if the material is not good. They are occasionally cited from the same localities, but the co-occurrence of two so similar species raises the question how this functioned ecologically.

The oldest record of the lion Panthera leo is in Pakefield and Tiraspol (Stuart \& Lister, 2001; Nikiforova et al., 1971; Sala, 1996).

Most of the localities that record these events are of early Middle Pleistocene age, though Sinyaya

Balka and Dorn Dürkheim are below the Brunhes-Matuyama boundary (Shchelinski et al., 2010; Franzen et al., 2000). These are the localities, with, in the model of Lister et al. (2005), the earliest European Mammuthus meridionalis. Voigtstedt, Gombaszög, Prezletice, Pakefield and Tiraspol, are Middle Pleistocene, retain Mimomys, but not the small Stephanorhinus and large Eucladoceros, which are still present in Atapuerca TD8. The large Eucladoceros is probably also still present in Würzburg-Schalksberg, for which no rodents are known. If Atapuerca TD8 and Würzburg-Schalksberg are correlated to stage 19, Voigtstedt and Gombaszög could be correlated to younger warm period in stage 18 and Pakefield and Tiraspol, where the first caballoid horses and lion are recorded in stage 17. Alternatively, the correlations could be respectively to stage 17 and the first warm peak of stage 15. A correlation of Pakefield to stage 17 or 19 has been proposed previously (Parfitt et al., 2005). The transition of Mammuthus meridionalis to M. trogontherii, whatever its nature (evolution, replacement by dispersal, or a more complex process), could have been a relatively short process comprised between stages 20 (Sinyaya Balka and Dorn Dürkheim) and 17 (Pakefield and Tiraspol?) or 16 (Süssenborn).

\subsection{Reindeer, wooly rhinoceros, musk ox}

The first European record of the reindeer Rangifer, is from Süssenborn, Bad Frankenhausen and Bornhausen (H.D. Kahlke, 1969; R.D. Kahlke, 1995; Von Koenigswald \& Heinrich, 1999).

The first record in Europe of the wooly rhinoceros Coelodonta is in Bad Frankenhausen and Bornhausen (Kahlke \& Lacombat, 2008; Von Koenigswald \& Heinrich, 1999), but there is also one tooth from 
Süssenborn (IQW).

The oldest European record of the musk ox Ovibos is also in Süssenborn: originally described as $O$. suessenbornensis, but presently included in O. pallantis (H.D. Kahlke, 1963; Crégut-Bonnoure, 2007).

All of these taxa appear to be adapted to cold conditions or open environments. They all occur first in Süssenborn. This locality and Rastenberg have Soergelia elisabethae (Schaub, 1951; R.D. Kahlke, 1995) and Bad Frankenhausen has also Praeovibos priscus, again "glacial" elements. These localities, with these "cold" faunas, are in the area where the Elsterian has been defined and are said to be from Elsterian sediments (R.D. Kahlke, 1995; Von Koenigswald \& Heinrich, 1999). The Elsterian was an important glacial and its correlation to stage 16 seems likely. This is a long stage, and this would also explain, why there are relatively many localities with large mammals of this time, while the faunas of other glacials are known by fewer localities. The appearance of these taxa in Europe is probably by dispersal from Asia and due to the Elsterian glacial or cold conditions.

\subsection{Leopard and black bear}

The first Ursus thibetanus and the leopard Panthera pardus might be from Koneprusy C718 (Von Koenigswald \& Heinrich, 1999). For the leopard this is perhaps Voigtstedt, but the material is poor and the assignation incertain (Thenius, 1965). The oldest records of black bears were reviewed by Wagner et al. (2011) and none of the old records could with certainty be assigned to $U$. thibetanus.

Koneprusy C718 still has Mimomys and has an association that includes "cold" elements such as Praeovibos and Soergelia. It seems likely that the locality is to be correlated to stage 16. However, it does not seem likely that the leopard and black bear dispersed into Europe during such cold conditions as the musk oxen and reindeer and possibly this happened early or late in stage 16, but not during the maximum, if indeed Koneprusy is the locality that first records these species.

\subsection{Forest rhinoceros and dhole}

The forest rhinoceros Stephanorhinus kirchbergensis is known from Mosbach 2 by a huge amount of fossils and it is well known from younger localities. It is also recorded from the Frankenbacher Sande (Döppes \& Rosendahl, 2008). Some specimens of the large rhinoceros collection from Mauer were also assigned to this species (Schreiber, 2005). Like in Mauer, most rhinoceros material from Soleilhac belongs to S. hundsheimensis, but a single calcaneum was assigned to S. kirchbergensis (Lacombat, 2005). The species S. kirchbergensis is well represented in Tiraspol (Beliajeva \& David, 1971).

The last record of Xenocyon lycaonoides and the first record of the dhole Cuon are both in Mosbach 2 (Von Koenigswald \& Tobien, 1987). Cuon is also known from Hundsheim (Von Koenigswald \& Heinrich, 1999). Mosbach is a complex locality, in which the fauna from the lower part of the lithostratigraphic unit "Graues Mosbach" is called Mosbach 2 and the fauna from the upper part Mosbach 3 (Von Koenigswald \& Tobien, 1987; see also section 3.5.3.). The former has predominantly "interglacial” species and the latter "glacial". Possibly, this is an artificial division of a gradually changing fauna and possibly Xenocyon is from the lower part of the sequence and Cuon from somewhat higher.

Tiraspol still has the vole Mimomys, while Mosbach 2, Mauer and Soleilhac have Arvicola. Mauer has been dated: ten dates indicate ages from over 600 ka to over 400 ka (Wagner et al., 2010). Most dates are concentrated in or near stages 15 and 13. The fauna has mostly "warm” elements, including Hippopotamus, Sus scrofa and Elephas antiquus. Hundsheim and Mosbach 2 still have Stephanorhinus hundsheimensis, a species that was replaced by S. hemitoechus in faunas that are assigned to stages 12 and 11 (e.g. Arago sol G and Bilzingsleben; Van der Made, 2000, 2010; Lacombat, 2006). While Von Koenigswald \& Tobien (1987) did not cite S. hemitoechus at all, Von Koenigswald \& Heinrich (1999) cite it from Mosbach 2, and indeed this species does occur in Mosbach (NMM). Possibly, S. hundsheimensis is replaced by S. hemitoechus within the Mosbach sequence. The age of Mosbach 2 and 3 is not known precisely, but could correspond to stages 13 and 12. Hundsheim is predominantly a warm fauna, which could correspond to stage 13. The first representatives of this species were large, and they are still large in Süssenborn (stage 16), but in Mosbach and Mauer the a-coronate deer are already as small as the earliest coronate Cervus (Van der Made et al., 2014). Soleilhac might be stage 15 or 13, but not older because of the presence of Arvicola.

The extinction of Xenocyon and the dispersal of Cuon seem to have occurred within stage 13. The dhole, has a long previous record in China, where Cuon dubius is cited from early Early Pleistocene (Xue \& Zhang, 1991). Material described from Yunxian was assigned to "Xenocyon" dubius (Échassoux et al., 2008), but is very similar to the first European Cuon. If S. kirchbergensis is present in Mauer, it may well come from the upper part of the section (stage 13). The single calcaneum from Soleilhac might be older. Stephanorhinus kirchbergensis dispersed probably each interglacial from the east into Europe, and may have arrived further west in subsequent interglacials, reaching first Moldavia (Tiraspol), in a later glacial Germany and France (stage 13 or 
15) and if it reached Spain, this was much later and only in the very North.

\section{DISCUSSION: TD8 IN THE CONTEXT OF FAUNAL CHANGE}

The review in section 4 shows that the period around the Early-Middle Pleistocene transition was one of intense faunal change. The period from stage 37 till stage 13 has 12 climatic cycles, some of them minor ones. Ten discrete events could be documented; on average one event per $80 \mathrm{ky}$ and one event for each major climatic cycle, though some of the major cycles had two events and some of the minor ones none. Thirty six appearances of new taxa (by dispersal), 22 extinctions and ten cases of the evolution of one species into the other, are on average nearly four dispersals, over two extinctions and one new species by evolution per event. Future work may modify details of this scheme, and the planned descriptions of the other faunas from Gran Dolina may do so, but the general picture is not likely to change much.

This intensive faunal change occurred when the influence of the 100 ky eccentricity cycles on global climate increased, and when glacial cycles of this duration were established, reaching progressively colder temperatures (deMenocal, 1995; Shackleton, 1995). The faunal events were tentatively correlated to the isotope stages, by: 1) using information from localities dated by a variety of methods, 2) correlating dispersals of presumably cold adapted species to cold stages and warm adapted species to warm stages, 3) correlating faunal events to the most important of the chronologically close climatic events, 4) correlating preferentially subsequent events to subsequent stages and not to two moments in the same stage.

Some of the most important faunal events are correlated to the most significant climatic events (cold stages 36 and 16), but others not (warm stages 31/33, stage 27). Given the overall trend of decreasing temperatures, which is overprinted by the $100 \mathrm{ky}$ cycles, resulting subsequent cycles reaching lower temperatures, it might be expected that, faunal change was noted especially during cold stages in the appearance of new cold adapted ("glacial”) species. Surprisingly, this is not that clear: three of the four first events concern the appearance of species adapted to warm or moderate climates. Either the cold stages before stage 16 did not lead to the spread into mid-latitude Europe of species that we recognize as "glacial”, or these periods are poorly represented in the fossil record.

While the first dispersals of cold adapted species can be explained by colder or longer cold periods, it is less clear, why new species adapted to temperate or warm climates did not survive in the refugia in southern Europe (e.g. Stephanorhinus etruscus), or why new species adapted to such climates appeared (e.g. Cervus elaphus). In nine cases, an extinction of a lineage may have been related to the dispersal of a similar taxon, though there may have been a short overlap. This is the case with the following couples: Leptobos - Bison, Sus strozzii - Sus sp., Alces carnutorum - A. latifrons, Mammuthus meridionalis - M. trogontherii \& Elephas antiquus, Xenocyon - Cuon, Eucladoceros sp. T - E. giulii, E. giulii - E. aff. giulii, Sus sp. - Sus scrofa. Such related dispersals and extinctions are sometimes called "replacements". In elephants one species was replaced by a cold adapted and a warm adapted species. In other cases, there is no clear replacement and similar animals have a long overlap, as in the case of Pachycrocuta, which survived long after the appearance of Crocuta and Hyaena. During a million of years the European ecosystems supported only one species of hyaena and then for half a million it supported three. This could be related to the general increase in biodiversity. Faunal change was the result of complex processes and not the simple cyclical appearance of cold adapted species in mid-latitude Europe.

The Early Middle Pleistocene transition is situated in the middle of these climatic, environmental and faunal changes. It is conveniently defined by the Brunhes-Matuyama boundary. However, this is not at a moment of major faunal change. The fossil association from Atapuerca TD8 is situated directly above the Lower-Middle Pleistocene boundary, which is palaeomagnetically recorded in the underlaying level TD7. The combination of the two levels documents the fauna exactly at this boundary. This may well be the only place in all of Europe, where this is the case. The lowermost Middle Pleistocene fossil association of TD8 is characterized by the youngest records of the small rhinoceros (which we assume to be closely related to or a small variant of S. etruscus) and the otherwise exclusively Early Pleistocene genus Eucladoceros. It is also characterized by the first record of Hyaena. In future papers, the faunas from TD7 and lower levels will be described, documenting the latest Early Pleistocene of the Gran Dolina sequence.

\section{ConClusions}

The even and odd toed ungulates (Artiodactyla and Perissodactyla) from TD8 have been described and their evolution, systematics and the stratigraphic and biogeographic context have been discussed, leading to the 
following conclusions:

- Nine species of six families of ungulates are present: Equus altidens (Equidae) Stephanorhinus aff. etruscus (Rhinocerotidae), Sus scrofa (Suidae), Hippopotamus sp. (cf. tiberinus/georgicus) (Hippopotamidae), Bison voigtstedtensis (Bovidae) and Cervus elaphus, Eucladoceros aff. giulii, Megaceroides solilhacus, and Dama vallonnetensis (Cervidae).

- Equus altidens is a very slender equid, which may have evolved in Europe from a slightly less gracile species. If this is indeed the case, the transition is of stratigraphic interest and places Pirro Nord below Venta Micena. Since Equus altidens originated in Europe, it did not disperse from Africa to Europe, as has been suggested.

- The affinities of the small Stephanorhinus are still under discussion, but the record from TD8 is the latest well dated record of this small rhinoceros.

- There is a not very dense, but continuous record of Sus in Europe covering the period between the Olduvai and Jaramillo subchrons. Sus scrofa replaced a different species with verrucose canines around the end of the Jaramillo Subchron and the record of Sus scrofa from TD8 is one of the oldest known of this species.

- Hippopotamus may have dispersed three times to Europe during the Pleistocene: $H$. antiquus did so around 2 Ma, H. tiberinus/georgicus did so shortly before $1.2 \mathrm{Ma}$, and $H$. amphibius/incognitus did so during the later part of the Middle Pleistocene. The material from TD8 belongs probably to the second species.

- The Cervus elaphus from TD8 is one of the oldest records of this species in western Europe.

- The Eucladoceros from TD8 is the latest well dated record of this genus and one of the largest deer that ever lived.

- Megaceroides coexisted in TD8 with Eucladoceros. This is also the case in other levels of Gran Dolina, but this is uncommon: in Middle Pleistocene localities where Megaceroides coexists with another giant deer, it is with $M$. savini.

- Dama vallonnetensis is a fallow deer with gracile metapodials and a relatively low bifurcation between the brow tine and main beam. Until recently, fallow deer with antlers with three or just two tines and with robust metapodials were not recognized as a different group or lineage.

- A very small bovine from TD8 is identified as Bison voigtstedtensis, a species that is still not well known.

- The fauna of TD8 has been studied in the context of the faunal change at the end of the Early and beginning of the Middle Pleistocene. Ten faunal events are recognized, with 36 appearances by dispersal, 25 extinctions and ten species originating by evolution. These faunal events are tentatively correlated to isotope stages 37, 36, 33/31, 27, 22, 19, 18, 16, 16-15 and 13.

- The Lower-Middle Pleistocene boundary is conveniently taken at the palaeomagnetic Brunhes-Matuyama boundary. However, this is not the position of the major faunal events.

- TD8 is probably one of very few localities recording the earliest Middle Pleistocene fauna. It is right above the Brunhes-Matuyama boundary and is correlated to stage 19. It records the latest small Stephanorhinus etruscus, the latest Eucladoceros, and the earliest Hyaena.

\section{ACKNOWLEDGEMENTS}

Over many years, we were allowed access to material, used here for comparison, or received any other type of help from the following persons: L. Alcalá, F. Alférez, S.D. Aliev, F.X. Amprimoz, H. Astibia, V.S. Baigusheva, E. Baquedano, J. Bareiro, J.M. Bermúdez de Castro, G. Bossinski, C. Brauckmann, P.J.H. van Bree, P. Cabot, C. Cacho Quesada, E. Carbonell, B. Castillo, E. Cioppi, M. Comas, A. Currant, C. De Giuli, C. Guérin, F. Gusi, M. Dermitzakis, T. Engel, C. Ferrández-Cañadell, J.L. Franzen, E. Frey, M. Gamazo, J. Gibert Clols, L. Gibert, U. Göhlig, E. Gröning, J.H. Grünberg, O. Hampe, W.D. Heinrich, K.A. Hünermann, N. Ibañez, J.W.M. Jagt, H.D. Kahlke, R.D. Kahlke, J.A. Keiler, W. von Koenigswald, L. Kordos, D.S. Kostopoulos, G. Koufos, F. Lacombat, A. Lister, D. Lordkipanidze, H. de Lumley, H. Lutz, G. Lyras, D. Mania, U. Mania, M. Martínez Andreu, L. Maul, S. van der Mije, P.E. Moullé, W. Munk, M. Negro, M.R. Palombo, M. Patou-Mathis, H. Meller, E. Pons, K. Rauscher, J. Rodríguez, A. Rol, L. Rook, B. Sánchez Chillón, C. Smeenk, M. Sotnikova, K. Stefaniak, C. Strang, E. Tchernov, E. Turner, V.V. Titov, T.J. de Torres Perez-Hidalgo, E. Tsoukala, E. Vangengejm, I. Vislobokova, J. de Vos, R. van Zelst, and R. Ziegler. We thank the reviewers R. Croitor and R. Sardella for their constructive observations.

This research received support from project CGL2012-38434-C03, CGL2012-38358 and CGL-BOS-2012-34717 of the MinECo and the SYNTHESYS Project http:/www.synthesys.info/ which is financed by European Community Research Infrastructure Action under the FP7 "Capacities" Program (Synthesys AT-TAF-3663) and from Generalitat de Catalunya 2014 SGR 900. R. Blasco is a Beatriu de Pinós-A post-doctoral scholarship recipient (Generalitat de Catalunya and COFUND Marie Curie Actions, EU-FP7). 


\section{REFERENCES}

Abbazzi, L., 1995. Megaceroides obscurus from the Val di Chiana (Cava Liberatori, Tuscany, Centraly Italy, f.u. early Pleistocene). Remarks on the early evolution and systematics of Megaceroides. Bolletino della Società Paleontologica Italiana, 34(2): 223-234.

Abbazzi, L., R. Croitor \& A. David, 1999. Megaceroides obscurus (Azzaroli, 1953)(Mammalia, Cervidae) from Early Pleistocene Sites of Eastern Moldova. Acta zoologica cracoviense, 42(3): 377-392.

Abbazzi, L. \& F. Lacombat, 2005. Praemegaceros solilhacus (Robert, 1829). In: F. Lacombat (ed.) Les grands Mammifères fossiles du Velay. Annales des Amis du Musée Crozatier, 13-14: 118-120.

Agustí, J. (ed.). Geología y paleontología del Pleistoceno Inferior de Venta Micena. Paleontologia i Evolución, Memòria Especial 1: 1-297, 1 map.

Agustí, J., S. Moyà Solà \& J. Pons Moyà, 1987. La sucesión de mamíferos en el Pleistoceno inferior de Europa: proposición de una nueva escala bioestratigráfica. Paleontologia i Evolució , mem. esp. 1: 287-295.

Alba, D.M., S. Colombero, M. Delfino, B. Martínez-Navarro, M. Pavia \& L. Rook, 2014. A thorny question: The taxonomic identity of the Pirro Nord cervical vertebrae revisited. Journal of Human Evolution, 76: 92-106.

Alberdi, M.T., 2010. Estudio de los cavallos de los yacimientos de Fuente Nuevas-3 y Barranco León-5 (Granada). In: I. Toro, B. Martínez-Navarro \& J. Agustí (eds.) Ocupaciones humanas en el pleistoceno ingerior y medio de la Cuenca de Guadix-Baza. Arqueología Monografías. Junta de Andalucia, Consejería de cultura: 291-306.

Alberdi, M.T., Ortiz-Jaureguizar, E., Prado, J.L., 1998. A quantitative review of European stenonoid horses. Journal of Paleontology, 71(2): 371-387.

Alberdi, M.T. \& F.P. Bonadonna, (eds), 1989. Geología y paleontología del la Cuenca de Guadix-Baza. Trabajos sobre el Neogeno-Cuaternario, 11: 1-335, 1 map.

Alberdi, M.T. \& M.R. Palombo, 2013. The late Early to early Middle Pleistocene stenonoid horses from Italy. Quaternary International, 288: 25-44.

Alberdi, M.T., J.L. Prado \& E. Ortiz-Jaureguizar, 1995. Patterns of body size changes in fossil and living Equini (Perissaodactyla). Biological Journal of the Linnean Society, 54: 349-370.

Alberdi, M.T. \& A. Ruiz Bustos, 1985. Descripció y significado biostratgráfico y climático del Equus e Hippopotamus en el yacimento de Venta Micena (Granada). Estudios geológicos, 41: 251-261.

Alberdi, M.T. \& A. Ruiz-Bustos, 1987. Taxonomía y biostratigrafía de Equidae (Mammalia, Perissodactyla) en la cuenca de Guadix-Baza. Trabajos sobre el Neogeno-Cuaternario, 11: 239-271.

Arribas, A. \& G. Garrido, 2008. Los representantes más antiguos del género Capra (Bovidae, Artiodactyla, Mammalia) en el registro Euroasático (Foneleas P-1, Cuenca de guadix, España). In: A. Arribas (ed.) Vertebrados del Plioceno superior terminal en el suroeste de Europa: Fonelas P-1 y el Proyecto Fonelas. Cuadernos del Museo Geominero, 10:461-473.

Arzarello, M., F. Marcolini, G. Pavia, M. Pavia, C. Petronio, M. Petrucci, L. Rook \& R. Sardella, 2007. Evidence of earliest human occurrence in Europe: the site of Pirro Nord (Southern Italy). Naturwissenschaften, 94:107-112.

Arzarello, M., G. Pavia, C. Peretto, C. Petronio \& R. Sardella, 2012. Evidence of an Early Pleistocene hominin presence at Pirro Nord (Apricena, Foggia, southern Italy): P13 site. Quaternary International, 267: 5661.

Azanza, B. \& B. Sánchez, 1990. Les cervidés du Pléistocène Moyen d’Atapuerca (Burgos, Espagne). Quaternaire, 3-4: 197-212.

Azzaroli, A., 1948. Revisione della fauna dei terreni fluvio-lacustri del Valdarno Superiore, 3. I cervi fossili della Toscana con paricolare riguardo alle specie Villafrnchiane. Palaeontographia Italia, 43: 45-81, pls. 7-9.

Azzaroli, A., 1953. The deer of the Weybourn Crag and Forest Bed of Norfolk. The Bulletin of the British Museum (Natural History), 2(1): 3-96.

Azzaroli, A., 1983. Quaternary mammals and the "end-villafranchian" dispersal event -- a turning point in the history of Eurasia. Palaeogeography, Palaeoclimatology, Palaeoecology, 44 : 117-139.

Azzaroli, A., 1990. The genus Equus in Europe. In: Lindsay, E.H., Fahlbusch, V., Mein, P. (Eds.), European Neogene Mammal Chronology. Plenum Press, New York:. 339-356.

Azzaroli, A., 1992. The cervid genus Pseudodama n.g. in the Villafranchian of Tuscany. Palaeontographia Italica, 79: 1-41

Azzaroli \& Mazza, 1992 Azzaroli, A. \& P. Mazza, 1993. Large early Pleistocene deer from Pietrafitta lignite mine, central Italy. Paleontografia italica, 80: 1-24. 
Beliajeva, E. \& A.I. David, 1971. Fam. Rhinocerotidae Owen, 1845. In: K.V. Nikiforofa, E.I. Beliajeva, E.A. Vangengeim, N.A. Konstantinova, K.N. Negadaev-Nikonov (eds.) 1971. Pleistocene of Tiraspol. Publishing House Shtiintsa - Kisthinev: 124-134.

Bellucci, L., F. Bona, P. Corrado, D. Magri, I. Mazzini, F. Parenti, G. Scardia \& R. Sardella, 2014. Evidence of late Gelasian dispersal of African fauna at Coste San Giacomo (Anagni Basin, central Italy): Early Pleistocene environments and the background of early human occupation in Europe. Quaternary Science Reviews, 96: 72-85.

Bellucci, L., I. Mazzini, G. Scardia, L. Bruni, F. Parenti, A.G. Segre, E. Segre Naldini \& R. Sardella, 2012. The site of Coste San Giacomo (Early Pleistocene, central Italy): Palaeoenvironmental analysis and biochronological overview. Quaternary International 267: 30-39.

Bellucci, L., R. Sardella \& L. Rook, 2014-online. Large mammal biochronology framework in Europe at Jaramillo: The Epivillafranchian as a formal biochron. Quaternary International. http://dx.doi.org/10.1016/j.quaint.2014.11.012

Belmaker, M., 2010. The presence of large cercopithecine (cf. Theropithecus sp.) in the Ubeidiya formation (Early Pleistocene, Israel). Journal of Human Evolution, 58: 79-89.

Berger, G.W., Pérez-González, A., Carbonell, E., Arsuaga, J.L., Bermúdez de Castro, J.-M., Ku, T.-L., 2008. Luminescence chronology of cave sediments at the Atapuerca paleoanthropological site, Spain. Journal of Human Evolution 55: 300-311.

Bermúdez de Castro, J.M., J.L. Arsuaga, E. Carbonell \& J. Rodríguez (eds.), J.J. Fernández Moreno, E. Aguirre, E. Allué, J.L. Arsuaga, J.M. Bermúdez de Castro, I. Cáceres, J.I. Canudo, E. Carbonell, J.M. Carretero, G. Cuenca, J.C. Díez, A. Esquivel, Y. Fernández-Jalvo, N. García, D. García-Antón, A. Gracia, R. Huguet, C. Laplana, L. López-Polín, C. Lorenzo, J. van der Made, C. Mallol, B. Marquéz, A. Martín, I. Martínez, M. Mosquera, M.E. Nicolás, A. Ollé, A.I. Ortega, J.M. Parés, A. Pérez-González, P.J. Pérez, A. Pérez-Pérez, J. Rodríguez, A. Rosas, J. Rosell, R. Sala, A. Sánchez, S. Sarmiento, J. Vallerdú, J.M. Vergés, C. Cubillo, M. Antón, 1999. Atapuerca - Nuestros antecessores. Junta de Castilla y León: $1-221$.

Bermúdez de Castro J.M., Arsuaga J.L., Carbonell E., Rosas A., Martínez I. \& Mosquera M. 1997. A hominid from the Lower Pleistocene of Atapuerca, Spain: possible ancestor to Neandertals and modern humans. Science, 276: 1392-1395.

Blandamura, F. \& A. Azzarolii, 1977. L’’Ippopotamo maggiore” di Filipo Nesti. Atti della Accademia Nazionale dei Lincei, 374 Memorie, Classe die Scienze fisiche, matematiche e naturali, serie 8, vol. 14, sezione 2, no. 5: 169-188.

Bogićević, K. \& D. Nenadić, 2008. Early Pleistocene rodents (Rodentia, Mammalia) from Trlica near Pljevlja (Montenegro). Neues Jahrbuch für Geologie und Paläontologie, Abhandlungen, 247: 325-333.

Breda, M., S.E. Collinge, S.A. Parfitt \& A.M. Lister, 2010. Metric analysis of ungulate mammals in the early Middle Pleistocene of Britain, in relation to taxonomy and biostratigraphy I: Rhinocerotidae and Bovidae. Quaternary International, 228: 136-156.

Breda, M., A.M. Lister, 2013. Dama roberti, a new species of deer from the early Middle Pleistocene of Europe, and the origins of modern fallow deer. Quaternary Science Reviews, 69: 155-167.

Breda, M. \& M. Marchetti, 2005. Systematical and biochronological review of Plio-Pleistocene Alceini (Cervidae; Mammalia) from Eurasia. Quaternary Science Reviews, 24: 775-805.

Breda, M., C. Peretto \& U.. Thun Hohenstein, 2015. The deer from the early Middle Pleistocene site of Isernia la Pineta (Molise, Italy): revised identifications and new remains from the last 15years of excavation.. Geol. Journal. DOI: 10.1002/gj.2646.

Carbonell, E., J.M. Bermúdez de Castro, J.M. Parés, A. Pérez-González, A. Ollé, M. Mosquera, G. Cuenca-Bescós, N. García, D.E. Granger, R. Huguet, J. van der Made, M. Martinón-Torres, X.P. Rodríguez, A. Rosas, R. Sala, G.M. Stock, J. Vallverdú, J.M. Vergès, E. Allué, F. Burjachs, I. Cáceres, A. Canals, A. Benito, C. Díez, M. Lozano, A. Mateos, M. Navazo, J. Rodríguez, J. Rosell, J.L. Arsuaga, 2008. The first hominin of Europe. Nature, 452:465-469.

Carbonell, E., Estévez, J., Moyà Solà, S., Pons-Moyà, J., Agustá, J., de Villalta, J.F., 1981. “'Cueva Victoria" (Murcia, Esañ a): Lugar de ocupación humana mas antiguo de la Península Ibérica. Endins 8: 47-56.

Cerdeño, E., 1993. Remarks on the spanish Plio-Pleistocene Stephanorhinus etruscus (Rhinocerotidae). Comptes Rendus de l'Académie des Sciences, 317: 1363-1367.

Coltorti, M., A. Albianelli, A. Bertini, G. Ficcarelli, M.A. Laurenzi, G. Napoleone \& D. Torre, 1998. The Colle Curti mammal site in the Colfiorito area (Umbria-Marchean Apennine, Italy): geomorphology, stratigraphy, paleomagnetism and palynology. Quaternary International, 47-48: 107-116.

Coltorti, M., Ferraud, G., Marzoli, A., Peretto, C., Ton-That, T., Voinchet, P., Bahain, J.-J., Minelli, A., Thun-Hohenstein, U., 2005. New 40Ar/39Ar stratigraphic and paleoclimatic data on the Isernia La 
Pineta Lower Palaeolithic site, Molise, Italy. Quaternary International, 131: 11-22.

Crégut-Bonnoure, E., 1996. VIII Famille Hyaenidae. In: C. Guérin \& M. Patou-Mathis (eds.) Les Grands Mammifperes Plio-Pléistocènes d’Europe. Masson - Paris, Milano, Barcelona: 215-223.

Crégut-Bonnoure, É., 2007. Apport des Caprinae et Antilopinae (Mammalia, Bovidae) à la biostratigraphie du Pliocène terminal et du Pléistocène d'Europe. Quaternaire, 18(1): 73-97.

Crégut-Bonnoure, E. \& V. Dimitrijević, 2006. Megalovis balcanicus sp. nov. and Soergelia intermedia sp. nov. (Mammalia, Bovidae, Caprinae), new Ovibovini from the Early Pleistocene of Europe. Revue de Paléobiologie, 25(2): 723-773.

Crégut-Bonnoure, E. \& C. Guérin, 1996. Famille des Bovidae. In: C. Guérin and M. Patou-Mathis (eds.). Les grands mammifères Plio-Pléistocènes d'Europe. Masson - Paris, Milano, Barcelona: 62-95.

Croitor, R., 2011. A skull of Praemegaceros pliotarandoides (Cervidae, Mammalia) from the Taman peninsula (South-West Russia). Acta Palaeontologica Romaniae, 7: 113-121.

Croitor, R., 2006. Early Pleistocene small-sized deer of Europe. Hellenic Journal of Geosciences 41(1): 89-117.

Croitor, R. \& M.F. Bonifay, 2001. Étude préliminaire des cerfs du gisement pléistocène inférieur de Ceyssaguet (Haute-Loire). Paleo, 13: 129-144.

Croitor, R. \& D.S. Kostopoulos, 2004. On the systematic position of the large sized deer from Apollonia, Early Pleistocene, Greece. Paläontologische Zeitschrift, 78(1): 137-159.

De Giuli, C., 1987. Late Villafranchian faunas of Italy: the Selvella local fauna in the southern Chiana Valley Umbria. Palaeongographia Italica, 74: 11-50.

De Giuli, C. \& F. Masini, 1983. A new element of the Late Villafranchian (Tasso Unit) faunas of Italy: occurrence of Ovibovini (Bovidae, Artiodactyla, Mammalia) in the fauna of Casa Frata (Upper Valdarno, Tuscany). Bolletino della Societa Paleontologica Italiana, 22: 271-280.

De Giuli, C., F. Masini \& D. Torre, 1987. The latest Villafranchan faunas in Italy: the Pirro Nord fauna (Apricena, Gargano). Palaeontographia Italica, 74: 51-62.

Delson, E., 1993. Theropithecus fossils from Africa and India and the taxonomy of the genus. In: Jablonski, N.G. (Ed.), Theropithecus: The Rise and Fall of a Primate Genus. Cambridge University Press Cambridge: 157-189.

Delpech \& Guérin, 1996. Famille des Cervidae. In: C. Guérin and M. Patou-Mathis (eds.). Les grands mammifères Plio-Pléistocènes d'Europe. Masson - Paris, Milano, Barcelona: 47-62.

deMenocal, P. B., 1995. Plio-Pleistocene African Climate. Science, 270: 53-59.

Demuro, M. L.J. Arnold, J.M. Parés \& R. Sala, in press. Extended range luminiscence chronologies suggest potentially complex bone accumulation histories at the Early to Middle Pleistocene palaeontological site of Huéscar.1 (Guadix-Baza basin, Spain). Quaternary International.

Deng Tao \& Xue Xiangxu 1999. Chinese fossil horses of Equus and their environment. China Ocean Press: 1158, pls $1-20$.

Derevjanko, A.P., M.V. Šunjkov, A.K. Agadžanjan, L.Bulatovic, I.A. Vislobokova, V.A. Uljanov, A.A. Anojkin \& I. Medenica, 2012. Proucavanje Pleistocenskih slojeva u pecini Trlica na sjeveru crne gore. Davine Arheologicja u Crnoj Gori - Ancient Times Archaeology in Montenegro, 1: 45-58.

Di Stefano, G., 1995 a. Il daino pleistocenico dell'Eurasia. PhD thesis Università consorziate Modena, Bologna, Firenze, Roma: 1-219, pls. 1-25.

Di Stefano, G., 1995 b. Identification of fallow deer remains on the basis of its skeletal features. Taxonomical considerations. Bolletitino della Società Paleontologica Italiana, 34(3): 323-331.

Di Stefano, G. \& C. Petronio, 1998. Origin of and relationships among Dama-like cervids in Europe. Neues Jahrbuch für Geologie und Paläontologie, Abhandlungen, 207(1): 37-55.

Di Stefano, G. \& C. Petronio, 2002. Systematics and evolution of the Eurasian Plio-Pleistocene tribe Cervini (Artiodactyla, Mammalia). Geologica Romana, 36: 311-334.

Döppes, D. \& W. Rosendahl, 2008. Die Frankenbacher Schotter bei Heilbronn - ein wichtiges Archiv aus der Zeit des Homo heidelbergensis. Abhandlungen der Geologischen Bundesanstalt, 62: 139-143.

Duval, M., Falguères, C., Bahain, J.-J., Grün, R., Shao, Q., Aubert, M., Hellstrom, J., Dolo, J.-M., Agustí, J., Martinez-Navarro, B., Palmqvist, P., Toro-Moyano, I., 2011. The challenge of dating early Pleistocene fossil teeth by the combined uranium series electron spin resonance method: the Venta Micena palaeontological site. Journal of Quaternary Science, 26: 603-615.

Duval, M., Falguères, C., Bahain, J.-J., Grün, R., Shao, Q., Aubert, M., Dolo, J.-M., Agusti, J., Martínez-Navarro, B., Palmqvist, P., Toro-Moyano, I., 2012. On the limits of using combined U-series/ESR method to date fossil teeth from two Early Pleistocene archaeological sites of the Orce area (Guadix-Baza basin, Spain). Quaternary Research, 77: 481-482.

Faure, M. \& C. Guérin, 1984. Sus strozzii et Sus scrofa, deux mammifères artiodactyles, marquers des paleoenvironnements. Palaeogeography, Palaeoclimatology, Palaeoecology, 48: 215-228. 
Echassoux, A., A.M. Moigne, P.É. Moullé, Li Tianyuan, Feng XiaoBo \& Li Wensen, 2008. Les faunes de grands mammifperes du site de l’homme Yunxian. In: H. de Lumley \& Li Tianyuan (eds.) Le site de l’homme de Yunxian. CNRS Éditions - Paris: 253-364.

Eisenmann, V. 1979. “Les métapodes d’Equus sensu lato (Mammalia, Perissodactyla)”. Geobios, 12: 863-886.

Eisenmann, V., 1986. Les équidés du Pléistocène d’Oubeidiyeh (Israël). In: Tchernov, E. (ed.), Les Mammifères du Pléistocène Inférieur de la Vallée du Jourdain à Oubeidiyeh. Mémoires et Travaux du Centre de Recherche Français de Jérusalem, 5: 191-212.

Eisenmann, V., 1991. Les Chevaux Quaternaires européens (Mammalia, Perissodactyla). Taille, typologie, biostratgraphie et taxonomie. Geobios, 24(6): 747-759.

Eisenmann, V., 1992. Origins, dispersals, and migrations of Equus (Mammalia, Perissodactyla). Courier Forschuntsinstitut Senckenberg, 153: 161-170.

Eisenmann, V., M.T. Alberdi, C. de Giuli \& U. Staesche 1988. Methodology. In M. Woodburne \& P. Sondaar (eds) Studying Fossil Horses, Volume 1. Leiden, E. J. Brill: 1-71.

Eisenmann, V \& T. Kuznetsova, 2004. Early Pleistocene equids (Mammalia, Perissodactyla) of Nalaikha, Mongolia, and the emergence of modern Equus Linnaeus, 1758. Geodiversitas, 26(3): 535-561.

Eisenmann, V. \& M. Mashkour, 1999. the small equis of Binagady (Azerbaidjan) and Qazvin (ran): E. hemionus binagadensis nov. subsp. and E. hydruntinus. Geobios, 32/1: 105-122.

Falguères, C., Bahain, J.-J., Yokoyama, Y., Arsuaga, J.L., Bermudez de Castro, J.M., Carbonell, E., Bischoff, J.L., Dolo, J.-M., 1999. Earliest humans in Europe: the age of TD6 Gran Dolina, Atapuerca, Spain. Journal of Human Evolution, 37: 343-352.

Faure, M., 1985. Les hippopotames Quaternaires non-insulaires d’Europe occidentale. Nouvelles Archives du Muséum d'Histoire naturelle de Lyon, 23: 13-79, pls. 1-4.

Faure, M. \& C. Guérin 1992. La grande faune d'Europe occidentale au Pléistocène moyen et supérieur et ses potentialités d'information en préhistoire. Mémoires de la Société de France, n.s., 160: 77-84.

Faure, M. \& C. Guérin, 1984. Sus strozzii et Sus scrofa, deux marnmifères artiodactyles, marqueurs des paleoenvironnements. Palaeogeography, Palaeoclimatology, Palaeoecology, 48: 215-228.

Fejfar, O., 1993. Die Fauna aus den limnischen Ablagerungen fon Prezletice bei Prag und ihre biochronologische Aussage. Jahrbuch des Römish-GermanischenZentralmuseums Mainz, 40: 103-113, pls. 4-8.

Ferràndez-Cañadell, C., F. Ribot, L. Gibert, 2014. New fossil teeth of Theropithecus oswaldi (Cercopithecoidea) from the Early Pleistocene at Cueva Victoria (SE Spain). Journal of Human Evolution, 74: 55-66.

Fischer, K.H., 1965. Bisonreste (Bison schoetensacki voigtstedtensis ssp. n.) aus den altpleistozänen Tonen von Voigstsedt in Thüringen. Paläontologische Abhandlungen, Abteilung A, 2(2-3): 363-378, pls. 8-12.

Flerov, C.C., 1975. Die Bison-Reste aus den Travertinen von Weimar-Ehringsdorf. In: H.D. Kahlke (ed.) III. Internationales Paläontologisches Kolloquium 1968. Das Pleistozän von Weimar-Ehringsdorf Teil 2. Abhandlungen des Zentralen Geologischen Instituts. Paläontologische Abhandlungen, 23: 171-199.

Forsten, A. 1973. Evolutionary changes in the metapodials of fossil horses. Commentationes Biologicae, 69: 3-18.

Forsten, A., 1988. Middle Pleisotcene replacement of stenonid horses by caballoid horses - ecological implications. Palaeogeography, Plaeoclimatology, Palaeoecology, 65: 23-33.

Forsten, A. 1990. Old World "Asses". Quartär-Paläontologie, 8: 71-78.

Forsten, A., 1992. Mitochondria-DNA time-table and the evolution of Equus: comparison of molecular and paleontological evidence. Annales Zoologici Fennici, 28: 301-309.

Forsten, A. 1999. A review of Equus stenonis Cocchi (Perissodactyla, Equidae) and related forms. Quaternary Science Reviews, 18: 1373-1408.

Forsten, A. \& R. Ziegler, 1995. The horses (Mammalia, Equidae) form the early Wuermian of Villa Seckendorff, Stuttgart-Bad Cannstatt, Germany. Stuttgarte Beiträge zur Naturkunde Serie B (Geologie und Paläontologie), 224: 1-22.

Fortelius, M., Mazza, P., Sala, B., 1993. Stephanorhinus (Mammalia: Rhinocerontidae) of the western European Pleistocene, with a revision of S. etruscus (Falconer, 1868). Palaeontolographia Italica 80, 63-155.

Franzen, J.L., Gliozzi, E., Jellinkek, T., Scholger, R., Weidenfeller, M., 2000. Die spätpleistozäne Fossillagerstätte Dorn-Dürkheim 3 und ihre Bedeutung für die Rekonstruktion der Entwicklung des rhenishen Flusssystems. Senkenbergiana Lethaea, 80(1): 305-353.

Freudenthal, M., T. Meyer \& A.J. van der Meulen, 1976. Preliminary record on a field campaign in the continental Pleistocene of Tegelen (The Netherlands). Scripta Geologica, 34: 1-27.

García, N. \& J.L. Arsuaga, 2001. Les carnivores (Mammalia) des sites dus Pléistocène ancien et moyen d'Atapuerca (Espagne). L'Anthropologie, 105(1): 83-94.

Garrido, G., 2008a. La asociación de los géneros Croizetoceros, Metacervoceros y Eucladoceros (Cervidae, Artiodactyla, Mammalia) en el Yacimiento de Foneleas P-1 (Cuenca de Guadix, Granada). In: A. 
Arribas (ed.) Vertebrados del Plioceno superior terminal en el suroeste de Europa: Fonelas P-1 y el Proyecto Fonelas. Cuadernos del Museo Geominero, 10: 365-396.

Garrido, G., 2008b. Praeovibos sp.(bovidae, Artiodactyla, Mammalia): la primera cita del género en el Plioceno superior terminal de Eurasia (Fonelas p-1, cuenca de Guadix, Granada). In: A. Arribas (ed.) Vertebrados del Plioceno superior terminal en el suroeste de Europa: Fonelas P-1 y el Proyecto Fonelas. Cuadernos del Museo Geominero, 10: 475-488.

Geraads, D., C. Guérin \& M. Faure, 1996. Les suidés du Pléistocène Ancien d'Oubeidiyeh (Israel). Mémoires et Travaux du Centre de Recherches français de Jérusalem, 5 : 93-105.

Gibert, J., A. Arribas, B. Martínez, S. Albadalejo, R. Gaete, L. Gibert, C. Peñas \& R. Torrico, 1992. Síntesis cronoestratigráfica del Pleistoceno inferior de la región de Orce. In: J. Gibert (ed) Proyecto Orce-Cueva Victoria (1988-1992) Presencia humana en el Pleistoceno inior de Granada y Murcia. Museo de Prehistoria Josep Gibert - Orce: 107-114, figure after p. 114.

Gibert, J., Campillo, D., Arqués, J.M., García-Olivares, E., Borja, C., Lowenstein, J.M., 1998. Hominid status of the Orce cranial fragment reasserted. Journal of Human Evolution, 34: 203-217.

Gibert, J., Gibert, L.I., Albadalejo, S., Ribot, F., Sánchez, F., Gibert, P., 1999. Molar tooth fragment BL5-O: the oldest human remain found in the Plio-Pleistocene of Orce (Granada province, Spain). Human Evolution, 14: 3-19.

Gibert, J., L. Gibert, F. Ribot, C. Ferràndez-Cañadell, A. Iglesias, M. Walker, 2008. CV-0, an early Pleistocene human phalanx from Cueva Victoria (Cartagena, Spain). Journal of Human Evolution, 54: 150-156.

Gibert, J. \& A. Pérez-Pérez, 1989. A human phalanx from the Lower Palaeolithic site of Cueva Victoria (Murcia, Spain). Human Evolution, 4: 307-316.

Gibert, J., F. Ribot, L. Gilbert, M.G. Leakey, A. Arribas \& B. Martínez-Navarro, 1995. Presence of the Cercopithecid genus Theropithecus in Cueva Victoria (Murcia, Spain). Journal of Human Evolution, 28: 487-493.

Giles Pacheco, F., A. Santiago, J.M. Gutiérrez, J.M. López-García, H.-A. Blain, G. Cuenca-Bescós, J. van der Made, I. Cáceres d \& N. García, 2011. The paleontological site in the Sierra del Chaparral (Villaluenga del Rosario, Cádiz-Spain). Quaternary International, 243: 92-104.

Gromova, V.L. \& I.A. Dubrovo, 1975. Fossile Pferede aus dem Faunenkomplex von Tiraspol. Quartärpaläontologie, 1: 107-124.

Guérin, C., 1980. Les Rhinoceros (Mammalia, Perissodactyla) au Pléistocène Superieur en Europe occidentale; comparasion avec les espèces actuelles. Documents des Laboratoires de Géologie Lyon, 79(1-3):1-1185.

Guérin, C., 1996 a. Famille des Suidae. In: C. Guérin \& M. Patou-Mathis (eds) Les Grands Mammifères PlioPléistocènes d'Europe. Masson -Paris: 40-43.

Guérin, C., 1996 b. Famille des Hippopotamidae. In: C. Guérin \& M. Patou-Mathis (eds) Les Grands Mammifères Plio-Pléistocènes d’Europe. Masson -Paris: 44-47.

Guérin, C., 1996 c. Famille des Rhinocerotidae. In: C. Guérin \& M. Patou-Mathis (eds) Les Grands Mammifères Plio-Pléistocènes d'Europe. Masson -Paris: 111-121.

Guérin, C., 1996 d. Famille des Equidae. In: C. Guérin \& M. Patou-Mathis (eds) Les Grands Mammifères PlioPléistocènes d’Europe. Masson -Paris: 121-131.

Guérin, C., Dewolf, Y., Lautridou, J.P., 2003. Révision d‘un site paléontologique célèbre Saint-Prest (Chartres, France). Geobios, 36: 55-82.

Guérin, C. \& M. Faure, 1997. The wild boar (Sus scrofa priscus) from the p-Villafranchian lower Pleistocene of Untermassfeld. In: Kahlke, R.D. (ed.), Das Pleistozän von Untermassfeld bei Meiningen (Thüringen). Dr Rudolf Habelt GMBH - Bonn: 375-383, pls. 63-67.

Guerrero-Alba, S. \& P. Palmqvist 1997. Estudio morfométrico del caballo de Venta Micena (Orce, Granada) y su comparación con los équidos modernos y del Plio-Pleistoceno en el viejo y nuevo mundo. Paleontologia i Evolució, 30-31: 93-148.

Guthrie, R.D. 1990. Frozen fauna of the Mammoth steppe. The story of Blue Babe. The University o f Chicago Press- Chicago \& London: 1-323.

Hadjouis, D., 1990. Megaceroides algericus (Lydekker, 1890), du gisement des Phacochères (Alger, Algérie). Étude critique de la position systématique de Megaceroides. Quaternaire, 1(3-4): 247-258.

Heintz, E., 1970. Les cervidés Villafranchiens de France et d'Espagne. Mémoires du Muséum National d'Histoire Naturelle, nouv. sér., série C, Sciences de la Terre 22, 1-303, 40 pls., 319 figs., 131 tables.

Hu Changkang \& Qi Tao, 1978. Gongwangling Pleistocene mammalian fauna of Lantian, Shaanxi. Palaeontologia Sinica, 155, new series C, 21: 1-64, pls 1-15.

Internation Comission on Zoological Nomenclature, 1999. International code of zoologial nomenclature. Fourth Edition. The International Trust for Zoological Nomenclature - London: 1-306. 
Jánossy, D., 1986. Pleistocene vertebrate faunas of Hungary. Académiai Kiadó - Budapest: 1-208.

Kahlke, H.-D. 1963. Ovibos aus den Kiesen von Süsenborn. Ein Beitrag zur Systematik und Phylogenie der Ovibovini und zur Stratigraphie des Pleistozäns. Geologie, 12(8): 942-972.

Kahlke, H.D. (ed.), 1965a. Das Pleistozän von Voigtstedt. Paläontologische Abhandlungen, Abteilung A, 2/2-3: 221-692, pls. 1-40, 2 maps.

Kahlke, H.D., 1965b. Die Cerviden-Reste aus den Tonen von Voigtstedt in Thüringen. Paläontologische Abhanlungen, A 2(2/3): 379-426, pls. 13-22.

Kahlke, H.D. (ed.), 1969b. Das Pleistozän von Süssenborn. Paläontologische Abhandlungen, Abteilung A, 3/3-4: 367-788, pls. 1-66, tables 1-34.

Kahlke, H.D., 1969 a. Die Soergelia-Reste aus den Kiesen von Süssenborn bei Weimar. Paläontologische Abhandlungen, A 3(3/4): 531-545.

Kahlke, H.D., 1995. Die Abfolge plio-/pleistozäner Säugetierfaunen in Thüringen (Mittledeutschland). Cranium, 12/1: 5-18.

Kahlke, H.-D., 1997. Die Cerviden-Reste aus dem Untepleistozän von Untermassfeld. In: Kahlke, R.D. (ed.), Das Pleistozän von Untermassfeld bei Meiningen (Thüringen). Dr Rudolf Habelt GMBH - Bonn: 181275.

Kahlke, H.D., 2001a. Neufunde von Cerviden-Reste aus dem Unterpleistozän von Untermassfeld, In: R.D. Kahlke (ed.) Das Pleistozän von Untermassfeld bei Meinigen (Thüringen), Teil 2.

Römisch-Germanisches Zentralmuseum Forschungsinstitut für Vor- und Frühgeschichte. Monographiën, 40(2): 461-482, pls 72-76.

Kahlke, H.D., 2001b. Die Rhinocerotiden-Reste aus dem Unterpleistozän von Untermassfeld, In: R.D. Kahlke (ed.) Das Pleistozän von Untermassfeld bei Meinigen (Thüringen), Teil 2. Römisch-Germanisches Zentralmuseum Forschungsinstitut für Vor- und Frühgeschichte. Monographiën, 40(2): 501-555, pls 79-91.

Kahlke, R.D. 1994. Die Entstehungs-, Entwicklungs- und Verbreitungsgeschichte des oberpleistozänen Mammuthus-Coelodonta-Faunenkomplexes in Eurasien (Grosssäuger). Abhandlungen des Senckenbergischen Naturforschenden Gesellschaft, 546: 1-164.

Kahlke, R.D., 1995. Die Abfolge plio-/pleistozäner Säugierfaunen in Thüringen (Middeldeutschland). Cranium, 12/1: 5-18.

Kahlke, R.D. (ed.), 1997a. Das Pleistozän von Untermassfeld bei Meiningen (Thüringen). Dr Rudolf Habelt GMBH, Bonn: 1-418, pls. 1-67.

Kahlke, R.D., 1997b. Die Hippopotamus-Reste aus dem Unterpleistozän von Untermassfeld. In: R.D. Kahlke (ed.) Das Pleistozän von Untermassfeld bei Meinigen (Thüringen), Teil 1. Römisch-Germanisches Zentralmuseum Forschungsinstitut für Vor- und Frühgeschichte. Monographiën, 40(1): 277-374, plates 45-62.

Kahlke, R.D. (ed.), 2001 a/b. Das Pleistozän von Untermassfeld bei Meiningen (Thüringen). Teil 2 / Teil 3. Dr Rudolf Habelt GMBH, Bonn:419-698, pls. 68-131, 1 map / 699-1030, pls. 132-151, maps 1-15.

Kahlke, R.D., 2001c. Schädelsreste von Hippopotamus aus dem Unterpleistozän von Untermassfeld. In: R.D. Kahlke (ed.) Das Pleistozän von Untermassfeld bei Meiningen (Thüringen). Teil 2. Dr Rudolf Habelt GMBH, Bonn: 483-500, pls. 77-78.

Kahlke, R.D., 2006. Untermassfeld. A late EarlyPleistocene (Epivillafranchain) fossil site near Meinignen (Thuringia, Germany) and its position in the development of the European mammal fauna. British Archaeological Reports International Series, 1578: 1-141, supplement maps 1-15.

Kahlke, R.D., 2007. Late Early Pleistocene European large mammals and the concept of an Epivillafranchian biochron. Courier Forschungsinstitut Senckenberg, 259: 265-278.

Kahlke, R.D. \& F. Lacombat, 2008. The earliest immigration of woolly rhinoceros (Coelodonta tologoijensis, Rhinocerotidae, Mammalia) into Europe and its adaptive evolution in Palaearctic cold stage mammal faunas. Quaternary Science Reviews, 27: 1951-1961.

Kaiser, T.M. \& R. Croitor, 2004. Ecological interpretations of early Pleistocene deer (Mammalia, Cervidae) from Ceyssaguet (Haute-Loire, France). Geodiversitas 26 (4) : 661-674.

Koenigswald, W. von \& W.D. Heinrich, 1999. Mittelpleistozäne Säugetierfaunen aus Mitteleuropa - der Versuch einer biostratigraphischen Zuordnung. Kaupia, 9: 53-112.

Koenigswald,W. von \& H. Tobien, 1987. Bemerkungen zur Alterstellung der pleistozänen Mosbach-Sande bei Wiesbaden. Geologisches Jahrbuch Hesse, 115: 227-237.

Kostopoulos, D.S., 1997. The Plio-Pleistocene artidocatyls (Vertebrata, Mammalia) of Macedonia 1. The fossilferous site “Apollonia-1", Mygdonia basin of Greece. Geodiversitas, 19(4): 845-875.

Koufos, G. \& D. Kostopoulos, 1997. Biochronology and succession of the Plio-Pleistocene macromammalian localities of Greece. In: J.P. Aguilar, S. Legendre \& J. Michaux (eds) Actes du Congrès BiochroM’97. 
École Pratique des Hautes Études. Mémoires et Travaux de l’Institut de Montpellier, 21: 619-634.

Kretzoi, M., 1938. Die Raubtiere von Gombaszög nebst einer Übersicht der Gesamtfauna (ein Beitraz zur Stratigraphie des Altquartaers). Annales Mesei Nationalis Hungarici, 31: 88-137.

Lacombat, F., 2005. Les rhinocéros fossiles des sites préhistoriques de l’Europe méditerranéenne et du Massif Central: Paléontologie et implications biochronologiques. BAR International Series, 1419: 1-175.

Lacombat, F., 2006. Morphological and biometrical differentiation of the teeth from Pleistocene species of Stephanorinus (Mammalia, Perissodactylas, Rhinocerotidae) in Mediterranean Europe and the Massif Central, France. Palaeontographica, Abt. A 274, 71-111.1-175.

Lacombat, F., 2009. Biochronologie et grands mammifères au Pléistocène Moyen et Supérieur en Europe occidentale: l'apport des Rhinocerotidae (Genre Stephanorhinus). Quaternaire, 20(4): 429-435.

Leonardi, G. \& C. Petronio, 1976. The fallow deer of the european Pleistocene. Geologica Romana, 15: 1-67.

Lister, A.M. 1993. The stratigraphical significcnace of deer species in the Cromer Forest -bed Formation. Journal of Quaternary Science, 8(2): 95-108.

Lister, A.M., 1996. The morphological distinction between bones and teeth of fallow deer (Dama dama) and red deer (Cervus elaphus). International Journal of Osteoarchaeology, 6, 119-143.

Lister, A.M., 2004. Ecological Interactions of elephantids in Pleistocene Eurasia: Palaeoloxodon and Mammuthus. In: N. Goren-Inbar \& J.D. Speth (eds.) Human Paleoecology in the Levantine Corridor. Oxford - Oxbow Press: 53-60.

Lister, A.M., S.A. Parfitt, F.J. Owen, S.E. Collinge \& M. Breda, 2010. Metric analysis of ungulate mammals in the early Middle Pleistocene of Britain, in relation to taxonomy and biostratigraphy II: Cervidae, Equidae and Suidae. Quaternary International, 228: 157-179.

Lister, A.M., A.V. Sher, H. van Essen \& G. Wei, 2005. The pattern and process of mammoth evolution in Eurasia. Quaternary International, 126-128: 2005, 49-64.

López-García, J.M., G. Cuenca-Bescós, H.A. Blain, I. Cáceres, N. García, J. van der Made, J.M. Gutierrez, A. Santiago, F. Giles Pacheco, 2012. Biochronological data inferred from the Early Pleistocene Arvicolinae (Mammalia, Rodentia) of the el Chaparral site (Sierra del Chaparral, Cádiz, southwestern Spain). Journal of Vertebrate Paleontology, 32(5):1149-1156.

Lumley, H., de, Kahlke, H.-D., Moigne, A.-M., Moullé, P.-E., 1988. Les faunes de grands mammifères de la grotte du Vallonnet Roquebrune-Cap-Martin, Alpes-Maritimes. L’Anthropologie, 92 (2): 465-469.

Made, J. van der, 1989. The bovid Pseudoeotragus seegrabensis nov. gen. nov. sp. from the Aragonian (Miocene) of Seegraben near Leoben (Austria). Proceedings of the Koninklijke Nederlandse Akademie van Wetenschappen, serie B, 92 (3): 215-240.

Made, J. van der, 1990 a. Iberian Suoidea. Paleontologia i Evolució, 23: 83-97.

Made, J. van der, 1990 b. A range chart for European Suidae and Tayassuidae. Paleontologia i Evolució, 23: 99104.

Made, J. van der, 1996. Listriodontinae (Suidae, Mammalia), their evolution, systematics and distribution in time and space. Contributions to Tertiary and Quaternary Geology, 33(1-4): 3-254, tables on microfiche 54 pp.

Made, J. van der 1997 e. Los Suoidea de la Península Ibérica. In (J.P. Calvo \& J. Morales, eds.) Avances en el conocimiento del Terciario Ibérico: 109-112.

Made, J. van der, 1998 a. Ungulates from Gran Dolina (Atapuerca, Burgos, Spain). Quaternaire, 9(4): 267-281.

Made, J. van der, 1998 b. A preliminary note on the cervids from Bilzingsleben. Praehistoria Thuringica, 2: 108-122.

Made, J. van der, 1999 a. Ungulates from Atapuerca-TD6. Journal of Human Evolution, 37(3-4): 389-413.

Made, J. van der, 1999 b. Superfamily Hippopotamoidea. In (G. Rössner \& K. Heissig, eds.) The Miocene land mammals of Europe. Verlag Dr. Friedrich Pfeil, München: 203-208.

Made, J. van der, 1999 c. Artiodactylos del yacimiento mesopleistoceno de Galería (Sierra de Atapuerca). In E. Carbonell, A. Rosas \& C. Diez (eds.): Ocupaciones humanas y paleoecología del yacimiento de Galería. Junta de Castilla y León: 143-167

Made, J. van der, 2000. A preliminary note on the rhinos from Bilzingsleben. Praehistoria Thuringica, 4: 41-64.

Made, J. van der, 2001. Les ongulés d'Atapuerca. Stratigraphie et biogéographie. L'Anthropologie, 105 (1): 95-113.

Made, J. van der, 2010. The rhinos from the Middle Pleistocene of Neumark Nord (Saxony-Anhalt). Veröffentlichungen des Landesamtes für Archäologie, 62: 432-527.

Made, J. van der, 2011 a. Biogeography and climatic change as a context to human dispersal out of Africa and within Eurasia. In Carrion J.S., Rose J., Stringer C. (editors): Ecological scenarios for human evolution during the early and Middle Pleistocene in the western palaeartic. Quaternary Science Reviews, 30: 1353-1367. 
Made, J. van der, 2011 b. Observations on the fauna from Terra Amata. In: H. de Lumley (ed.) Terra Amata, Nice, Alpes-Maritimes, France. Tome II. Palynologie, Anthracologie, Faunes des vertébrés, Molusques, Paléoenvironnements, Paléoanthroplogie. CNRS Éditions, Paris: 277-284.

Made, J. van der, 2012. L'Antilope Eotragus sansaniensis du Miocène Moyen de Sansan. Mémoires du Muséum National d'Histoire Naturelle, 203: 145-199.

Made, J. van der, 2013. First description of the large mammals from the locality of Penal, and updated faunal lists for the Atapuerca ungulates - Equus altidens, Bison and human dispersal into Western Europe Quaternary International, 295: 36-47.

Made, J. van der, 2014. Late Pleistocene European and Late Miocene African acceleration of faunal change in relation to climate and as a background to human evolution. Quaternary International, 326-327: 431-447.

Made, J. van der, 2015. The latest Early Pleistocene giant deer Megalcoeros novocarthaginiensis n. sp. and the fallow deer Dama cf. vallonnetensis from Cueva Victoria (Murcia, Spain). Mastia, 10: 269-323.

Made, J. van der, 2015. The rhinoceros Stephanorhinus aff. etruscus from the latest Early Pleistocene of Cueva Victoria (Murcia, Spain). Mastia, 10: 345-369.

Made, J. van der, E. Aguirre, M. Bastir, Y. Fernández Jalvo, R. Huguet, C. Laplana, B. Márquez, C. Martínez, M. Martinón, A.Rosas, J. Rodríguez, A. Sánchez, S. Sarmiento, J.M. Bermúdez de Castro, 2003. El registro paleontológico y arqueológico de los yacimientos de laTrinchera del Ferrocarril en la Sierra de Atapuerca. Coloquios de Paleontología, spec. vol. 1: 345-372.

Made, J. van der, J.A. Carlos Calero \& M.Á. Mancheño, 2008. New material of the goat Capra alba from the Lower Pleistocene of Quibas (Spain) - notes on sexual dimorphism, stratigraphic distribution and systematics. Bolletino della Società Paleontologica Italiana, 47(1): 13-23.

Made, J. van der \& V. Dimitrijević, in press. Eucladoceros montenegrensis n. sp. and other Cervidae from the Lower Pleistocene of Trlica (Montenegro). Quaternary International.

Made, J. van der \& R. Grube, 2010. The rhinoceroses from Neumark-Nord and their nutrition. In: D. Höhne \& W. Schwarz (eds) "Elefantentreich - Eine Fossilwelt in Europa". Landesamt für Denkmalpflege und Archälogie Sachsen-Anhalt \& Landesmuseum für Vorgeschichte, Halle: 383-394.

Made, J. van der \& S. Moyà-Solà, 1989. European Suinae (Artiodactyla) from the Late Miocene onwards. Bolletino de la Società Paleontologica Italiana, 28 (2/3): 329-339.

Made, J. van der, K. Stefaniak \& A. Marciszak, 2014. The evolution and Polish fossil record of Canis, Alces, Capreolus, Megaloceros, Dama and Cervus. Quaternary International, 326-327: 406-430.

Made, J. van der \& Tong H.W., 2008. Phylogeny of the giant deer with palmate brow tines Megaloceros from west and Sinomegaceros from east Eurasia. Quaternary International, 179: 135-162.

Maldonado Diaz, E., 1996. Revisión de los équidos del Pleistoceno Medio y Superior de España. PhD thesis, Universidad Complutense de Madrid.

Marín, M. 1987. Equus stenonis granatensis en elPleistoceno inferior de Venta Micena (Granada, España). Paelontologia i Evolució, mem. esp. 1: 255-282.

Martin, T., 1987. Artunterschide an den Langkknochen grosser Artiodactyla des Jungpleistozäns Mitteleuropas. Courier Forschungsinsistut Senckenberg, 96: 1-124.

Martínez Navarro, B., 1992. Revisión sistemática de la fauna de macromamíferos del yacimiento de Venta Micena (Orce, Granada, España). In: J. Gibert (ed.) Proyecto Orce-Cueva Victoria (1988-1992), presencia humana en el Pleistoceno Inferior de Granada y Murcia. Museo de Prehistoria J. Gibert, Ayuntamiento de Orce - Orce: 21-85.

Martínez Navarro, B., S. Ros-Montoya, M.P. Espigares \& P. Palmqvist, 2011. Presence of the Asian origin Bovini, Hemibos sp. aff. Hemibos gracilis and Bison sp., at the early Pleistocene site of Venta Micena (Orce, Spain). Quaternary International, 243: 54-60.

Martínez Navarro, B., P. Palmqvist, J. Madurell, S. Ros Montoya, M.P. Espigares, V. Torregrosa, J.A. PérezClaros, 2010. La fauna de grandes mamíeferos de Fuente Nueva-3 y Barranco León-5: estado de la cuestión. In: I. Toro, B. Martínez-Navarro \& J. Agustí (eds.) Ocupaciones humanas en el pleistoceno ingerior y medio de la Cuenca de Guadix-Baza. Arqueología Monografías. Junta de Andalucia, Consejería de cultura: 197-236.

Masini, F., 1989. I Bovini Villafrachiani dell’ Italia. PhD thesis, Universtità consorziate: Modena, Bologna, Firenze, Roma: 1-152, pls. 1-37 , 4 appendices.

Mäuser, M., 1987. Geologische und paläontologische Untersuchungen an der altpleistozänen SäugetierFundstelle Würzburg-Schalksberg. Münchener Geowissenschaftliche Abhandlungen, Reihe Geologie und Paläontologie, 1: 1-78.

Mazo, A.V., 1989. Nuevos restos de Proboscidea (Mammalia) en la cuenca de Guadix-Baza. In: M.T. Alberdi \& F.P. Bonadonna (eds.) Geología y paleontología de la cuenca de Guadix-Baza. trabajos sobre el 
Neogeno-Cuaternario, 11: 225-237.

Mazza, P., 1991. Interralations between Pleistocene hippopotami of Europe and Africa. Bolletino della Società Paleontologica Italiana, 30(2): 153-186.

Mazza, P., B. Sala \& M. Fortelius, 1993. A small latest Villafranchian (Late Early Pleistocene) rhinoceros from Pietrafitta (Perugia, Umbria, central Italy), with notes onthe the Pirro and Westerhoven rhinoceroses. Paleontographia italica, 80: 25-50.

Menéndez, E., 1987. Cérvidos del yacimiento del Pleistoceno inferior de Venta Micena-2, Orce (Granada, España). Paleontología i Evolució, Memoria especial 1: 129-180.

Milli, S. \& M.P. Palombo, 2005. The high-resolution sequence stratigraphy and the mammal fossil record: a test in the Middle-Upper Pleistocene deposits of the Roman Basin (Latium, Italy). Quaternary International, 126-128: 251-270.

Montoya, P., M.T. Alberdi, A.M. Blázquez, L.J. Barbadillo, M.P. Fumaral, J. van der Made, J.M. Marín, A. Molina, J. Morales, X. Murelaga, E. Peñalver, F. Robles, A. Ruiz Bustos, A. Sánchez, B. Sanchiz, D. Soria \& Z. Zsyndlar, 1999. La fauna del Pleistoceno Inferior de la Sierra de Quibas (Abanilla, Murcia). Estudios geológicos, 55(3-4): 129-164.

Montoya, P., M.T. Alberdi, L.J. Barbadillo, J. van der Made, J. Morales, X. Murelaga, E. Peñalver, F. Robles, A. Ruiz Bustos, A. Sánchez, B. Sanchiz, D. Soria, Z. Szyndlar, 2001. Une faune très diversifiée du Pléistocène inférieur de la Sierra de Quibas (province de Murcia, Espange). Comptes Rendus de l'Académie des Sciences, Paris, 332: 387-393.

Moullé, P.É., 1998. Les grands mammifères de la Grotte du Vallonnet. Bulletin du Musée d’Anthropologie Préhistorique de Monaco, 39: 29-36.

Moullé, P.E., A. Echassoux \& B. Martinez-Navarro, 2004. Ammotragus europaeus: une nouvelle espèce de Caprini (Bovidae, Mammalia) du Pléistocène inférieur à la grotte duVallonnet (France). C. R. Palevol, 3: 663-673.

Moullé, P.E., F. Lacombat \& A. Echassoux, 2006. Apport des grands mammifères de la grotte du Vallonnet (Roquebrune-Cap-Martin, Alpes-Maritimes, France) à la connaissance du cadre biochronologique de la seconde moitié du Pléistocène inférieur d’Europe. L’anthropologie, 110: 837-849.

Moyà-Solà, S., 1987. Los bóvidos (Artiodactyla, Mammalia) del yacimiento del Pleistoceno inferior de Venta Micena (Orce, Granada, España). Paelontologia i Evolució, mem. esp. 1: 181-236.

Musil, R. 1969. “Die Equiden-Reste aus dem Pleistozän von Süssenborn bei Weimar”. Paläontologische Abhandlungen, 3(3-4): 617-666.

Musil, R., 1995 a. Large fauna of talus cone at Stránská Skála Hill. In: R. Musil (ed.) Stránská Skála Hill Excavation of open air sediments 1964-1972. Moravian Museum, Litera Foundation - Brno: 65-83.

Musil, R., 1995 b. The Stránská Skála Hill - Its importance and significance. In: R. Musil (ed.) Stránská Skála Hill Excavation of open air sediments 1964-1972. Moravian Museum, Litera Foundation - Brno: 177208.

Musil, R., 2001. Die Equiden-Reste aus dem Unterpleistozän von Untermassfeld. In: Kahlke, R.D. (ed.) Das Pleistozän von Untermassfeld bei Meiningen (Thüringen). Teil 2. Dr Rudolf Habelt GMBH, Bonn: 557-588.

Nikiforofa, K.V., E.I. Beliajeva, E.A. Vangengeim, N.A. Konstantinova, K.N. Negadaev-Nikonov (eds.) 1971. Pleistocene of Tiraspol. Publishing House Shtiintsa - Kisthinev: 1-188.

Orlando, L., M. Mashkour, A. Burke, C.J. Douady, V. Eisenmann \& C. Hähnni, 2006. Geographic distribution of an extinct equid (Equus hydruntinus: Mammalia, Equidae) revealed by morphological and genetical analyses of fossils. Molecular Ecology, 15: 2083-2093.

Orlando, L., J.L. Metcalf, M.T. Alberdi, M. Telles-Antunes, D. Bonjeane, M. Otte, F. Martin, V. Eisenmann, M. Mashkour, F. Morello, J.L. Prado, R. Salas-Gismondi, B.J. Shockey, P.J. Wrinn, S.K. Vasil'ev, N.D. Ovodov, M.I. Cherry, B. Hopwood, D. Male, J.J. Austin, C. Hänni \& A. Cooper, 2009. Revising the recent evolutionary history of equids using ancient DNA. Proceedings of the National Academy of Science, 106(51): 21754-21759.

Ortiz, J.E., Torres, T., Llamas, J.F., Canoira, L., García-Alonso, P., García de la Morena, M.A., Lucini, M., 2000. Dataciones de algunos yacimientos paleontológicos de la cuenca de Guadix-Baza (sector de Cúllar-Baza, Granada, España) y primera estimación de edad de la apertura de la cuenca mediante el método deracemización de amino-acidos. Geogaceta, 28: 109-112.

Parés, J.M., L. Arnold, M. Duval, M. Demuro, A. Pérez-González, J.M. Bermúdez de Castro, E. Carbonell, J.L. Arsuaga, 2013. Reassessing the age of Atapuerca-TD6 (Spain): new paleomagnetic results. Journal of Archaeological Science, 40: 4586-4595.

Parfitt, S.A., N.M. Ashton, S.G. Lewis, R.L. Abel, G. R. Coope, M.H. Field, R. Gale, P.G. Hoare, N.R. Larkin, M.D. Lewis, V. Karloukovski, B.A. Maher, S.M. Peglar, R.C. Preece, J.E. Whittaker \& C.B. Stringer, 
2010. Early Pleistocene human occupation at the edge of the boreal zone in northwest Europe. Nature, 466: 229-233.

Parfitt, S.A., R.W. Barendregt, M. Breda, I. Candy, M.J. Collins, G.R. Coope, P. Durbidge, M.H. Field, J.R. Lee, A.M. Lister, R. Mutch, K.E.H. Penkman, R.C. Preece, J. Rose, C.B. Stringer, R. Symmons, J.E. Whittaker, J.J. Wymer \& A.J. Stuart 2005. The earliest record of human activity in northern Europe. Nature, 438: 1008-1012.

Petronio, C., 1979. Dama nestii eurygonos Azz. di Capena (Roma). Geologica Romana, 18: 105-125.

Pfeiffer, T., 1999. Die Stellung von Dama (Cervidae, Mammalia) im system pleisometacarpaler Hirsche des Pleistozäns. Phylogenetische Reconstruktion - Metrische Analyse. Courier Forschungsinstitut Senckenberg, 211: 1-218.

Pomel, A., 1853. Vertébrés fossiles découvèrts dans le bassin hydrographique supérieur de la Loire, et surtout dans la vallée de son affluent principal l’Allier. J.B. Baillière - Paris: 1-193.

Pomel, A., 1896. Les Hippopotames. Carte géologizue de l’Algérie. Paléontologie Monographies. Imprimerie P. Fontana - Alger: 1-65, pls. 1-21.

Prat, F. 1980. Les équidés Villafranchiens en France Genre Equus. Cahiers du Quaternaire, 2: 1-291.

Qiu Zghanxiang, Deng Tao \& Wang Banyue, 2004. Early Pleistocene mammalian fauna from Longdan, Dongxiang, Gansu, China. Palaeontologica Sinica, 191, new series c, 27: 1-198, pls 1-34.

Ravazzi, C., R. Pinia, M. Breda, E. Martinetto, G. Muttoni, S. Chiesa, F. Confortini \& R. Egli, 2005.The lacustrine deposits of Fornaci di Ranica (late Early Pleistocene, Italian Pre-Alps): stratigraphy, palaeoenvironment and geological evolution. Quaternary International, 131: 35-58.

Rodríguez, J., F. Burjachs, G. Cuenca-Bescós, N. García, J. van der Made, A. Perez-González, H. A. Blain, I. Expósito, J.M. López-García, M. García-Antón, E. Allué, I. Cáceres, R. Huguet, M. Mosquera, A. Ollé, J. Rosell, J.M. Parés, X.P. Rodríguez, J.C. Díez, J. Rofes, R. Sala, P. Saladié, J. Vallverdú, M.L. Bennasar, R. Blasco, E. Carbonell, J.M. Bermúdez de Castro, 2011. One million years of cultural evolution in a stable environment at Atapuerca (Burgos, Spain). Quaternary Science Reviews, 30: 1396-1412.

Roebroeks, W. \& T. van Kolfschoten, 1995. The earliest occupation of Europe: a reappraisal of artefactual and chronololigcal evidence. In: W. Roebroeks \& T. van Kolfschoten (eds.) The earliest occupation of Europe. University of Leiden - Leiden: 297-309.

Rook, L. \& B. Martínez-Navarro, 2010. Villafranchian: The long story of a Plio-Pleistocene European large mammal biochronologic unit. Quaternary International, 219: 134-144.

Rook, L., B. Martínez -Navarro, F.C. Howell, 2004. Occurrence of Theropithecus sp. in the late Villafranchian of southern Italy and implication for Early Pleistocene “out of Africa'” dispersals. Jounral of Human Evolution, 47: 267-277.

Rosell, J., R. Blasco, J. van der Made, I. Cáceres, G. Campeny, J.C. Díez, P. Saladié, E. Carbonell, 2010. Acumulaciones producidas por carnívoros en el Pleistoceno Medio inicial: una reconstrucción a partir del conjunto faunístico del nivel TD8 de Gran Dolina (Sierra de Atapuerca, Burgos). Zona Arqueológica, 13: 158-171.

Sala, B., 1987. Bison schoetensacki Freud. from Isernia la Pineta (early Mid-Pleistocene - italy) and revision of the european species of bison. Palaeontograpchia Italica, 74: 113-170.

Sala, B., 1996. Gli animali del giacimento di Isenia La Pineta. In: C. Peretto (ed.) I reperti paleontolgogici del giacimento paleolitico di Isernia La Pineta. L’Uomo e l'ambiente. Cosmo Iannone Editore - Isernia: 2586.

Sardella, R.; L. Caloi; G. Di Stefano; M.R. Palombo; C. Petronio; L. Abbazzi; A. Azzaroli; G. Ficcarelli; P. Mazza; C. Mezzabotta; P. Argenti; L. Capasso Barbato; T. Kotsakis; E. Gliozzi; F. Masini \& B. Sala, 1998. Mammal faunal turnover in Italy from the Middle Pliocene to the Holocene. Mededelingen Nederlands Instituut voor Toegepaste Geowetenschappen TNO, 60: 499-519.

Sardella, R. \& M. Petrucci, 2012. The earliest Middle Pleistocene Crocuta crocuta (Erxleben, 1777) at Casal Selce(Rome, Italy). Quaternary International, 267: 103-110.

Schaub, S., 1951. Soergelia n. gen., ein Caprine aus dem thüringischen Altpleistocän. Eclogae geologicae Helvetiae, 44(2): 375-381.

Schreiber, H.D., 2005. Osteological investigations on skeleton material of Rhinoceroses (Rhinocerotidae, Mammalia) from the early Middle Pleistocene locality of Mauer near Heidelberg (SW-Germany). Quaternaire, Hors-série 2: 103-111.

Scott, G.R. \& L. Gibert, 2009. The oldest hand-axes in Europe. Nature, 461: 82-85.

Sesé, C. \& E. Soto, 2000. Vertebrados del Pleistoceno de Madrid. In: J. Moraels (ed.) Patrimonio Paleontológico de la Comindad de Madrid. Arqueología Paelontología y Etnografía, 6: 216-243.

Shackleton, N., 1995. New data on the evolution of Pliocene climatic variability. In E.S. Vrba, G.H. Denton, 
T.C. Partridge \& L.H. Buckle (eds.). Palaeoclimate and evolution with emphasis on human evolution. Yale University Press, New Haven and London: 242-248.

Shchelinsky,V.E., A.E. Dodonov, V.S. Baigusheva, S.A. Kulakov, A.N. Simakova, A.S. Tesakov \& V.V. Titov, 2010. Early Palaeolithic sites on the Taman Peninsula (Southern Azov Sea region, Russia): Bogatyri/Sinyaya Balka and Rodniki. Quaternary International, 223-224: 28-35.

Sher, A., 1992. Beringian fauna and early Quaternary mammalian dispersal in Eurasia: ecological aspects. Courier Forschuntsinstitut Senckenberg, 153: 125-133.

Sher, A.V. 1997. An Early Quaternary bison population from Untermassfeld: Bison menneri sp. nov. In: R. D. Kahlke (ed.) Das Pleistozän von Untermassfeld bei Meiningen (Thüringen). Bonn, Dr Rudolf Habelt GMBH: 101-180.

Sickenberg, O., 1962. Úber die Grösse der pleistozänen Pferde der Caballus-Gruppe in Europa und Nordasien. Eiszeitalter und Gegenwart, 12: 99-124.

Siori, M.S., A. Boero, G. Carnevale, S. Colombero, M. Delfino, R. Sardella \& M. Pavia, 2014. New data on Early Pleistocene vertebrates from Monte Argentario (Central Italy). Paleoecological and biochronological implications. Geobios, 47: 403-418.

Soto, E., 1987. Grandes herbívoros del Pleistoceno Medio de la Trinchera de Ferrocarril de Atapuerca (Burgos, España). In: E. Aguirre, E. Carbonell \& J.M. Bermúdez de Castro (eds.) El hombre fósil de Ibeas y el Pleistoceno de la Sierra de Atapuerca I. Junta de Castilla y León. Consejería de Cultura y Bienestar Social: 93-116.

Soto, E. \& J. Morales, 1985. Grandes mamíefros del yacimiento Villafranquiense de Casablanca 1, Almenara (Castellón). Estudios geológicos, 41: 243-249.

Spaan, A., 1992. A revision of the deer from Tegelen (province of Limburg, The Netherlands). Scripta Geologica, 98: 1-85.

Steensma, K.J., 1988. Plio-/Pleistozäne Grosssäugetiere (Mammalia) aus dem Becken von Kastoria/Grevena, südlich von Neapolis - NW-Griechenland. PhD thesis. Mathematisch-Naturwissenschaftlichen Fakultät der TechnischenUniversität Clausthal: 1-315.

Stuart, A.J., 1982. Pleistocene vertebrates in the British Isles. Longman - London \& New York: 1-212.

Stuart, A.J. \& A.M. Lister, 2001. The mammalian faunas of Pakefield/Kessingland and Corton, Suffolk, UK: evidence for a new temperate episode in the British early Middle Pleistocene. Quaternary Science Reviews, 20: 1677-1692.

Thenius, E., 1965. Die Carnivoren-Reste aus dem Altpleistozän von Voigtstedt bei Sangerhausen in Thüringen. Paläontolgosche Abhlungen Abeilu A Paläozoologi, 2/2-3: 537-564 .

Toro, I., B. Martínez-Navarro \& J. Agustí (eds.), 2010. Ocupaciones humanas en el pleistoceno inferior y medio de la Cuenca de Guadix-Baza. Arqueología Monografías. Junta de Andalucia, Consejería de cultura: 1582.

Toro-Moyano, I., B. Martínez-Navarro, J. Agustí, C. Souday, J.M. Bermúdez de Castro, M. Martinón-Torres, B. Fajardo, M. Duval, C. Falguères, O. Oms, J.M. Parés, P. Anadón, R. Julià, J.M. García-Aguilar, A.M. Moigne, M.P. Espigares, S. Ros-Montoya \& P. Palmqvist, 2013. The oldest human fossil in Europe, from Orce (Spain). Journal of Human Evolution, 65: 1-9.

Tsoukala, E.S.,1989. Contribution to the study of the Pleisocene fauna of large mammals (Carnivora, Perissodactyla, Artiodactyla) from Petralona Cave, Chalkidiki (N. Greece). PhD thesis. Aristotle Univestiy of Thessaloniki, School of Geology - Scientific Annals, 1(8): 1-360, pls. 1-62.

Vangengeim, E.A., M.V. Sotnikova, L.I. Alekseeva, I.A. Vislobokova, V.I. Zhegallo, S. Zazhigin, \& N.S. Shevyreva, 1988. Late Pliocene - Early Pleistocene biostratigraphy of Tadzhikistan. Moscow - Nauka: $1-126$.

Vekua, A., 1986. The Lower Pleistocene Mammalian Fauna of Akhalkali (Southern Georgia, USSR). Palaeongographia Italica, 74: 63-96.

Vekua, A.K., 1995. Die Wirbeltierfauna des Villafranchiums von Dmanisi und ihre biostratigraphische Bedeutung. Jahrbuch des Römisch-Germanischen Zentralmuseums, 42: 77-180.

Vislobokova, I.A., 1990. The fossil deer of Eurasia. (In Russian.) Trudy Paleonto logicheskii Institute Akademia Nauka SSSR, 240: 1-208.

Vislobokova, I.A., 2012: Giant Deer: Origin, Evolution, Role in the Biosphere. Paleontological Journal, 46(7): 643-775.

Wagner, G.A., M. Krbetschek, D. Degering, J.J. Bahain, Q. Shao, C. Falguères, P. Voinchet, J.M. Dolo, T. Garcia \& G.P. Rightmire, 2010. Radiometric dating of the type-site for Homo heidelbergensis at Mauer, Germany. Proceedings of the National Academy of Sciences, 107(46), 19726-19730.

Wagner, J., S. Cermák \& I. Horácek, 2011. The presence of Ursus ex gr. minimus-thibetanusin the late Villányian and its position among the Pliocene and Pleistocene black bears in Europe. Quaternaire, 
Hors-série 4: 39-58.

Wagner, J. \& M. Gasparik, 2015. Research history of Pleistocene faunas in Gombasek quarry (Slovakia), with comments to the type specimen and the type locality of Ursus deningeri gombaszogensis Kretzoi, 1938. Fragmenta Palaeontologica Hungarica, 31: 125-143.

Walker, M.J., Rodríguez Estrella, T., Carrión García, J.S., Mancheño Jiménez, M.A., Schwenninger, J.-L., López Martínez, M., López Jiménez, A., San Nicolás del Toro, M., Hills, M.D.,Walkling, T., 2006. Cueva Negra del Estrecho del Río Quípar (Murcia, Southeast Spain): an Acheulian and Levalloiso-Mousteroid assemblage of Palaeolithic artifacts excavated in a Middle Pleistocene faunal context with hominin skeletal remains. Eurasian Prehistory, 4(1-2): 3-43.

Wiegank, F., 1997. Paläomagnetische charakteristik des Unterpleistozäns von Untermassfeld. In: R. D. Kahlke (ed.) Das Pleistozän von Untermassfeld bei Meiningen (Thüringen). Dr Rudolf Habelt GMBH, Bonn: 63-69.

Xue Xiangxi \& Zhang Yunxiang, 1991.The Quaternary mammalian fossils and the fossil human beings in China. In: Zhang Zonghu \& Shao Shixiong (eds.) The Quaternary of China. Cina Ocean Press - Beijing: 307374.

\section{Figure 1}

Schematic section of Gran Dolina and photograph of TD8 and the top of TD7, indicating the approximate level of the Brunhes Matuyama Boundary.

\section{Figure 2}

Lithostratigraphic section of Gran Dolina with amplification of TD6-8 to show the Brunhes-Matuyama boundary and normal events within TD7, as well as the IRSL, TL and ESR and U-sieres dates. After Berger et al. (2008) and Parés et al. (2013).

\section{Figure 3}

Equus altidens from Atapuerca TD8: 1) Ata03, TD8B, H3, 1 - right $\mathrm{P}^{3 / 4}$ : a) buccal, and b) occlusal views. 2) Ata03, TD8B, G-6, 18 - left $\mathrm{M}_{2}$ : a) lingual, and b) occlusal views. Ata03, TD8B, G-6, 17 - left $\mathrm{M}_{1}$ : a) lingual, and b) occlusal views.

Diagrams showing the occlusal length (DAPo) and protoconal index (PI) of the $\mathrm{M}^{1 / 2}$ and $\mathrm{P}^{3 / 4}$ of Equus altidens from Atapuerca TD8 compared to selected samples and species of Equus. Provenance of data: $E$. caballus, E. przewalskii, E. mosbachensis, E. kiang, E. hemionus, E. stenonis senezensis, E. stenonis vireti, E. stenonis cf. vireti (all from Eisenmann, 1979), E. germanicus and E. hydruntinus from Villa Seckendorff (Forsten \& Ziegler, 1995), E. hydruntinus binagadiensis from Binagady (Eisenmann \& Kuznetsova, 2004), E. petraloniensis from Petralona (Tsoukala, 1989), E. wuesti from Untermassfeld (Musil, 2001), Equus altidens from Venta Micena (Marín, 1987; also the larger sample measured near the crown base is included), Equus sp. from Libakos (Steensma, 1988), Ubeidiya (Eisenmann, 1986), and Equus sp. from Láchar (Alberdi \& RuizBustos, 1987).

\section{Figure 4}

The third metacarpal (Mc III) of Equus altidens from Atapuerca TD 8: Ata2002, TD8B, G-10, 35 - right third metacarpal from TD8: 1a) proximal, and 1b) anterior views.

Bivariate diagrams of the distal articular width (DTdf) and length (L) of the third metacarpal comparing a specimen from Atapuerca TD8 to those of selected Equidae. The upper diagram shows the presence of two well defined groups with robust and gracile metapodials. Provenance of data: robust caballoid Equus from Villa Seckendorff (Forsten \& Ziegler, 1995), Solutré (Prat, 1980), and Mosbach and E. przewalskii (Eisenmann, 1979); gracile E. wuesti from Untermassfeld (Musil, 2001), E. nalakhensis from Nalaikha (Eisenmann \& Kuznetsova, 2004), E. altidens from Venta Micena (Marín, 1987) and Süssenborn (isolated specimen; Musil, 1969), E. petraloniensis from Petralona (Tsoukala, 1989), E. minor from Lunel Viel (LV) and E. hydruntinus from Lunel Viel and Binagady (isolated specimens) (both Eisenmann \& Mashkour 1999); and the intermediate E. suessenbornensis from Süssenborn (Musil, 1969), Ceyssaguet (Prat, 1980), Nalaikha (Eisenmann \& Kuznetsova 2004) and Semibalki (AHAPMR).

The lower diagram shows a series of samples that show a transition from robust to gracile: E. stenonis vireti from Saint Vallier and E. s. cf. vireti from La Puebla de Valverde (Eisenmann, 1979), Equus sp. from Ubeidiya (Eisenmann, 1986), Pirro Nord and Selvella (Alberdi \& Palombo, 2013), and Libakos (TUC), and E. altidens from Venta Micena (Marín, 1987).

\section{Figure 5}


The robusticity (100 L/DTdf; average values only) and distal width of the articular surface (DTdf; average and range) of the third metacarpal (Mc III) in the smaller stenonid horses. Provenance of data as in the previous figure and, in addition, from Forsten (1999) and Steensma (1988). The chronologic distribution of the European Pleistocene Equidae; systematics largely after Forsten (1999).

\section{Figure 6}

The right first phalanx (III-1) of Equus altidens from Atapuerca TD8 - Ata94, TD8, t31, I-16, 65: 1a) dorsal, and 1b) proximal views.

Bivariate diagrams of the distal articular width (DTdf) and length (L) of the third metacarpal comparing a specimen from Atapuerca TD8 to those of selected Equidae. The difference between robust and gracile equids is also noted, though not as clear as in the Mc.

Provenance of data: robust caballoid Equus from Saint-Germain-la-Riviere (Prat, 1980), gracile E. wuesti from Untermassfeld (Musil, 2001), E. nalakhensis from Nalaikha (Eisenmann \& Kuznetsova, 2004$),$ E. altidens from Venta Micena (Marín, 1987), E. petraloniensis from Petralona (Tsoukala, 1989), E. hydruntinus from Lunel Viel (Eisenmann \& Mashkour 1999) and Arenero Santa Catalina (Madrid; MAN) and the intermediate E. suessenbornensis from Süssenborn (Musil, 1969), Soleilhac (Prat, 1980) and Tiraspol (Gromova \& Dubrovo 1975).

\section{Figure 7}

Stephanorhinus aff. etruscus from Atapuerca TD8: 1) Ata2002, TD8B, F-12, 50 - $\mathrm{D}_{3}$ dext.: a) lingual, b) occlusal, and c) buccal views. 2) Ata94, TD8, t28, I-16, 16 - Phalanx III-1 sin.: a) lateral, and b) dorsal views. 3) Ata94, TD8, t29, I-16, 35 - $\mathrm{P}^{2}$ sin.: buccal view.

The chronologic distribution of the European Pleistocene Rhinocerotidae (after Van der Made \& Grube, 2010). Conventions as in Figure 3; Coelodonta is present mainly in glacials and S. kirchbergensis only in interglacials, these are not "dashed lines" but indicate discontinuous presence in Europe.

Bivariate diagram of the proximal width (DTp) against length (L) of the first phalanx comparing the Stephanorhinus from TD8 to Stephanorhinus aff. etruscus from Atapuerca TD7/2 (IPHES), S. etruscus from the Upper Valdarno (IGF); S. hundsheimensis from Untermassfeld (IQW) and Mauer (SMNK); and from Hundsheim (NMW); S. hemitoechus from Arago (LPTUP), Bilzinglseben (FBFSUJ), Atapuerca TD10 (IPHES), and Azokh 1-V (MUB); S. kirchbergensis from Bilzingsleben (FBFSUJ).

Bivariate diagram of the proximal width (DTp) against length (L) of the first phalanx comparing the Stephanorhinus from TD8 to Stephanorhinus aff. etruscus from Libakos (TUC), Huéscar 1 (MNCN), Atapuerca TDW4 (MB), and Cueva Victoria (MAC); S. etruscus from the Upper Valdarno (IGF); S. hundsheimensis from Vallonnet (MPRM), Dorn Dürkheim (FISF), Voigtstedt (IQW), Süssenborn (IQW), Mosbach (NMM), Soleilhac (MCP), Mauer (SMNK), Mosbach (NMM), and from Hundsheim (NMW); S. hemitoechus from Bilzingsleben (FBFSUJ), Murr (SMNS), Ehringsdorf (IQW), and the Rheinebene (NMM); S. kirchbergensis from Bilzingsleben (FBFSUJ), Ehringsdorf (IQW), Neumark Nord (FBFSUJ), and Gimbsheim (Rheinebene; NMM).

\section{Figure 8}

The Suiformes from Atapuerca TD8: 1) Ata94, TD8, t29, I-16, 62 - right I² of Hippopotamus sp. from TD8: a) mesial, b) lingual, and c) labial views. 2) Ata2002, TD8b, G-7, 32 - right second central phalanx (phalanx III/IV2) of Hippopotamus sp. from TD8: a) distal, b) dorsal, c) abaxial, d) plantar, and e) proximal views. Sus scrofa from TD8: Ata06, TD8B, G-4, 145 - left $\mathrm{M}^{1}$ occlusal view (photograph).

The chronologic distribution of the Pleistocene European species of Sus and Hippopotamus.

Conventions as in Figure 7; in addition: localities according to their approximate age, the presence of a species in a locality is indicated with a solid square, while tentative or possible (cf., aff., sp., ?) presence is indicated with an open square.

Bivariate diagram of the width of the anterior lobe (DTa) against length (DAP):

Sus strozzii from: Gerakarou (AUT), Senèze (UCBL), Tegelen (NBC, MNB), Olivola (IGF), Valdarno (IGF, AVP), Il Tasso (IGF); and Sus scrofa from: Atapuerca TD8 \& TD10 (IPHES), Koneprusy (PIMUZ, cast), Mosbach (NMM), Mauer (SMNK), Trimingham (NHM), Megalopolis (AUT), Taubach (IQW), Pinilla del Valle (UCM), Kafzeh (IPH), Can Rubau (CIAG), Sakazia (GSM), Cueva de Saldarañao (ETSI), Német Bogsan (HGSB), and recent Sus scrofa from Spain, the Netherlands and Germany (MNCN, ZMA, NBC, DGFSUPV).

\section{Figure 9}

The second phalanx of the larger ruminants from Atapuerca TD8: 1) Ata06, TD8b, G-3, 71 - left second phalanx of Megaceroides solilhacus: a) plantar, and b) abaxial views. 2) ATA06, TD8b, G-4, 38 - left second phalanx of Bison voigtstedtensis: a) distal, b) plantar, c) proximal, d) axial, e) dorsal, and f) abaxial views. 3) Ata05, TD8b, 
F-13, 2 - right second phalanx of Cervus elaphus: a) plantar, b) axial, c) dorsal, d) abaxial, e) distal, and f) proximal views.

Bivariate diagrams comparing the length (L), proximal width (DTp), distal antero-posterior diameter (DAPd) and distal width (DTd) of the second phalanx of Cervus, Megaceroides and Bison from Atapuerca TD8 to: Cervus elaphus from Azokh V \& VI (MUB) and Neumark Nord (FBFSUJ); Bos primigenius from Miesenheim (Monrepos), Torralba (MNCN), Neumark Nord (FBFSUJ), and Lehringen (HMV); Bison menneri from Untermassfeld (IQW); Bison schoetensacki from Akhalkalaki (IQW), Apollonia 2 (AUT), Konéprusy (NMP), Süssenborn (IQW), West Runton (NHM), Soleilhac (MCP), Blanzac-Soleilhac (NMB), Tsona (GSM), Mauer (SMNK), Bacton (NHM), Mundesley (NHM), Vérteszölös (HGSB), Bilzingsleben (FBFSUJ), and Azokh V (MUB); Bison priscus from Unkelstein (IPRFWUB) and Ortvala Klde (GSM); Eucladoceros giulii and E. aff. giulii from Untermassfeld (IQW) and Akhalkalaki (GSM); Megaceroides from Ubeidiya (HUJ), Cesi (IGF), Voigtstedt (IQW), Süssenborn (IQW), and Soleilhac (MCP); and small Eucladoceros from Tegelen (NBC), Olivola (IGF), and Il Tasso (IGF).

\section{Figure 10}

Giant deer from Atapuerca TD8 and other localities: 1) Ata2002, TD8b, G-12, 26 - right $\mathrm{M}_{3}$ of Eucladoceros aff. giulii from TD8: a) lingual, b) occlusal, and c) buccal views. 2) Ata2002, TD8b, G-12, 10 - Left $\mathrm{P}^{4}$ of ?Eucladoceros aff. giulii from TD8: a) posterior, , b) occlusal, and c) buccal views. 3) Eucladoceros tetraceros from Peyrolles: NHM 34409 left shed antler, lectotype, medial view. 4) Eucladoceros aff. giulii from Atapuerca Gran Dolina: ATA90, TD4 left shed antler, lateral view. 5) Eucladoceros giulii from Untermassfeld: reconstruction after H.D. Kahlke (1997). 6) Megaceroides boldrinii from Aliakmon, NCUA no number, oblique right-anterior view. 7) Megaceroides solilhacus from Soleilhac: MCP no number, left antler, medial view. 8) Megaloceros savini from Süssenborn: IQW 1964/1937, Süss 7075 skull fragment with left antler oblique lateral/inferior view. 9) Megaloceros giganteus from Steinheim: SMNS 15795 skull with antlers (oblique frontal view). The teeth are to scale, the antlers not.

The temporal distribution of the giant deer of the European main land. Conventions as in Figure 5. Bivariate diagrams comparing width of the anterior (DTa) and posterior (DTp) lobes of the $\mathrm{M}_{3}$ of the giant deer from TD8 to: Megaloceros sp. from Libakos (TUC), Cueva Victoria (MAC), and localities in the Madrid area (MSI, MAN, MNCN), Megaloceros savini from Voigtstedt (IQW), Süssenborn (IQW) and Mundesley (NHM); Megaloceros giganteus from Ireland (NHM) and the Rheinschotter (NMM); Megaceroides from Tiraspol (GIN), Voigtstedt (IQW, SMS), Süssenborn (IQW), Soleilhac (MCP), West Runton (NHM), and Mosbach (NMM); Eucladoceros giulii from Untermassfeld (IQW); and Eucladoceros aff. giulii from Akhalkalaki (GSM), Apollonia 1 (AUT), and Lakhuti II (PIN).

\section{Figure 11}

The first and third phalanx of the larger ruminants from Atapuerca TD8: 1) Ata06, TD8b, G-04, 113 - left first phalanx of Megaceroides: a) plantar, b) abaxial, c) dorsal, d) axial, e) distal, and f) proximal views; 2) right first phalanx of Bison: a) distal, b) axial, c) dorsal, d) abaxial, e) plantar, and f) proximal views; 3) Ata04, TD8b, F14, 10 - right first phalanx of Megaceroides, proximal view; Ata06, TD8b, G-4, 41 - left third phalanx of Bison, proximal view.

Bivariate diagrams comparing the length (L) and proximal width (DTp) of the first phalanges from Atapuerca TD8 with: Cervus elaphus from Neumark Nord (FBFSUJ); Eucladoceros tegulensis from Tegelen (NMMaa) and E. dicranios from Il Tasso (IGF); Eucladoceros giulii from Untermassfeld (H.D. Kahlke, 1997), Eucladoceros aff. giulii from Atapuerca TD4 and TD7 (MB, IPHES) and Apollonia 1 (AUT); Megaceroides boldrinii from Ubeidiya (HUJ); Megaceroides solilhacus from Voigtstedt (IQW), Süssenborn (IQW), Soleilhac (MCP) and West Runton (NHM); Bison menneri from Untermassfeld (Sher, 1997), Bison degiulii from Pirro Nord (IGF); Bison schoetensacki from Akhalkalaki (GSM), Apollonia 1 (AUT), Süssenborn (IQW), Soleilhac (MCP), Mauer (SMNK), Vérteszölös (HGSB), and Bilzingsleben (FBFSUJ); Bison priscus from Unkelstein (IPRFWUB); and Bos primigenius from Miesenheim (Monrepos), Neumark Nord (FBFSUJ), Lehringen (HMV), and Can Rubau (CIAG).

\section{Figure 12}

The right lower cheek teeth of Megaceroides solilhacus from Atapuerca TD8 (Ata2002, TD8b, G-7, 93): a) lingual, b) occlusal, and c) buccal views.

\section{Figure 13}

The antlers of the Dama-like deer. 1) Ata03, TD8b, G-5, 44 - the basal part of a left shed antler of Dama vallonnetensis from Atapuerca TD8. 2) IGF363 - skull fragment with two antlers of Dama nestii, type from the 
upper Valdarno: frontal view. 3) NBC St28148 - left antler of Dama rhenana from Tegelen: lateral view. 4) Reconstruction of Dama from Atapuerca TE9 by Eduardo Saíz. 5) NCM 2004.831.13/14 - skull fragment with both antlers, holotype of Dama robertorum, from Pakefield: oblique left view. 6) MCP Sol 2003-4-390 right antler of Dama from Soleilhac: lateral view. 7) FBFSUJ 27/6/89-13 - right antler and skull fragment of Dama dama geiselana from Neumark Nord: medial view. Figures 2-7 not to scale. The temporal distributions of the different west European species of Dama-like deer, indicated as thick lines, dashed in the case of tentative distributions. The scale applies to photograph 1; other photographs not to scale.

The position of the bifurcation of brow tine and main beam above the burr, indicated as the index 100 Hext / DAPb in the following samples: Montopoli (IGF), Tegelen (NBC, NMMa, TMH), Senèze (IQW), Olivola (IGF), Matassino (IGF), Upper Valdarno (IGF), Dmanisi (GSM), Láchar (MNCN), Mundesley (NHM), East Runton (NHM), Cava Liberatori (IGF), Selvella (IGF), Val di Chiana (IGF), Casa Palazzi (IGF), Cava dell'Erba (IGF), Capena (DSTUSR), Libakos (TUC), Venta Micena (IPS), Atapuerca TE7, TDW3-4, TDE5, TD6, TZ, TG11, TD10 (MB, CENIEH, IPHES), Taman (PIN), Untermassfeld (IQW), Vallonnet (MPRM), El Chaparral (MHMV), Gesher Benot Ya’akov (HUJ), Cueva Victoria (MAC), Ponte Galeria (DSTUSR), Tiraspol (GIN), West Runton (NHM), Bacton (NHM), Soleilhac (MCP), Mosbach (IQW), Arago (LPTUP), Bilzingsleben (FBFSUJ), Petralona (AUT), Clacton (NHM), Swanscombe (NHM), Neumark Nord (FBFSUJ, now in LVH), Gimbsheim (NMM), Lehringen (HMV), Pinilla del Valle (UCM, presently MAR), recent Dama dama from the Doñana national park (EBD).

\section{Figure 14}

The dentition of Dama vallonnetensis from Atapuerca TD8. 1) Ata06, TD8b, G3, 62 - right mandible with $\mathrm{P}_{2}-$ $\mathrm{M}_{3}$ : a) lingual, b) occlusal, and c) buccal views. 2) Ata06, TD8b, G4, 126 - left mandible with $\mathrm{P}_{2}-\mathrm{M}_{3}$ : a) buccal, b) occlusal, and c) lingual views. 3) Ata02, TD8b, G10, 26 - left $\mathrm{M}_{2}$ : a) lingual, b) occlusal, and c) buccal views. 4) Ata02, TD8b, G11, 14 - left $\mathrm{M}_{2-3}$ : a) buccal, b) occlusal, and c) lingual views. 5) Ata02, TD8b, G8, 44 - left $\mathrm{P}_{4}$ : a) lingual, b) occlusal, and c) buccal views. 6) Ata02, TD8b, G7, 12 - right $\mathrm{M}^{3}$ : a) buccal, and b) occlusal views. 7) Ata05, TD8b, H3, 33 - right $\mathrm{P}_{3-4}$ : a) lingual, and b) occlusal views. 8) Ata02, TD8b, G8, 16 - left $\mathrm{P}_{3}$ : a) lingual, b) occlusal, and c) buccal views. 9) Ata02, TD8b, G13, 18 - right $\mathrm{M}^{3}$ : a) occlusal, b) buccal, and c) anterior views. Upper scale: figure 1; left lower scale: figures 3, 5 \& 8; right lower scale: figures 2, 4, 6,7 \& 9 .

\section{Figure 15}

The $\mathrm{M}_{3}$ of Dama vallonnetensis: 1) Ata05-TD8b-F13-15 - right $\mathrm{M}_{3}$, occlusal view; 2) Ata05-TD8b-F13-17 right $\mathrm{M}_{3}$, occlusal view. Schematic representation of different morphologies of the third lobe of the $\mathrm{M}_{3}$, occlusal view: 3-7.

The width of the first lobe (DTa) of the M3 of the Dama-like deer, as indicative of general size from: Montopoli (IGF), Olivola (IGF), Tegelen (NNML, TMH, NMMaa), Casablanca 1 (SIAP), Solava (IGF), Upper Valdarno (incl. Il Tasso \& Casa Frata; IGF), Pyrgos (IVAU, presently NCUA), Selvella (IGF), Cava dell’Erba (IGF), Zabia Cave (ZPALUWr), Libakos (TUC), Venta Micena (Menéndez, 1987), Atapuerca TE7 \& TE9 (CENIEH, IPHES), Vallonnet (MPRM), Untermassfeld (IQW), Atapuerca TD4+5, TD6 \& TD8 (CENIEH, MB, IPHES), Cueva Victoria (MAC), Süssenborn (IQW), West Runton (NHM), Cesi (IGF), Mosbach (NMM), Arago (LPTUP), Atapuerca TD10 \& TG10-11 (MB, IPHES), Petralona (AUT), Bilzingsleben (FSBFSUJ), Swanscombe (NHM), Orgnac 3 (LPTUP), Murr (SMNS), Neumark Nord (FSBFSUJ, presently LVH), Gimbsheim (NMM), Pinilla del Valle (UCM, presently MAR), Can Rubau (CIAG), Taglar (MUB), Dahne (MNB), Spain recent (MNCN).

\section{Figure 16}

The metacarpal and first phalanx of Dama vallonnetensis from Atapuerca TD8: 1) Ata02, TD8b, G-8, 55+39 left metacarpal, anterior view. 2) Ata03, TD8b, G-15, 6 - first phalanx, right of the axis of the foot, a) plantar, b) axial, c) dorsal, d) abaxial, e) proximal, and f) distal views.

Bivariate diagram comparing the distal width (DTdf) and length (L) of the metacarpals of Dama vallonnetensis from Atapuerca TD8 to those of Dama rhenana rhenana from Tegelen (NMMaa, NBC) and Montopoli (IGF); Dama rhenana philisi from Senèze (Heintz, 1970) and Fonelas (Garrido, 2008a); Dama vallonnetensis from Untermassfeld (H.D. Kahlke, 1997);Dama robertorum? from Isernia la Pineta and Valdemino (Breda et al., 2015) and from Overstrand and Trimingham (Azzaroli, 1953); Dama from Venta Micena (Menéndez, 1987); Dama from Capena (Petronio, 1979); Dama valliensis from Saint Vallier (Heintz, 1970); Dama nestii nestii from the Upper Valdarno (IGF) and Dmanisi (GSM); Dama nestii farnetensis from Selvella (Azzaroli, 1992); and Dama clactoniana from Clacton, Swanscombe and Jaywick (all Leonardi and Petronio, 1976). As an indication for the expected variability of a population, a diagram is given with the large sample of Dama dama geiselana from Neumark Nord (Halle). 
Bivariate diagram comparing the proximal width (DTp) and length (L) of the first phalanges of Dama rhenana from Tegelen (NBC, NMMaa); Dama nestii from the Upper Valdarno (IGF); Dama vallonnetensis from Untermassfeld (H.D. Kahlke, 1997); Dama dama geiselana from Neumark Nord (Halle).

\section{Figure 17}

Bison voigtstedtensis from Atapuerca TD8: 1) Ata02, TD8b, G7, 90 - right $\mathrm{M}^{3}$ : a) buccal, b) occlusal view; 2) Ata02, TD8b, G8, 21 - right $\mathrm{M}^{2}$ : a) buccal, b) occlusal view; 3) Ata02, TD8b, G12, 26 - right $\mathrm{M}_{3}$ : a) lingual, b) occlusal, c) buccal view.

The temporal distribution of the European bisons. Conventions as in Figure 3.

Bivariate diagram of the width of the anterior (DTa) and posterior lobe (DTp) of the $\mathrm{M}_{3}$, comparing Bison voigtstedtensis from Atapuerca TD8 with: B. menneri from Untermassfeld (IQW); B. voigtstedtensis from Voigtstedt (IQW); B. voigtstedtensis? from Süssenborn (IQW), B. degiulii from Pirro Nord (IGF); B. schoetensacki lagenocornis from Süssenborn (IQW); B. schoetensacki from Mauer (SMNK).

\section{Figure 18}

The fauna from Atapuerca TD8 in the context of faunal change around the Early Middle Pleistocene transition. From left to right: age in millions of years (Ma), paleomagnetism, isotope stages, the localities in their tentative chronologic positions, the fauna. Thick lines indicate assumed temporal distribution, dashed lines indicate uncertainty, oblique lines connecting vertical lines indicate tentative ancestor-descendant relationships. Solid squares indicate presence of a taxon in a locality, open squares indicate tentative or possible presence of a taxon (usually indicated as: cf., aff., ?, sp.). 
Table 1

Measurements (in $\mathrm{mm}$ ) of the upper and lower decidual and permanent cheek teeth of Equus altidens from Atapuerca TD8 (in mm and taken according to Eisenmann et al., 1988; but width of the lower teeth taken at the anterior and posterior lobes; measurements: occlusal/half estimated height).

\begin{tabular}{|c|c|c|c|c|c|c|c|c|}
\hline number & & & $\mathbf{H}$ & DAP & DT & protocone & $\mathbf{P}$ index & plis \\
\hline Ata94, TD8, t28, G17, 12 & $\mathrm{D}^{2}$ & $\mathrm{~s}$ & $>12.0$ & 40.6/-- & 22.7/-- & 6.0/-- & & ?-?-2-?/? \\
\hline Ata94, TD8, t28, H16, 14 & $D^{2}$ & $\mathrm{~s}$ & $>28.5$ & $36.8 / 37.1$ & 25.3/-- & $6.4 / 7.9$ & & \\
\hline Ata2002, TD8B, F-12, 49 & $D^{2}$ & $\mathrm{~s}$ & 25.3 & $44.1 / 42.8$ & $17.6 / 22.3$ & $6.5 / .$. & & \\
\hline Ata2002, TD8B, G11, 8 & $D^{x}$ & .. & -- & -- & -- & -- & -- & -- \\
\hline Ata94, TD8, t28, H16, 34 & $D^{3 / 4}$ & $d$ & $>30.6$ & $35.9 / 34.2$ & $21.8 / 24.3$ & $10.6 / 10.5$ & & \\
\hline Ata2002, TD8B, G13, 10 & $D^{3 / 4}$ & $\mathrm{~s}$ & $\approx 30$ & $33.9 / 31.9$ & 21.9/-- & $10.2 / .$. & & unworn \\
\hline Ata06, TD8B, G4, 93 & $D^{3 / 4}$ & $\mathrm{~s}$ & -- & $33.9 / \approx 31.7$ & 19.4/-- & $11.9 / 10.4$ & & \\
\hline Ata94, Td8, t2, G17, 13 & $\mathrm{P}^{2}$ & $d$ & $>37.7$ & $36.5 / 36.7$ & $25.4 / 25.6$ & $\approx 8.7 / .$. & & \\
\hline Ata94, TD8, t28, G17, 10 & $\mathrm{P}^{3 / 4}$ & $\mathrm{~s}$ & 71.4 & $31.2 / 26.7$ & $22.8 / 26.2$ & $12.9 / 10.6$ & $41 / 40$ & \\
\hline Ata03, TD8B, H3, 1 & $\mathrm{P}^{3 / 4}$ & $d$ & $>68.4$ & $26.6 / 26.7$ & $25.8 / 27.6$ & $10.5 / 11.9$ & $39 / 45$ & $1-6-6-1 / 1$ \\
\hline Ata94, TD8, t28, G16, 44 & $\mathrm{M}^{1 / 2}$ & $\mathrm{~s}$ & $>49.7$ & $26.0 / 26.6$ & $26.1 / 26.5$ & $9.2 / 9.0$ & $35 / 34$ & $1-1-1-1 / 0$ \\
\hline number & & & $\mathbf{H}$ & DAP & DTa & DTp & fossid $1 / 2$ & buckle \\
\hline Ata2002, TD8B, G-7, 3 & $\begin{array}{l}D_{3} \\
D_{4}\end{array}$ & $d$ & & $\begin{array}{l}35.1 / 34.3 \\
38.6 / 37.2\end{array}$ & $\begin{array}{l}9.9 / 14.4 \\
8.5 / 13.7\end{array}$ & $\begin{array}{l}10.8 / 13.7 \\
9.6 / 12.8\end{array}$ & $\begin{array}{l}10.5 / \approx 11.2 \\
9.8 / \approx 12.3\end{array}$ & $\begin{array}{l}13.0 / 19.8 \\
15.1 / 19.6\end{array}$ \\
\hline Ata03, TD8B, G-5, 29 & $\mathrm{P}_{3 / 4}$ & $\mathrm{~s}$ & $>>65$ & $31.7 / 32.9$ & $11.0 / 16.2$ & $11.9 / 15.9$ & nearly unworn & $16.0 / 18.8$ \\
\hline Ata06, TD8B, G-14, 16 & $\mathrm{P}_{3 / 4}$ & $d$ & $>23.5$ & 29.5/-- & $>15.8 /--$ & >14.7/-- & $9.1 / 10.6$ & 19.9 \\
\hline Ata2002, TD8B, G-7, 19 & $\mathrm{M}_{1 / 2}$ & $d$ & $>14.8$ & 23.3/-- & $14.3 /--$ & 11.9/-- &..$/ 5.2$ & 12.8/-- \\
\hline Ata02, TD8A, perfilados & $\mathrm{M}_{3}$ & $\mathrm{~s}$ & $>>36.8$ & 33.2/-- & 14.3/-- & 11.1/-- & $7.9 / 5.7$ & 13.7/-- \\
\hline Ata02, TD8B, G-7, 55 & $\mathrm{M}_{3}$ & $\mathrm{~s}$ & $>65.4$ & $29.4 / 32.7$ & $10.4 / 12.3$ & $8.1 / 11.6$ & nearly unworn & $8.6 / 14.4$ \\
\hline $\begin{array}{l}\text { Ata03, TD8B, G-6, } 18 \\
\text { fits Ata03, TD8B, G-6, } 17\end{array}$ & $\mathrm{M}_{2}$ & $\mathrm{~s}$ & $>81.8$ & $30.4 / 27.4$ & $13.4 / 15.9$ & $12.7 / 14.4$ & $9.1 / 11.4$ & 15.3 \\
\hline $\begin{array}{l}\text { Ata03, TD8B, G-6, } 17 \\
\text { fits Ata03, TD8B, G-6, } 18\end{array}$ & $M_{1}$ & $\mathrm{~s}$ & $>58.2$ & $30.8 / 27.8$ & $12.8 / 15.3$ & $10.3 / 13.0$ & $8.1 / 10.7$ & $14.7 / 14.7$ \\
\hline
\end{tabular}


Table 2

Measurements (in mm) of the decidual and permanent incisors of Equus altidens from Atapuerca TD8. The identifications of the tooth positions are tentative.

\begin{tabular}{|l|l|l|l|l|l|l|}
\hline number & & & DMDo & DMDb & DLLo & DLLb \\
\hline Ata94,TD8, t29, I-16, 28 & $\mathrm{I}^{2}$ & $\mathrm{~s}$ & 22.9 & 11.7 & 10.3 & 13.7 \\
\hline Ata94, TD8, G-16, 9 & $\mathrm{DI}_{3}$ & $\mathrm{~s}$ & 11.0 &.. & 7.0 &.. \\
\hline Ata94, TD8, H-16, 1 & $\mathrm{I}_{2}$ & $\mathrm{~d}$ & 13.7 & 11.4 & 10.6 & 11.7 \\
\hline Ata94, TD8, t29, I-16, sc & $\mathrm{DI}^{1}$ & $\mathrm{~s}$ & 18.2 & 13.1 & 8.5 & 9.7 \\
\hline Ata94, TD8, t28, H-16, sc & $\mathrm{I}_{3}$ & $\mathrm{~d}$ & $\geq 17.2$ & & 10.4 & \\
\hline Ata2002, Td8B, F-13, 7 & $\mathrm{I}^{2}$ & $\mathrm{~s}$ & 18.4 & -- & 10.6 & - \\
\hline Ata2002, TD8B, G-9, 48 & $\mathrm{I}_{2}$ & $\mathrm{~d}$ & 16.9 & 14.4 & 12.3 & $\approx 14.0$ \\
\hline Ata2002, TD8B, G-9, 41 & $\mathrm{I}_{2}$ & $\mathrm{~s}$ & 17.1 & 12.7 & 12.1 & $\approx 14.3$ \\
\hline Ata2002, TD8B, G-7, 23 & $\mathrm{DI}^{2}$ & $\mathrm{~d}$ & 19.3 & 17.1 & 8.3 &.. \\
\hline Ata2002, TD8B, G-7, 38 & $\mathrm{I}^{2 / 3}$ & $\mathrm{~d}$ & 17.6 & 13.4 & -- & - \\
\hline Ata03, TD8B, G-5, 54 & $\mathrm{I}_{2}$ & $\mathrm{~s}$ & 14.2 & & 10.6 & \\
\hline number & & & & & & \\
\hline Ata94, TD8, t28, I-16, 14 & $\mathrm{C}^{\mathrm{x}}$ & $\mathrm{s}$ & 13.5 & 9.2 & & \\
\hline
\end{tabular}


Table 3

Measurements of various limb bones of Equus altidens from Atapuerca TD8 (in mm and taken according to Eisenmann et al., 1988). The numbers in the headings refer to the number of the measurement according to Eicenmann et al. (1988), between brackets the acronyms as applied here. The values marked with an asterix (*) have been estimated (see section on methodology).

\begin{tabular}{|c|c|c|c|c|c|c|c|c|c|c|c|c|c|c|c|}
\hline Humerus & & $1(L)$ & $2(I)$ & 3 (DTmini) & 4 (DAPmini) & 5 (DTp) & 6 ("DAPp") & 7 (DTdf) & 8 (DAPd) & 9 (R1) & 10 (R2) & $11(\mathrm{R} 3)$ & R4 & & \\
\hline Ata2002, TD8B, G-8, 21 & $\mathrm{~s}$ & -- & -- & -- & -- & -- & -- & $\approx 76$ & -- & 51.7 & 37.0 & $\approx 45$ & 40.5 & & \\
\hline Metacarpal III & & 1 (L) & 2 (Lm) & 3 (DTmini) & 4 (DAP-3) & 5 (DTpf) & 6 (DAPpf) & 7 & 8 & 9 & 10 (DTd) & 11 (DTdf) & 12 (DAPd) & 13 & 14 \\
\hline Ata2002, TD8B, G-10, 35 & $d$ & $251.8^{*}$ & -- & 35.2 & -24.9 & 52.0 & 31.5 & $46.6^{*}$ & .. & .. & -- & $46.6^{*}$ & -- & -- & -- \\
\hline Calcaneum & & $1(\mathrm{~L})$ & $2(L u)$ & 3 (DTn) & 4 (DTh) & 5 (DAPh) & 6 (DTmax) & 7 (DAP) & DAPn & & & & & & \\
\hline ATA2002, TD8B, G-8, 67 & $\mathrm{~s}$ & 116.9 & 82.7 & 20.8 & 34.4 & -- & $\geq 47.7$ & & 46.8 & & & & & & \\
\hline Astragalus & & $1(L)$ & $2(R)$ & 3 & 4 (DT) & 5 (DTdf) & 6 (DAPdf) & 7 (DAP) & Lint & Lm & DTp & $\mathbf{R m}$ & & & \\
\hline Ata94, TD8, t29, I-16, 21 & $\mathrm{~s}$ & 59.2 & $>53.2$ & 30.7 & $>59.0$ & 48.2 & 35.3 & $\ldots$ & 60.2 & 45.2 & $\geq 45.4$ & & & & \\
\hline Ata2002, TD8B, G-8, 60 & $\mathrm{~s}$ & 61.6 & 62.1 & 31.6 & 62.3 & 53.1 & 36.3 & .. & 62.0 & 46.9 & 50.3 & 35.5 & & & \\
\hline Phalanx 1 & & $1(\mathrm{~L})$ & 2 (Ld) & 3 (DTmini) & 4 (DTp) & 5 (DAPp) & 6 (DTd) & 7 (DTdf) & 8 (DAPd) & 9 & 10 & 11 & 12 & 13 & \\
\hline Ata94, TD8, t31, I-16, 65 & $d$ & 86.8 & 79.7 & & 49.1 & $\geq 35.1$ & 42.9 & 40.2 & 25.3 & 53.6 & 69.8 & 69.5 & 14.0 & 15.5 & \\
\hline Ata03, DT8B, G-5, 49 & $\mathrm{~s} ?$ & -- & -- & -- & 58.8 & $\approx 40$ & -- & -- & -- & -- & -- & -- & - & -- & \\
\hline Ata03, TD8A, H-6, sc & d & -- & -- & -- & -- & -- & 47.9 & .. & 26.8 & -- & -- & -- & -- & -- & \\
\hline Ata06, TD8B, G-4, 110 & $?$ & -- & -- & -- & -- & -- & -- & -- & -- & -- & -- & -- & -- & -- & \\
\hline
\end{tabular}


Table 4

Measurements of the carpals and tarsals of Equus altidens from Atapuerca TD8 (in mm).

\begin{tabular}{|c|c|c|c|c|c|}
\hline Scaphoid & & DAP & DT & $\mathrm{Ha}$ & \\
\hline Ata03, TD8B, G-5, 14 & s & -- & $\geq 22.0$ & 26.7 & \\
\hline Ata06, TD8B G-4, 111 & $d$ & 37.3 & 25.3 & 28.1 & \\
\hline Lunar & & DAP & DTp & DTd & $\mathrm{Ha}$ \\
\hline ?Ata06, TD8b, H-3, 42 & s & 38.0 & 30.5 & 23.5 & 16.0 \\
\hline Ata95, TD8, H-16, t27, 6 & & 46.0 & 34.4 & $\geq 25.9$ & 30.6 \\
\hline Ata94, TD8, t27, H-16, 6 & s & 46.5 & 34.2 & $>6.1$ & 30.4 \\
\hline Ulnar & & DAP & DT & H & \\
\hline Ata2002, TD8B, F-12, 47 & s & 32.2 & 16.3 & 21.3 & \\
\hline Trapezoid & & DAP & DT & H & \\
\hline Ata94, TD8, t28, G-16, 35 & $\mathrm{~s}$ & 32.7 & 27.5 & 24.3 & \\
\hline Ata94, TD8, t29, I-16, 29 & s & 33.9 & 25.7 & 25.1 & \\
\hline Magnum & & DAP & DT & H & \\
\hline Ata2002, TD8B, G-8, 81 & d & 39.0 & 44.5 & $\geq 20.3$ & \\
\hline Ata04, TD8B, G-5, 45 & s & -- & 43.7 & -- & \\
\hline Navicular & & DAP & DT & & \\
\hline Ata03, TD8B, G-6, 41 & d & 36.3 & 49.6 & & \\
\hline Ata2002, TD8B, G-8, 54 & $d$ & 46.3 & 56.3 & & \\
\hline Ata2002, TD8B, G-8, 79 & s & 40.9 & 52.3 & & \\
\hline Cuboid & & DAP & DT & H & \\
\hline Ata2002, TD8B, G-8, 83 & $d$ & 38.4 & 25.4 & 28.8 & \\
\hline Ata03, TD8B,G-5, 14 & s & -- & $\geq 22.0$ & $>26.7$ & \\
\hline Cuneiform III & & DAP & DT & & \\
\hline Ata94, TD8, t29, H-16, 53 & s & 39.9 & 47.1 & & \\
\hline Ata2002, TD8B, G-8, 71 & s & 41.7 & 50.2 & & \\
\hline Ata2002, TD8B, F-11, 59 & $d$ & 43.8 & 54.5 & & \\
\hline Ata03, TD8B, G-6, 23 & d & 42.3 & 55.6 & & \\
\hline
\end{tabular}


Table 5

Measurements of the lateral metapodials, phalanges and sesamoids of Equus altidens from Atapuerca TD8 (in $\mathrm{mm}$ ).

\begin{tabular}{|c|c|c|c|c|c|c|c|c|}
\hline Mc II, Mc IV, Mt II, Mt IV & & & DAPp & DTp & $\mathbf{L}$ & & & \\
\hline Ata, 2002, TD8B, G-10, 55 & $d$ & Mc II & $>21.9$ & 15.8 & -- & & & \\
\hline Ata2002, TD8B, G-10, 36 & s & Mc IV & 19.7 & 14.4 & $>105$ & & & \\
\hline Ata2002, TD8B, F-11, 65 & $?$ & $?$ & -- & -- & -- & distal & & \\
\hline Ata03, TD8B, G-5, 51 & s & Mc IV & 19.2 & 13.6 & -- & & & \\
\hline Ata03, TD8B, G-15, 5 & $\mathrm{~s}$ & Mc IV & 18.6 & 13.5 & & & & \\
\hline Phalanx 2 & & 1 (L) & 2 & 3 (DTmini) & 4 (DTp) & 5 (DAPp) & 6 (DTdf) & DAPd \\
\hline Ata2002, TD8B, G-7, 95 & s & 43.2 & 32.9 & 43.5 & 45.8 & 29.2 & 43.5 & 25.6 \\
\hline Ata94, TD8, t27, H-16, 12 & .. & $\approx 54.5$ & $\approx 38.3$ & 53.6 & $\geq 62.0$ & 36.6 & -- & \\
\hline Ata2002, TD8B, G-7, 32 & $d ?$ & $\geq 44.4$ & .. & .. & 40.3 & 28.6 & 38.6 & -- \\
\hline Ata2002, TD8B, G-13, 9 & d & 51.9 & -- & 48.4 & 54.5 & -- & 49.6 & 27.6 \\
\hline Ata03, TD8B, G-5, 29 & $\mathrm{~s}$ & $\geq 51.9$ & 40.8 & .. & -- & 34.2 & $\geq 48.0$ & 28.2 \\
\hline Ata03, TD8B, G-5, 42 & s & 44.4 & 32.4 & 38.1 & $\geq 46.3$ & 29.6 & 42.1 & 26.5 \\
\hline Phalanx 3 & & 1 (Lb) & $2(L d)$ & 3 (DT) & 4 (DTpf) & 5 (DAPpf) & DAP (H) & 6 \\
\hline Ata94, TD8, t28, G-17, 11 & $?$ & -- & -- & -- & -- & 28.3 & -- & \\
\hline Ata03, TD8B, H-15, 7 & $?$ & juvenile & $\approx 30$ & -- & -- & -- & -- & \\
\hline Ata03, TD8B, G-6, 15 & s & $>55.4$ & $>56.9$ & & 51.6 & 26.3 & 44.1 & 48 \\
\hline Ata03, TD8B, G-15, 12 & $d ?$ & 55.6 & 53.5 & $\geq 63.1$ & 44.8 & 27.9 & $\approx 41.5$ & 53 \\
\hline Sesamoid-1-ax/abax & & DAP & DAP' & DT & $\mathbf{L}$ & & & \\
\hline Ata03, TD8B, G-4, 21 & r & 29.9 & 27.8 & 27.9 & 36.0 & & & \\
\hline Sesamoid-3 & & DAP & DT & $\mathbf{L}$ & & & & \\
\hline Ata2002, TD8B, F-10, 13 & s? & 15.8 & 46.0 & 12.9 & & & & \\
\hline
\end{tabular}


Table 6

Measurements of the teeth and bones of Stephanorhinus aff. etruscus from Atapuerca TD8.

\begin{tabular}{|l|l|l|l|l|l|l|l|}
\hline upper cheek teeth & & element & DAP & DAPb & DTa & DTp & H \\
\hline Ata06, TDbB, H-4, 8 & d & $\mathrm{D}^{2}$ & $>>38.6$ & -- & -- & - & \\
\hline Ata94, TD8, t29, I-16, 35 & s & $\mathrm{P}^{2}$ & 34.6 & 30.5 & 31.6 & 35.1 & 45.6 \\
\hline Ata94, TD8, t29, H-16, 52 & .. & $\mathrm{M}^{\times}$ & -- & -- & -- & -- & \\
\hline Ata94, TD8, t29, H-16, 63 & d & $\mathrm{D}^{3 / 4} / \mathrm{M}^{1 / 1}$ & 36.7 & -- & -- & -- & \\
\hline & & & & & & & \\
\hline lower cheek teeth & & element & DAP & DAPb & DTa & DTp & H \\
\hline Ata2002, TD8B, F-12, 50 & d & D 2 & 42.8 & 40.6 & 19.7 & 22.0 & \\
\hline & & & & & & & \\
\hline Phalanx III-1 & & DAPp & DTp & L & Ldors & DAPd & DTd \\
\hline Ata94, TD8, t28, I-16, 16 & s & 31.3 & 43.8 & 42.0 & 30.6 & 21.0 & $\geq 35.9$ \\
\hline & & & & & & & \\
\hline Phalanx III-3 & & DApp & DAPpf & DTpf & DTp & L & \\
\hline TD8 (A) & .. & -- & 20.0 & -- & -- & -- & \\
\hline
\end{tabular}


Table 7

Measurements of the teeth and bones from Atapuerca TD8 assigned to Cervus elaphus.

\begin{tabular}{|c|c|c|c|c|c|c|c|c|c|c|}
\hline & & & DAP & $\mathrm{DAPb}$ & DTa & DTp & DTpp & $\mathrm{Ha}(\mathrm{Hbu})$ & $\mathrm{Ta}$ & taxon \\
\hline Ata94, TD8, t28, l-16, 9 & $s$ & $\mathrm{P}^{3}$ & 17.0 & 16.9 & 17.5 & 17.6 & & & & C \\
\hline Incisor & & & DT & DMd & DLL & DTroot & DLLroot & & & \\
\hline Ata2002, TD8b, F-13, 2 & $\mathrm{~s}$ & $\mathrm{I}_{3}$ ? & -- & 6.7 & 7.4 & 4.4 & 5.4 & & & \\
\hline Ata03, TD8b, G-6, bn & $d$ & $\mathrm{I}_{3}$ & -- & 6.6 & 6.1 & -- & -- & & & $C ?$ \\
\hline Scapula & & DAPd & DAPpf & DTd & DAPn & DTn & & & & \\
\hline Ata04, TD8b, G-5, 4 & $d$ & 64.6 & 47.4 & -- & 43.8 & 21.1 & & & & $C ?$ \\
\hline tibia & & DAPd & & & & & & & & \\
\hline Ata94, TD8, t28, G-17, 22 & $d$ & $\geq 28.1$ & & & & & & & & C \\
\hline Calcaneum & & DAPh & DTh & DAPn & DTn & DAPsf & DTfs & DAPm & $\mathbf{L}$ & \\
\hline Ata94, TD8, t29, G-16, 59 & $d$ & juv & & 31.0 & 16.5 & -- & -- & -- & -- & $C ?$ \\
\hline Ata94, TD8, t28, I-17, 1 & $\mathrm{~s}$ & -- & -- & -- & -- & $\approx 42.8$ & & & & $C ?$ \\
\hline Ata06, TD8b, G-4, 125 & $d$ & 29.0 & 23.3 & juv & & & & & & $C ?$ \\
\hline Metacarpal & & DTd & $\begin{array}{l}\text { left } \\
\text { DAP }\end{array}$ & $\begin{array}{l}\text { left } \\
\text { DT }_{\text {IIIIIV }}\end{array}$ & $\begin{array}{l}\text { right } \\
\text { DAP }_{\text {IIIIIV }}\end{array}$ & $\begin{array}{l}\text { right } \\
\text { DT }_{\text {IIIIIV }}\end{array}$ & & & & \\
\hline Ata04, TD8b, G.5, remofido & $?$ & $\approx 58$ & 31.7 & 25.7 & 32.3 & 27.7 & & & & \\
\hline Phalanx & & type & DAPp & DAPpf & DTp & $\mathbf{L}$ & DAPd & DTd & & \\
\hline Ata94, TD8, H-16, 19 & I & III/IV 1 & juv & & & & $>18.7$ & $>18.4$ & & $C ?$ \\
\hline Ata94, TD8, t28, G-16, 32 & I & III/IV 1 & juv & & & & $\approx 18.3$ & $\approx 19.5$ & & $C ?$ \\
\hline Ata03, TD8b, I-9, 72 & $r$ & III/IV 1 & -- & -- & -- & -- & 16.9 & 18.7 & & C \\
\hline Ata94, TD8, t29, H-16, 59 & I & III/IV 2 & $\geq 32.7$ & & 24.8 & & juv & & & $C ?$ \\
\hline Ata94, TD8, t29, I/H-16, sc & I & III/IV 2 & -- & & -- & -- & -- & 21.9 & & $C ?$ \\
\hline Ata04, Td8b, G-14, 4 & I & III/IV 2 & 26.1 & & 24.2 & & juv & & & $C ?$ \\
\hline Ata05, TD8b, F-13, 2 & $r$ & III/IV 2 & 33.2 & & 24.9 & 49.5 & 30.4 & 22.1 & & C \\
\hline
\end{tabular}


Table 8

Measurements of the teeth from Atapuerca TD8 assigned to Eucladoceros (E) and Megaceroides (M).

\begin{tabular}{|c|c|c|c|c|c|c|c|c|c|c|}
\hline & & & DAP & DAPb & DTa & DTp & DTpp & $\mathrm{Ha}(\mathrm{Hbu})$ & $\mathrm{Ta}$ & taxon \\
\hline Ata2002, TD8b, G-12, 10 & $\mathrm{P}^{4}$ & s & 19.3 & 18.7 & & 26.6 & & & & $E ?$ \\
\hline Ata2002, TD8b, G-12, 26 & $\mathrm{M}_{3}$ & d & 44.3 & 42.8 & 20.7 & 19.9 & 11.4 & & & $E$ \\
\hline Ata06, Td8b, G-4, 115 & $\mathrm{P}^{2}$ & $\mathrm{~s}$ & 20.7 & 20.0 & 18.5 & 19.8 & & $>21.7$ & & $E ?$ \\
\hline Ata94, TD8, G-16, 19 & $\mathrm{P}_{3}$ & $\mathrm{~s}$ & 23.3 & & 11.2 & 12.9 & & $>20.1$ & & $E ?$ \\
\hline \multirow[t]{6}{*}{ Ata2002, TD8b, G-7, G-3 } & $\mathrm{M}_{3}$ & $d$ & 38.3 & 37.4 & 15.5 & 11.8 & 9.9 & & & \multirow[t]{6}{*}{$M$} \\
\hline & $\mathrm{M}_{2}$ & & 30.8 & 27.6 & 18.1 & 17.4 & & & 0.7 & \\
\hline & $\mathrm{M}_{1}$ & & $\approx 24.4$ & -- & -- & -- & & & & \\
\hline & $\mathrm{P}_{4}$ & & 22.6 & 21.2 & 12.6 & 13.8 & & & & \\
\hline & $\mathrm{P}_{3}$ & & 22.3 & 20.5 & 11.3 & 12.4 & & & & \\
\hline & $\mathrm{P}_{2}$ & & 17.9 & 16.2 & 8.5 & 9.8 & & & & \\
\hline
\end{tabular}


Table 9

Measurements of the bones from Atapuerca TD8 assigned to Eucladoceros $(E)$ and Megaceroides $(M)(*=$ juvenile).

\begin{tabular}{|c|c|c|c|c|c|c|c|c|c|c|c|c|}
\hline Scaphoid & & DAP & DT & $\mathrm{Ha}$ & & & & & & & & \\
\hline $\begin{array}{l}\text { Ata03, TD8b, G-5, } 58 \\
\text { Goes with lunar no. } 59\end{array}$ & $d$ & 45.8 & 28.9 & $\geq 32.0$ & & & & & & & & \\
\hline Lunar & & DAP & DTp & DTd & $\mathrm{Ha}$ & & & & & & & \\
\hline Ata03, TD8b, G-5, 56 & $\mathrm{~s}$ & 38.7 & 27.7 & 17.9 & 28.7 & & & & & & & \\
\hline Ata03, TD8b, G-5, 59 & $d$ & 37.8 & 28.7 & 20.6 & 30.1 & & & & & & & \\
\hline Calcaneum & & DAPh & DTh & DAPn & DTn & DAPsf & DTfs & DAPm & $\mathbf{L}$ & Lu & LI & \\
\hline Ata03, TD8b, G-5, 40 & $d$ & 49.7 & 41.2 & 43.4 & 25.4 & 58.5 & 52.0 & 62.2 & 165 & 108.0 & 65.0 & $E$ \\
\hline Astragalus & & Lext & Lm & Lint & DTp & DTp & & & & & & \\
\hline Ata94, TD8, I-17, sc & $\mathrm{s}$ & 71.7 & 58 & 69.1 & 45.8 & 45.5 & & & & & & $M ?$ \\
\hline Ata94, TD8, t28, G-17, 4 & $\mathrm{~s}$ & $>73.3$ & 60.9 & $>72.0$ & 47.8 & $>41.4$ & & & & & & $M ?$ \\
\hline Metapodial & & type & DTd & $\begin{array}{l}\text { left } \\
\text { DAP }{ }_{\text {IIIIV }}\end{array}$ & $\begin{array}{l}\text { left } \\
\text { DT }_{\text {IIIIV }}\end{array}$ & $\begin{array}{l}\text { right } \\
\text { DAP IIIIV }\end{array}$ & $\begin{array}{l}\text { right } \\
\text { DT }_{\text {IIIIVIV }}\end{array}$ & & & & & \\
\hline Ata04, TD8b, G-5, removido & $?$ & Mc & $\approx 58$ & 31.7 & 25.7 & 32.3 & 27.7 & & & & & $M ?$ \\
\hline Ata03, TD8b, G-12, 9 & $?$ & Mc & 56.0 & 36.1 & 25.3 & 35.3 & 25.5 & & & & & $M ?$ \\
\hline Ata05, TD8b, H-3, 49* & $?$ & $?$ & & -- & $>26.8$ & & & & & & & $M ?$ \\
\hline Ata05, TD8b, H-3, 34* & $?$ & $?$ & & & & -- & -- & & & & & $M ?$ \\
\hline Phalanx 1 & & type & DAPp & DAPpf & DTp & $\mathbf{L}$ & DAPd & DTd & & & & \\
\hline Ata2002, TD8b, G-7, 91 & 1 & III/IV 1 & 34.5 & 31.7 & 31.6 & 71.9 & 24.8 & 32.0 & & & & $M$ \\
\hline Ata03, TD8b, G-16, 16 & I & III/IV 1 & 33.3 & & 28.1 & & juv & & & & & $M ?$ \\
\hline Ata04, TD8b, F-14, 10 & $r$ & III/IV 1 & $\geq 33.1$ & 31.7 & 30.3 & -- & -- & -- & & & & $M ?$ \\
\hline Ata06, TD8b, G-04, 113 & 1 & III/IV 1 & -- & $>31.3$ & $>29.1$ & 70.9 & 23.6 & 30.2 & & & & $M$ \\
\hline Phalanx & & type & DAPp & DAPp' & DTp & $\mathbf{L}$ & DAPd & DTd & & & & \\
\hline Ata06, TD8b, G-3, 48 & I & III/IV 2 & $>41.7$ & $\approx 40.2$ & 35.1 & 62.5 & 37.0 & 29.6 & & & & $M ?$ \\
\hline Ata06, TD8b, G-3, 71 & I & III/IV 2 & $>42.7$ & 34.6 & 63.1 & 37.3 & 29.2 & -- & 21.9 & & & \\
\hline Ata06, TD8b, G-4, 48 & & II/N 2 & 18.9 & & 8.1 & 20.2 & 14.5 & 10.3 & & & & \\
\hline
\end{tabular}


Table 10

Measurements of the isolated upper cheek teeth of Dama vallonnetensis from Atapuerca TD8.

\begin{tabular}{|c|c|c|c|c|c|c|c|}
\hline number & tooth & s/d & DAP & DAPb & DTa & DTp & $\mathrm{Ha}(\mathrm{Hbu})$ \\
\hline Ata94, TD8, t28, G-16, 51 & $M^{3}$ & $d$ & $\approx 16.4$ & & -- & 16.5 & \\
\hline Ata94, TD8, t29, I-19, 48 & $M^{3}$ & $\mathrm{~s}$ & 18.8 & 18.8 & 19.0 & 16.8 & \\
\hline Ata2002, TD8b, G-13, 18 & $M^{3}$ & $d$ & 18.7 & 17.1 & 18.1 & 17.1 & 18.3 \\
\hline Ata03, TD8b, G-5, bn & $M^{3}$ & $\mathrm{~s}$ & -- & -- & -- & 16.2 & \\
\hline Ata03, TD8b, H-4, bn & $M^{3}$ & $d$ & 18.1 & 16.5 & 17.9 & 16.3 & \\
\hline Ata06,TD8b, G-3, 45 & $M^{3}$ & $d$ & 19.8 & 17.9 & 19.9 & 17.6 & \\
\hline Ata2002, Tdb, G-12, 36 & $M^{x}$ & $\mathrm{~s}$ & -- & -- & -- & $\leq 17.1$ & \\
\hline Ata06, TD8b, G-4, 13 & $M^{x}$ & & -- & -- & -- & -- & \\
\hline Ata94, TD8, t29, I-19, 50 & $M^{x}$ & $d$ & -- & -- & -- & -- & \\
\hline Ata2002, TD8b, F-13, 17 & $M^{x}$ & $d$ & -- & -- & -- & 17.0 & \\
\hline Ata94, TD8, t29, I-16, 50 & $M^{x}$ & $d$ & -- & -- & -- & -- & \\
\hline Ata06, Td8b, G-3, 10 & $M^{2}$ & $\mathrm{~s}$ & 19.3 & 18.0 & 20.1 & 19.0 & \\
\hline Ata06, TD8b, G-3, 86 & $\mathrm{M}^{2}$ & $\mathrm{~s}$ & -- & -- & -- & 20.1 & \\
\hline Ata06, Td8b, H-4, 13 & $M^{2}$ & $\mathrm{~s}$ & 20.3 & 18.2 & 19.7 & -- & \\
\hline Ata94, TD8, t29, I-16, 43 & $M^{1}$ & $d$ & 18.8 & 16.5 & 18.1 & 17.7 & \\
\hline Ata06, TD8b, G-3, 2 & $M^{x}$ & $d$ & 18.7 & 18.7 & -- & -- & \\
\hline Ata03, TD8b, G-6, 22 & $M^{2}$ & $\mathrm{~s}$ & 17.9 & 16.8 & -- & -- & \\
\hline Ata03, TD8b, G-4, 10 & $M^{x}$ & $\mathrm{~s}$ & -- & -- & 18.8 & -- & \\
\hline Ata06, TD8b, G-3, 11 & $M^{1 / 2}$ & & -- & -- & -- & $\geq 17.2$ & \\
\hline Ata2002, TD8b, G-15, 2 & $M^{1}$ & s & 17.2 & 15.1 & 16.6 & 17.4 & \\
\hline Ata06, TD8b, G-4, 87 & $M^{1}$ & s & 18.2 & 14.9 & -- & -- & \\
\hline Ata06, TD8b, G-4, 140 & $M^{1}$ & $d$ & -- & -- & -- & 16.9 & \\
\hline Ata06, TD8b, H-3, 23 & $M^{1}$ & $\mathrm{~s}$ & 19.2 & 16.5 & 18.1 & 17.7 & \\
\hline Ata94, TD8, G-16, 10 & $D^{x} / M^{x}$ & $d$ & -- & -- & -- & -- & \\
\hline Ata94, TD8, t28, G-17, 20 & $\mathrm{P}^{4}$ & $\mathrm{~s}$ & 12.9 & 10.3 & & 15.5 & $>13.9$ \\
\hline Ata2002, TD8b, G-7, 85 & $\mathrm{P}^{4}$ & $d$ & 11.3 & 10.9 & & 15.0 & \\
\hline Ata06, TD8b, G-3, 44 & $\mathrm{P}^{4}$ & $d$ & 12.7 & 11.3 & & 16.3 & 15.8 \\
\hline Ata06, TD8b, H-3, 10 & $\mathrm{P}^{3}$ & $\mathrm{~s}$ & 14.0 & 13.2 & & 13.6 & \\
\hline Ata94,TD8, t16, G-16, sc & $P^{2}$ & $d$ & $>12$ & $>12$ & 11.4 & -- & \\
\hline Ata05,TD8b, G-13, 4 & $\mathrm{P}^{2}$ & s & 12.8 & 11.8 & 10.4 & 11.6 & \\
\hline Ata06, TD8b, H-4, 6 & $\mathrm{P}^{2}$ & $d$ & 12.7 & 12.3 & 11.0 & 12.3 & \\
\hline Ata2002, TD8b, F-12, 21 & $D^{4}$ & $d$ & -- & -- & -- & -- & \\
\hline Ata2002, TD8b, G-8, 22 & $D^{4}$ & $\mathrm{~s}$ & 14.4 & 13.7 & 14.6 & 14.4 & \\
\hline
\end{tabular}


Table 11

Measurements of the articulated upper cheek teeth of Dama vallonnetensis from Atapuerca TD8.

\begin{tabular}{|c|c|c|c|c|c|c|}
\hline number & tooth & s/d & DAP & $\mathrm{DAPb}$ & DTa & DTp \\
\hline Ata2002, TD8b, G-7, 12 & $\begin{array}{l}M^{3} \\
M^{2}\end{array}$ & $s$ & $\begin{array}{l}19.4 \\
>15.8\end{array}$ & $\begin{array}{l}17.2 \\
>15.8\end{array}$ & $\begin{array}{l}17.7 \\
--\end{array}$ & $\begin{array}{l}15.6 \\
18.5\end{array}$ \\
\hline Ata2002, TD8b, G-11, 14 & $\begin{array}{l}M^{3} \\
M^{2} \\
M^{1} \\
P^{3} \\
D^{4} \\
D^{3} \\
D^{2}\end{array}$ & $d$ & $\begin{array}{l}20.6 \\
-- \\
18.4 \\
13.4 \\
15.0 \\
-- \\
13.0\end{array}$ & $\begin{array}{l}17.9 \\
-- \\
15.8 \\
11.6 \\
12.7 \\
-- \\
12.2\end{array}$ & $\begin{array}{l}20.4 \\
-- \\
17.5 \\
-- \\
14.3 \\
9.1 \\
--\end{array}$ & $\begin{array}{l}\approx 19.0 \\
- \\
18.3 \\
- \\
14.7 \\
-- \\
--\end{array}$ \\
\hline Ata03, TD8b, G-3, 6 & $\begin{array}{l}M^{2} \\
M^{1} \\
P^{4}\end{array}$ & $d$ & $\begin{array}{l}>20.5 \\
18.6 \\
--\end{array}$ & $\begin{array}{l}18.7 \\
17.0 \\
--\end{array}$ & $\begin{array}{l}20.6 \\
--\end{array}$ & $\begin{array}{l}19.2 \\
-- \\
--\end{array}$ \\
\hline Ata03, TD8b, G-5, 38 & $\begin{array}{l}P^{4} \\
P^{3} \\
P^{2}\end{array}$ & $s$ & $\begin{array}{l}-- \\
12.9 \\
12.2\end{array}$ & $\begin{array}{l}-- \\
11.7 \\
11.2\end{array}$ & $\begin{array}{l}12.9 \\
10.7\end{array}$ & $\begin{array}{l}- \\
13.0 \\
11.4\end{array}$ \\
\hline Ata03, TD8b, G-5, 45 & $\begin{array}{l}M^{3} \\
M^{2} \\
M^{1}\end{array}$ & $s$ & $\begin{array}{l}19.9 \\
. . \\
\approx 16.6\end{array}$ & $\begin{array}{l}18.6 \\
. . \\
\approx 16.6\end{array}$ & $\begin{array}{l}18.6 \\
-- \\
\approx 16.2\end{array}$ & $\begin{array}{l}15.6 \\
. . \\
--\end{array}$ \\
\hline Ata06, TD8b, G-3, 110 & $\begin{array}{l}M^{1} \\
P^{4}\end{array}$ & $d$ & $\begin{array}{l}17.0 \\
11.9\end{array}$ & $\begin{array}{l}17.0 \\
11.4\end{array}$ & 18.9 & $\begin{array}{l}18.4 \\
15.6\end{array}$ \\
\hline Ata06, TD8b, G-4, 22 & $\begin{array}{l}P^{4} \\
P^{2}\end{array}$ & $\mathrm{~s}$ & $\begin{array}{l}10.7 \\
--\end{array}$ & $\begin{array}{l}9.5 \\
--\end{array}$ & $\begin{array}{l}-- \\
--\end{array}$ & $\begin{array}{l}-- \\
--\end{array}$ \\
\hline Ata06,TD8b, G-4, 100 & $\begin{array}{l}M^{3} \\
M^{2}\end{array}$ & $s$ & $\begin{array}{l}-- \\
19.4\end{array}$ & $-\overline{17.3}$ & $\begin{array}{l}18.7 \\
19.5\end{array}$ & $\begin{array}{l}\approx 16.7 \\
18.3\end{array}$ \\
\hline Ata06, TD8b, G-4, 138 & $\begin{array}{l}M^{2} \\
M^{1} \\
P^{4} \\
P^{3}\end{array}$ & & $\begin{array}{l}\approx 19.2 \\
18.9 \\
13.1 \\
12.4\end{array}$ & $\begin{array}{l}\approx 16.2 \\
17.3 \\
11.6 \\
11.5\end{array}$ & $\begin{array}{l}\ddot{17.9} \\
--\end{array}$ & $\begin{array}{l}. . \\
- \\
15.2 \\
--\end{array}$ \\
\hline Ata2002, TD8b, G-7, 75 & $\begin{array}{l}M^{1} \\
D^{4}\end{array}$ & $\mathrm{~s}$ & $\begin{array}{l}19.4 \\
15.5\end{array}$ & $\begin{array}{l}17.9 \\
14.0\end{array}$ & $\begin{array}{l}17.9 \\
15.2\end{array}$ & $\begin{array}{l}17.7 \\
15.2\end{array}$ \\
\hline
\end{tabular}


Table 12

Measurements of the isolated lower cheek teeth of Dama vallonnetensis from Atapuerca TD8.

\begin{tabular}{|c|c|c|c|c|c|c|c|c|c|}
\hline number & tooth & s/d & DAP & $\mathrm{DAPb}$ & DTa & DTp & DTpp & $H(\mathrm{Ha})$ & $\mathrm{Ta}$ \\
\hline Ata05, Td8b, F-13, 17 & $\mathrm{M}_{3}$ & $d$ & 26.9 & 26.6 & 12.5 & 11.9 & 7.6 & & 0.9 \\
\hline Ata02, TD8b, F-12, 43 & $\mathrm{M}_{3}$ & s & -- & -- & 11.9 & 11.6 & -- & & \\
\hline Ata05, TD8b, F-13, 15 & $\mathrm{M}_{3}$ & $d$ & 25.2 & 24.7 & 11.3 & 10.8 & 6.9 & & \\
\hline Ata06, TD8b, H-4, 21 & $\mathrm{M}_{3}$ & d & $\geq 24.2$ & .. & .. & .. & .. & & \\
\hline Ata94, TD8, t29, I-16, 42 & $\mathrm{M}_{2}$ & $s$ & 18.1 & 17.2 & 11.2 & 11.8 & & & \\
\hline Ata2002, TD8b, G-7, 11 & $\mathrm{M}_{2}$ & $d$ & -- & -- & $\geq 11.5$ & - & & & \\
\hline Ata2002, TD8b, G-10, 26 & $\mathrm{M}_{2}$ & $d$ & 20.1 & 19.2 & 12.4 & 12.3 & & & \\
\hline Ata06, TD8b, G-4, 25 & $\mathrm{M}_{2}$ & s & 20.4 & 18.6 & 11.5 & -- & & & \\
\hline Ata2002, TD8b, G-9, 59 & $\mathrm{M}_{2 ?}$ & $s$ & & & 12.8 & & & & \\
\hline Ata94, TD8, t29, I-1, 54 & $M_{1}$ & s & 16.1 & 15.7 & 10.8 & 10.7 & & & \\
\hline Ata2002, TD8b, G-8, 11 & $M_{1}$ & $\mathrm{~s}$ & 13.7 & $>13.7$ & 10.9 & 10.9 & & & \\
\hline Ata2002, TD8b, G-8, 43 & $\mathrm{M}_{1}$ & s & 18.6 & 16.9 & 10.6 & 10.7 & & & \\
\hline Ata06, TD8b, G-3, 51 & $\mathrm{M}_{1}$ & $d$ & 16.1 & 16.1 & 10.6 & 11.0 & & & 0.5 \\
\hline Ata06, TD8b, H-4, 2 & $\mathrm{M}_{1}$ & $d$ & 21.3 & 17.8 & 11.0 & 10.9 & & 17.5 & \\
\hline Ata03, TD8b, G-6, 27 & $\mathrm{P}_{4}$ & $\mathrm{~s}$ & 12.3 & 12.3 & 9.2 & 8.0 & & & \\
\hline Ata03, TD8b, G-6, bn & $\mathrm{P}_{4}$ & $d$ & 14.7 & 13.4 & 9.0 & 8.6 & & & \\
\hline Ata05, TD8b, H-3, 6 & $\mathrm{P}_{4}$ & $d$ & 13.9 & 12.5 & 8.0 & 8.9 & & & \\
\hline Ata06, TD8b, G-4, 49 & $\mathrm{P}_{4}$ & d & 13.0 & 11.9 & 6.9 & 7.7 & & & \\
\hline Ata06, TD8b, H-3, 12 & $\mathrm{P}_{4}$ & $\mathrm{~s}$ & 13.5 & 12.1 & 7.6 & 7.4 & & & \\
\hline Ata06, TD8b, G-4, 84 & $\mathrm{P}_{4}$ & $d$ & 12.5 & 11.3 & 6.4 & 7.4 & & & \\
\hline Ata2002, TD8b, G-8, 44 & $\mathrm{P}_{4}$ & $\mathrm{~s}$ & 13.7 & 12.6 & 8.0 & 7.8 & & 13.2 & \\
\hline Ata2002, TD8b, G-8, 16 & $\mathrm{P}_{3}$ & $\mathrm{~s}$ & 12.9 & 11.6 & 8.0 & 8.5 & & & \\
\hline Ata2002, TD8b, G-8, 42 & $\mathrm{P}_{3}$ & & 12.2 & 11.4 & $\geq 6.6$ & -- & & & \\
\hline Ata2002, TD8b, G-8, 47 & $\mathrm{P}_{2}$ & $\mathrm{~s}$ & 10.9 & 9.5 & 6.3 & 7.1 & & & \\
\hline Ata06, TD8b, G-4, 1 & $\mathrm{P}_{2}$ & $\mathrm{~s}$ & 9.8 & 8.5 & 5.8 & 6.5 & & & \\
\hline Ata06, TD8b, G-4, 12 & $\mathrm{D}_{4}$ & $\mathrm{~s}$ & -- & -- & 7.9 & 9.0 & -- & & \\
\hline Ata06, Td8b, H-4, 4 & $\mathrm{D}_{3}$ & $d$ & 13.8 & 13.5 & 5.6 & 7.8 & & & \\
\hline Ata03, TD8b, G-5, bn & $\mathrm{D}_{2}$ & $\mathrm{~s}$ & 8.9 & 8.9 & 3.9 & 5.0 & & & \\
\hline
\end{tabular}


Table 13

Measurements of the associated lower cheek teeth and mandibles of Dama vallonnetensis from Atapuerca TD8.

\begin{tabular}{|c|c|c|c|c|c|c|c|c|c|c|c|c|}
\hline number & & & DAP & DAPb & DTa & DTp & DTpp & $\mathrm{Ha}$ & $\mathrm{Ta}$ & D & w & $\begin{array}{l}\text { DT } \\
\text { condyle }\end{array}$ \\
\hline Ata94, TD8, t29, H-16, 47 & $\begin{array}{l}M_{1} \\
P_{4} \\
P_{3}\end{array}$ & $d$ & $\begin{array}{l}16.5 \\
14.4 \\
13.6\end{array}$ & & $\begin{array}{l}10.6 \\
8.1 \\
7.2\end{array}$ & $\begin{array}{l}11.6 \\
8.7 \\
8.3\end{array}$ & & & & $\begin{array}{l}\approx 31.1 \\
\approx 28.4 \\
\approx 27.3\end{array}$ & & \\
\hline Ata2002, TD8b, G-11, 4 & $\begin{array}{l}M_{3} \\
M_{2}\end{array}$ & $d$ & $\begin{array}{l}27.4 \\
20.0\end{array}$ & $\begin{array}{l}26.7 \\
19.0\end{array}$ & $\begin{array}{l}11.5 \\
12.2\end{array}$ & $\begin{array}{l}10.8 \\
11.3\end{array}$ & 5.7 & & & & & \\
\hline Ata2002, TD8b, F-12, 14 & $\begin{array}{l}M_{2} \\
M_{1}\end{array}$ & $d$ & $\begin{array}{l}21.5 \\
17.3\end{array}$ & $\begin{array}{l}19.4 \\
16.6\end{array}$ & $\begin{array}{l}12.9 \\
11.3\end{array}$ & $\begin{array}{l}11.8 \\
10.9\end{array}$ & & & & & & \\
\hline Ata03,TD8b, G-5, 50 & $\begin{array}{l}M_{3} \\
M_{2} \\
M_{1} \\
P_{4} \\
P_{3} \\
P_{2}\end{array}$ & $\mathrm{~s}$ & $\begin{array}{l}26.3 \\
20.3 \\
12.5 \\
14.9 \\
13.9 \\
10.6\end{array}$ & $\begin{array}{l}24.7 \\
17.9 \\
15.3 \\
13.3 \\
11.9 \\
10.0\end{array}$ & $\begin{array}{l}11.5 \\
11.9 \\
10.5 \\
8.2 \\
6.3 \\
6.0\end{array}$ & $\begin{array}{l}11.3 \\
11.7 \\
11.2 \\
9.2 \\
8.2 \\
6.7\end{array}$ & 6.9 & & & & & \\
\hline Ata03, TD8b, H-15, 8 & $\begin{array}{l}M_{3} \\
M_{2} \\
M_{1}\end{array}$ & $\mathrm{~s}$ & $\begin{array}{l}27.0 \\
18.7 \\
--\end{array}$ & $\begin{array}{l}26.0 \\
17.6 \\
--\end{array}$ & $\begin{array}{l}. . \\
\ddot{10.8}\end{array}$ & $\begin{array}{l}10.6 \\
. . \\
--\end{array}$ & 6.7 & & & & & \\
\hline Ata03, Td8b, G-6, 28 & $\begin{array}{l}M_{3} \\
M_{2} \\
M_{1}\end{array}$ & $\mathrm{~s}$ & $\begin{array}{l}27.0 \\
18.7 \\
--\end{array}$ & $\begin{array}{l}26.0 \\
17.6 \\
--\end{array}$ & $\begin{array}{l}. . \\
\ddot{10.8}\end{array}$ & $\begin{array}{l}10.6 \\
. . \\
--\end{array}$ & 6.7 & & & & & \\
\hline Ata03, TD8b, H-5, nc & $\begin{array}{l}\mathrm{P}_{4} \\
\mathrm{P}_{3}\end{array}$ & $d$ & $\begin{array}{l}14.2 \\
--\end{array}$ & $\begin{array}{l}>14.2 \\
--\end{array}$ & $\overline{--}$ & $\overline{--}$ & & & & & & \\
\hline Ata05, TD8b, G-3, 1 & $\begin{array}{l}M_{2} \\
M_{1} \\
P_{4}\end{array}$ & $\mathrm{~s}$ & & $\begin{array}{l}18.1 \\
17.5 \\
13.9\end{array}$ & $\begin{array}{l}17.7 \\
11.1 \\
12.3\end{array}$ & $\begin{array}{l}12.2 \\
10.1 \\
8.4\end{array}$ & $\begin{array}{l}12.1 \\
10.9 \\
8.5\end{array}$ & & $\begin{array}{l}0.6 \\
0.5\end{array}$ & & & \\
\hline Ata05, TD8b, H-3, 33 & $\begin{array}{l}\mathrm{P}_{4} \\
\mathrm{P}_{3}\end{array}$ & $\mathrm{~s}$ & $\begin{array}{l}13.2 \\
12.9\end{array}$ & $\begin{array}{l}12.4 \\
11.8\end{array}$ & $\begin{array}{l}8.7 \\
7.3\end{array}$ & $\begin{array}{l}8.4 \\
7.8\end{array}$ & & & & & & \\
\hline Ata06, TD8b, G-3, 62 & $\begin{array}{l}M_{3} \\
M_{2} \\
M_{1} \\
P_{4} \\
P_{3} \\
P_{2}\end{array}$ & d & $\begin{array}{l}\approx 25 \\
19.9 \\
18.0 \\
13.9 \\
13.4 \\
10.9\end{array}$ & $\begin{array}{l}\approx 23 \\
18.2 \\
16.5 \\
12.6 \\
12.0 \\
9.4\end{array}$ & $\begin{array}{l}10.9 \\
11.3 \\
10.2 \\
8.3 \\
6.5 \\
5.2\end{array}$ & $\begin{array}{l}10.7 \\
11.3 \\
10.3 \\
8.2 \\
7.4 \\
6.6\end{array}$ & & & & $\begin{array}{l}25.9 \\
27.0 \\
24.9 \\
21.9 \\
22.1 \\
22.8\end{array}$ & $\begin{array}{l}17.6 \\
10.8 \\
13.3 \\
13.0 \\
12.2 \\
9.8\end{array}$ & \\
\hline Ata06, TD8b, G-4, 57 & $\begin{array}{l}M_{3} \\
M_{2} \\
M_{1} \\
P_{4} \\
P_{3} \\
P_{2} \\
\end{array}$ & d & $\begin{array}{l}26.5 \\
21.1 \\
18.7 \\
14.4 \\
13.5 \\
10.7 \\
\end{array}$ & $\begin{array}{l}26.1 \\
18.7 \\
16.8 \\
13.5 \\
12.0 \\
9.5 \\
\end{array}$ & $\begin{array}{l}11.3 \\
11.6 \\
10.6 \\
8.8 \\
7.7 \\
6.4 \\
\end{array}$ & $\begin{array}{l}10.9 \\
11.3 \\
10.6 \\
8.3 \\
7.8 \\
7.1 \\
\end{array}$ & 6.9 & $\begin{array}{l}19.1 \\
19.0\end{array}$ & 0.5 & & & \\
\hline Ata06, TD8b, G-4, 22 & $\begin{array}{l}M_{3} \\
P_{4} \\
P_{3} \\
P_{2}\end{array}$ & $d$ & $\begin{array}{l}\approx 26.1 \\
13.3 \\
11.7 \\
10.0\end{array}$ & $\begin{array}{l}\approx 26.1 \\
11.9 \\
10.4 \\
9.0\end{array}$ & $\begin{array}{l}\approx 12 \\
-- \\
7.0 \\
5.7\end{array}$ & $\begin{array}{l}-- \\
8.6 \\
8.2 \\
6.7\end{array}$ & 6.8 & & & & & \\
\hline $\begin{array}{l}\text { Ata06, TD8b, H-3, } \\
\text { colada inf., bn }\end{array}$ & $\begin{array}{l}\mathrm{P}_{4} \\
\mathrm{P}_{3}\end{array}$ & $d$ & $\begin{array}{l}13.9 \\
13.1\end{array}$ & $\begin{array}{l}12.7 \\
12.0\end{array}$ & $\overline{--}$ & $\overline{--}$ & & & & & & \\
\hline Ata06, TD8b, H-3, 21 & $\begin{array}{l}M_{2} \\
M_{1}\end{array}$ & d & $-\overline{17.1}$ & $-\overline{15.5}$ & $\begin{array}{l}11.6 \\
9.7\end{array}$ & $\begin{array}{l}-- \\
10.1\end{array}$ & & & & & & \\
\hline Ata06, TD8b, G-4, 126 & $\begin{array}{l}M_{3} \\
M_{2} \\
M_{1} \\
P_{4} \\
P_{3} \\
P_{2}\end{array}$ & $\mathrm{~s}$ & $\begin{array}{l}23.6 \\
19.6 \\
18.6 \\
13.5 \\
13.2 \\
10.9\end{array}$ & $\begin{array}{l}22.2 \\
17.9 \\
16.9 \\
12.0 \\
11.2 \\
9.8\end{array}$ & $\begin{array}{l}10.6 \\
11.4 \\
10.4 \\
8.0 \\
6.7 \\
5.4\end{array}$ & $\begin{array}{l}11.0 \\
11.6 \\
10.7 \\
8.3 \\
7.5 \\
--\end{array}$ & 6.6 & & & & & \\
\hline Ata2002, TD8b, G-7, 62 & & $\mathrm{~s}$ & & & & & & & & & & 20.0 \\
\hline
\end{tabular}


Table 14

Measurements of the incisors and canines of Dama vallonnetensis from Atapuerca TD8.

\begin{tabular}{|l|l|l|l|l|l|l|l|l|}
\hline number & tooth & s/d & DT & DMD & DLL & DTroot & DLLroot & Hli \\
\hline Ata2002, TD8b, G-13, 12 & $\mathrm{I}_{1}$ & $\mathrm{~d}$ & -- & -- & 5.5 & 5.7 & 4.8 & \\
\hline Ata2002, Tc8b, F-13, 22 & $\mathrm{I}_{1}$ & $\mathrm{~s}$ & -- & 8.8 & 6.2 & -- & - & \\
\hline Ata03, TD8b, G-3, 10 & $\mathrm{I}_{1}$ & $\mathrm{~d}$ & 11.4 & 8.4 & 6.1 & 5.0 & 4.4 & \\
\hline Ata03, TD8b, H-5, nc & $\mathrm{I}_{1}$ & $\mathrm{~d}$ & 9.5 & 7.9 & 6.5 & 5.3 & 4.8 & \\
\hline Ata05, TD8b, F-13, 1 & $\mathrm{I}_{1}$ & $\mathrm{~d}$ & 10.3 & 8.8 & -- & - & - & \\
\hline Ata06, TD8b, G-3, 74 & $\mathrm{I}_{1}$ & $\mathrm{~s}$ & 8.0 & 7.3 & 5.8 & 5.2 & 4.4 & \\
\hline Ata06, TD8b, G-4, 65 & $\mathrm{I}_{1}$ & $\mathrm{~s}$ & 10.7 & 9.3 & 6.8 & 5.7 & 4.8 & \\
\hline Ata2002, TD8b, G-10, 58 & $\mathrm{I}_{2}$ & $\mathrm{~s}$ & 6.7 & 5.1 & 5.3 & 3.3 & 4.2 & \\
\hline Ata03, TD8b, G-5, 24 & $\mathrm{I}_{2}$ & $\mathrm{~s}$ & 5.4 & 5.1 & 5.5 & 4.1 & 4.5 & \\
\hline Ata05, TD8b, H-3, 19 & $\mathrm{I}_{2}$ & $\mathrm{~d}$ & 8.1 & 6.3 & 5.5 & 4.0 & 4.9 & \\
\hline Ata05, TD8b, H-3, 414 & $\mathrm{I}_{2}$ & $\mathrm{~d}$ & 9.5 & 6.6 & 5.3 & 3.6 & 5.0 & \\
\hline Ata06, TD8b, G-3, 3 & $\mathrm{I}_{2}$ & $\mathrm{~s}$ & 8.3 & 5.8 & 6.1 & 4.6 & 3.8 & \\
\hline Ata06, TD8b, G-4, 40 & $\mathrm{I}_{2}$ & $\mathrm{~s}$ & 8.2 & 5.5 & 5.4 & 4.0 & 4.4 & \\
\hline Ata2002, TD8b, G-10, 49 & $\mathrm{C}_{\mathrm{x}}$ & $\mathrm{s}$ & 4.5 & 3.8 & 4.8 & 2.6 & 4.0 & \\
\hline Ata2002, TD8b, G-12, 17 & $\mathrm{C}_{\mathrm{x}}$ & $\mathrm{d}$ & 4.2 & 3.4 & 4.5 & 2.6 & 3.8 & \\
\hline
\end{tabular}


Table 15

Measurements of the vertebras of Dama vallonnetensis from Atapuerca TD8.

\begin{tabular}{|c|c|c|c|c|c|c|c|c|}
\hline number & vertebra & DT tooth & DTa & DTforamen ant. & DTmin & & & \\
\hline Ata2002, TD8b, G-7, 16 & axis & 24.2 & 53.5 & 20.7 & 36.9 & & & \\
\hline Ata94, TD8, t28, G-17, 16 & axis & 24.6 & 56.0 & $\geq 18.7$ & & & & \\
\hline Ata94, TD8, t29, I-16, 27 & axis & 25.2 & 59.7 & $\approx 17$ & & & & \\
\hline number & vertebra & & 4 & 13 & 15 & 19 & 20 & remarks \\
\hline Ata05, TD8b, G-13, 3 & $\mathrm{C} 2 / 4 / 5$ & $\begin{array}{l}\text { s } \\
\text { d }\end{array}$ & 24.8 & 18.9 & 18.8 & $\begin{array}{l}8.0 \\
11.4\end{array}$ & $\begin{array}{l}9.1 \\
9.4\end{array}$ & \\
\hline Ata05, TD8b, E-13, 3 & Lumbar & & & & & & & $\begin{array}{l}2 \text { specimens } \\
\text { in sediment }\end{array}$ \\
\hline Ata06, Td8b, G-3, 84 & Thoracic & & & & & & & \\
\hline Ata06, Td8b, G-3, 97 & Thoracic & & & & & & & \\
\hline Ata06, Td8b, G-3, 104 & Thoracic & & & & & & & \\
\hline
\end{tabular}


Table 16

Measurements of the scapula and humerus of Dama vallonnetensis from Atapuerca TD8.

\begin{tabular}{|c|c|c|c|c|c|c|c|c|c|}
\hline Scapula & & DAPd & DAPdf & DTd & DAPn & DTn & & & \\
\hline Ata94, TD8, t28, G-18, 2 & $d$ & -- & 37.8 & 35.0 & 28.2 & $\geq 18.3$ & & & \\
\hline Ata2002, TD8b, G-9, 31 & $\mathrm{~s}$ & -- & -- & -- & -- & -- & & & \\
\hline Ata2002, TD8b, G-9, 45 & $s$ & 49.9 & 38.8 & 35.5 & 26.6 & 17.7 & & & \\
\hline Ata2002, TD8b, G-9, 49 & $d$ & -- & -- & -- & -- & -- & & & \\
\hline Ata04, TD8b, G-5, 3 & $d$ & -- & $\geq 30.8$ & -- & 22.8 & .. & & & \\
\hline Ata06, TD8b, G-4, 95 & s & 47.4 & 38.4 & 33.0 & -- & $\geq 16.8$ & & & \\
\hline Ata06, TD8b, H-4, 14 & $d$ & 46.8 & 37.5 & 32.3 & 25.7 & 16.4 & & & \\
\hline Ata06, TD8b, G-3, 42 & $d$ & 44.1 & 35.4 & 32.8 & 23.8 & 17.2 & & & \\
\hline Ata06, TD8b, G-3, 100 & $\mathrm{~s}$ & -- & 40.2 & 37.4 & 29.8 & 20.6 & & & \\
\hline Ata06, TD8b, H-2, 22 & $d ?$ & .. & .. & $>28.4$ & .. & .. & & & \\
\hline humerus & & DAPd & DTd & DTdf & $\mathbf{R} 1$ & $\mathbf{R 2}$ & R3 & R4 & R5 \\
\hline Ata94, TD8, t28, H-16, 26 & $d$ & -- & $>40.0$ & 37.6 & 30.3 & 22.3 & 25.9 & 18.6 & 19.9 \\
\hline Ata94, TD8, t29, l-16, 46 & s & 42.8 & 42.8 & 39.3 & 30.5 & 23.8 & 27.0 & 19.3 & 19.9 \\
\hline Ata2002, TD8b, H-8, 16 & $d$ & 42.1 & 45.0 & -- & 30.9 & 22.8 & 26.5 & 18.2 & -- \\
\hline Ata2002, TD8b, G9, 27 & $d$ & -- & -- & -- & -- & 21.4 & 25.7 & 19.1 & 19.1 \\
\hline Ata2002, TD8b, F-11, 12 & $d$ & -- & -- & -- & 32.6 & 24.0 & 27.2 & -- & -- \\
\hline Ata2002, TD8b, G-14, 9 & $d$ & 46.8 & 45.0 & 42.7 & 32.7 & 24.4 & 28.7 & 21.7 & -- \\
\hline Ata2002, TD8b, G-7, 64 & $\mathrm{~s}$ & 42.9 & 42.9 & 37.4 & 29.8 & 22.8 & 26.7 & 18.6 & 19.9 \\
\hline Ata2002, TD8b, G-8, 59 & s & 43.9 & -- & 39.9 & 31.6 & 23.4 & 27.9 & 20.1 & $\geq 20.6$ \\
\hline Ata2002, Td8b, G-10, 45 & $\mathrm{~s}$ & 42.0 & .. & .. & 30.9 & .. & .. & .. & .. \\
\hline Ata2002, TD8b, G-7, 84 & $d$ & -- & 35.8 & 35.4 & 26.7 & 20.7 & 24.4 & 17.2 & 17.5 \\
\hline Ata03, TD8b, G-5, 41 & $\mathrm{~s}$ & 43.9 & 42.6 & 40.3 & 33.6 & 24.5 & 28.8 & 21.4 & 21.9 \\
\hline Ata06, TD8b, H-4, 10 & $d$ & 42.9 & 42.1 & 39.5 & 30.9 & 22.6 & 25.6 & 20.6 & 20.0 \\
\hline Ata2002, TD8b, F-9, 3 & $\mathrm{~s}$ & 40.8 & 43.0 & 38.5 & 31.3 & 22.5 & 26.1 & 18.3 & 20.1 \\
\hline
\end{tabular}


Table 17

Measurements of the radius, ulna, femur and tibia of D. vallonnetensis from Atapuerca TD8.

\begin{tabular}{|c|c|c|c|c|c|c|c|c|c|c|c|c|}
\hline Radius & & DAPp & DAPpf & DTp & DTpf & $\mathbf{L}$ & I & DAPd & DAPdf & DTd & DTdf & \\
\hline Ata2002, TD8b, G-12, 27 & $d$ & -- & - & -- & -- & -- & -- & 27.0 & 23.4 & 37.6 & 35.7 & \\
\hline Ata2002, TD8b, G-7, 31 & $d$ & 21.7 & 21.0 & $>41.7$ & 41.1 & $\gg 207$ & & juv & & & & \\
\hline Ata2002, Td8b, G-8, 3 & $d$ & & & juv & & & & $\geq 26.1$ & 20.4 & $\geq 37.5$ & 33.7 & \\
\hline Ata2002, TD8b, G-8, 25 & $d$ & -- & - & 47.1 & 41.0 & 240.4 & 230.2 & 29.4 & 23.2 & 45.0 & 37.7 & \\
\hline Ata2002, TD8b, G-12, 34 & $d$ & 22.8 & 20.8 & 41.0 & 37.9 & -- & -- & -- & -- & -- & -- & \\
\hline Ata04, TD8b, G-5, 20 & $\mathrm{~s}$ & & & & & juv & & -- & -- & 38.1 & 35.0 & \\
\hline Ata03, TD8b, G-5, 57 & & $\equiv 20.3$ & -- & -- & -- & -- & -- & -- & -- & -- & -- & \\
\hline Ata05, TD8b, E-13, 5 & $\mathrm{~s}$ & -- & -- & -- & -- & -- & -- & 24.9 & 22.7 & -- & -- & \\
\hline Ulna - prox & & DAPh & DTh & DAPn & DTn & DAPma & DTfu & DTmax & DAPmini & Lu & DAPd & DTd \\
\hline Ata2002, TD8b, F-10 & $d$ & - & -- & -- & -- & 45.3 & 12.9 & 23.3 & 27.1 & -- & & \\
\hline Ata2002, TD8b, H-8, 22 & $\mathrm{~s}$ & -- & -- & -- & -- & 40.1 & 13.9 & 21.5 & 25.3 & -- & & \\
\hline Ata2002, TD8b, F-10, 5 & $d$ & -- & -- & -- & -- & 43.8 & 13.3 & 23.7 & 26.8 & -- & & \\
\hline Ata04, TD8b, G-14, 22 & $\mathrm{~s}$ & -- & - & -- & -- & $\approx 40.7$ & 12.2 & 21.6 & 24.8 & -- & & \\
\hline Ata06, TD8b, H-3, 1 & $d$ & - & -- & -- & -- & -- & 12.0 & 23.2 & -- & -- & & \\
\hline Ata06, TD8b, H-4, 5 & $d$ & -- & - & $\geq 25.9$ & 7.9 & 32.0 & 11.6 & 19.4 & -- & -- & & \\
\hline Ata06, TD8b, H-4, 23 & & -- & - & -- & -- & -- & 14.1 & -- & -- & -- & & \\
\hline Ata06, TD8b, G-3, 27 & $d$ & -- & -- & -- & -- & -- & 14.4 & -- & -- & -- & & \\
\hline Ata94, TD8, t28, G-16, 39 & $\mathrm{~s}$ & & & juv & & & & & & & 12.6 & 11.3 \\
\hline Ata2002, TD8b, G-12, 27 & d & & & & & & & & & & 10.4 & 9.6 \\
\hline Ata2002, DT8b, H-8, 19 & $d$ & & & juv & & & & & & & 11.1 & 9.3 \\
\hline Ata04, TD8b, G-5, 23 & $d$ & & & juv & & & & & & & 10.6 & 9.7 \\
\hline Femur & & DAPpf & DTp & $\mathbf{L}$ & I & DAPd & DAPd' & DTd & DTdfp & & & \\
\hline Ata94, TD8, t29, I-17, 2 & $\mathrm{~s}$ & 28.9 & & & & & & & & & & \\
\hline Ata04, TD8b, G-5, 13 & & $\geq 28.8$ & & & & & & & & & & \\
\hline Ata03, TD8b, G-5, 22 & & & & juv & & -- & -- & -- & -- & & & \\
\hline Ata94, TD8, t28, G-16, 47 & $d$ & -- & -- & -- & -- & -- & -- & -- & -- & & & \\
\hline Tibia & & DAPp & DAPp' & DTp & DTpf & $\mathbf{L}$ & I & DAPd & DTd & DTdfa & & \\
\hline Ata94, TD8, t28, G-17, 5 & $d$ & -- & - & -- & -- & -- & -- & 29.6 & -- & -- & & \\
\hline Ata2002, TD8b, G-12, 22 & $\mathrm{~s}$ & -- & -- & -- & -- & -- & -- & 27.2 & $\geq 35.6$ & & & \\
\hline Ata2002, TD8b, G-9, 34 & $\mathrm{~s}$ & & & juv & & & & 27.9 & $\geq 34.7$ & 27.4 & & \\
\hline Ata2002, TD8b, G-7, 21 & $\mathrm{~s}$ & -- & -- & $>59.4$ & & juv & & & & & & \\
\hline Ata2002, TD8b, G-7, 34 & $d$ & -- & -- & -- & -- & -- & -- & 29.1 & $\geq 35.4$ & 27.4 & & \\
\hline Ata2002, TD8b, G-7, 50 & $\mathrm{~s}$ & & & & & juv & & 32.3 & 40.0 & 30.0 & & \\
\hline Ata2002, TD8b, G-13, 17 & $\mathrm{~s}$ & -- & -- & -- & -- & -- & - & 33.0 & 40.1 & 22.3 & & \\
\hline
\end{tabular}




\begin{tabular}{|l|l|l|l|l|l|l|l|l|l|l|l|l|}
\hline Ata2002, TD8b, F-10, 14 & d &.. &.. & -- & - & $\approx 305.3$ & 287.6 & 36.4 & 37.6 & 26.8 & & \\
\hline Ata2002, TD8b, G-7, 39 & d & - & - & - & - & - & - & 31.1 & 40.0 & 29.9 & & \\
\hline Ata94, TD8, t28, G-17, 22 & s & -- & - & -- & - & - & - & 228.1 & -- & -- & & \\
\hline Ata05, TD8b, E-12, 11 & d & -- & -- & -- & -- & - & - & 30.9 & 38.8 & 26.4 & & \\
\hline Ata06, TD8b, H-3, 32 & s & -- & -- & -- & -- & - & - & 29.6 & 38.2 & 24.3 & & \\
\hline Ata06, TD8b, H-3, 40 & s & - & -- & -- & -- & - & - & - & - & - & & \\
\hline
\end{tabular}


Table 18

Measurements of the carpals of Dama vallonnetensis from Atapuerca TD8.

\begin{tabular}{|c|c|c|c|c|c|}
\hline Scaphoid & & DAP & DT & $\mathrm{Ha}$ & \\
\hline Ata2002, TD8b, G-7, 47 & $d$ & 26.3 & 14.9 & 19.5 & \\
\hline Ata2002, TD8b, G-8, 9 & $d$ & 23.4 & 12.5 & 17.2 & \\
\hline Ata2002, TD8b, F-10, 10 & $s$ & $\geq 25.6$ & 13.5 & $\geq 19.8$ & \\
\hline Ata2002, TD8b, G-5, 40 & $d$ & 26.9 & 14.9 & 20.0 & \\
\hline Ata05, TD8b, F-13, 14 & s & $>26.1$ & 13.8 & -- & \\
\hline Ata05, TD8b, F-13, 16 & $s$ & 26.9 & 14.2 & 19.3 & \\
\hline Lunar & & DAP & $\mathrm{Ha}$ & DTp & DTd \\
\hline Ata05, TD8b, F-12, 17 & $d$ & 24.9 & 18.4 & 16.8 & 13.0 \\
\hline Ata06, TD8b, H-3, 26 & & 24.9 & 17.7 & 17.4 & 12.4 \\
\hline Ata06, TD8b, G-3, 105 & & 22.6 & 17.2 & $>15.1$ & 11.7 \\
\hline Ata06, TD8b, G-3, 16 & $d$ & $>20.5$ & 16.6 & 15.8 & 11.9 \\
\hline Ulnar & & DAP & DT & $\mathbf{H}$ & $\mathrm{Ha}$ \\
\hline Ata2002, TD8b, H-8, 20 & $d$ & 19.0 & 9.8 & 25.3 & 17.6 \\
\hline Ata05, TD8b, G-4, 47 & $d$ & 17.8 & 9.7 & $>20.0$ & 15.8 \\
\hline Ata2002, TD8b, F-11, 77 & $\mathrm{~s}$ & $>19.9$ & 14.6 & -- & -- \\
\hline Pisiform & & DAP & DTf & H & $\mathrm{Hf}$ \\
\hline Ata06, TD8b, G-3, 69 & s & 18.0 & 8.1 & 14.2 & 11.6 \\
\hline Magnum & & DAP & DT & H & h \\
\hline Ata2002, TD8b, G-7, 42 & & 21.8 & 18.9 & -- & -- \\
\hline Ata2002, TD8b, F-10, 11 & d & 22.4 & 18.5 & 14.2 & 11.5 \\
\hline Ata2002, TD8b, G-5, 2 & $\mathrm{~s}$ & 19.4 & 18.0 & 12.9 & 9.8 \\
\hline Ata05, TD8b, H-3, 5 & s & 22.9 & 21.5 & 14.4 & 11.4 \\
\hline Ata05, TD8b, F-12, 7 & s & $\geq 19.9$ & 17.9 & 14.1 & 10.8 \\
\hline Ata05, TD8b, E-12, 2 & $\mathrm{~s}$ & 21.3 & 17.2 & 14.5 & 11.2 \\
\hline Ata06, TD8b, G-3, 40 & $d$ & 20.0 & 17.4 & 13.3 & 10.1 \\
\hline Unciform & & DAP & DT & $\mathbf{H}$ & \\
\hline Ata2002, TD8b, G-5, 37 & d & 20.9 & 16.9 & 14.8 & \\
\hline Ata2002, TD8b, G-13, 5 & $d$ & -- & 15.0 & -- & \\
\hline & & & & & \\
\hline
\end{tabular}




\begin{tabular}{|l|l|l|l|l|l|}
\hline Metacarpal II & & DAPp & DTp & L & \\
\hline Ata04, TD8b, G-5, 38 & S & 6.4 & 3.9 & - & \\
\hline
\end{tabular}


Table 19

Measurements of some of the maleolar, navicocuboid and cuneiform of Dama vallonnetensis from Atapuerca TD8.




Table 20

Measurements of the calcaneum and astragalus of Dama vallonnetensis from Atapuerca TD8.

\begin{tabular}{|c|c|c|c|c|c|c|c|c|c|c|c|}
\hline Calcaneum & & DAPh & DTh & DAPn & DTn & DAPsf & DTfs & DAPm & $\mathbf{L}$ & Lu & LI \\
\hline Ata2002, TD8b, G-8, 80 & $d$ & 26.8 & 21.1 & 25.8 & 11.4 & 30.2 & 24.5 & 32.2 & -- & 66.8 & -- \\
\hline Ata2002, TD8b, G-8, 35 & $\mathrm{~s}$ & -- & -- & -- & 10.7 & 27.0 & 23.8 & & 91.5 & 61.8 & 34.5 \\
\hline Ata2002, TD8b, G-7, 92 & $\mathrm{~s}$ & -- & -- & 25.2 & 10.6 & 27.4 & -- & 30.5 & -- & -- & 34.1 \\
\hline Ata04, TD8b, G-6, 10 & & juv & & 16.2 & 10.6 & 21.7 & 21.6 & -- & -- & -- & -- \\
\hline Ata04, TD8b, G-6, removido & & $>22.5$ & 20.0 & juv & & & & & & & \\
\hline Ata04, TD8b, G-5, 22 & $\mathrm{~s}$ & 22.8 & 18.7 & 21.1 & 12.5 & 26.2 & 24.3 & 30.4 & -- & 57.3 & -- \\
\hline Ata05, TD8b, G-3, 8 & $d$ & -- & -- & -- & 13.0 & -- & -- & -- & $>93.4$ & $>63.0$ & 34.8 \\
\hline Ata05, TD8b, G-3, 2 & $\mathrm{~s}$ & 25.4 & 20.9 & juv & & & & & & & \\
\hline Ata05, TD8b, F-12, 22 & $d$ & -- & 19.8 & -- & -- & -- & -- & -- & -- & -- & -- \\
\hline Ata05, TD8b, F-12, 5 & $\mathrm{~s}$ & 26.9 & 22.1 & 26.6 & 11.7 & 31.4 & -- & 36.6 & 92.6 & 63.4 & 34.1 \\
\hline Ata06, TD8b, H-3, 11 & $\mathrm{~s}$ & $\approx 25.9$ & -- & 22.9 & 10.8 & 28.0 & 24.2 & 32.9 & $>87.7$ & $>58.4$ & 33.1 \\
\hline Ata02, TD8b, G-7, 75 & d & $>22.8$ & $\geq 20.5$ & 22.9 & 11.0 & -- & -- & $>29.6$ & 89.0 & -- & -- \\
\hline Astragalus & & Lext & $\mathrm{Lm}$ & Lint & DTp & DTp' & DTd & & & & \\
\hline Ata2002, TD8b, G-9, 39 & $\mathrm{~s}$ & 39.4 & 33.0 & 42.3 & 27.0 & 24.0 & 27.6 & & & & \\
\hline Ata2002, TD8b, G-7, 103 & $\mathrm{~s}$ & 36.6 & 29.1 & 34.4 & 23.9 & 21.7 & 23.0 & & & & \\
\hline Ata2002, TD8b, G-9, 17 & $\mathrm{~s}$ & 41.5 & .. & 38.7 & 26.6 & 23.8 & 26.0 & & & & \\
\hline Ata94, TD8, t28, H-16, 39 & $d$ & 39.2 & $<33.4$ & -- & 25.7 & 22.8 & 24.9 & & & & \\
\hline Ata94, TD8, t28, H-16, 39 & $d$ & 39.3 & 32.2 & -- & 25.7 & 24.5 & $\geq 24.9$ & & & & \\
\hline Ata2002, TD8b, F-12, 59 & $\mathrm{~s}$ & $>44.3$ & 35.2 & $>40.7$ & 28.2 & 25.5 & -- & & & & \\
\hline Ata03, TD8b, G-5, 27 & $\mathrm{~s}$ & 44.2 & 36.3 & 40.9 & 28.0 & 24.9 & 27.7 & & & & \\
\hline Ata05, TD8b, H-3, 18 & $d$ & 41.6 & 32.5 & 38.2 & 25.6 & 22.8 & 24.4 & & & & \\
\hline Ata06, TD8b, G-4, 128 & $\mathrm{~s}$ & -- & 36.9 & 42.9 & 29.1 & 26.2 & 29.9 & & & & \\
\hline Ata06, TD8b, H-4, 9 & $d$ & 41.9 & .. & 39.6 & 27.2 & 24.4 & 26.6 & & & & \\
\hline Ata06, TD8b, G-3, 5 & $\mathrm{~s}$ & 41.7 & 33.2 & 37.9 & 27.6 & 25.2 & 26.7 & & & & \\
\hline Ata02, TD8b, G-17, 97 & $\mathrm{~s}$ & -- & -- & -- & 24.7 & 22.2 & -- & & & & \\
\hline
\end{tabular}


Table 21 Measurements of the metacarpals of Dama vallonnetensis from Atapuerca TD8. **) estimated value.

\begin{tabular}{|c|c|c|c|c|c|c|c|c|c|c|c|c|c|c|c|}
\hline Metacarpal (Mc III+IV) & & DAPp & DTp & DAPpf & DTpf & DAPmini & DTmini & DTdf & DAP III & $\mathrm{DT}_{\mathrm{III}}$ & DAP $_{\text {IV }}$ & $\mathrm{DT}_{\mathrm{IV}}$ & $\mathrm{L}$ & $\mathrm{L}_{\mathrm{III}}$ & $\mathrm{L}_{\mathrm{IV}}$ \\
\hline Ata94, TD8, t28, G-16, 34 & s & -- & -- & - & -- & -- & - & -- & 23.1 & 15.8 & -- & -- & -- & -- & -- \\
\hline Ata94, TD8, t28, H-16, 36 & $\mathrm{~s}$ & -- & - & -- & -- & -- & - & - & -- & 15.5 & 221.9 & 14.6 & & & \\
\hline Ata2002, TD8b, G-10, 39 & $?$ & -- & -- & -- & - & -- & -- & -- & 22.5 & 15.0 & 23.7 & -- & - & - & -- \\
\hline Ata2002, TD8b, G-9, 39 & s & 24.5 & 34.9 & 22.2 & 31.3 & 18.5 & 20.5 & juv & & & & & & & \\
\hline Ata2002, TD8b, G-9, 29 & $\mathrm{~s}$ & $\approx 23$ & $\approx 31.8$ & .. & .. & -- & - & - & -- & - & - & - & - & -- & - \\
\hline Ata2002, TD8b, G-10, 3 & $d$ & $\approx 24.1$ & 32.3 & $\approx 20.8$ & 29.1 & -- & -- & -- & -- & -- & - & -- & -- & - & - \\
\hline Ata2002, TD8bG-8, 39+55 & s & 23.0 & 30.6 & 14.6 & 28.2 & 14.1 & $\leq 20.9$ & 29.5 & 21.2 & 13.2 & 21.3 & 14.2 & 219.1 & 212.7 & 214.0 \\
\hline Ata2002, TD8bG10, 51+52 & d & 24.6 & 33.5 & 22.4 & 30.0 & $<19.3$ & 20.0 & -- & - & - & -- & -- & - & - & - \\
\hline Ata2002, Td8b, G-10, 57 & $?$ & -- & -- & -- & -- & -- & - & 33.5 & 23.0 & 15.5 & 22.8 & 15.6 & -- & -- & -- \\
\hline Ata2002, Td8b, G-9, 39 & s & 24.3 & 37.7 & 21.8 & 34.4 & 18.0 & 20.4 & -- & -- & -- & -- & -- & -- & - & -- \\
\hline Ata2002, TD8b, G-8, 62 & d & -- & -- & -- & -- & 15.8 & -- & $32,9^{* *}$ & -- & -- & 23.9 & 15.1 & 235 & $\approx 228$ & 230.7 \\
\hline Ata04, TD8b, G-4, 2 & d & - & -- & -- & -- & 14.0 & -- & 31.1 & 21.8 & 15.0 & 22.0 & 14.4 & - & - & -- \\
\hline Ata04, Td8b, G-6, 27 & s & $\geq 19.6$ & 28.1 & 19.6 & 27.1 & - & -- & - & - & -- & -- & -- & -- & - & -- \\
\hline Ata04, TD8b, G-5, 99 & $\mathrm{~s}$ &. & 36.4 & & 35.4 & & 22.6 & 35.4 & .. & .. & & & 248.9 & 244.3 & 244.2 \\
\hline Ata03, TD8b, G-3, 18 & $d$ & 22.9 & 31.7 & 20.3 & 29.8 & - & -- & -- & -- & - & - & -- & -- & - & -- \\
\hline Ata200TD8b, G-8, 89 & $\mathrm{~s}$ & -- & 29.0 & -- & -- & 15.2 & \begin{tabular}{|l|}
17.7 \\
\end{tabular} & 31.2 & $\geq 21.6$ & -- & $>21.2$ & 14.6 & 225.7 & 223.0 & 222.1 \\
\hline Ata03, TD8b, G-6, 31 & s? & -- & -- & -- & -- & -- & - & 32.7 & 21.8 & 15.5 & 21.8 & 15.7 & -- & -- & -- \\
\hline Ata05, TD8b, H-2, 3 & & - & - & - & - & -- & $\leq 20.6$ & - & - & -- & - & - & -- & - & -- \\
\hline Ata06, TD8b, G-4, 82 & s & -- & -- & - & -- & 16.3 & 19.5 & 31.5 & 21.7 & 14.7 & 21.9 & 14.8 & $>227$ & -- & - \\
\hline Ata06, TD8b, H-3, 43 & d & juv & & & & 15.3 & & 32.5 & 22.2 & 15.0 & 21.7 & $\approx 14.2$ & & & \\
\hline
\end{tabular}




\begin{tabular}{|l|l|l|l|l|l|l|l|l|l|l|l|l|l|l|l|}
\hline Ata06, TD8b, G-3, 115 & - & - & - & - & - & - & - & 29.1 & 20.4 & 13.3 & 20.7 & 13.2 & - & - & - \\
\hline Ata06, TD8b, G-3, 113 & d & - & - & - & - & 15.2 & 19.3 & 31.9 & 32.8 & 15.2 & - & 215.2 & - & - & - \\
\hline Ata2002, TD8b, G-10,4 & d & - & - & - & - & 15.2 & - & -32 & 22.1 & 15.1 & - & - & - & - \\
\hline
\end{tabular}


Table 22

Measurements of the metatarsals of Dama vallonnetensis from Atapuerca TD8.

\begin{tabular}{|c|c|c|c|c|c|c|c|c|c|c|c|c|c|c|c|}
\hline Metatarsal (Mt III+IV) & & DAPp & DTp & DAPpf & DTpf & DAPmini & DTmini & DTdf & DAP $_{\text {III }}$ & $\mathrm{DT}_{\text {IIII }}$ & DAP $_{\text {IV }}$ & $\mathrm{DT}_{\mathrm{IV}}$ & $\mathbf{L}$ & $\mathrm{L}_{\mathrm{III}}$ & $\mathrm{L}_{\mathrm{IV}}$ \\
\hline Ata94, TD8, t29, H-16, 56 & $\mathrm{~s}$ & $\approx 34.0$ & $\approx 27.9$ & $\approx 28.9$ & -- & $\leq 19.3$ & 18.1 & -- & -- & -- & -- & -- & -- & -- & -- \\
\hline Ata94, t28, G-17, 5 & $\mathrm{~s}$ & -- & -- & -- & -- & 17.4 & 18.5 & & juv & & juv & & & & \\
\hline Ata94, TD8, t28, G-17, 5 &.. & -- & -- & -- & -- & -- & -- & -- & - & - & -- & -- & -- & -- & -- \\
\hline Ata2002, TD8b, $\mathrm{H}-8,7$ & $d$ & -- & -- & -- & -- & -- & -- & 33.3 & 22.7 & 15.4 & 22.5 & 15.4 & -- & -- & -- \\
\hline Ata2002, TD8b, G-9, 8 & $\mathrm{~s}$ & -- & - & -- & -- & -- & - & - & juv & & juv & & & & \\
\hline Ata2002, TD8b, G-10, 3 & $\mathrm{~s}$ & -- & - & -- & -- & $\leq 17.7$ & $\leq 18.6$ & - & -- & -- & - & -- & -- & -- & - \\
\hline Ata2002, TD8b, G-8, 29 & $\mathrm{~d}$ & 31.9 & 29.2 & 27.6 & 26.9 & - & -- & -- & -- & -- & -- & -- & -- & -- & -- \\
\hline Ata2002, TD8b, G-8, 37 & $d$ & -- & -- & -- & -- & -- & -- & -- & -- & 15.4 & 20.1 & 15.7 & -- & -- & -- \\
\hline Ata06, TD8b, G-4, 144 & .. & -- & -- & - & -- & -- & -- & 36.0 & 25.3 & 16.2 & 24.9 & 17.1 & -- & -- & -- \\
\hline Ata06, TD8b, G-13, 1 & $d$ & -- & -- & -- & -- & $\leq 17.3$ & 18.3 & -- & -- & -- & -- & -- & -- & -- & -- \\
\hline Ata06, TD8b, G-3, 109 & $\mathrm{~s}$ & 33.6 & 28.8 & 29.3 & 26.6 & 16.8 & 18.3 & & juv & & juv & & & & \\
\hline
\end{tabular}


Table 23

Measurements of the distal articulations of the metapodials of Dama vallonnetensis from Atapuerca TD8 (* = juvenile).

\begin{tabular}{|l|l|l|l|}
\hline Metapodial (Mc/MT) & & DAP $_{\text {IIIII }}$ & DT $_{\text {IIIII }}$ \\
\hline Ata94, TD8, t29, I-16, 34 & $\mathrm{I}$ & $>21.6$ & $\geq 15.5$ \\
\hline Ata94, TD8, t29, l-16, sc & $\mathrm{I}$ & 22.7 & 14.8 \\
\hline Ata94, TD8, t29, I-16, sc & $\mathrm{r}$ & 22.5 & 14.5 \\
\hline Ata2002, TD8b, G-9, 7 & $\mathrm{r}$ & 220.9 & 14.2 \\
\hline Ata2002, TD8b, G-9, 5 & $\mathrm{I}$ & 20.8 & 14.8 \\
\hline Ata2002, TD8b, G-8, 40* & $\mathrm{I}$ & 22.8 & 15.6 \\
\hline Ata2002, TD8b, G-8, 40* & $\mathrm{r}$ & 22.8 & 15.2 \\
\hline Ata94, TD8, t29, l-16, sc & $\mathrm{I}$ & 22.7 & 14.8 \\
\hline Ata94, TD8, t29, I-16, sc & $\mathrm{r}$ & 22.5 & 14.4 \\
\hline Ata03, TD8b, G-5, 28* & $\mathrm{r}$ & 23.1 & 15.2 \\
\hline Ata06,TD8b, H-3, 31* & $\mathrm{r}$ & 20.5 & 14.1 \\
\hline
\end{tabular}


Table 24

Measurements of the first phalanges of Dama vallonnetensis from Atapuerca TD8.

\begin{tabular}{|c|c|c|c|c|c|c|c|}
\hline Phalanx III/IV-1 & & DAPp & DAPpf & DTp & $\mathbf{L}$ & DAPd & DTd \\
\hline Ata94, TD8 base, I-17, sc & r & 23.0 & 21.7 & 16.8 & -- & -- & -- \\
\hline Ata94, TD8, t28, G-17, 17 & 1 & 22.0 & 20.2 & 17.7 & 48.8 & 14.3 & 14.7 \\
\hline Ata2002, TD8b, G-7, 78 & 1 & 23.9 & 21.6 & 17.2 & $\geq 54.3$ & -- & -- \\
\hline Ata2002, TD8b, G-8, 61 & $r$ & 23.7 & 23.5 & 16.8 & 53.9 & 15.6 & 15.4 \\
\hline Ata2002, TD8b, G-8, 38 & r & 22.2 & 22.2 & 16.4 & -- & - & 14.9 \\
\hline Ata2002, TD8b, G-8, 61 & $r$ & 23.6 & 22.0 & 19.1 & 53.9 & 15.8 & 15.4 \\
\hline Ata2002, TD8b, H-8, 21 & 1 & 20.3 & 18.7 & 14.6 & 48.8 & 13.6 & 14.1 \\
\hline Ata2002, TD8b, G-7, 27 & r & 20.6 & 19.3 & 16.3 & -- & -- & -- \\
\hline Ata2002, TD8b, F-13, 23 & $r$ & -- & -- & $>>15$ & $>52.1$ & $\geq 14.7$ & -- \\
\hline Ata94, TD8, t29, H-16, 58A & 1 & 18.9 & 18.6 & 15.1 & 48.2 & 13.6 & 13.6 \\
\hline Ata04, TD8b, G-14, 21 & 1 & 23.9 & 22.9 & 17.9 & 54.2 & 15.2 & 15.1 \\
\hline Ata04, TD8b, G-5, 47 & I & 23.3 & 22.3 & 17.0 & 51.2 & 15.4 & 15.3 \\
\hline Ata04, TD8b, G-5, 12 & r & 23.4 & 22.8 & 17.5 & 54.8 & 14.7 & 15.8 \\
\hline Ata04, TD8b, G-14, 25 & .. & -- & -- & -- & -- & -- & -- \\
\hline Ata04, TD8b, G-5, 43 & 1 & 19.5 & 17.6 & 14.2 & 45.2 & 12.5 & 12.9 \\
\hline Ata04, TD8b, G-5,16 & $r$ & 22.3 & 20.5 & 17.1 & 49.2 & $>14.4$ & $>15.2$ \\
\hline Ata04, TD8b, G-5, 70 & I & $\geq 19.8$ & $\geq 17.1$ & 15.8 & 46.8 & 13.2 & 13.9 \\
\hline Ata04, TD8b, G-14, 15 & r & -- & -- & 16.3 & $>48.4$ & -- & 14.3 \\
\hline Ata03, TD8b, G-3, 14 & I & -- & -- & -- & -- & 13.6 & 14.4 \\
\hline Ata03, TD8b, G-5, 52 & $r$ & 23.9 & 21.8 & 17.6 & 50.8 & 15.0 & 15.5 \\
\hline Ata03, TD8b, G-6, 52 & 1 & -- & $\approx 20.1$ & 17.1 & -- & -- & -- \\
\hline Ata03, TD8b, G-15, 3 & I & 21.9 & 20.3 & 17.4 & 51.2 & 14.0 & 15.1 \\
\hline Ata03, TD8b, G15, 6 & I & 23.7 & 22.9 & 17.5 & 53.9 & 15.1 & 15.1 \\
\hline Ata03, TD8b,G-5, bn & 1 & -- & -- & -- & -- & 14.6 & 15.7 \\
\hline Ata05, TD8b, H-3, 15 & $r$ & 21.5 & 19.0 & 15.6 & 51.2 & 13.9 & 14.9 \\
\hline Ata05, TD8b, H-3, 24 & 1 & -- & -- & -- & $>46.5$ & 13.9 & 14.4 \\
\hline Ata05, TD8b, G-3, 10 & $r$ & 19.9 & 19.2 & 15.2 & 47.0 & 13.9 & 14.2 \\
\hline Ata05, TD8b, G-4, 2 & I & 19.7 & 18.6 & 15.9 & 48.8 & 13.6 & 14.0 \\
\hline Ata05, TD8b, H-3, 36 & $r$ & $\geq 22.0$ & $\geq 19.4$ & 16.3 & 48.0 & 13.6 & 14.4 \\
\hline Ata06, TD8b, G-4, 116 & 1 & -- & -- & -- & -- & $\approx 17$ & $\geq 12.7$ \\
\hline Ata06, TD8b, G-3, 34 & $r$ & 21.9 & 20.6 & 16.5 & $48.9 ?$ & 14.1 & 14.7 \\
\hline Ata06, TD8b, H-3, 19 & $r$ & 21.6 & 20.3 & 12.4 & 51.0 & 15.0 & 15.4 \\
\hline Ata06, TD8b, H-3, colada inf., bn & 1 & -- & -- & -- & -- & 14.9 & 15.2 \\
\hline
\end{tabular}




\begin{tabular}{|l|l|l|l|l|l|l|l|}
\hline Ata06, TD8b, H-4, 3 & $\mathrm{r}$ & 21.6 & 21.1 & 16.6 & 45.4 & 14.0 & 13.9 \\
\hline Ata06, TD8b, H-4, 15 & $\mathrm{r}$ & 20.7 & 18.5 & 17.0 & 51.5 & 14.9 & 15.1 \\
\hline Ata06, TD8b, H-4, 11 & $\mathrm{I}$ & 21.5 & 19.5 & 16.3 & -- & 13.6 & 14.1 \\
\hline
\end{tabular}


Table 25

Measurements of the second phalanges of Dama vallonnetensis from Atapuerca TD8.

\begin{tabular}{|c|c|c|c|c|c|c|}
\hline Phalanx III/IV-2 & & DAPp & DTp & $\mathbf{L}$ & DAPd & DTd \\
\hline Ata94, TD8, t28, G-18, 2 & $\mathrm{r}$ & 23.4 & 17.5 & -- & -- & -- \\
\hline Ata94, TD8, t28, G-16, 38 & $\mathrm{r}$ & 21.0 & 16.1 & 34.6 & 18.8 & 12.6 \\
\hline Ata94, TD8, t28, G-17, 25 & $r$ & 20.6 & 15.8 & 34.1 & 18.6 & $\geq 12.7$ \\
\hline Ata2002, TD8b, G-12, 39 & 1 & 20.7 & -- & 37.9 & 19.2 & 14.2 \\
\hline Ata2002, TD8b, G-7, 45 & $\mathrm{r}$ & 21.1 & 16.2 & -- & -- & $>12.3$ \\
\hline Ata2002, TD8b, H-8, 1 & $r$ & 22.4 & 17.1 & 37.9 & 18.5 & 13.3 \\
\hline Ata2002, TD8b, F-12, 58 & I & 22.2 & 16.6 & 37.1 & 18.1 & 13.1 \\
\hline Ata2002, TD8b, G-7, 45 & $r$ & 20.6 & 16.2 & -- & -- & 12.9 \\
\hline Ata2002, TD8b, G-7, 96 & $\mathrm{r}$ & -- & $\approx 15.7$ & 33.6 & 19.9 & 13.2 \\
\hline Ata04, TD8b, G-5, 67 & 1 & 22.0 & 16.7 & 37.3 & 18.6 & 13.5 \\
\hline Ata04, TD8b, G-5, 32 & 1 & 19.9 & 14.4 & 34.4 & 16.6 & 11.3 \\
\hline Ata04, TD8b, G-14, 13 & $r$ & 21.5 & 16.3 & 36.1 & $\geq 16.9$ & $\geq 12.3$ \\
\hline Ata04, TD8b, G-5, 68 & $\mathrm{r}$ & $>21.0$ & 17.2 & 33.8 & 18.9 & 12.8 \\
\hline Ata03, TD8b, G-4, 23 & $r$ & 19.0 & 14.9 & 31.8 & 17.4 & 11.8 \\
\hline Ata03, TD8b, G-6, 24 & $r$ & -- & $\geq 16.7$ & -- & 17.9 & 12.9 \\
\hline Ata03, TD8b, G-5, 34 & $r$ & 22.6 & 16.9 & 38.7 & 18.1 & 17.9 \\
\hline Ata03, TD8b, G-5, bn & $\mathrm{r}$ & -- & - & -- & 18.7 & $\geq 12.4$ \\
\hline Ata05, TD8b, F-13, 2 & $r$ & 33.2 & 24.9 & 49.5 & 30.4 & 22.1 \\
\hline Ata05, TD8b, H-3, 7 & $r$ & $\geq 22.1$ & 16.5 & 34.2 & 17.2 & 12.3 \\
\hline Ata05, TD8b, H-3, 8 & $r$ & 21.9 & 17.2 & 34.5 & 17.5 & 12.3 \\
\hline Ata05, TD8b, H-3, 4 & $r$ & 21.6 & 16.1 & 34.8 & 17.1 & 12.2 \\
\hline Ata05, TD8b, E-12, 13 & $r$ & -- & 14.9 & $\geq 28.9$ & $\approx 17$ & -- \\
\hline Ata06, TD8b, G-4, 2 & 1 & 22.0 & 17.0 & 36.5 & 19.0 & 13.3 \\
\hline Ata06, TD8b, G-4, 86 & 1 & 18.4 & 14.9 & 30.7 & 18.0 & 12.0 \\
\hline Ata06, TD8b, G-4, 23 & $r$ & 20.7 & 16.2 & $\geq 33.4$ & 19.6 & $\geq 12.8$ \\
\hline Ata06, TD8b, G-4, 143 & $r$ & -- & 16.7 & 37.2 & -- & -- \\
\hline Ata06, TD8b, G-4, 28 & 1 & 19.7 & 15.2 & $>34.0$ & 17.1 & 12.4 \\
\hline Ata06, TD8b, G-4, 30 & $\mathrm{r}$ & 19.6 & 16.0 & 33.4 & 18.2 & 12.1 \\
\hline Ata06, TD8b, G-4, 46 & 1 & -- & -- & -- & $\approx 17$ & $\geq 12.7$ \\
\hline Ata06, TD8b, G-3, 6 & $r$ & 22.2 & 17.6 & 37.6 & 17.9 & $>13.3$ \\
\hline Ata06, TD8b, G-3, 107 & $\mathrm{r}$ & $>23.4$ & 19.3 & $\geq 39.4$ & 19.7 & 14.2 \\
\hline Ata06, TD8b, G-3, 91 & I & -- & -- & -- & -- & -- \\
\hline
\end{tabular}




\begin{tabular}{|l|l|l|l|l|l|l|}
\hline Phalanx II/V-2 & & DAPp & DTp & L & DAPd & DTd \\
\hline Ata06, TD8b, G-3, 99 & I & 7.8 & 4.0 & 9.2 & 7.3 & 3.5 \\
\hline
\end{tabular}


Table 26

Measurements of the third phalanges of Dama vallonnetensis from Atapuerca TD8.

\begin{tabular}{|c|c|c|c|c|c|}
\hline Phalanx III/IV-3 & & DAPp & DAPp' & DTp & L \\
\hline Ata94, TD8, t28, H-16, 36 & $r$ & 23.2 & 20.5 & 12.7 & 34.3 \\
\hline Ata2002, TD8b, G-12, 39 & 1 & 20.8 & 18.8 & 12.5 & 37.5 \\
\hline Ata2002, TD8b, G-8, 82 & .. & -- & -- & $\geq 13.3$ & 39.1 \\
\hline Ata2002, TD8b, G-9, 58 & 1 & 22.4 & 19.9 & 13.9 & 36.5 \\
\hline Ata2002, TD8b, G-8, 26 & I & 23.2 & 18.9 & 15.0 & -- \\
\hline Ata04, TD8b, G-14, 27 & $r$ & -- & -- & $>11.6$ & $>34.9$ \\
\hline Ata04, TD8b, G-6, 13 & 1 & 22.6 & 21.9 & 17.3 & $>35.5$ \\
\hline Ata04, TD8b, F-14, 22 & $r$ & 21.4 & 19.6 & 13.1 & 36.1 \\
\hline Ata03, TD8b, G-5, 12 & 1 & 21.6 & 19.9 & 13.2 & 37.1 \\
\hline Ata05, TD8b, H-3, 16 & $r$ & -- & -- & 14.1 & 35.1 \\
\hline Ata05, TD8b, H-3, 37 & 1 & 22.5 & 18.9 & 15.1 & 38.2 \\
\hline Ata05, TD8b, H-3, 21 & $r$ & 22.3 & 18.8 & 13.7 & 37.4 \\
\hline Ata05, TD8b, G-13, 1 & $r$ & 22.8 & 20.8 & 13.6 & 33.2 \\
\hline Ata05, TD8b, F-13, 9 & $r$ & 22.7 & 19.5 & 12.6 & -- \\
\hline Ata06, TD8b, G-4, 101 & $r$ & 22.4 & 19.8 & 12.9 & 35.4 \\
\hline Ata06, TD8b, G-4, 132 & 1 & 23.2 & 21.7 & 13.9 & 34.2 \\
\hline Ata06, TD8b, H-3, 6 & 1 & 21.7 & 18.8 & 12.2 & 35.7 \\
\hline Ata06, TD8b, H-3, 4 & $\mathrm{r}$ & 23.1 & 21.7 & 14.3 & 39.4 \\
\hline Ata06, TD8b, H-3, 25 & $r$ & 24.9 & 22.7 & 14.4 & -- \\
\hline Ata06, TD8b, H-3, 36 & $r$ & 25.0 & 21.1 & 14.0 & 39.6 \\
\hline Ata06, TD8b, G-3, 46 & 1 & 23.3 & 20.2 & 13.3 & 38.9 \\
\hline Ata06, TD8b, G-3, 22 & 1 & 23.1 & 21.0 & 14.7 & 38.9 \\
\hline
\end{tabular}


Table 27

Measurements of the sesamoids of Dama vallonnetensis from Atapuerca TD8.

\begin{tabular}{|l|l|l|l|l|l|l|}
\hline Sesamoid behind Phalanx 1 & & & L & DT & DAP & DAP' \\
\hline Ata04, Td8b, G-5, 58 & I & axial & 17.0 & 7.4 & 9.6 & 8.0 \\
\hline Ata04, TD8b, G-5, 87 & I & axial & 18.7 & 8.7 & 11.0 & 8.5 \\
\hline Ata04, TD8b, G-6, removido & I & axial & 15.8 & 7.6 & 8.9 & 7.7 \\
\hline Ata04, Td8b, G-5, 34 & I & axial & 15.6 & 17.4 & 8.4 & 6.6 \\
\hline Ata04, TD8b, G-5, 35 & r & abaxial & 14.4 & 7.0 & 11.2 & 10.8 \\
\hline Ata05, TD8b, G-13, 9 & I & axial & 18.2 & 9.0 & 10.8 & 8.4 \\
\hline Ata05, TD8b, F-13, 13 & r & axial & 16.1 & 6.8 & 8.9 & 7.8 \\
\hline Ata05, TD8b, F-12, 11 & I & axial & $>16.6$ & 8.0 & $>9.7$ & $>8.6$ \\
\hline Ata06, TD8b, G-4, 129 & I & abaxial & -- & 7.1 & $>11.9$ &.. \\
\hline Ata06, TD8b, G-4, 11 & r & axial & 17.9 & 7.9 & 9.4 & 7.8 \\
\hline Ata06, TD8b, G-4, 108 & I & axial & 16.4 & 7.8 & 9.0 & 7.7 \\
\hline Ata06, TD8b, G-4, 133 & I & axial & 17.9 & 8.5 & 9.3 & 8.0 \\
\hline Ata06, TD8b, H-4, 7 & r & abaxial & 13.7 & 6.9 & 11.3 & 10.5 \\
\hline Ata04, TD8b, G-5, 36 & I & abaxial & 14.2 & 6.5 & 11.5 & 11.1 \\
\hline & & & & & & \\
\hline Sesamoid behind Phalanx 3 & & L & DT & DAP & & \\
\hline Ata06, Td8b, G-3, 25 & I & 5.6 & 10.8 & 4.5 & & \\
\hline
\end{tabular}


Table 28

Measurements of the teeth of Bison voigtstedtensis from Atapuerca TD8.

\begin{tabular}{|c|c|c|c|c|c|c|c|c|c|}
\hline upper cheek teeth & & & DAP & $\mathrm{DAPb}$ & DTa & DTp & DTpp & $\mathrm{Ha}$ & $\mathrm{Ta}$ \\
\hline Ata2002, TD8b, G-9, 42 & $M^{3}$ & $\mathrm{~s}$ & 31.5 & -- & -- & -- & & & \\
\hline Ata2002, TD8b, G-7, 90 & $M^{3}$ & $d$ & 31.9 & 29.6 & 26.1 & 23.9 & & $>54.8$ & \\
\hline Ata2002, TD8b, F-11, 69 & $M^{2}$ & $\mathrm{~s}$ & $\geq 32.8$ & $\geq 31.0$ & 28.4 & 28.0 & & & \\
\hline Ata94, TD8, t29, I-16, 55 & $M^{1 / 2}$ & $\mathrm{~s}$ & 21.2 & 20.5 & 23.6 & 25.2 & & & \\
\hline Ata94, TD8, t29, I-16, 24 & $M^{1 / 2}$ &.. & -- & -- & -- & -- & & & \\
\hline Ata06, Td8b, G-3, 4 & $M^{1 / 2}$ & $\mathrm{~s}$ & 30.4 & 26.4 & 27.0 & 26.6 & & & \\
\hline Ata94, TD8, t29, I-16, 23 & $M / D^{x}$ & $d$ & -- & -- & -- & -- & & & \\
\hline Ata2002, TD8b, B-8, 21 & $M^{1 / 2}$ & $d$ & 34.3 & 30.3 & 28.0 & 28.0 & & $>>56$ & \\
\hline \multirow[t]{3}{*}{ Ata2002, TD8b, F-12, 31} & $M^{2}$ & \multirow[t]{3}{*}{ s } & 29.6 & 27.9 & 27.4 & 27.8 & & & \\
\hline & $M^{1}$ & & 22.0 & 21.4 & 24.0 & 26.1 & & & \\
\hline & $P^{4}$ & & 18.9 & 16.5 & & 20.4 & & & \\
\hline Ata2002, TD8b, G-8, 28 & $\mathrm{P}^{4}$ & $d$ & 18.8 & 15.8 & & 20.3 & & & \\
\hline Ata2002, Td8b, G-8, 72 & $P^{2}$ & $d$ & 18.3 & 17.8 & 14.1 & -- & & & \\
\hline Ata06, TD8b, H-3, 27 & $D^{3 / 4}$ & $\mathrm{~s}$ & 28.6 & 23.4 & -- & -- & & & \\
\hline Ata04, TD8b, H-6, 6 & $D^{3}$ & $d$ & -- & -- & 13.4 & -- & & & \\
\hline Ata2002, TD8b, F-11, 23 & $D^{3}$ & $d$ & 28.6 & 22.3 & 14.6 & 18.3 & & & \\
\hline Ata2002, TD8b, G-9, 20 & $D^{3}$ & $\mathrm{~s}$ & -- & -- & -- & 17.5 & & & \\
\hline Ata2002, Td8b, F-12, 13 & $D^{2}$ & $d$ & 15.9 & $\geq 15.0$ & -- & 12.4 & & & \\
\hline lower cheek teeth & & & DAP & DAPb & DTa & DTp & DTpp & Ha & $\mathrm{Ta}$ \\
\hline Ata2002, TD8b, G-14, 2 & $M_{3}$ & $d$ & 44.1 & 42.8 & 18.0 & 16.1 & 10.3 & & 0.9 \\
\hline Ata94, TD8, t2 & $M_{1 / 2}$ & $\mathrm{~s}$ & 22.3 & 21.9 & 15.9 & 18.7 & & & 1.0 \\
\hline Ata94, TD8, t27, G-17, 1 & $M_{1 / 2}$ & $d$ & $\geq 30.5$ & $\approx 26.9$ & $\approx 16.2$ & $\approx 15.8$ & & & \\
\hline Ata2002, TD8b, F-12, 16 & $M_{1 / 2}$ & $d$ & 29.9 & 26.0 & 16.6 & 17.8 & & & 1.0 \\
\hline Ata2002, Td8b, G-14, 2 & $M_{x}$ & $d$ & - & -- & -- & -- & & & \\
\hline Ata02, TD8b, F-12, 55 & $M_{1 / 2}$ & $\mathrm{~s}$ & 30.6 & - & -- & -- & & & \\
\hline Ata2002, tD8b, F-12, 28 & $\mathrm{P}_{3}$ & $d$ & 20.6 & 18.5 & 9.9 & 11.8 & & & \\
\hline Ata05, TD8b, G-8, 1 & $\mathrm{P}_{2}$ & $\mathrm{~s}$ & 11.8 & 10.7 & 8.2 & 9.2 & & & \\
\hline Ata2002, TD8b, G-11, 23 & $\mathrm{D}_{4} ?$ & $?$ & -- & -- & -- & -- & -- & & \\
\hline incisors & & & DT & DMD & DLL & Hli & DTroot & DLLroot & \\
\hline Ata04, Td8b, G-5, 9 & $\mathrm{I}_{1}$ & $\mathrm{~s}$ & 15.7 & 15.0 & 10.4 & 21.1 & & & \\
\hline
\end{tabular}




\begin{tabular}{|l|l|l|l|l|l|l|l|l|l|}
\hline Ata2002, TD8b, G-9, 1 & $\mathrm{I}_{2}$ & $\mathrm{~d}$ & 13.0 & 11.7 & 10.3 & & 7.8 & 8.8 & \\
\hline Ata2002, TD8b, G-8, 4 & $\mathrm{DI}_{2}$ & $\mathrm{~d}$ & 7.2 & 6.9 & 5.4 & & 4.8 & 4.5 & \\
\hline
\end{tabular}


Table 29

Measurements of the bones of Bison voigtstedtensis from Atapuerca TD8.

\begin{tabular}{|c|c|c|c|c|c|c|c|c|c|}
\hline rib & & DAPhf & DThf & DHF & & & & & \\
\hline Ata06, Td8b, H-3, 13 & $d$ & 19.7 & 30.2 & $>15$ & & & & & \\
\hline humerus & & DAPd & DTd & DTdf & R1 & R2 & R3 & R4 & R5 \\
\hline Ata94, TD8, t35, G-18, 1 & $d$ & -- & -- & -- & -- & -- & -- & -- & -- \\
\hline Ata2002, tD8b, F-9, 10 & $d$ & -- & 84.4 & 82.7 & 52.1 & 43.3 & 47.5 & 36.3 & 37.5 \\
\hline Ata05, TD8b, G-3, 12 & $\mathrm{~s}$ & -- & -- & $\geq 73.7$ & $\approx 48$ & -- & 45.7 & 33.3 & 35.3 \\
\hline radius & & DAPdf & & & & & & & \\
\hline Ata06, Td8b, G-3, 114 & $d$ & 37.8 & & & & & & & \\
\hline ulnar & & DAP & DT & $\mathbf{H}$ & $\mathrm{Ha}$ & & & & \\
\hline Ata04, Td8b, H-6, 8 & $\mathrm{~s}$ & 36.9 & 21.8 & 44.1 & 31.7 & & & & \\
\hline Ata06, TD8b, G-3, 77 & $\mathrm{~s}$ & $\geq 41.3$ & 22.5 & $>36.6$ & 32.2 & & & & \\
\hline Pisiform & & DAP & DTf & $\mathbf{H}$ & Hf & & & & \\
\hline Ata06,TD8b, G-3, 59 & & 28.8 & 13.1 & 25.4 & 19.0 & & & & \\
\hline magnum & & DAP & DT & H & $\mathbf{h}$ & & & & \\
\hline Ata03, TD8, H-4, 1 & $\mathrm{~s}$ & 46.7 & 49.0 & 27.9 & 24.4 & & & & \\
\hline metacarpal V & & DAPp & DTp & $\mathbf{L}$ & & & & & \\
\hline Ata06, Td8b, G-3, 85 & $\mathrm{~s}$ & 14.4 & 11.7 & $>47.6$ & & & & & \\
\hline Cuneiform II+III & & DAP & DT & & & & & & \\
\hline Ata06, TD8b, G-4, 14 & $d$ & 37.6 & 22.8 & & & & & & \\
\hline metapodial & & DTd & $\begin{array}{l}\text { left } \\
\text { DAP }_{\text {IIIIIV }}\end{array}$ & $\begin{array}{l}\text { left } \\
\text { DT }_{\text {IIIIIV }}\end{array}$ & $\begin{array}{l}\text { right } \\
\text { DAP }_{\text {IIIIIV }}\end{array}$ & $\begin{array}{l}\text { right } \\
\mathrm{DT}_{\text {III/IV }}\end{array}$ & & & \\
\hline Ata94, TD8, t28, G-16, 45 & $?$ & & & 32.0 & $>38$ & 32.0 & & & \\
\hline Ata06, Td8b, G-3, 29 & $?$ & & $>33.7$ & 29.5 & & & juv. & & \\
\hline
\end{tabular}


Table 30

Measurements of the phalanges and sesamoids of Bison voigtstedtensis from Atapuerca TD8.

\begin{tabular}{|c|c|c|c|c|c|c|c|}
\hline Phalanx 1 & & DAPp & DAPpf & DTp & L & DAPd & DTd \\
\hline Ata94, TD8, t29, G16, 61 & I & juv & & & & $\approx 24.0$ & $>24.6$ \\
\hline Ata94, TD8, t29, I-16, 64 & $r$ & juv & & & & 21.4 & 25.8 \\
\hline Ata2002, TD8b, G-14, 9 & r & & & & & & \\
\hline Ata06, TD8b, G-3, 58 & $r$ & juv & & & & $\geq 21.3$ & $\geq 24.0$ \\
\hline Ata06, TD8b, G-04, 36 & 1 & 36.6 & 34.9 & 33.8 & 65.7 & 24.0 & 28.8 \\
\hline Ata06, TD8b, G-04, 62 & $r$ & 37.8 & 32.4 & 33.4 & 69.5 & 22.8 & 31.0 \\
\hline Ata06, TD8b, G-04, 119 & 1 & -- & $\geq 31.3$ & $\geq 29.1$ & 70.9 & 23.6 & 30.2 \\
\hline Phalanx 2 & & DAPp & DAPp' & DTp & $\mathbf{L}$ & DAPd & DTd \\
\hline Ata94, TD8, t29, I-16, 39 & 1 & 34.3 & 32.3 & 29.1 & 48.8 & 29.4 & 25.2 \\
\hline Ata2002, TD8b, F-11, 58 & r & 31.8 & 30.9 & 30.9 & 47.1 & $\geq 27.4$ & $\geq 23.3$ \\
\hline Ata06, TD8b, G-04, 38 & 1 & 37.3 & 32.2 & 31.8 & 49.8 & 31.5 & 27.9 \\
\hline Ata06, TD8b, G-04, 61 & $r$ & 36.5 & 32.7 & 32.8 & 51.0 & 31.2 & 29.7 \\
\hline Ata06, TD8b, G-04, 114 & $r$ & -- & -- & 33.0 & -- & -- & -- \\
\hline Phalanx 3 & & DAPp & DAPp' & DTp & L & & \\
\hline Ata04, TD8b, G-6, 4 & $r$ & -- & -- & 26.6 & $>76.7$ & & \\
\hline Ata06, TD8b, G-3, 48 & I & 45.4 & 39.3 & 24.0 & 71.1 & & \\
\hline Ata06, TD8b, G-04, 41 & 1 & 46.5 & 38.6 & 26.8 & 81.2 & & \\
\hline Ata06, TD8b, G-04, 59 & $r$ & 43.1 & 35.3 & 26.2 & 74.3 & & \\
\hline Sesamoid behind Phalanx 1 & & & $\mathbf{L}$ & DT & DAP & DAP' & \\
\hline Ata06, TD8b, G-4, 72 & 1 & abaxial & 20.6 & 14.5 & 21.1 & 20.2 & \\
\hline Ata06, TD8b, G-4, 63 & 1 & axial & 23.8 & 14.6 & 14.9 & 12.9 & \\
\hline Ata06, TD8b, G-4, 74 & r & axial & 23.5 & 15.6 & 15.1 & 13.4 & \\
\hline Ata06, TD8b, G-4, 76 & $\mathrm{r}$ & abaxial & 20.5 & 15.0 & 19.7 & 17.9 & \\
\hline Ata06, TD8b, G-3, 119 & I & abaxial & $\geq 20.6$ & 10.5 & $>18.2$ & 18.2 & \\
\hline Sesamoid behind Phalanx 3 & & $\mathbf{L}$ & DT & DAP & & & \\
\hline Ata06, TD8b, G-4, 37 & I & 14.4 & 24.9 & 12.9 & & & \\
\hline Ata06, TD8b, G-4, 60 & $\mathrm{r}$ & 14.7 & 23.9 & 13.6 & & & \\
\hline
\end{tabular}




\section{Table 31}

The localities discussed in Section 4 on faunal change and in Figure 18, their ages and references. Bibliographic references to the faunas, and, in case material from an locality has been studied by one of us, the acronym of the museum or university where it has been studied. An indication on the age is given, either in ka (kilo annum), Ma (mega annum), or palaeomagenetic chron or subchron, a guide fossil, etc. The method of "dating" is given: AAR = amino acid racemization, $\mathrm{BC}=$ biochronology, $\mathrm{CN}=$ cosmogenic nuclides, $\mathrm{ESR}=$ electron spin resonance, IRSL = infrared stimulated luminescence, $\mathrm{K} / \mathrm{Ar}=$ potassium / argon, $\mathrm{PM}=$ palaemagnetism, $\mathrm{IR}-\mathrm{RF}$ = infrared radiofluorescence, OSL = optically stimulated luminescence, $\mathrm{TL}=$ thermoluminescence, $\mathrm{US}=$ Uranium Series.

\begin{tabular}{|c|c|c|c|}
\hline $\begin{array}{l}\text { locality } \\
\text { Vérteszölös }\end{array}$ & $\begin{array}{l}\text { reference fauna } \\
\text { Jánossy, 1986; HGSB }\end{array}$ & age & reference age \\
\hline Mosbach 2 & Von Koenigswald \& Heinrich, 1999; NMM & BC: Arvicola & Von Koenigswald \& Heinrich, 1999 \\
\hline Hundsheim & $\begin{array}{l}\text { Von Koenigswald \& Heinrich, 1999; NMW } \\
\text { IPUW }\end{array}$ & BC: Arvicola & Von Koenigswald \& Heinrich, 1999 \\
\hline Mauer & $\begin{array}{l}\text { Von Koenigswald \& Heinrich, 1999; } \\
\text { SMNK; GPIRKUH }\end{array}$ & $\begin{array}{l}\text { IR-RF: } 420 \pm 23 \text { to } 607 \pm 55 \mathrm{ka} \text {; } \\
\text { ESR-US: } 388 \pm 29 \text { to } 627+73 /-71 \mathrm{ka} \\
\text { (for the whole sequence) }\end{array}$ & Wagner et al., 2010 \\
\hline Westburry B3-8 & $\begin{array}{l}\text { Bishop, 1982; } \\
\text { Lister et al., 2010; } \\
\text { Breda et al., 2010 }\end{array}$ & BC: Arvicola & Stuart \& Lister, 2001 \\
\hline Pontón de Oliva & Sesé \& Soto, 2000; MNCN & & \\
\hline Soleilhac & Lacombat, 2005; MCP & BC: Arvicola & Roebroeks \& Van Kolfschoten, 1995 \\
\hline Isernia la Pineta & Sala, 1996; IGUF & $\begin{array}{l}>602 \pm 2 \mathrm{ka} ; 610 \pm 10 \mathrm{ka} \\
\text { BC: Arvicola }\end{array}$ & $\begin{array}{l}\text { Coltorti et al., 2005; } \\
\text { Sala, } 1996\end{array}$ \\
\hline Bad Frankenhausen & $\begin{array}{l}\text { R.D. Kahlke, 1995; } \\
\text { Von Koenigswald \& Heinrich, 1999; IQW }\end{array}$ & in lower Elsterian sediments & $\begin{array}{l}\text { R.D. Kahlke, 1995; } \\
\text { Von Koenigswald \& Heinrich, } 1999\end{array}$ \\
\hline Süssenborn & H.D., Kahlke, 1969a; IQW & $\begin{array}{l}\text { BC: Mimomys; } \\
\text { in lower Elsterian sediments }\end{array}$ & H.D., Kahlke, 1969a \\
\hline Stránská Skála Bed 13 & Musil, 1995; MMB & BC: Mimomys, "cold" assciation & Musil, 1995 \\
\hline Prezletice & Fejfar, 1995 & BC: Mimomys, "cold" assciation & \\
\hline Konéprusy C718 & Von Koenigswald \& Heinrich, 1999; NMP & BC: Mimomys, "cold" assciation & Von Koenigswald \& Heinrich, 1999 \\
\hline West Runton & Stuart, 1982; Lister et al., 2010; NHM & BC: Mimomys $\quad$ Stuart, 1982 & \\
\hline Tiraspol & Nikiforova et al., 1971; VMM, GIN & BC: Mimomys & Nikiforova et al., 1971 \\
\hline Pakefield & $\begin{array}{l}\text { Stuart \& Lister, 2001; Lister et al., 2010; } \\
\text { Breda et al., } 2010 \text { NHM }\end{array}$ & BC: Mimomys, OIS 17 & Parfitt et al., 2005 \\
\hline $\begin{array}{l}\text { Voigtstedt } \\
\text { Gombaszög (Gombasek) }\end{array}$ & $\begin{array}{l}\text { H.D. Kahlke, 1965a; IQW, SMS } \\
\text { Kretzoi, } 1938\end{array}$ & BC: Mimomys & H.D. Kahlke, 1965a \\
\hline Stránská Skála Bed C & Musil, 1995; HGSB & BC: Mimomys & Musil, 1995 \\
\hline Würzburg-Schalksberg & Mäuser, 1987 & & \\
\hline Atapuerca TD8 & $\begin{array}{l}\text { Rodríguez, 2011; Van der Made, 2001; } \\
\text { Van der Made, 2001; } \\
\text { García \& Arsuaga, 2001; MNCN, IPHES }\end{array}$ & $\begin{array}{l}\mathrm{PM}:<780 \mathrm{ka} \\
820 \pm 140 \mathrm{ka} \\
602 \pm 52 \mathrm{ka}\end{array}$ & $\begin{array}{l}\text { Parés et al., 2013; } \\
\text { Falguères et al., 1999; } \\
\text { Berger et al., } 2008\end{array}$ \\
\hline Atapuerca TD7 & $\begin{array}{l}\text { Rodríguez, 2011; Van der Made, 2001; } \\
\text { García \& Arsuaga, 2001; IPHES }\end{array}$ & PM: 780 ka in top of unit & Parés et al., 2013 \\
\hline Cueva Victoria & Carbonell et al., 1981; IPS, MAC & PM: >780 ka & \\
\hline Lakhuti 2 & Vangengeim et al., 1988; PIN & PM: >780 ka & \\
\hline Dorn Dürkheim 3 & Franzen et al., 2000; FISF & $\begin{array}{l}\text { PM: >780 ka; } \\
\text { BC: latest Early Pleistocene }\end{array}$ & Franzen et al., 2000 \\
\hline Happisburgh HB3 & Parfitt et al., 2010 & PM: >780 ka & Parfitt et al., 2010 \\
\hline Akhalkalaki & Vekua, 1986; GSM & & \\
\hline Apollonia 1 & $\begin{array}{l}\text { Koufos \& Kostpoulos, 1997; } \\
\text { Kostopoulos, 1997; AUT }\end{array}$ & BC: $0.6-0.9 \mathrm{Ma}$ & Koufos \& Kostpoulos, 1997, fig. 2 \\
\hline St. Prest & Guérin et al., 2003 & $\begin{array}{l}\mathrm{PM}:>780 \mathrm{ka} \\
\mathrm{BC}: \approx 1 \mathrm{Ma}\end{array}$ & Guérin et al., 2003 \\
\hline Atapuerca TD6 & $\begin{array}{l}\text { Rodríguez, 2011; Van der Made, 1999; } \\
\text { García \& Arsuaga, 1999; IPHES }\end{array}$ & PM: 0.936-0.98 Ma & Parés et al., 2013 \\
\hline St. Privat & Lacombat, 2005 & BC: $1.8-1 \mathrm{Ma}$ & Lacombat, 2005 \\
\hline Atapuerca TD4-5 & $\begin{array}{l}\text { Rodríguez, 2011; Van der Made, 2001; } \\
\text { García \& Arsuaga, 2001; IPHES, MB }\end{array}$ & PM: 0.936-0.98 Ma & Parés et al., 2013 \\
\hline Huéscar 1 & Alberdi \& Bonadonna, 1989; MNCN & $\begin{array}{l}\text { PM: normal (Brunhes/Jaramillo); } \\
\text { OSL: 420-570 ka }\end{array}$ & $\begin{array}{l}\text { Gibert \& Scott, } 2009 \\
\text { Demuro et al., in press }\end{array}$ \\
\hline El Chaparral & Giles Pacheco et al., 2011; MHMV & $\mathrm{BC}$ & $\begin{array}{l}\text { Giles Pacheco et al., 2011; } \\
\text { López-García, } 2012\end{array}$ \\
\hline Mosbach 1 & $\begin{array}{l}\text { Von Koenigswald \& Tobien, 1987; } \\
\text { Von Koenigswald \& Heinrich, 1999; NMM }\end{array}$ & PM: Jaramillo & Von Koenigswald \& Tobien, 1987 \\
\hline Vallonnet & Moullé et al., 2006; MPRM & PM: Jaramillo & De Lumley et al., 1988 \\
\hline Untermassfeld & $\begin{array}{l}\text { R.D. Kahlke, 1997, 2001a, 2001b, 2006; } \\
\text { IQW }\end{array}$ & PM: Jaramillo & Wiegank, 1997 \\
\hline Colle Curti & Coltorti et al., 1998 & PM: earliest Jaramillo & t al., 1998 \\
\hline Atapuerca TE9 & $\begin{array}{l}\text { Rodríguez, 2011; Van der Made, 2001; } \\
\text { García \& Arsuaga, 2001; IPHES }\end{array}$ & $\mathrm{CN}: 1220 \pm 140 \mathrm{ka}$ & Carbonell et al., 2008 \\
\hline Atapuerca TE7 & $\begin{array}{l}\text { Rodríguez, 2011; Van der Made, 2001; } \\
\text { García \& Arsuaga, 2001; IPHES }\end{array}$ & CN: $1130 \pm 180 \mathrm{ka}$ & Carbonell et al., 2008 \\
\hline Atapuerca TE7-14 & Rodríguez, 2011; Van der Made, 2001; & PM: reversed, Matuyama & Carbonell et al., 2008 \\
\hline
\end{tabular}




\begin{tabular}{|c|c|}
\hline & \\
\hline \multirow{2}{*}{$\begin{array}{l}\text { Ceyssaguet } \\
\text { Trlica }\end{array}$} & Lacombat, 2005; Guérin \\
\hline & $\begin{array}{l}\text { Crégut-Bonnoure \& Dimitr } \\
\text { Forsten \& Dimitrijevic, } 200 \\
\text { Van der Made \& Dimitrijev }\end{array}$ \\
\hline Sainzelles & Lacombat, 2005 \\
\hline Quibas & Montoya et al., 1999; MNC \\
\hline Fuente Nueva 3 & Toro et al., 2010 \\
\hline Barranco León 5 & Toro et al., 2010 \\
\hline Venta Micena & Agustí, 1987; IPS, MNCN \\
\hline Pirro Nord & De Giuli et al., 1986; IG \\
\hline Aliakhmon q Profil & Steensma, 1988; TUC \\
\hline Kapetianos & Steensma, 1988; TUC \\
\hline Libakos & Steensma, 1988; TUC \\
\hline
\end{tabular}

$\mathrm{K} / \mathrm{Ar}:<1.3 \mathrm{Ma}$

BC: $1.3-1 \mathrm{Ma}$

US/ESR: $1.19 \pm 0.21 \mathrm{Ma}$

BC: $1.2 \mathrm{Ma}$

BC: $1.2 \mathrm{Ma}$;

AAR: $1095 \pm 55 \mathrm{ka}$;

US/ESR: $1.37 \mathrm{Ma}$

BC: $1.3 \mathrm{Ma}$

BC: $\sim 1.15 \mathrm{Ma} /$ Farneta Unit
Kaiser \& Croitor, 2004

Agustí et al., 1987

Montoya et al., 1999

Duval et al., 2012

Agustí et al., 1987

Agustí et al., 1987;

Ortíz et al., 2000;

Duval et al., 2012

Sardella et al., 1998

Steensma, 1998 